\title{
EARNINGS QUALITY, FAMILY INFLUENCE AND CORPORATE GOVERNANCE: EMPIRICAL EVIDENCE FROM MALAYSIA
}

\author{
BY \\ WAN ADIBAH BINTI WAN ISMAIL
}

\begin{abstract}
A thesis
submitted to Victoria University of Wellington in the fulfilment of the requirements for the degree of Doctor of Philosophy
\end{abstract}

Victoria University of Wellington 2011 


\title{
Research Supervisors
}

Professor Tony van Zijl

School of Accounting and Commercial Law, Victoria University of Wellington,

Wellington, New Zealand

\author{
Professor Keitha Dunstan
}

School of Business, Bond University,

Gold Coast, Australia 


\section{Declaration on Sources}

I hereby confirm that the work presented in this thesis is my own and original work that has been carried out through the School of Accounting and Commercial Law, Victoria University of Wellington, during my candidature as a $\mathrm{PhD}$ student. I declare that the material of this thesis has not been submitted either in whole or in part for the award of any other degree or diploma at this or any other university. To the best of my knowledge and belief, it contains no material previously published or written by other persons or institutions except where due reference has been made.

Wan Adibah binti Wan Ismail 


\section{Acknowledgements}

I wish to express my sincerest appreciation to my supervisors, Professor Tony van Zijl and Professor Keitha Dunstan, for their invaluable encouragement, continuous guidance, generous help, and insightful and challenging discussions at many stages of the development of this dissertation.

I appreciate the comments from Michael Bradbury, Peter Clarkson, Stephen Taylor, Binh Srinidhi, and Ferdinand Gul. I am indebted to participants of the Journal of Contemporary Accounting and Economics (JCAE) and Seoul National University Joint Symposium 2010, Accounting and Finance Association of Australia and New Zealand (AFAANZ) Doctoral Consortium 2010, the Quantitative Accounting Research Network (QARS) Symposium 2009 \& 2011 and seminars at the School of Accounting and Commercial Law, Victoria University of Wellington for their useful discussions and constructive criticisms. I also want to acknowledge my debt to faculty members of the School of Accounting and Commercial Law and all colleagues who have contributed in many ways during my doctoral study.

There are three people without whom my participation in a doctoral program could not have been possible. Thanks to my dear husband, Khairul Anuar, for his patience and support. Thanks to my loving parents, Wan Ismail and Haminah, for their constant encouragement and faith in all that I do.

I dedicate this dissertation to my children: Najmi, Ainul and Imran whose continuous and unconditional love helps me go through the process. 


\begin{abstract}
This study investigates whether family ownership and control, and corporate governance are associated with earnings quality, and whether family influence in firms weakens the association between corporate governance and earnings quality. This study uses a panel sample of 527 publicly traded firms over the period 20032008 from the Malaysia Stock Exchange (Bursa Malaysia). Identifying family firms as firms in which family members hold a significant portion of shares and possess control over the board of directors, this study finds that family firms have significantly higher earnings quality. The results remain unchanged, even after using alternative measures of earnings quality and family influence. This study also finds that the earnings quality of firms in Malaysia is positively associated with the size and independence of the audit committee and negatively associated with the size of the board of directors. However, these relationships exist only for nonfamily firms. These results on the corporate governance variables suggest that the effectiveness of corporate governance could be mediated by family influence. Using multivariate regressions that include interaction variables for corporate governance and family firms, the study finds that the relationship between corporate governance and earnings quality is mediated by family ownership and control. The result is consistent with the argument that the monitoring role of corporate governance reduces when there is substantial control by family owners in a firm. Overall, this study concludes that family ownership and control drives higher quality earnings for firms regardless of their corporate governance structure.
\end{abstract}




\section{Table of Contents}

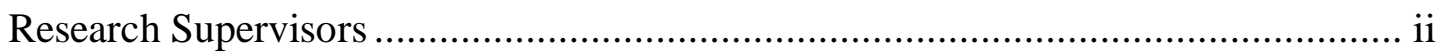

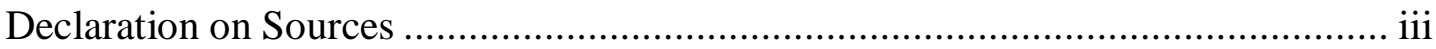

Acknowledgements .......................................................................................... iv

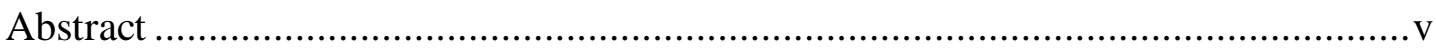

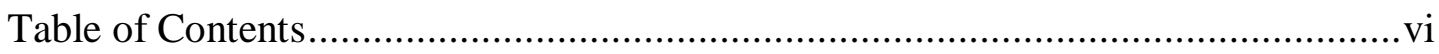

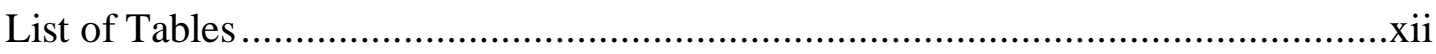

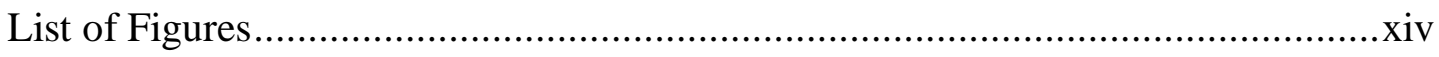

CHAPTER ONE: INTRODUCTION

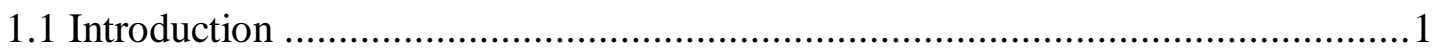

1.2 Research Motivations, Objectives and Questions.................................................

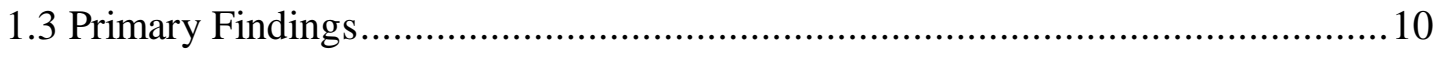

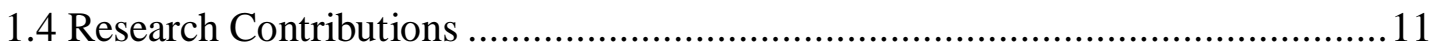

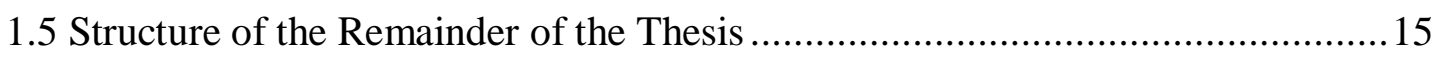

CHAPTER TWO: OVERVIEW OF MALAYSIAN INSTITUTIONAL ENVIRONMENT

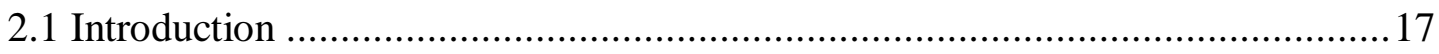

2.2 Background of the Malaysian Economy and Family Businesses ........................17

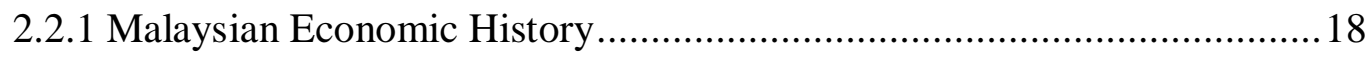

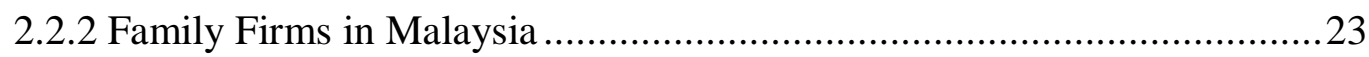

2.3 Corporate Governance in Malaysia.............................................................28

2.3.1 The 1997 Asian Financial Crisis ..............................................................29 
2.3.2 The Introduction of the Malaysian Code on Corporate Governance 31

2.4 Malaysian Financial Reporting Environment.............................................. 37

2.5 Chapter Summary ......................................................................... 41

CHAPTER THREE: PRIOR STUDIES ON EARNINGS QUALITY, FAMILY FIRMS AND CORPORATE GOVERNANCE

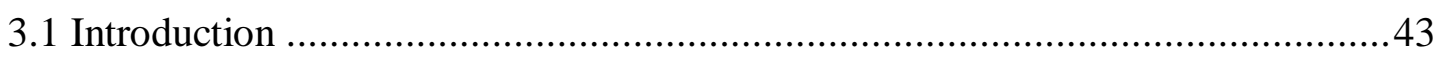

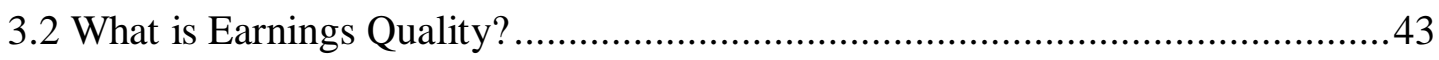

3.2.1 Earnings Quality from Different Perspectives ................................ 44

3.2.2 Earnings Quality Measurements .................................................46

3.2.2.1 Accrual Quality ........................................................... 47

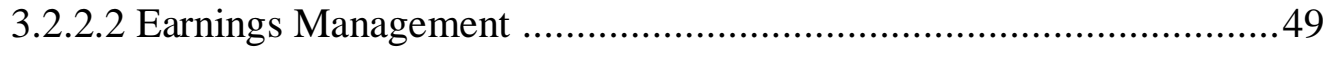

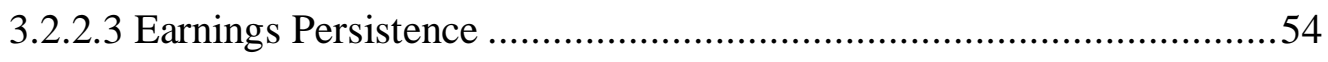

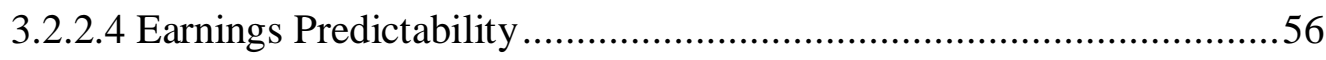

3.2.2.5 Value Relevance ...........................................................5

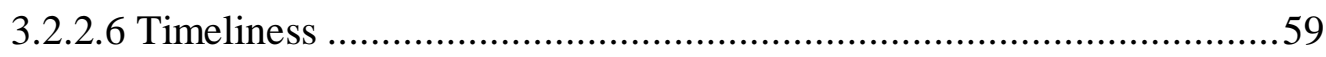

3.2.3 The Importance of High Quality Earnings .......................................60

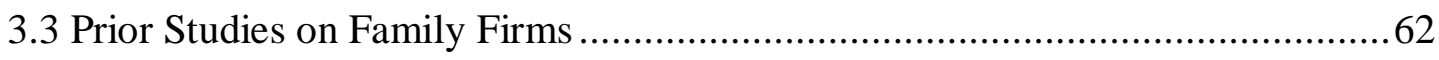

3.3.1 The Special Qualities of Family Firms............................................6 64

3.3.1.1 Altruism in Family Firms .................................................6 65

3.3.1.2 Long-term Horizon of Family Firms ........................................66

3.3.1.3 Lower Monitoring Costs in Family Firms .................................6 68

3.3.2 Disadvantages of Family Firms ....................................................69

3.3.2.1 Divergence of Interests between Family and Minority Owners..........70

3.3.2.2 The Hiring of Family Managers ............................................ 71 
3.3.2.3 Expropriation of Minority Interests ......

3.3.3 Family Firms and Earnings Quality Studies .................................... 73

3.4 Prior Studies of Corporate Governance ..................................................... 81

3.4.1 Definition of Corporate Governance ............................................ 81

3.4.2 Corporate Governance and Earnings Quality .................................. 84

3.4.3 The Mediating Effect of Family Firms on the Corporate

Governance-Earnings Quality Relationship ......................................90

3.5 Summary of the Chapter......................................................................... 93

CHAPTER FOUR: THEORETICAL FRAMEWORK, DEVELOPMENT

OF HYPOTHESES AND RESEARCH METHODOLOGY

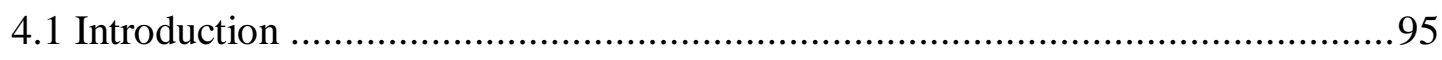

4.2 Theoretical Framework of the Empirical Study ...........................................96

4.3 Development of the Hypotheses ....................................................... 101

4.3.1 Earnings Quality and Family Firms ............................................ 101

4.3.2 Earnings Quality and Corporate Governance ................................... 105

4.3.2.1 Earnings Quality and Audit Committee Size ................................ 106

4.3.2.2 Earnings Quality and Audit Committee Independence ................... 108

4.3.2.3 Earnings Quality and Audit Committee Meeting Frequency ............ 111

4.3.2.4 Earnings Quality and Audit Committee Financial Expertise ............ 112

4.3.2.5 Earnings Quality and Board of Directors Size ............................. 115

4.3.2.6 Earnings Quality and Board Independence............................... 117

4.3.2.7 Earnings Quality and CEO Duality ........................................ 119

4.3.3 Mediating Role of Family Influence on Corporate Governance and Earnings Quality Relationship................................................ 121

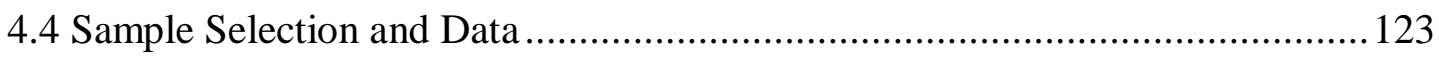




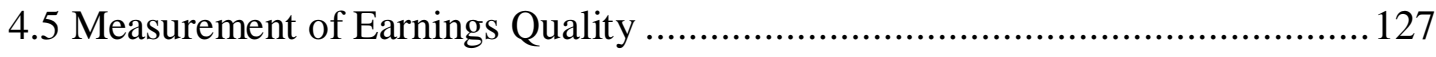

4.6 Family and Nonfamily Firms Identification .................................................... 131

4.7 Measurement of Corporate Governance Variables............................................135

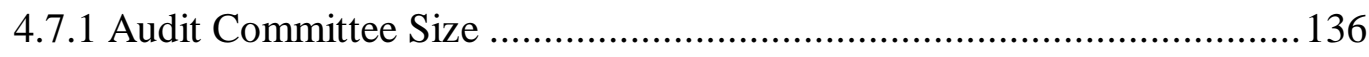

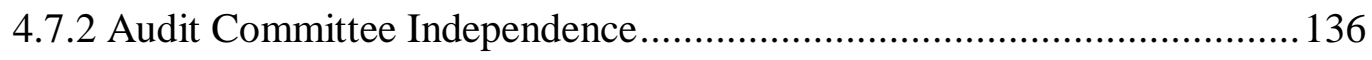

4.7.3 Audit Committee Meeting Frequency ..................................................... 137

4.7.4 Audit Committee Financial Expertise ………………………………..... 138

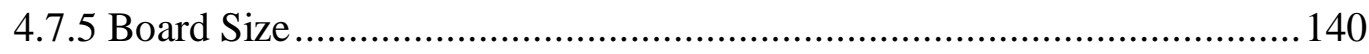

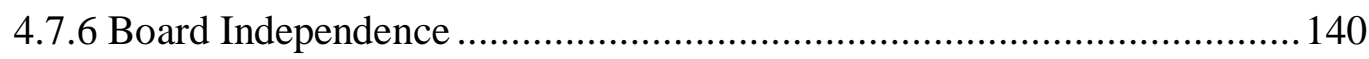

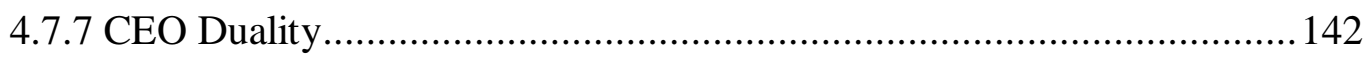

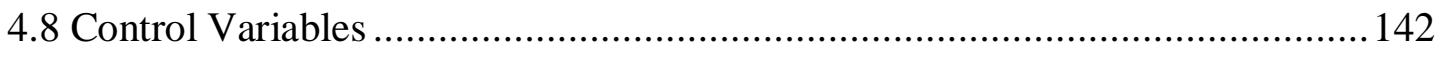

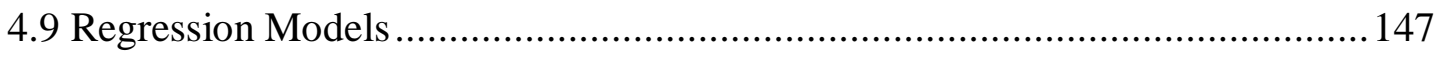

4.9.1 Direct Effect of Family Influence and Corporate Governance Variables on Earnings Quality................................................................ 147

4.9.2 Mitigating Effect of Family Influence on the Relationship between Corporate Governance and Earnings Quality ............................................ 151

4.10 Sensitivity and Robustness Test................................................................. 152

4.10.1 Controlling for Potential Heteroscedasticity Problem............................. 153

4.10.2 Controlling for Potential Time-series Correlations of Pooled Data....... 153

4.10.3 Alternative Measures of Earnings Quality........................................... 155

4.10.4 Alternative Measures of Family Inflluence …………............................ 155

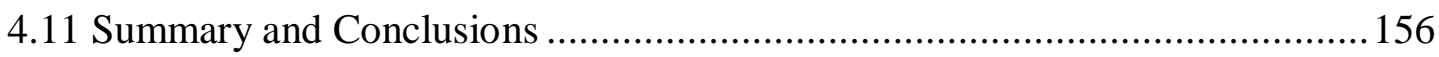

\section{CHAPTER FIVE: RESULTS AND DISCUSSIONS}

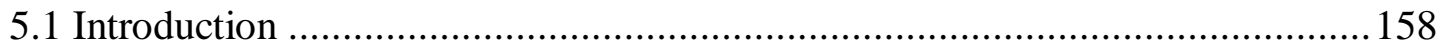

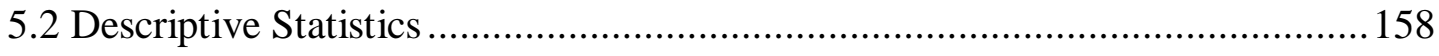


5.4 Multivariate Analysis on the Direct Effect of Family Influence and Corporate

Governance Variables on Earnings Quality............................................... 173

5.5 Multivariate Analysis on the Mitigating Effect of Family Influence on the

Relationship between Corporate Governance and Earnings Quality

5.5.1 Corporate Governance and Earnings Quality Relationship in Nonfamily Firms

5.5.2 Corporate Governance and Earnings Quality Relationship in Family Firms

5.5.3 The Interaction Effect of Family Influence and Corporate Governance on Earnings Quality

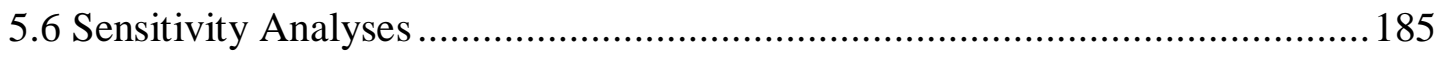

5.6.1 Alternative Measure of Earnings Quality .......................................... 186

5.6.2 Alternative Measures of Family Influence ........................................ 191

5.6.2.1 Measuring Family Influence Based on Family Share

Ownership

5.6.2.2 Measuring Family Influence Based on Family Control of

Board

5.6.2.3 Additional Analysis: Corporate Governance-Earnings Quality

Relationship in Chinese and Malay Family Firms

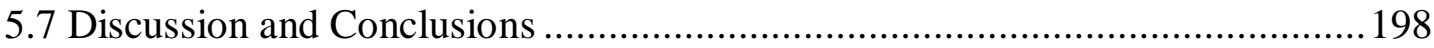

5.7.1 Earnings Quality and Family Firms ................................................. 199

5.7.2 Earnings Quality and Corporate Governance ..................................201

5.7.2.1 Audit Committee Size .............................................................201

5.7.2.2 Audit Committee Independence ..........................................202

5.7.2.3 Audit Committee Meeting Frequency ......................................203

5.7.2.4 Audit Committee Financial Expertise........................................204

5.7.2.5 Board Size ...................................................................... 205

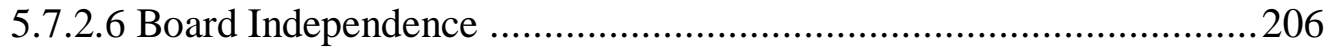


5.7.3 Interaction Effect of Family Influence and Corporate Governance on Earnings Quality 209

5.8 Chapter Summary ..... 210

\section{CHAPTER SIX: SUMMARY AND CONCLUSION}

6.1 Introduction 212

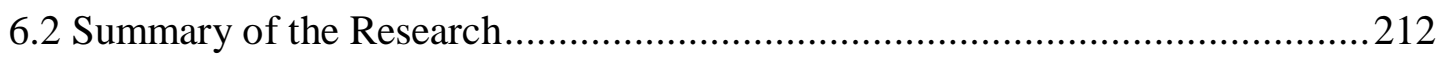

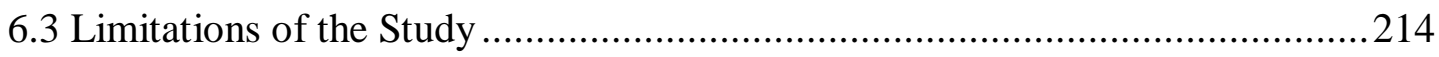

6.4 Contributions and Suggestions for Future Research .......................................215

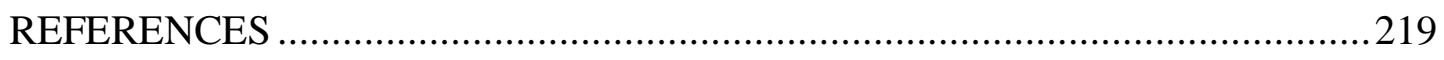

Appendix 1: Compliance with OECD Corporate Governance Principles ................2248

Appendix 2: Definition of Family Firm in Previous Studies ....................................253

Appendix 3: Empirical Studies on Firms Ownership and Accounting Quality .256

Appendix 4: Empirical Studies of the Corporate Governance and Earnings Quality Relation..... 266

Appendix 5: Ticker Code Used to Extract Financial Data from Thompson Financial One Banker Database. 


\section{List of Tables}

Page

Table 2.1: Equity Ownership of Malaysian Publicly Listed

Companies by Ownership Group in 1970-1990

Table 4.1: Derivation of Sample and Industry Category

Table 4.2: Expected Relations between Explanatory Variables and Earnings Quality

Table 5.1: Description of Earnings Quality by Industry and Year

Table 5.2: Description of Family and Nonfamily Firms and Earnings Quality by Industry

Table 5.3: Summary Statistics and Analysis of Mean Differences in Earnings Quality, Corporate Governance and Firm Characteristics between Family and Nonfamily Firms

Table 5.4: Pearson and Spearman Correlation Matrix for Family, Corporate Governance and Control Variables

Table 5.5: Variance Inflation Factors of Variables Used in Regression Tests

Table 5.6: Regression Results of Family Firms and Corporate Governance on Earnings Quality (Earnings Quality $=A Q U A L I T Y$ )

Table 5.7: Regression Results of Corporate Governance on Earnings Quality in Nonfamily Firms (Earnings Quality $=A Q U A L I T Y$ and $F A M I L Y=0$ )

Table 5.8: Regression Results of Corporate Governance on Earnings Quality in Family Firms (Earnings Quality=AQUALITY and FAMILY=1)

Table 5.9: Regression Results of the Effect of Family Firms on the Relationship between Corporate Governance and Earnings Quality (Earnings Quality=AQUALITY)

Table 5.10: Regression Results of Family Firms and Corporate Governance on Earnings Quality (Earnings Quality=AQ2) 
Table 5.11: Regression Results of Corporate Governance on Earnings Quality in Nonfamily Firms (Earnings

Quality $=A Q 2$ and $F A M I L Y=0)$

Table 5.12: Regression Results of Corporate Governance on Earnings Quality in Family Firms (Earnings

Quality $=A Q 2$ and $F A M I L Y=1)$

Table 5.13: Regression Results of the Effect of Family Firms on the Relationship Between Corporate Governance and Earnings Quality (Earnings Quality=AQ2).

Table 5.14: Regression Results of the Effect of Family Share Ownership on the Relationship between Corporate Governance and Earnings Quality (Earnings Quality $=A Q U A L I T Y$ )

Table 5.15: Regression Results of the Effect of Family Control on the Relationship between Corporate Governance and Earnings Quality (Earnings Quality=AQUALITY)

Table 5.16: Regression Results of Corporate Governance on Earnings Quality in Chinese and Malay Family Owned Firms (Earnings Quality=AQUALITY) 


\section{List of Figures}

Page

Figure 2.1: Percentage of Control of Vincent Tan Family over Berjaya Corporation Berhad and Its Publicly Listed Subsidiaries

Figure 2.2: Family Directors in Berjaya Corporation Berhad

Figure 2.3: Excerpt from 2010 Annual Report of IOI Corporation

Berhad

Figure 2.4: Summary Content of the Malaysia Code on Corporate Governance

Figure 2.5: Mandatory Disclosure of Corporate Governance Principles under Bursa Malaysia Listing Requirements

Figure 4.1: Framework of the Study 


\section{CHAPTER ONE: INTRODUCTION}

\subsection{Introduction}

High quality of earnings is especially important in modern corporations, in which equity ownership is separated from control of corporate decisions. The agency theory explained in Jensen and Meckling (1976) and Fama and Jensen (1983b) suggests that conflicts of interest between an agent acting as a representative of a principal might arise in these firms due to divergence of interests and asymmetric information. As agents, the firm managers prepare financial statements to discharge their stewardship; and principals use the information provided, to rewards the agents. However, the use of financial information, such as earnings, in many contractual agreements might provide incentives for earnings management, which results in lower quality of earnings. To mitigate the problem and ensure that alignment of interests exists between the managers and shareholders, significant monitoring mechanisms such as corporate governance are installed within the firm (Shleifer and Vishny, 1986).

According to Jensen and Meckling (1976), if both principal and agents have aligned interests, then there is no conflict of interest and no agency problem. This is obviously true where the principal is the one who manages the firm. Using this argument, research on family firms and earnings quality claims that in family firms, where owners have significant control over the running of the business, agency problems would be reduced and agency cost would be lower. Lower agency problems, as a result of alignment of interests between owners and managers, would 
lead to less incentive for earnings management and therefore higher quality of reported earnings.

However, extant research on firm ownership also suggest that firms in which owners have significant control over management have a different but severe agency problem between controlling shareholders and minority shareholders (La Porta et al., 2000; Morck et al., 1988; Shleifer and Vishny, 1997; Villalonga and Amit, 2006; Wang, 2006). Villalonga and Amit (2006), who refer to the problem between controlling owners and other shareholders as a Type II agency problem ${ }^{1}$, explain that the large shareholder may use its controlling position in the firm to extract private benefits at the expense of the minority shareholders. Thus, family firms, which are typically characterized by having significant controlling owners, might experience higher Type II agency problem, resulting in lower quality of reported earnings.

Prior studies have predominantly focused on the individual effects of various corporate governance instruments on earnings quality without considering how the family structure would affect the success of corporate governance mechanisms in ensuring better quality of earnings. The corporate governance instruments studied include board independence (Klein, 2002), audit committee independence (Klein, 2002; Vafeas, 2005; Yang, 2002), board and audit committee meetings (Vafeas, 2005; Xie, Davidson, and DaDalt, 2003), board and audit committee financial background (Xie, Davidson, and DaDalt, 2003), and CEO-chairman independence

\footnotetext{
${ }^{1}$ Whereas Type I agency problems refers to the agency problem between owners and managers.
} 
(Chau and Gray, 2010; Klein, 2002; Saleh, Iskandar, and Rahmat, 2005). Investigation of the interaction between family control and corporate governance is important, since the presence of strong family influence may reduce the effectiveness, or substitute for a firm's corporate governance mechanisms.

\subsection{Research Motivations, Objectives and Questions}

Wang (2006) investigated the net effect of Type I and Type II agency problems in family firms on the quality of earnings. Despite the argument that the entrenchment effect of controlling shareholders in family firms could lead to poor quality of earnings, Wang (2006) found that earnings quality was higher for family firms. However, Wang (2006) cautions that inferences from this result are applicable only to large publicly traded firms in the United States. The finding that earnings quality is higher in family firms may not hold for other countries, where minority investors' legal protection is weaker (Wang, 2006). This is because the advantage (or drawbacks) for family firms in monitoring earnings quality might depend on the legal protection of minority investors. According to Bebchuk (1999), poor legal protection makes diffusely owned firms unstable, as it allows managerial extraction of private benefits. Consistently, Burkart et al. (2003, p. 2170) claim that when legal protection of outside investors is very good, there is little need for monitoring. On the other hand, when legal protection of minority shareholders is weak, it is very hard to control for managerial expropriation. In this kind of environment, family firms may suffer higher Type II agency cost. From this argument, it is clear that a study examining the quality of earnings of family firms in countries with weak institutional 
environment is very much warranted. In view of that, the first objective of this study is to examine the association between family firms and earnings quality in Malaysia, a country where minority investors' legal protection is weak.

Malaysia presents an ideal setting to address issues related to earnings quality among family firms because of the presence of a large number of family owned and/or controlled entities among publicly listed companies. Apart from the availability of a large population for the sample of family firms, Malaysian family firms have a number of features that makes them very suitable for the purpose of this study. First, in the majority of family firms in Malaysia, the top management and board of directors are dominated by family members, or individuals that are very close to the family. Thus, the controlling family is very much involved with the operations of the business. Second, the ownership of the company is highly concentrated. Most of the family firms are reluctant to allow the holding of a significant proportion of shares by institutional or other outside blockholders. This suggests that in Malaysia, the controlling family tends to maintain control for a long-term period.

Examination of the relationship between earnings quality and family influence in Malaysia is also motivated by the fact that despite a high proportion of family firms in Malaysia, research on family ownership and financial reporting quality in the country is still limited. Analysis of the ten largest Malaysian publicly listed companies by market capitalization by the World Bank (2005) reveals that the five largest shareholders in these companies owned 60.4 percent of the outstanding shares 
and more than half of the voting shares. From the total shares of the ten largest publicly listed companies, 67.2 percent of the shares were in family hands, 37.4 percent had only one dominant shareholder, and 13.4 percent were state controlled. Cheung and Chang (2004), in a study of corporate governance in Asia, show that Malaysia has the second highest degree of family ownership after Hong Kong \& China with 66.7 per cent of total market capitalization controlled by family groups. Given the significant amount of shares held by family members in Malaysia, it is apparent that a study investigating the relationship between family influence and earning quality in Malaysia is highly relevant.

In Malaysia, concerns about the quality of accounting information heightened after the 1997 Asian financial crisis and the outbreak of local accounting scandals such as Technology Resources Industries Berhad, Megan Media Holdings Berhad, Nasiocom Holdings Berhad, GP Ocean, Ocean Capital Ltd., Welli Multi Corporation Berhad, Transmile Group Berhad and Southern Bank Berhad. Through creative accounting and fraud, the management of these firms misled their investors by presenting false and deceptive corporate reports. For example, Technology Resources Industries Bhd (TRI) issued fake invoices totaling nearly RM260 million in 1998 and 1999; and Megan Holdings was found to have misled the Securities Commissions and the stock exchange, Bursa Malaysia (formerly known as the Kuala Lumpur Stock Exchange), by inflating revenue by RM1 billion in its 2006 financial statements. The 2006 unaudited report of Transmile Group Berhad showed an $80 \%$ jump in revenue from RM550 million in 2005 to RM989.2 million, and trade receivables increased 
drastically from RM111 million to RM381 million (Fong, 2007a). The company reported profit of RM75 million and RM158 million for the years 2005 and 2006 respectively. However, the audit revealed that the results should have been net losses of RM370 million and RM126 millions. As a consequence, the company's stock dropped by $47 \%$ from RM14.20 to RM6.70 in June 2007 (Fong, 2007b). PricewaterhouseCoopers reported that Southern Bank Berhad, for the year ended 31 December 2005, had made inappropriate valuations of certain derivative financial instruments, wrongly written back specific provisions of certain foreclosed properties and capitalized certain costs that should be expensed. This misleading accounting resulted in overstated net assets of RM160 million.

The cause of the Asian financial crisis and the many accounting scandals has been attributed to poor corporate governance. The World Bank (1998) points out that weak corporate governance contributed to the Asian financial crisis as it shielded banks, financial institutions and corporations from market discipline. Ineffective boards of directors, weak internal controls, lack of adequate disclosure, lax enforcement to ensure compliance, and poor audits are among the problems that led to the crisis and scandals.

A number of studies have investigated the relationship between earnings quality and corporate governance practices in developed markets such as in the US (e.g. Carcello, Hermanson, Neal, and Riley Jr, 2002), the UK (e.g. Conyon, 1997; Weir et al., 2002) and Australia (Kang, Cheng, and Gray, 2007; Tomasic and Fu, 2006; Williamson- 
Noble and Haynes, 2003). However, very little research has looked at the association between earnings quality and corporate governance mechanisms in emerging capital markets. According to Gibson (2003) and Lins (2003), corporate governance is especially important in emerging markets, such as Malaysia, where the market for corporate control is weak.

Evidence supporting the importance of firm-level corporate governance in countries with poor legal infrastructures and environment is shown in cross-countries studies conducted by Klapper and Love (2004) and Durnev and Kim (2005). Results in Klapper and Love (2004) and Durnev and Kim (2005) support the argument that in these countries, firms could choose to adopt quality firm-level governance to make up for the weak institutional factors. In addition, better corporate governance serves as a signal of firm's willingness to offer better protection for the investors. Corporate governance needs to be effective in these countries for investors to provide the requisite capital. Based on the argument that earnings quality-corporate governance relationship could be more important in emerging markets and the fact that research on earnings quality and corporate governance is still sparse, the second objective of this study is to examine the association between corporate governance and earnings quality in Malaysia.

Previous studies raise concerns regarding the appropriateness of policy that calls for a standard requirement for corporate governance in countries with a concentrated ownership structure, especially in the hands of family members (Cheung and Chan, 
2004; Klein, Shapiro, and Young, 2005; Machuga and Teitel, 2009). According to Klein et al. (2005), similar to the argument that differences in the general governance environment (e.g. competition in product and capital markets, the efficiency of the market for corporate control and managerial labour markets) could affect the efficiency of firms corporate governance in different countries, differences in ownership structures across countries may also interact with the corporate governance mechanisms installed in firms. Similarly, Machuga and Teitel (2009) noted that the prevalence of concentrated family ownership and weak legal environment in Mexico could be the reason of ineffectiveness of the country's code of corporate governance in improving the quality of firms' earnings. Thus, when examining the effectiveness of corporate governance mechanisms in an environment where different ownership structures exists, extra care should be taken to consider the impact of ownership structure.

Agency theory suggests that corporate governance is crucial when there is separation between managers and owners, or when no other control exists to monitor managerial behaviour. As explained by Jensen and Meckling (1976), the shares held by managers help align their interests with those of shareholders. Thus, it could reduce the need for corporate governance. This is supported by a number of studies, which have found that as managerial ownership increases, the quality of earnings increases (e.g. Teshima and Shuto, 2008; Warfield, Wild, and Wild, 1995). 
The Malaysian setting provides the opportunity to extend the literature by examining the relationship between corporate governance and earnings quality in family-owned firms and diffusedly owned firms. The traditional agency-motivated corporate governance mechanisms may not be important in family-owned firms. In these firms, it is usual for a particular family that owns a significant portion of firm's shares to have strong control over management and hold positions on the board. Since the control by the owner (family) already exists in these firms, earnings quality could be high in these firms even if corporate governance is weak. This is based on the alignment effect argument, which suggests that agency conflicts are relatively lower in family controlled firms as compared to diffusedly-owned firms. On the other hand, if the entrenchment effect of the controlling family towards minority interests dominates, earnings quality would be low in family firms even if corporate governance appears to be strong in form. Either way, it is likely that in family controlled firms, the relationship between corporate governance and earnings quality is weak. Therefore, the third objective of this study is to examine whether the existence of family firms mitigates the relationship between corporate governance and earnings quality.

Aligned with research objectives, this study addresses three research questions:

1. What is the relationship between earnings quality and family influence?

2. What is the relationship between earnings quality and corporate governance?

3. Does family influence in firms mitigate the relationship between earnings quality and corporate governance? 


\subsection{Primary Findings}

In general, the results of this study are consistent with the findings of prior studies that recognize family influence (Ali, Chen, and Radhakrishnan, 2007; Sánchez, Alemán, and Martín, 2007; Wang, 2006; Yang, 2010) and corporate governance (Lin, Li, and Yang, 2006; Rahman and Ali, 2006; Saleh, Iskandar, and Rahmat, 2007; Vafeas, 2005; Yang and Krishnan, 2005) as being contributing factors to high quality financial reporting. The results are also in line with prior evidence that family influence in firms mediates the effect of corporate governance on earnings quality (Jaggi and Leung, 2007; Jaggi, Leung, and Gul, 2009; Prencipe and Bar-Yosef, 2011).

Specifically, the results of this study show that firms with significant family ownership or/and control have significantly higher quality of earnings compared to nonfamily firms. The results support the notion that family firms have special features that substitute for the monitoring role of governance over the firm's activities. The higher earnings quality of family firms could be a result of the family firm's altruism and long-term orientation that reduces the incentives for earnings manipulation. The results could also be due to the fact that family firms have lower agency costs and greater expertise relating to the firm's operations.

Consistent with theoretical expectations, the results show that in nonfamily firms, earnings quality, as represented by the quality of its accruals, is positively associated with the size and independence of the audit committee and negatively associated with 
the size of board of directors. However, none of these corporate governance variables are associated with earnings quality in family firms. The results that corporate governance variables are associated with earnings quality only in nonfamily firms, suggest that the effectiveness of corporate governance could be mediated by family influence. The fact that the relationship between corporate governance and earnings quality is mediated by family ownership and control is confirmed using multivariate regressions that include interaction variables for corporate governance and family influence. The results are consistent with the argument that the monitoring role of corporate governance is less important when there is substantial control by family owners. Overall, this study concludes that family ownership and control leads to better quality of earnings in firms regardless of their corporate governance mode.

\subsection{Research Contributions}

The contributions of this thesis are three-fold. First, Malaysia is among the top performing emerging economies. Since independence, the country has recorded average GDP growth of around 6\% per annum. In 2010, the Malaysian economy became the third largest economy in Southeast Asia and the $29^{\text {th }}$ largest economy in the world by purchasing power parity with a gross domestic product of $\$ 412.3$ billion (International Monetary Fund, 2010). In November 2009, The World Bank reported a productivity and investment climate assessment update and concluded that Malaysia's investment climate compared favorably with other countries at similar levels of income (The World Bank, 2009). 
In a report published by PricewaterhouseCoopers on the growth of emerging market economies, Malaysia was marked as a country with a very solid track record of longterm economic growth. The report, prepared by Hawksworth and Cockson (2008) highlights the rapid growth and increasing global significance of emerging economies, including Malaysia. These combined reports clearly demonstrate that Malaysia has gained importance in the world economy. However, the Malaysian economy is still under researched, especially the country's accounting and financial reporting system. This study extends the research on the Malaysian capital market by providing insights into Malaysian financial reporting environment, through the examination of firms' earnings quality.

Second, the Malaysian regulatory bodies intensified their efforts to improve the quality of financial reporting for the country's publicly listed companies. Several initiatives has been undertaken by the government, including the introduction of the Malaysian Code of Corporate Governance, the establishment of the Minority Shareholders Watch Group and the introduction of an IFRS-based set of accounting standards. Thus, studies examining the quality of reported earnings of firms in the country are very timely and warranted. This study provides useful information to the regulators, standard setters and other agencies including the Security Commission, Malaysian Institute of Corporate Governance, Minority Shareholders Watch Group, Malaysia Accounting Standard Board, and the Financial Reporting Foundation. 
Thirdly, this study contributes to the growing body of literature on (i) earnings quality, (ii) firm ownership and control, and (iii) corporate governance. This thesis is among the early studies to examine the differences in earnings quality in family and nonfamily firms outside the scope of developed economies. This study extends Wang's (2006) study on family ownership and earnings quality. Wang (2006) highlights that his findings and inferences apply only to large publicly traded firms in the United States and may not hold outside the US, where minority investors' legal protection is weaker. The current study contributes to the extant study on earnings quality and family ownership by examining the data from an emerging country, Malaysia, where institutional governance is weak. According to Claessens et al. (2002), the effect of large controlling shareholders are difficult to detect using data from developed markets. This is because in a developed market, expropriation of minority interests is limited by strong market controls. The entrenchment effect or the expropriation of minority interests by controlling shareholders would be more apparent in a country with weak institutional arrangements. Therefore, this study provides better evidence of the net effect of managerial entrenchment and the alignment of interest in family firms on earnings quality.

This study is among the earliest that examines the association between the quality of earnings and corporate governance in Malaysia during the period after the implementation of the Malaysian Code of Corporate Governance. The study uses a reasonably large sample size in analysing the relationship between earnings quality and corporate governance. Related studies on corporate governance in Malaysia 
include Saleh, Iskandar and Rahmat (2005) and Rahman and Ali (2006). Specifically, Saleh et al. (2005) focus on the characteristics of board monitoring and the incentives to manage earnings and find that earnings management is negatively associated with managerial ownership, and positively related to the existence of CEO duality in Malaysia. They also find that earnings management is negatively associated with directors having multiple directorships in firms that have negative earnings. However, Saleh et al. (2005) fail to find any association between earnings management and non-executive and independent directors, and size of boards. On the other hand, Rahman and Ali (2006) show that there is a positive association between size of boards and earnings management, but found no evidence of a relationship between earnings management and factors such as board independence, audit committee independence and ethnicity. However, the results of these studies are open for question as they used relatively small samples and were based on short periods ${ }^{2}$. Further, these prior studies measured earnings management using Jones (1991) discretionary accruals model, which has been subject to criticism. Using a relatively big sample size over a longer period, this study provides new and robust evidence on the association between earnings quality and corporate governance mechanisms in Malaysia after the implementation of the Malaysian Code of Corporate Governance.

This study also contributes to the existing literature by examining how corporate governance interacts with family ownership and control to influence the quality of

\footnotetext{
${ }^{2}$ Saleh et al. (2005) used a sample of 561 Malaysian companies in 2001 and Rahman and Ali (2006) used a small sample of 97 Malaysian companies for a two-year period, 2002 and 2003. This study uses 3162 firm-year observations of 527 Malaysian companies over a five-year period from 2003-2007.
} 
earnings. This study is closely related to that of Jaggi, Leung and Gul (2009). Their study examines the effectiveness of independent board of directors in monitoring earnings management in Hong Kong. They find that board independence is effective in reducing earnings management. They also show that the monitoring effectiveness of an independent board is mitigated by family control. While Jaggi et al., (2009) examine the association between board independence and earnings management, this study has a broadened scope by also covering other corporate governance mechanisms and examining earnings quality in terms of the quality of accruals.

Taken as a whole, the evidence presented in this study could be of use to regulators considering corporate governance and accounting standards reforms; investors; minority shareholders and managers who are concerned with the quality of reported earnings; and academics studying earnings quality, family ownership, corporate governance and adoption of new accounting standards.

\subsection{Structure of the Remainder of the Thesis}

The remainder of this thesis is set out as follows. Chapter 2 provides an overview of the Malaysian institutional environment, including the development of the Malaysian capital market, ownership structure of publicly listed firms, corporate governance initiatives and requirements imposed by the government, as well as the adoption of new accounting standards and financial reporting practices. A review of the literature on earnings quality, family ownership and corporate governance is presented in Chapter 3. Chapter 4 provides the theoretical framework, hypotheses and research 
methodology used in this study. The empirical results are reported and discussed in Chapter 5. Chapter 6 presents the conclusions of study, acknowledges the limitations of the study and identifies issues for future research. 


\section{CHAPTER TWO: OVERVIEW OF MALAYSIAN INSTITUTIONAL ENVIRONMENT}

\subsection{Introduction}

This chapter presents an overview of the institutional environment of the Malaysian

economy. It examines the emergence of the Malaysian economy, the development of in corporate governance and the development of the financial reporting environment. Section 2.2 describes the historical predominance of family firms in the Malaysian economy. Section 2.3 discusses the corporate governance of Malaysian publicly listed firms and the initiatives taken to improve the governance of such firms. Section 2.4 describes the financial reporting system in Malaysia, including the legal and regulatory requirements and the other measures taken by the government to promote high quality financial reporting. Finally, Section 2.5 provides a summary of the chapter.

\subsection{Background of the Malaysian Economy and Family Businesses}

Malaysia is one of the emerging Asian economies. Since its independence, Malaysia has recorded excellent economic growth, with average growth in gross domestic product (GDP) of $6.3 \%$ per annum during 1957 to 2010. Before the 1980s, the majority of Malaysian companies were either subsidiaries of foreign multinational corporations or local companies owned by Chinese families. Most of the local 
companies were privately owned and were reluctant to offer their equity to the market for fear of losing control (Ow-Yong and Guan, 2000).

During the early 1980s until the mid 1990s, the country experienced rapid growth, mostly due to the high level of foreign and domestic investment. There was also a large increase in the number of companies listed on the Malaysian capital market, due to the introduction of a second tier market and the government's privatisation programme. Nevertheless, the majority of the companies were still controlled by certain individuals or families with the public as minority shareholders (Saludo, 1999). During 1988 to 1996, the country's economy peaked with average growth in GDP of $9.4 \%$ per annum. Its economic dependence on rubber and tin exports was reduced as the economy was diversified into an emphasis on manufacturing and services. At that time, Malaysia was one of the largest exporters of semiconductor devices, solar panels, and electrical and information technology products (Bureau of East Asian and Pacific Affairs, 2011).

The Malaysian economy however, suffered a sharp reverse during the 1997 financial crisis. Important lessons were learned and since then Malaysia has intensified its efforts to strengthen its capital market.

\subsubsection{Malaysian Economic History}

Prior to independence in 1957 when it was still a British colony, Malaysia's economy was segregated along ethnic lines so as to facilitate administration (Haque, 2003). 
The indigenous people, the Malay ${ }^{3}$, were confined to the paddy fields, Indians worked in the rubber estates and the Chinese were involved in tin mining and business. The British regarded the traditional agricultural sector, in which the majority of Malays were involved as being irrelevant to fostering the British colonial economy. The Malays were thus left where they were (Williams, 2007) while the British instead chose to promote the more lucrative of tin and rubber exports industries using cheap labours from China and India.

The economic policy followed by the British left its mark on Malaysia's current economic structure (Amran and Devi, 2008). The segregation of economic activity along ethnic lines in particular resulted in an economic imbalance between the ethnic groups in the country. According to Johnson and Mitton (2003), although Malays account for the majority of the Malaysia population (about 60\%), business in Malaysia has been historically dominated by the Chinese. The economic disparity between the majority Malay and Chinese finally led to racial riots in 1969.

In order to redress the imbalances that caused the riots, the Malaysian government subsequently introduced the New Economic Policy (NEP) of 1970. This restructured the Malaysian economy over the period 1970-1990 with intent to (1) redistribute corporate entity so that the Malaysian share would rise from $2 \%$ to $30 \%$ for the

\footnotetext{
${ }^{3}$ Malay is also known as the Bumiputera, which literally mean "the son of the soil". Other than Malay, Bumiputera also includes other indigenous groups from East Malaysia.
} 
Bumiputera $^{4}$; and from $35 \%$ to $40 \%$ for other ethnic Malaysian; while the foreign share would fall from $63 \%$ to $30 \%$, (2) to eliminate the close link between race and economic function and restructure employment so that that the Bumiputera share in each sector would reflect their proportion of total population, and (3) to eradicate poverty irrespective of race.

Since the implementation of the NEP, the Bumiputera has received most favoured treatment from the government including priority for government contracts, increased access to capital, opportunities to buy assets that were privatised, and other subsidies (Johnson and Mitton, 2003). In 1975, the government passed the Industrial Coordination Act, which required any non-Bumiputera firm with more than 25 employees and capital and reserves funds of more than RM250,000 to have at least $30 \%$ Bumiputera equity ownership or participation, in order to obtain approval or renewal of business licenses (Lee, 2000). The government has also established several institutions such as the Majlis Amanah Rakyat (MARA), Bumiputera Commercial and Industrial Community, Perbadanan Nasional Berhad (PERNAS), Bank Bumiputera, and the State Economic Development Corporations to provide credit and technical assistance to Malay business entrepreneurs, and requested major business firms and corporations to facilitate the promotion of Malays to higher management positions (Economic Planning Unit, 1991).

\footnotetext{
${ }^{4}$ Bumiputera includes the Malay, Orang Asli (the aborigines) and other indigenous ethnics, such as the indigenous natives from Sabah and Sarawak.
} 
Table 2.1: Equity Ownership of Malaysian Publicly Listed Companies in 1970-1990

\begin{tabular}{lrrrrr}
\hline \multirow{2}{*}{ Ownership Group } & \multicolumn{5}{c}{ Actual Percentage of Equity Ownership } \\
\cline { 2 - 6 } & 1970 & 1975 & 1980 & 1985 & 1990 \\
\hline Bumiputera & $1.90 \%$ & $9.20 \%$ & $12.50 \%$ & $19.10 \%$ & $20.30 \%$ \\
$\quad$ Bumiputera individuals & $*$ & $3.60 \%$ & $5.80 \%$ & $11.70 \%$ & $14.00 \%$ \\
$\quad$ Trust agencies & $*$ & $5.60 \%$ & $6.70 \%$ & $7.40 \%$ & $6.30 \%$ \\
Non-Bumiputera & $37.40 \%$ & $37.50 \%$ & $44.60 \%$ & $54.90 \%$ & $(\mathrm{a}) 46.2 \%$ \\
$\quad$ Chinese & $*$ & $*$ & $*$ & $33.40 \%$ & $44.90 \%$ \\
$\quad$ Indian & $*$ & $*$ & $*$ & $1.20 \%$ & $1.00 \%$ \\
$\quad$ Others & $*$ & $*$ & $*$ & $1.30 \%$ & $0.30 \%$ \\
$\quad$ Nominee companies & $*$ & $*$ & $*$ & $7.20 \%$ & $8.40 \%$ \\
$\quad$ Locally controlled companies & $*$ & $*$ & $*$ & $11.80 \%$ & $* *$ \\
Foreign investors & $60.70 \%$ & $53.30 \%$ & $42.90 \%$ & $26.00 \%$ & $25.10 \%$ \\
\hline Total & $100.00 \%$ & $100.00 \%$ & $100.00 \%$ & $100.00 \%$ & $100.00 \%$ \\
Million Ringgit & 5,289 & 15,084 & 32,420 & 77,964 & 109,800 \\
\hline
\end{tabular}

Note: * indicates unavailable data. ** indicates data that was deleted from statistics. (a)The percentage of equity capital owned by nominee companies in 1990 is not included in the subtotal of non-Bumiputeras shares.

Source: Torii (1997).

The NEP had significant consequences for the ownership structure of Malaysian firms. Under the policy, all publicly listed firms in Malaysia were required to reserve a pre-emptive $30 \%$ equity stake for the Bumiputera (Chu and Cheah, 2006). As showed in Table 2.1, implementation of the NEP resulted in significant changes in the equity ownership of the Bumiputeras, non-Bumiputeras and foreign investors. However, nominee accounts were widely used by many shareholders to hide their identity to avoid the NEP requirement. A report of a study on corporate governance and finance in East Asia by the Asian Development Bank's reveals that in 1997, nominee companies held $45.6 \%$ of the total shares of average non-financial publicly 
listed companies held by the top five shareholders (Capulong, Edwards, Webb, and Zhuang, 2000).

The NEP has also resulted in the establishment of conglomerate firms by family owners and political parties (Searle, 1999), which are mainly Malays. According to Haque (2003), during the mid 1980s, the Malaysian government awarded $61.2 \%$ of privatised assets or companies, amounting to RM8.1 billion, to Malays. This resulted in the emergence of a number of Malay tycoons. Among the Malay business groups, that emerged in the 1980s as a consequence of the economic policy, were the AMDB group, headed by Tan Sri Azman Hashim; the Sapura group, headed by Tan Sri Shamusuddin Abdul Kadir; the Antah group, headed by Tuanku Naquiyuddin and Tuanku Imran of the Negeri Sembilan royal family; and the Melewar group, headed by Tunku Abdullah and Tunku Iskandar of the Negeri Sembilan royal family (Torii, 1997).

After 20 years of the NEP, the Malaysian government introduced the National Development Policy (NDP) ${ }^{5}$. Despite some shift differences in strategy the NDP is also an "ethnicity-oriented" (Torii, 1997). The policy has resulted in considerable involvement of the government in the corporate sector (Tam and Tan, 2007), as a result of which selected companies have been given certain patronage and advantages.

\footnotetext{
${ }^{5}$ The National Development Policy were made effective from 1991 to 2000.
} 
From this historical review of the Malaysian economy, it is important to note that the economy was originally shaped by the British, and was then transformed through the NEP and NDP. The next section provides a discussion on family businesses in Malaysia and their characteristics.

\subsubsection{Family Firms in Malaysia}

Like in many other parts of the world, most of the businesses in Malaysia started as family businesses. In a survey report, Jasani (2002) states that almost all Small and Medium Scale Enterprises (SMEs) in Malaysia were established, managed and funded by families. These businesses not only acquire capital from the founding family, but employ family members and relatives to handle day to day operations. In particular, Jasani (2002) reports that $59 \%$ of the businesses in Malaysia are controlled and owned by the founder and $30 \%$ are passed to the second generation.

Family businesses in Malaysia are not limited to private companies. More than half of the publicly listed companies on Malaysian stock exchange, Bursa Malaysia, are dominated by families (Claessens et al., 2002). Lim (1981) reported that the 100 largest firms in Malaysia have highly concentrated ownership, the majority being owned by families. Specifically, he found that there were 210,103 stockholders in the 62 largest corporations in Malaysia during 1974-1976. However, less than 100 of the stockholders held more than 50 per cent of the shares in these companies (Lim, 1981). Lim (1981) also reports that only a few hundred families own the majority of stocks in Malaysia. These findings are supported by Sieh (1982), who shows that the 
collective holdings of the largest shareholders represented nearly half of the total capital in the 98 largest manufacturing companies. An update by Zhuang (1999) also shows that over the years 1991-1996, 53.3\% of Malaysian companies included in the study had concentrated ownership, with families being the ultimate controlling shareholders. A later study by Claessens et al. (2000) found that $57.5 \%$ and $67.2 \%$ of publicly listed firms in Malaysia, as of the end of fiscal year 1996, were owned by family at the $10 \%$ and $20 \%$ cut off level, respectively.

Family firms, which dominate the majority of publicly listed corporations in Malaysia share some common characteristics (Capulong et al., 2000). Firstly, the firms rest on the financial and human capital of the founding family (McConaughy, 2000). In these firms, the board of directors is often dominated by the controlling interests of families, and the chairman of the board of directors and the chief executive officer are often the same individual or, if different, are from the same family (Zhuang, 1999). The involvement of family members in the firm's management and governing body reflects the family's strong concern over the success of the business. According to Redding (1996), this is due to the fact that the family's prosperity is closely linked to the firms' performance. Secondly, family shareholdings in the firms are usually concentrated. This allows the controlling family to maintain a dominant voice in the company's policies and decisions (Tam and Tan, 2007). Other than being concentrated, the control is also obtained through cross-holdings (Thillainathan, 1998) and interlocking shareholdings (Zhuang, 1999). 
Berjaya Corporation Berhad is an example of family firm in Malaysia. The company is among the main players in the Malaysian stock market with a RM4.63 billion market capitalisation ${ }^{6}$ (Sraa et al., 2011).

Figure 2.1: Percentage of Control of Vincent Tan Family over Berjaya Corporation Berhad and Its Publicly Listed Subsidiaries

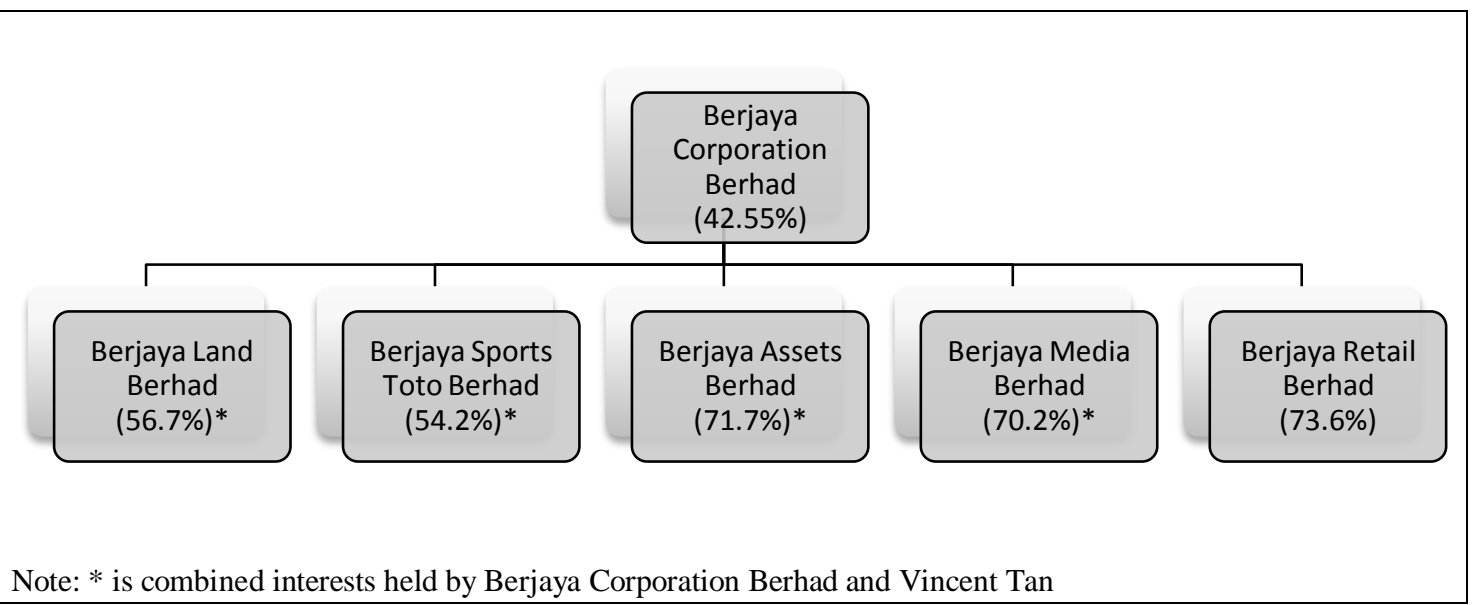

Source: retrieved from Berjaya Corporation Berhad website at www.berjaya.com/corporate-structure.html on 20 June 2011.

Vincent Tan Chee Yioun and his family hold $42.55 \%$ of Berjaya Corporation's total shares including both direct and deemed interests in the company. Through the significant level of control over the shares of Berjaya Corporation, the family also controls five other publicly listed companies (its subsidiaries), namely, Berjaya Land Berhad, Berjaya Sports Toto Berhad, Berjaya Assets Berhad, Berjaya Media Berhad and Berjaya Retail Berhad. Figure 2.1 shows the control of Vincent Tan's family over the five other publicly listed companies in Malaysia through the holding in Berjaya Corporation Berhad.

\footnotetext{
${ }^{6}$ Market capitalization as at 21 January 2011.
} 
Figure 2.2: Family Directors in Berjaya Corporation Berhad

\begin{tabular}{|c|c|c|c|}
\hline $\begin{array}{c}\text { Vincent Tan Chee } \\
\text { Yioun }\end{array}$ & Tan Chee Sing & $\begin{array}{l}\text { Robin Tan Yeong } \\
\text { Ching }\end{array}$ & $\begin{array}{c}\text { Rayvin Tan Yeong } \\
\text { Sheik }\end{array}$ \\
\hline $\begin{array}{l}\text {-The brother of Tan } \\
\text { Chee Sing and father } \\
\text { of Robin Tan Yeong } \\
\text { Ching and Rayvin Tan } \\
\text { Yeong Sheik } \\
\text { - Member of } \\
\text { remuneration } \\
\text { committee } \\
\text {-The founder, } \\
\text { chairman and CEO }\end{array}$ & $\begin{array}{l}\text {-The brother of } \\
\text { Vincent Tan Chee } \\
\text { Yioun and uncle of } \\
\text { Robin Tan Yeong } \\
\text { Ching and Rayvin Tan } \\
\text { Yeong Sheik } \\
\text { - Member of } \\
\text { nomination } \\
\text { committee } \\
\text {-Also holds } \\
\text { directorship in } \\
\text { Berjaya Sports Toto } \\
\text { Berhad and Berjaya } \\
\text { Assets Berhad }\end{array}$ & $\begin{array}{l}\text {-The son of Vincent } \\
\text { Tan Chee Yioun, } \\
\text { nephew of Tan Chee } \\
\text { Sing and brother of } \\
\text { Rayvin Tan Yeong } \\
\text { Sheik } \\
\text { - Member of risk } \\
\text { management } \\
\text { committee } \\
\text {-Also appointed as } \\
\text { the CEO of Berjaya } \\
\text { Sports Toto Berhad } \\
\text { and the chairman of } \\
\text { Berjaya Media } \\
\text { Berhad }\end{array}$ & $\begin{array}{l}\text {-The son of Vincent } \\
\text { Tan Chee Yioun, } \\
\text { nephew of Tan Chee } \\
\text { Sing and brother of } \\
\text { Robin Tan Yeong } \\
\text { Ching } \\
\text {-Also holds } \\
\text { directorship in } \\
\text { Berjaya Sports Toto } \\
\text { Berhad }\end{array}$ \\
\hline
\end{tabular}

Source: Berjaya Corporation Berhad Annual Report 2010

Like most family firms in Malaysia, Vincent Tan's family does not only own a significant proportion of the shares in the public listed companies, but also secures control over the firms by holding important positions in top management and the corporate boards. Vincent Tan, the founder of Berjaya Corporation, serves as the board chairman and chief executive officer. As shown in Figure 2.2, other family members, including his brother and sons also hold appointments as company directors and various positions in the company's publicly listed subsidiaries.

A further example is the IOI Corporation Berhad. The company is mainly controlled by Len Shin Cheng's family through their shares in Progressive Holdings Sdn. Bhd, a privately owned company. In total, the family has at least a $41.10 \%$ direct interest in IOI Corporation Berhad as they own 100\% of Progressive Holdings equity. Specifically, Len Shin Cheng and his wife Hoong May Kuan own 76\%, while his two 
sons; Lee Yeow Chow and Lee Yeow Seng each own 12\% of the private company's total equity (Sraa et al., 2011). Figure 2.3 provides an excerpt from the IOI Corporation Berhad's annual report that hides the actual direct interest of the family members through the incorporation of the private company. Similar to Berjaya Corporation Berhad, four family members hold appointments as the company's directors to protect the interest of the family.

Figure 2.3: Excerpt from 2010 Annual Report of IOI Corporation Berhad

\begin{tabular}{|c|c|c|c|c|}
\hline \multicolumn{5}{|c|}{$\begin{array}{l}\text { SUBSTANTIAL SHAREHOLDERS } \\
\text { (as per Register of Substantial Shareholders) }\end{array}$} \\
\hline \multirow[b]{2}{*}{ NAME OF SHAREHOLDERS } & \multicolumn{4}{|c|}{ NO OF SHARES HELD } \\
\hline & DIRECT & $\%$ & INDIRECT & $\%$ \\
\hline Tan Sri Dato' Len Shin Cheng & $58,684,900$ & 0.92 & $2,630,833,780$ & 41.25 \\
\hline Puan Sri Datin Hoong May Kuan & - & - & $2,689,568,680$ & 42.17 \\
\hline Dato' Lee Yeow Chor & $8,196,400$ & 0.13 & $2,621,527,380$ & 41.10 \\
\hline Lee Yeow Seng & $1,160,000$ & 0.02 & $2,621,527,380$ & 41.10 \\
\hline Progressive Holdings Sdn. Bhd. & $2,621,527,380$ & 41.10 & - & - \\
\hline Employees Provident Fund Board & $721,642,900$ & 11.32 & $90,858,725$ & 1.42 \\
\hline
\end{tabular}

Source: IOI Corporation Berhad Annual Report 2010

The existence of family firms in a developing country like Malaysia can be explained by several factors. According to Burkart et al. (2003), from an economic perspective, family firms exists due to imperfections in the market for managerial talent or the market for corporate control. When the market for managerial talent does not exist, firms may have to depend on successive generations of the founding family to provide for managerial personnel (Bhaumik and Gregoriou, 2010). Likewise, in the absence of a market for corporate control, where there is no prospect of takeovers to credibly threaten the management of poorly performing companies, the convergence 
of management and ownership becomes a second best monitoring solution. Similarly, Holan and Sanz (2006) explain that family ties provide bonds of trust and a sense of common purpose that can substitute for shortcomings in the legal system. In family firms, it is assumed that agency problems are less because the agents and principals are members of the same family. If such problems arise, the family usually has internal mechanisms and solutions to deal with them (Holan and Sanz, 2006). This supports the argument that family firms are more common in countries with a weak capital market because family ownership acts as substitute for legal protections (Burkart et al., 2003). Other than the market imperfections arguments, family firms might be an outcome of altruism, externalities associated with social capital and the high cost of contract enforceability (Bhaumik and Gregoriou, 2010).

This review of family businesses in Malaysia shows that family firms dominate the Malaysian capital market, signaling its importance to the country's economy and growth. The existence of these firms is partly due to the economic policies of British colonial government and the country's national economic policies since independence. The next section focuses on the country's experience during the 1997 Asian economic crisis and its effort to install good corporate governance.

\subsection{Corporate Governance in Malaysia}

The 1997 Asian financial crisis and high-profile corporate scandals in Malaysia have been linked to, or at least exacerbated by, poor corporate governance (Morris, Pham, and Gray, 2011; Rahman, 2006). The crisis and scandals have drawn attention to the 
importance of monitoring and control mechanisms in ensuring proper management of firms' resources and effective protection of shareholder wealth. In an effort to strengthen the corporate governance system of Malaysian companies, the government and its agencies have launched new market regulations, introduced codes of corporate governance and recommended best governance practices, which follow those introduced in developed countries (Rahman, 2006). The assessment of Malaysian corporate governance by the World Bank (2005) shows that major corporate governance reforms have been implemented since 1998. However, the country is still facing some challenges relating to the protection of minority interest and directors accountability.

The extent of compliance of the Malaysian corporate governance framework to date with the OECD corporate governance principles is illustrated in Appendix 1. The following subsections, Section 2.3.1 illustrate the problems faced in the country during the Asian financial crisis that emphasised the need for better corporate governance in Malaysia; while Section 2.3.2 provides the initiatives taken by the government in promoting good corporate governance practices.

\subsubsection{The 1997 Asian Financial Crisis}

In the year 1997, several countries in East Asia, including Malaysia, were hit by a major financial crisis. The crisis originated from international currency speculation, which led to major slumps in exchange rates. It began as a currency crisis in Thailand after the country removed the pegged exchange rate between the Thai baht and the 
U.S. dollar (Morris et al., 2011). The crisis turned into a financial and economic crisis and spread rapidly to other East Asia countries when foreign investors lost confidence and started to pull out their investments, causing the countries' currencies to fall further (Rahman and Haniffa, 2005). By January 1998, the Malaysian Ringgit had depreciated by almost half of its value from RM2.42 in April 1997 to RM4.88 to the U.S dollar, and interests rates climb to more than $12 \%$ per annum. Some of the affected countries received help from the International monetary Fund (IMF) to counter the crisis by injecting funds and making changes to their fiscal and monetary policies. The Malaysian government chose to implement an independent measure by pegging the Ringgit to the U.S. dollar.

The vulnerability of the Malaysian economy to the Thai spill-over was claimed to be due to several reasons. Some argued that the major factor contributing to the crisis was the large proportion of private sector debt (e.g. Suto, 2003; Thomas, 2002). In 1997, Malaysia had a $170 \%$ debt to GDP ratio and a large proportion of it was shortterm corporate borrowings used to cover long-term projects (Low, 2002). Even worse, some of the borrowings were from foreign banks. High interest rates and the significant drop of Malaysian Ringgit at that time resulted in large numbers of nonperforming loans for the local banks, as well as financial hardship for the borrowing companies.

A report by the Asian Development Bank (2000) states that other than the excessive use of unhedged short-term foreign debt, the vulnerability was caused by weaknesses 
in corporate governance and the poor quality of investments. Poor corporate governance had resulted in poor quality of corporate reporting by publicly listed companies. Ineffective board of directors, weak internal controls, poor audits, lack of adequate disclosure and lax legal enforcement are believed to have contributed to the crisis by shielding companies from market discipline and by failing to terminate unprofitable projects, recognise bad loans, restructure or liquidate poorly performing enterprises, and discipline banks (Capulong et al., 2000). Further, the majority of Malaysian companies had concentrated shareholdings, with subsequent potential problems in the protection of minority shareholders (Haniffa and Hudaib, 2006), and lack of an active market for corporate control to discipline managers who were not working towards maximising shareholder value (OECD, 1999).

The financial crisis has resulted in calls for better corporate governance to be installed in Malaysian companies. According to Morris et al. (2011, p. 207),

The crisis was a large and unexpected macroeconomic shock that pushed firms' market values out of equilibrium. The crisis created unforeseen uncertainty about firms' values and the expected level of wealth expropriation by insiders arising from Malaysian firm's pyramid share ownership structures. As a result, investor demand for transparency and corporate governance increased and regulatory reforms to financial reporting and governance were introduced after the crisis.

\subsubsection{The Introduction of the Malaysian Code on Corporate Governance}

Several initiatives were taken by the policy makers and regulators to improve the quality of financial reporting by Malaysian companies. One of the initiatives was to

strengthen the corporate governance of Malaysian public listed companies by 
introducing a code of corporate governance. The Malaysian Code on Corporate Governance was drafted in 1999 and introduced in March 2000. The code was then revised in 2007 to include additional recommendations relating to the boards of directors and audit committees. The code was basically issued to serve as a guideline to enhance corporate governance practices among public listed companies in Malaysia.

Figure 2.4: Summary Content of the Malaysia Code on Corporate Governance

\begin{tabular}{|c|c|c|}
\hline $\begin{array}{c}\text { PART } 1 \\
\text { Broad Principles of Corporate } \\
\text { Governance for Publicly Listed } \\
\text { Companies }\end{array}$ & $\begin{array}{c}\text { PART } 2 \\
\text { Best Practices of Corporate } \\
\text { Governance for Publicly Listed } \\
\text { Companies }\end{array}$ & $\begin{array}{c}\text { PART } 3 \\
\text { Principles and Best Practices } \\
\text { for Other Corporate } \\
\text { Participants }\end{array}$ \\
\hline $\begin{array}{l}\text { - The board of directors } \\
\text { - Board balance } \\
\text { - Supply of information } \\
\text { - Appointment to the board } \\
\text { - Re-election of the board } \\
\text { - Dialogue between companies } \\
\text { and investors } \\
\text { - The annual general meeting } \\
\text { - Internal control } \\
\text { - Financial reporting } \\
\text { - Relationship with auditors } \\
\text { - Level and makeup of directors' } \\
\text { remuneration } \\
\text { - Remuneration procedure } \\
\text { - Disclosure }\end{array}$ & $\begin{array}{l}\text { - Six principal responsibilities of } \\
\text { the board } \\
\text { - Separation between chairman } \\
\text { and chief executive officer } \\
\text { - Board balance } \\
\text { - Board meetings and } \\
\text { procedure } \\
\text { - Supply of information to the } \\
\text { board of directors by company } \\
\text { secretary } \\
\text { - Establishment of board } \\
\text { committees, such as audit } \\
\text { committee, nomination } \\
\text { committee and remuneration } \\
\text { committee } \\
\text { - Relationship of the board to } \\
\text { management } \\
\text { - The audit committee size, } \\
\text { financial literacy, meetings, } \\
\text { duties and responsibilities } \\
\text { - The relationship between the } \\
\text { board and shareholders }\end{array}$ & $\begin{array}{l}\text {-Institutional shareholders' } \\
\text { responsibility to vote } \\
\text { - Constructive communication } \\
\text { between institutional } \\
\text { investors and companies } \\
\text { management and board } \\
\text { - Evaluation of governance } \\
\text { disclosures by institutional } \\
\text { investors } \\
\text {-The role and responsibility of } \\
\text { extenal auditors }\end{array}$ \\
\hline
\end{tabular}

Source: Malaysia Code on Corporate Governance (Revised, 2007)

The Malaysian Code of Corporate governance was based on the recommendations of the Cadbury Report (1992) and the Hampel Report (1998) in the United Kingdom. 
The code sets out the principles and best practices on corporate governance to improve the monitoring function of the board of directors, audit committee, and the external audit. This includes the essential criteria for the structure and operational process of the monitoring units, such as the composition of the board, procedures for recruiting new directors, remuneration of directors, the use of board committees, their mandates and their activities.

As illustrated in Figure 2.4, the Malaysian Code on Corporate Governance consists of three main components. Part 1 sets out broad principles of good corporate governance that is flexible and adaptable to varying circumstances of individual companies. It proposes the application of 13 broad principles that are related to the board of directors, shareholders, internal control, financial reporting, auditors and director's remuneration. Under Bursa Malaysia listing requirements, companies are required to include in their annual report a narrative statement of how they apply the principles to their particular circumstances. Part 2 provides a set of guidelines and best practices to assist companies in adopting adequate corporate governance instruments. It contains 33 provisions that include matters relating to the construction of an effective board, the number of non-executive directors, board structure and procedures, relationship of the board to management, establishment of board committees and the relationship between the board and shareholders. The compliance with best practices in Part 2 is voluntary. However, under Bursa Malaysia listing requirements, companies are required to disclose their level of compliance with best practice and explain any circumstances justifying departure from such best practice in their annual reports. 
Part 3 sets out the principles and best practice for other corporate participants such as investors and auditors with the aim of improving their role in corporate governance. The recommendations in Part 3 are purely voluntary and have no disclosure requirements. In addition to the three main sections in the code, explanatory notes to Part 1, 2 and 3 are provided in Part 4. The section also includes "mere best practices" in addition to the recommendations in earlier sections. The mere best practices are completely voluntary, and companies are not required to state or explain any departure from the recommendations.

Under the Malaysian Code on Corporate Governance, the role, composition and structure of the board of directors are viewed as the most important elements for effective corporate governance. The board is responsible for reviewing and approving a strategic plan and to oversee the business operations, while directly monitoring and evaluating the management's performance and to ensure the integrity of accounting and financial reporting systems. A well balanced and effective board would take the lead role in establishing best corporate governance practice. According to the code, a well- balanced board has a good mixture of executive directors and non-executive directors, including independent directors. The revised code specifically recommends that independent non-executive directors should make up at least one-third of the members of a board. This is to ensure that any decision made by the board is independent and not dominated by an individual or a small group of individuals. In view of that, the code also recommends the separation of responsibilities between the chairman and the CEO. Moreover, the code also specifies that non-executive directors 
should have necessary skills and experience and be a person of calibre and credibility so as to bring independent judgment to the board.

The Malaysian Code on Corporate Governance recommends the establishment of the audit, remuneration, nomination, risk management and corporate governance committees by the board of directors ${ }^{7}$. The nomination committee is responsible for proposing new nominees for the board and assessing performance of the directors on an ongoing basis. It should comprise of non-executive directors, with a majority of independent directors. Under the Bursa Malaysia listing requirements, all directors are subject to retirement and re-election at least once every three years. The audit committee should meet the following requirements; (1) must be composed of not fewer than three members (all must be non-executive directors); (2) a majority of the audit committee members must be independent directors; and (3) at least one member of the audit committee must be a member of the Malaysian Institute of Accountants (MIA) or possesses sufficient accounting experience and qualification, or deemed to be "financially literate". A member of the audit committee is financially literate if he/she has the ability to read and understand financial statements, analyse financial statements and ask pertinent questions about the company's operations against internal controls and risk factors, and understand and interpret the application of approved accounting standards (Bursa Malaysia, 2009).

\footnotetext{
7 The establishment of audit committee was made mandatory for publicly listed companies starting from the year 1994 under Bursa Malaysia listing requirement.
} 
Figure 2.5: Mandatory Disclosure of Corporate Governance Principles under Bursa Malaysia Listing Requirements

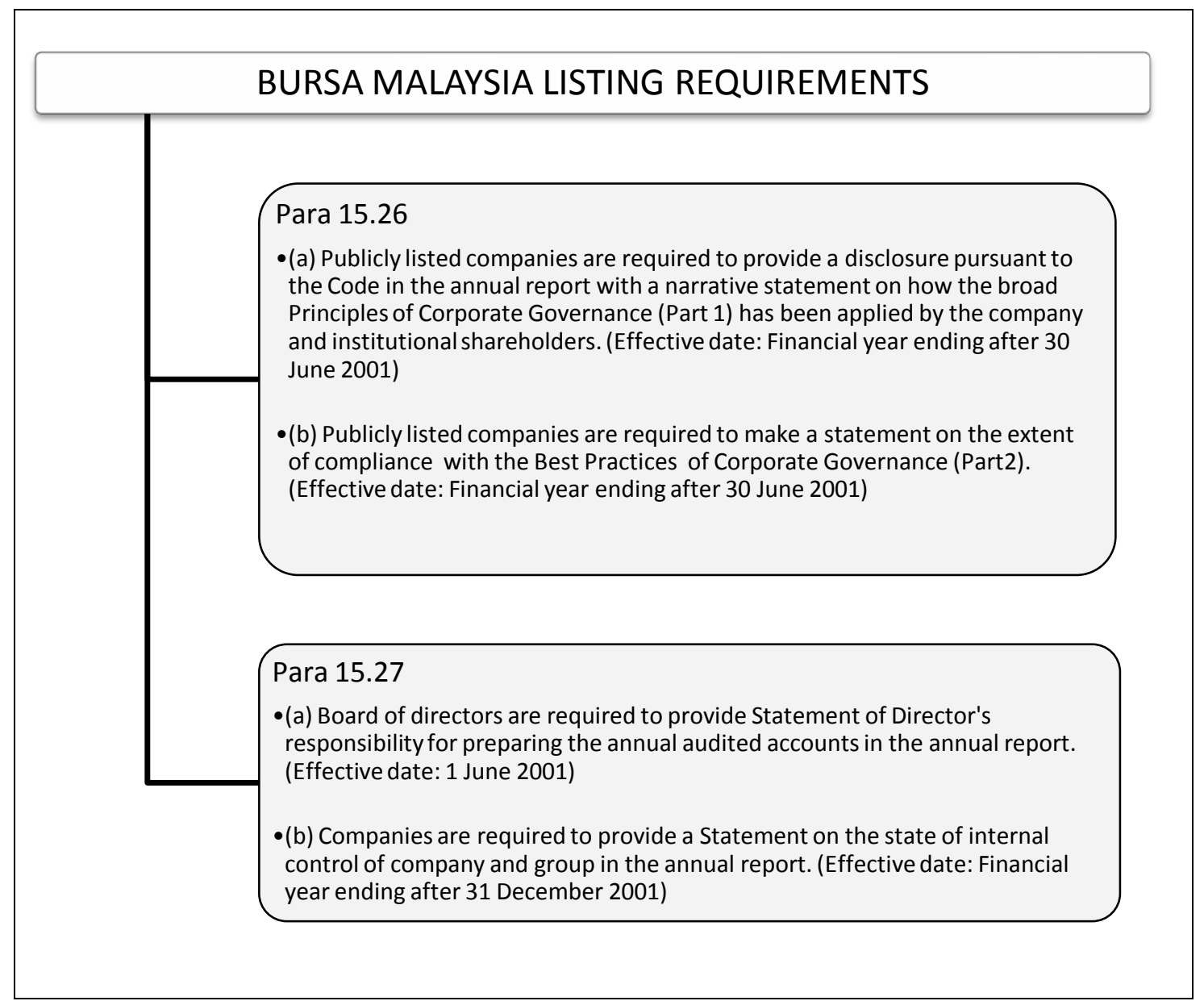

Source: Bursa Malaysia Listing Requirements (2005).

Initially, compliance with the all principles and best practice recommended in the Malaysian Code on Corporate Governance was completely voluntary. Disclosure of compliance with the code was made mandatory by Bursa Malaysia after the revision of its listing requirements in January 2001. As in Figure 2.5, the mandatory disclosure of corporate governance is clearly stated in Paragraph 15.26 and 15.27 of the Bursa Malaysia listing requirements. 
The revised Bursa Malaysia listing requirements are more demanding on public listed companies to enhance Malaysia's corporate governance regime (Yatim, Kent, and Clarkson, 2006). All publicly listed companies are required to include a Statement of Corporate Governance in their annual reports, starting from 1 July 2001. In the statement, the companies are obliged to disclose their level of compliance with the code's recommendation of best practice and explain any departure from the code in their annual reports.

Bursa Malaysia has also taken another initiative to promote good corporate governance practice among publicly listed companies. The stock exchange requires all directors to undergo continuous training, such as the Mandatory Accreditation Program and the Continuing Education Program to improve their capabilities in performing their duties as directors and influence corporate thinking on issues related to corporate governance. The training of directors is set as a condition for continued listing and is required to be disclosed in annual reports, starting from 31 December 2005.

\subsection{Malaysian Financial Reporting Environment}

Accounting and financial reporting practices in Malaysia have evolved and developed in response to the growth in the country's economy. Today, Malaysia has a financial reporting framework that is internationally benchmarked, with adequate qualified accounting professionals and adequate regulatory and governing bodies. Since the 
year 1978, the International Accounting Standards (IAS) issued by the International Accounting Standards Committee (IASC) had become the model for Malaysian accounting standards. In 1996, most IAS standards had either been adopted or were under consideration in Malaysia (Ball et al., 2003). Following the introduction of International Financial Reporting Standards (IFRS) by the IASB, Malaysia has also adopted IFRS, which was made effective from 1 January 2006.

The first formal accounting framework in Malaysia was set up under the Financial Reporting Act 1997 (FRA 1997). The parliamentary act established two bodies, the Malaysian Accounting Standards Board (MASB), which is the accounting standard setter; and the Financial Reporting Foundation (FRF) ${ }^{8}$. Under the FRA 1997, both listed and non-listed companies are legally required to follow MASB standards. In 1998, the requirement to comply with the 'approved accounting standards' as in FRA 1997 was also included as a new provision in the Companies Act 1965 (Amended) ${ }^{9}$.

A number of regulating bodies, including the Securities Commission, Bursa Malaysia, the Central Bank of Malaysia, and the Companies Commission of Malaysia, are in charge of enforcing the compliance with MASB standards. In the case of non-compliance with approved accounting standards, the regulators have the power to direct the company to take the necessary rectifying actions or make

\footnotetext{
${ }^{8}$ FRF is a trustee body who is responsible to oversee MASB's performance, financial and funding arrangements. It acts as a sounding board for the MASB. For instance, the FRF would be the first to review MASB's technical pronouncements before it goes out to the public.

${ }^{9}$ Section 166A of Companies Act 1965.
} 
necessary announcements with respect to the non-compliance and required corrections. For publicly listed companies, there are also financial penalties for such offences.

Through the issuance of rules and policies, the Security Commission (SC) imposes compliance with the accounting standards by publicly listed companies. For example, the SC requires all publicly listed companies to meet the terms in its Corporate Disclosure Policy, which demands that the companies maintain a very high level of disclosure. The SC also requires companies that would like to issue or offer securities to the public to submit the proposed issuance to SC for approval. In the case of failing to submit or submitting false and misleading information to the SC, the company may be penalised for RM3 million or the responsible manager may receive up to 10 years imprisonment. In addition to that, the SC provides timely discussion and review of issues relating to the minimum compliance of accounting standards and other statutory requirements for publicly listed companies. The SC also issued the Post Listing Obligations that requires all publicly listed companies to submit annual and interim corporate reports prepared in accordance with the accounting standards.

The Malaysian stock exchange, Bursa Malaysia, also contributes to the enforcement of accounting standards in Malaysia. Bursa Malaysia monitors the companies traded on the stock exchange through the monitoring of their announcements, market trading activity, the media in general, public complaints, and internal review of documents submitted to Bursa Malaysia. For these companies, compliance with the accounting 
standards is made mandatory through the Bursa Malaysia listing requirements. The listing requirements include the preparation of financial statements in accordance with approved accounting standards and submission of corporate annual reports as well as additional disclosures. Companies that do not meet the terms of the listing requirements may receive warning letters, reprimands, fines for an amount not exceeding RM 1 million, directions for rectification, the non-acceptance of applications or submissions, the imposition of conditions for approval of submissions, suspension of trading and de-listing by Bursa Malaysia. Where listing requirements are breached, the stock exchange may also, on application to the High Court, seek an order requiring the removal of a director of a company and bar him/her from being a director of any other public company.

Compliance with accounting standards in the financial statements of private companies is monitored by a government agency, which is the Companies Commission of Malaysia (CCM). The main responsibility of the CCM is to regulate matters relating to the incorporation of companies, deal with business registration and collect payment for related fees. However, CCM also promotes good ethical conduct amongst directors and managers and provides a facility whereby any corporate information received by the Companies Commission may be analysed and supplied to the public.

For publicly listed banks and financial institutions, in addition to the rules and regulations imposed by Bursa Malaysia, the Central Bank ensures that the financial 
statements comply with the approved accounting standards. In paragraph 11.1 of its Guidelines for Financial Reporting by Banking Institutions, banks and financial institutions are required under section 42 of the Banking and Financial Institutions Act (BAFIA) to publish a complete set of the financial statements (both the institution's and consolidated financial statements) within 14 days of presentation of the financial statements at its general meeting, in at least two local daily newspapers. The Central Bank also provides specimen financial statements and guidelines on financial reporting for banks and financial institutions that deal specifically with nonperforming loans and interest.

In summary, Malaysia has incorporated high quality accounting standards through the adoption of international accounting standards. The financial reporting framework in the country has been strengthened by the establishment of the Malaysian Accounting Standard Board and the Financial Reporting Foundation. The Malaysian government has also, through its agencies, applied a lot of effort to ensure that companies comply with the approved accounting standards in the preparation of their financial statements.

\subsection{Chapter Summary}

This chapter provides the institutional setting for this study, which mainly focuses on the growth of the Malaysian economy, the existence and characteristics of family businesses in Malaysia, development of corporate governance practices and the financial reporting environment for publicly listed companies in the country. It is well 
documented that Malaysia experienced good economic growth until it suffered the financial crisis of 1997. Like other developing countries, corporate shareholdings of Malaysian companies are highly concentrated and mostly dominated by families. The highly concentrated ownership structure, weak legal system, lack of investors' protection and poor quality of financial reporting are among the factors that caused the loss of investors' confidence during the crisis. Since the financial turmoil, the Malaysian government has endeavoured to strengthen and enhance the country's corporate governance framework. Among the initiatives taken was the introduction of the Malaysian Code on Corporate Governance in the year 2000 and revision of the existing listing requirements to mandate disclosure of the company's compliance with the code's recommendations. While the Malaysian Code on Corporate Governance focuses on good corporate governance practice among publicly listed companies, a formal accounting framework was established in 1997 to improve the quality of financial reporting in Malaysia. Statutory bodies such as the Securities Commission, the stock exchange, the Companies Commission and the Central Bank, have all contributed to ensuring that companies comply with the prescribed accounting standards. 


\section{CHAPTER THREE: PRIOR STUDIES ON EARNINGS QUALITY, FAMILY FIRMS AND CORPORATE GOVERNANCE}

\subsection{Introduction}

This study draws and builds on three major streams of accounting research; earnings quality, family businesses and corporate governance. This chapter provides a review of the studies that form the basis for the framing of the hypotheses as well as those studies that provide related evidence. Section 3.2, explains the concept of earnings quality, reviews the measures of earnings quality employed in previous studies, and discusses the importance of having high earnings quality. Section 3.3 provides a review of the previous studies on family firms and the relationship with earnings quality. Section 3.4 defines corporate governance and reviews prior studies on corporate governance and earnings quality. Section 3.5summarises this chapter.

\subsection{What is Earnings Quality?}

The extant literature has not yet come to a unanimous conclusion on what earnings quality is; rather it is viewed as a conceptual term that can be defined from many different perspectives. Academic researchers have introduced and operationalised different dimensions of earnings quality constructs using certain characteristics of earnings and its components. This section describes the definitions from the perspective of standards setters and financial statements users, discusses various measures used in prior studies as proxies for earnings quality, explains the functions 
and limitations associated with each approach and provides examples of the application of each approach in existing studies on earnings quality.

\subsubsection{Earnings Quality from Different Perspectives}

From a decision-usefulness perspective, earnings quality is regarded as being high if the earnings numbers are useful for decision making purposes. Based on this point of view, the notion of earnings quality is defined differently by different users of financial statements. For example, according to Dechow and Schrand (2004), analysts are likely to view earnings to be of high quality when the earnings numbers accurately reflect the company's current operating performance, are good indicators of future operating performance and are a good summary measure for assessing firm value. This is consistent with the objectives of financial analysts, which are to evaluate the performance of the company, assess the extent to which current earnings indicates future performance and determine whether the current stock price reflects intrinsic firm value (Dechow and Schrand, 2004). Investors are likely to have similar objectives. On the other hand, creditors and compensation committees may define high quality earnings as earnings that are easily convertible into cash flows and that reflect managers' real performance.

Financial statement users may also define earnings quality in terms of the 'absence of earnings management'. This is because the intentional manipulation of earnings by managers, within the limits possible in accounting standards, may distort the usefulness of earnings to users. Earnings that are persistent and predictable may not 
be of high quality if it is a result of earnings management. Managers may tend to manage earnings for a number of reasons including those related to capital market motivations, compensation and bonus as well as debt or lending contracts, which will result in low quality of earnings. According to Schipper and Vincent (2003), debt agreements based on low and defective earnings will induce unintended wealth transfers; overstated earnings used as an indicator of managers' performance in compensation contracts will result in overcompensation to managers; and low quality of earnings will provide defective resource allocation signals to investors.

Dechow and Schrand (2004) state that when earnings conform to the spirit and the rules of generally accepted accounting principles, they are of high quality in the eyes of regulators. Earnings should be free from fraud and show a true and fair view of a company's financial performance. However, accounting standard setters are also concerned with the effectiveness of the standards that they have promulgated. By focusing on the usefulness of earnings numbers to financial statements users, standard setters can evaluate quality of earnings prepared under a particular set of accounting standards.

Other than the decision-usefulness context, earnings quality has also been explained in prior research using the economics-based definition of Hicksian income (e.g. Dempster, 2008; Hodge, 2003; Schipper and Vincent, 2003). Shipper and Vincent (2003, p. 98) define earnings quality as "the extent to which reported earnings faithfully represent Hicksian income, where representational faithfulness means 
correspondence or agreement between a measure or description and the phenomenon that it purports to represent". This construct measures the quality of earnings based on its correlation with 'true earnings', which does not depends on accounting recognition rules and the implementation of the accounting rules. 'True earnings' is a neutral and context-free benchmark, yet difficult to assess as Hicksian income is not observable. However, since Hicksian earnings is not observable, the construct is not operational (Schipper and Vincent, 2003).

Yee (2006) explains that earnings quality depends on two main elements, the 'fundamental' earnings and reported earnings. The former is a profitability figure that measures a firm's ability to make future dividend payments, while the latter is an imperfect signal or estimation of 'fundamental' earnings that a firm announces. According to Yee (2006), earnings quality is based on the ability of reported earnings to quickly and precisely reveal a firm's fundamental earnings. The more accurate and timely that reported earnings reflect shocks in the present value of expected future dividends, the higher the quality of earnings.

\subsubsection{Earnings Quality Measurements}

Previous studies define earnings quality through certain characteristics of earnings such as persistence or sustainability, predictive ability, smoothness, conservatism, value-relevance, timeliness, earnings management or earnings manipulation and accrual quality. In general, earnings viewed as being of high quality are those that have a high level of persistence, are more predictable, less volatile, more timely, have 
lower level of earnings management and/or higher accrual quality. The following subsections discuss each of the measures, which have frequently been used in prior studies.

\subsubsection{Accrual Quality}

A seminal study by Dechow and Dichev (2002) introduced a model for earnings quality based on the notion that the function of accruals is to adjust the recognition of cash flows over time, so that it better reflects firm performance. This model relates total current accruals (TCA), measured by changes in working capital, to lagged, current and future cash flows from operations, and has been used in the existing studies as a proxy for earnings quality (Aboody, Hughes, and Liu, 2005; Francis, LaFond, Olsson, and Schipper, 2004; Francis, Schipper, and Vincent, 2003; Myers, Myers, and Omer, 2003; Van der Meulen, Gaeremynck, and Willekens, 2007). In the model, the total current accrual is measured by changes in working capital, since related cash-flow realisations generally occur within one year, which is as follows:

$$
\begin{aligned}
\mathrm{TCA}_{\mathrm{i}, \mathrm{t}} / \mathrm{A}_{\mathrm{i}, \mathrm{t}-1}= & \alpha_{0, \mathrm{i}}+\alpha_{1, \mathrm{i}}\left(\mathrm{CFO}_{\mathrm{i}, \mathrm{t}-1} / \mathrm{A}_{\mathrm{i}, \mathrm{t}}\right)+\alpha_{2, \mathrm{i}}\left(\mathrm{CFO}_{\mathrm{i}, \mathrm{t}} / \mathrm{A}_{\mathrm{i}, \mathrm{t}}\right) \\
& +\alpha_{3, \mathrm{i}}\left(\mathrm{CFO}_{\mathrm{i}, \mathrm{t}+1} / \mathrm{A}_{\mathrm{i}, \mathrm{t}}\right)
\end{aligned}
$$

where:

$\mathrm{TCA}_{\mathrm{i}, \mathrm{t}}=$ firms $i$ 's total current accruals in year $t^{10}$,

$\mathrm{A}_{\mathrm{i}, \mathrm{t}}=$ firms $i$ 's average total assets at the beginning and at the end of fiscal

\footnotetext{
${ }^{10}$ Total current accrual is measured as changes in current assets minus changes in current liabilities, minus changes in cash and plus changes in short term debt (also equivalent to changes in working capital).
} 
year $t$,

$\mathrm{CFO}_{\mathrm{i}, \mathrm{t}}=$ cash flows from operations in year $\mathrm{t}$, calculated as net income before extraordinary items minus total accruals ${ }^{11}$

This model captures both intentional and unintentional accrual estimation error by management, which is the inverse measures of earnings quality (Hermanns, 2006). In other words, the estimation error indirectly measures the extent to which accruals map into cash realisation, where a poor match indicates low quality.

Since the Dechow and Dichev (2002) approach provides a direct link between income and accruals, this model does not have the same problems as the earnings management approach introduced by Jones $(1991)^{12}$, which requires the assumption that certain underlying accounting fundamentals remain constant and unmanipulated. However, Dechow and Dichev (2002) model is also subject to some limitations. Schipper and Vincent (2003) highlight that the model does not distinguish nonmanipulative estimation errors from intentional earnings management and requires the assumption that working capital accruals lag or lead cash receipts by no more than one year.

McNichols (2002) suggests future research should include the change in revenues and property, plant and equipment (PPE) as additional explanatory variables in the

\footnotetext{
${ }^{11}$ Total accrual is measured as changes in current assets minus changes in current liabilities, minus changes in cash, plus changes in short term debt, minus depreciation.

${ }^{12}$ See Section 3.1.2.2 for discussions of Jones (1991) model.
} 
Dechow and Dichev (2002) model, in order to distinguish the unintentional accrual estimation error from those that are intentional. However, inclusion of the new explanatory variables would require the same assumptions as in the Jones (1991) model.

Based on the McNichols (2002) discussion of the Dechow and Dichev (2002) model, Francis et al. (2005) examine the market pricing of accruals quality by investors. Their results show that the market requires less return from firms with better accruals quality than from firms with poor accruals quality.

Doyle, Ge and McVay (2007) examine the relationship between accrual quality and internal controls and find that firms with weak internal control over financial reporting generally have lower accruals quality. This supports their theory that a good internal control system is a key foundation for high quality financial reporting. A later study by Krishnan et al. (2008) suggests that inventory policy affects earnings variability and accruals quality. They find that accruals quality is systematically worse for FIFO firms than for LIFO firms after controlling for correlated omitted variables and known firm attributes.

\subsubsection{Earnings Management}

Davidson, Stickney and Weil (1985) define earnings management as the process of taking deliberate steps, within the constraints of generally accepted accounting 
practice, to bring about a desired level of reported earnings. Similarly, Healy and Wahlen (1999, p. 368) note that:

Earnings management occurs when managers use judgment in financial reporting and in structuring transactions to alter financial reports to either mislead some shareholders about the underlying economic performance of the company, or to influence contractual outcomes that depends on reported accounting numbers.

According to the definitions, it is clear that earnings management is possible because of the discretion available to managers in preparing financial reports. However, it is limited to the boundaries set under a particular set of accounting standards. Thus, any changes in the amount or extent of managerial discretion allowed under the accounting standards may also change the degree of earnings management.

The extant literature on earnings management suggest that earnings management exists due to the important roles and functions played by the reported income or earnings number. As claimed by Vander Bauwhede (2001), managers may be inclined to manage earnings due to the existence of the firm's explicit and implicit contracts, the firm's relation with capital markets, the need for external financing, the political and regulatory environment or several other specific circumstances. For example, earnings numbers are normally included in management compensation and bonus contracts, debts covenants, management buyouts, proxy contests, valuation of initial public offerings (IPOs), labour union negotiations and lobbying on accounting standards and regulations. 
There are numerous situations or incentives that may motivate management to become involved in earnings management. Researchers provide evidence that managers have strong incentives to manage earnings in order to maximise their bonus and compensations (e.g. Gaver and Gaver, 1998; Gaver, Gaver, and Austin, 1995; Healy, 1985; Holthausen, Larcker, and Sloan, 1995; McNichols, Wilson, and DeAngelo, 1988; Shuto, 2007; Steven, 1998; Teshima and Shuto, 2008), to avoid violation of debt covenants or to decrease the cost of debt (e.g. Carlson and Bathala, 1997; DeFond and Jiambalvo, 1994; Jaggi and Lee, 2002; Sweeney, 1994), to circumvent industry and other regulations (e.g. Collins, Shackelford, and Wahlen, 1995; Gill-de-Albornoz and Illueca, 2005; Jones, 1991; Key, 1997; Moyer, 1990; Reza, 2003), to meet the earnings forecasts and targets issued by financial analysts or management (e.g. Dutta and Gigler, 2002; Jaggi, Chin, Lin, and Lee, 2006; Kasznik, 1999; Robb, 1998) and to maximise the proceeds of IPOs (e.g. Ball and Shivakumar, 2008; Chaney and Lewis, 1998; DuCharme, Malatesta, and Sefcik, 2001; Friedlan, 1994; Jaggi et al., 2006; Teoh, Welch, and Wong, 1998).

Previous researchers have established that earnings management can be achieved through several means. The findings of their studies show that using the discretion allowed under accounting standards, managers manipulate earnings by changing firm's depreciation policy including depreciation methods and estimates (Archibald, 1969; Herrmann and Inoue, 1996; Keating and Zimmerman, 2000), adjusting the estimate of the provision for bad debts (McNichols et al., 1988), changing the useful life and/ or residual value of fixed assets through assets revaluations (Easton, Eddey, 
and Harris, 1993; Ervin, Keith, and Tracy, 1998; Whittred and Chan, 1992), classifying gains and losses as extraordinary items (Barnea, Ronen, and Sadan, 1976; Beattie, Brown, Ewers, and John, 1994; Choo and Peter, 1998; Godfrey and Jones, 1999; Jaggi and Baydoun, 2001), not recognising goodwill impairment or not recognising goodwill amortisation and/or write-offs (Beatty and Weber, 2006; Henning, Shaw, and Stock, 2004; Jordan, Clark, and Vann, 2007; Sevin and Schroeder, 2005).

Zheng (2003) claims that the purpose of earnings management, as stated in Healy and Wahlen's (1999) definition indicates that managed earnings are of lower quality than unmanaged earnings. Consistently, previous studies on earnings quality (e.g. Barth, Landsman, and Lang, 2008; Chen, Dhaliwal, and Trombley, 2007; Van Tendeloo and Vanstraelen, 2005) use the term 'earning quality' to denote the absence of earnings management. In addition, Levitt (1998) mentioned that when earnings management is on the rise, the quality of financial reporting is on the decline.

Prior studies have adopted a variety of approaches to measuring the degree of earnings management. Healy (1985), DeAngelo (1986) and Jones (1991) are among the early studies that use abnormal accrual models to detect earnings management. Dechow et al. (1995) explain the development of these early models and give detailed descriptions and provide comparisons between the models. Dechow et al. (1995) found that among Healy (1985), DeAngelo (1986), Jones (1991), modified Jones 
model and industry model, the modified version of Jones (1991) model is the most powerful method of detecting earnings management.

Many of the existing studies refer to Jones (1991) model as a basis for assessment of the level of earnings management. In the Jones (1991) model, the concept of discretionary accruals is used to indicate the quality of earnings. The main idea in the Jones (1991) model is that accruals are likely to be the result of managerial discretion and changes in the firm's economic environment (Hermanns, 2006). Basically, the model estimates firms' abnormal accruals (discretionary) based on certain economic and accounting fundamentals using time-series regression. In the model, Jones relates total accruals to the change in sales and the level of gross property, plant and equipment. The residuals of the model are considered as abnormal or discretionary accruals as they are not explained by the firm's economic conditions. The regression model is as follows:

$\mathrm{TA}_{\mathrm{it}} / \mathrm{A}_{\mathrm{it}-1}=\quad \alpha_{\mathrm{i}}\left(1 / \mathrm{A}_{\mathrm{it}-1}\right)+\beta_{1 \mathrm{i}}\left(\Delta \mathrm{REV}_{\mathrm{it}} / \mathrm{A}_{\mathrm{it}-1}\right)+\beta_{2 \mathrm{i}}\left(\mathrm{PPE}_{\mathrm{it}} / \mathrm{A}_{\mathrm{it}-1}\right)+\varepsilon_{\mathrm{it}}$

Where:

$\mathrm{TA}_{\mathrm{it}}=$ total accruals in year $t$ for firm $i$

$\Delta \mathrm{REV}_{\text {it }}=$ revenues in year $t$ less revenues in year $t-1$ for firm $i$;

$\mathrm{PPE}_{\mathrm{it}}=$ gross property, plant, and equipment in year $t$ for firm $i$;

$\mathrm{A}_{\mathrm{it}-1}=$ total assets in year $t-1$ for firm $i$;

$\varepsilon_{\mathrm{it}} \quad=$ error term in year $t$ for firm $i$ 
According to Jones (1991), revenue is included in the model because it is an objective measure of the firm's operations before managers' manipulations. It is expected that total accruals, which includes changes in accounts receivables, inventories and accounts receivables rely on the extent of changes in revenue (Jones, 1991). While revenues are included to control for firms economic environment, the gross, property and equipment is included to control for the portion of total accruals related to nondiscretionary depreciation expense. The prediction error in the model, $\varepsilon_{\text {it, }}$ measures the level of discretionary accruals.

\subsubsection{Earnings Persistence}

Earnings quality is also defined in previous studies and accounting text books in terms of persistence and sustainability (e.g. Ahmed, Billings, and Morton, 2004; Beneish and Vargus, 2002; Chan, Chan, Jegadeesh, and Lakonishok, 2006; Penman and Zhang, 2002; Richardson, 2003; Richardson, Sloan, Soliman, and Tuna, 2005; Sloan, 1996) Revsine, Collins and Johnson (2002) state that earnings are considered to be of high quality when they are sustainable; and Bodie, Kane and Marcus (2002) defined quality of earnings as the extent to which we might expect the reported level of earnings to be sustained. Focusing on investors' perception of earnings quality, Ayres (1994) notes that one view of earnings quality relates to the overall permanence of earnings. That is, high quality of earnings reflects earnings that can be sustained for a long- period. Similarly, in an empirical study that investigates the joint effects of accounting conservatism and investment on the quality of earnings, Penman and Zhang (2002) define high-quality earnings to be 'sustainable earnings' as often 
referred to in financial analysis. They explain that when an accounting treatment produces unsustainable earnings, it indicates that the earnings figures are of poor quality.

Sloan (1996) leads a stream of studies on earnings persistence that decomposes earnings into two underlying components; accruals and cash flows. He analyses the characteristics of information (about future earnings) contained in those two components of current earnings and investigate the extent to which this information is reflected in stock prices. Sloan (1996) argues that the accrual and cash components of earnings are both relevant to financial statement users, but the former is less reliable, and therefore that the accrual component of earnings is less persistent than the cash flow component. This signifies that there is a negative association between the magnitude of the accrual component of earnings and the persistence of current earnings, and thus earnings quality.

The different persistence of the accrual and cash components of earnings observed in Sloan (1996) inspired subsequent studies to further investigate the implication of accruals for earnings quality (Zheng, 2003). For example, Johnson, Khurana and Reynolds (2002) modified the Sloan (1996) model and introduced a cross-sectional model to examine the impact of audit tenure on the persistence of the accrual component of earnings. 


\subsubsection{Earnings Predictability}

A number of studies measure earnings quality by assessing the ability of earnings to predict future cash flows (Barragato and Markelevich, 2008; Cohen, 2004; Doyle, Lundholm, and Soliman, 2003; Francis et al., 2004; Greenberg, Johnson, and Ramesh, 1986; Van der Meulen et al., 2007). Barragato and Markelevich (2008) define high-quality earnings as an earnings stream that is a better predictor of future operating cash flows. They claim that their definition of earnings quality frequently appears in financial analysts' reports and treatises of financial statement analysis, which supports the view that financial statements should provide information that is useful in assessing the amounts, timing and uncertainties of prospective cash inflows.

Earlier, there were arguments that current earnings may not be a good predictor of future cash flows compared to current cash flows because of the managerial discretion involved in measuring earnings. To clarify this matter, Greenberg et al. (1986) empirically examine whether current earnings or current cash flows are the better predictor of future cash flows. This is done by comparing the coefficient of determination $\left(\mathrm{R}^{2}\right)$ from regressions using either cash flows or earnings as the variable. Their results show higher $\mathrm{R}^{2}$ from the earnings regression, which suggest that current earnings are the better predictor of future cash flows. Similarly, Dechow, Kothari and Watts (1998) report that the forecasting model using current earnings yields smaller variations for forecast errors than the model based on cash flows. On the other hand, Barth, Cram and Nelson (1999) find that disaggregating earnings into 
cash flows and aggregate accruals significantly increases the adjusted $\mathrm{R}^{2}$ for forecasting future cash flows.

Earnings predictability is a similar construct to earnings persistence as both relate to the time-series behavior of earnings. However, Schipper and Vincent (2003) note that there is a possible situation where persistence and predictability may not be consistent. Volatile earnings might be high quality in terms of high persistence (i.e. earnings follows random walk), but low in quality in terms of low predictability (i.e the magnitude of a typical shock to earnings is large).

\subsubsection{Value Relevance}

In much of the accounting research into financial reporting quality, earnings quality is measured by its value-relevance to investors in relation to equity valuation (e.g. Cheng, Hsieh, and Yip, 2007; Lang, Raedy, and Wilson, 2006; Lang, Raedy, and Yetman, 2003; Leuz, Nanda, and Wysocki, 2003). These studies relate earnings directly to stock prices or market returns. The association (the slope coefficient or the explanatory power of the model) between earnings and stock market performance suggests that earnings are both relevant and reliable to investors (Barth, Beaver, and Landsman, 2001). Generally, earnings is considered to be higher in quality if it is more value- relevant. As claimed by Bao and Bao (2004):

Theoretically, if quality of earnings is improved, then the association between firm value and reported earnings should also be improved. If quality of earnings is impaired, then the association between firm value and reported earnings should also be impaired. 
Studies investigating the effect of changes in accounting standards have found that earnings quality is significantly affected by the change indicated in value relevance models. Among others, Cheng et al. (2007) examine whether the choice of accounting treatment of the transition obligation under SFAS106 affects firm value, and whether the quality of earnings was improved after the implementation of the standard. They found that although the total value relevance of both earnings and book value is not affected by the choices allowed under the new accounting standard, earnings quality under the immediate recognition method has been severely undermined by the onetime charge of the transition obligation. The study concludes that, by transforming the accounting standard from the cash basis to accrual basis, SFAS 106 is proved to have resulted in higher quality of earnings.

Another set of studies compares the value relevance of earnings under different accounting standards. For example, Harris, Lang and Moller (1994) compare the associations of earnings reported under foreign and US GAAP. Another study, Joos and Lang (1994) investigates the financial statement effects of differences in accounting measurement practices in France, Germany, and the United Kingdom, and find evidence of significant differences in financial ratios and stock market valuation based on accounting data. Hung (2001) investigates the effect of accrual accounting in different accounting standards on the value relevance of financial statements across 21 countries. Using a sample of 17,743 firm-year observations during the period 1991-1997, she shows that the use of accrual accounting negatively affects the value relevance of accounting performance measures (earnings and ROE) for countries with 
weak shareholder protection. Moreover, for countries with strong shareholder protection, accrual accounting does not negatively affect the value relevance of earnings.

\subsubsection{Timeliness}

Timeliness of earnings is often regarded as one of the characteristics of high quality financial reporting. According to Abdullah (2006) timelier reporting is associated with higher accounting quality as users are able to use the information for such purpose as valuation and evaluation. More timely information (including earnings) is more relevant and thus more useful for financial statements users. Based on this idea, a number of studies use timeliness as one of the qualities of desirable earnings. In Francis et al. (2004), which examines the association between cost of equity and earnings quality, the quality of earnings is represented by seven different attributes including timeliness.

A number of studies have examined factors associated with the timeliness of earnings. Bushman, Chen, Engel and Smith (2004) examine the relationship between governance mechanisms and three different proxies for earnings timeliness. They find evidence of a positive association between timeliness and the proportion of outside board members. Abdullah (2006) study the roles of the composition of board of directors, audit committee and the separation of the roles of the board chairman and the chief executive officer on the timeliness of reporting in Malaysia. Abdullah 
(2006) found that board independence and the separation of the roles of board chairman and CEO significantly are associated with timelier reporting. The study also shows that the 1997 financial crisis had adversely affected the timeliness of reporting, implying that that during difficult periods, companies tend to take a longer time to prepare their audited financial reports.

In Beekes, Pope and Young (2004), timeliness is defined as the length of time taken to reflects information in earnings. Similarly, Raonic, McLeay and Asimakopoulos (2004, p. 120) state that:

Reported earnings may be considered to be timely when they fully reflect the information that has been incorporated by the market in its pricing of a firm's equity. Earnings are less timely if value changes that are recognised by the market in the present period are not incorporated in the accounting computations until sometime in the future.

\subsubsection{The Importance of High Quality Earnings}

Using different approaches to defining earnings quality, the extant literature emphasises that the quality of earnings is very important to users of financial information as well as to practitioners, regulators and accounting researchers. This is because reported earnings are considered to be the premier information in financial statements. According to Salvato and Moores (2010), high quality accounting information on attributes such as earnings is essential for firms to access equity and debt markets. The informative function of earnings means that it is often used as a basis to describe the financial performance of a firm. For example, the earnings numbers and various ratios or metrics derived from it are widely used in 
compensation agreements and debt agreements (Schipper and Vincent, 2003). Earnings are also used by analysts to evaluate firms' previous and current performance and forecast firms' future ability to create additional wealth to shareholders.

According to Schipper and Vincent (2003), the importance of earning quality can be explained from at least two perspectives, the contracting perspective and investment perspective. From the contracting perspective, low quality of earnings may result in unintentional wealth transfers. For instance, firms that rewards managers based on earnings may overcompensate the managers if earnings are overstated. From an investing perspective, poor quality of earnings is problematic as it can mislead investors, resulting in misallocation of resources (Myers et al., 2003; Schipper and Vincent, 2003). High earnings quality would also increase the attractiveness of stocks to outside investors and increase market liquidity (Young and Guenther, 2003), lower cost of debt (Salvato and Moores, 2010), reduce cost of capital (Leuz and Verrecchia, 2000; Salvato and Moores, 2010), and promote more efficient capital allocation (Biddle, Hilary, and Verdi, 2009; Bushman, Piotroski, and Smith, 2011). Thus, it is very important for the reported earnings to be high in quality. 


\subsection{Prior Studies on Family Firms}

Family firms ${ }^{13}$ have received little attention in the academic literature as their predominance seems to be limited to developing countries and privately owned firms (Praet, 2007). Bhattacharya and Ravikumar (2001) state that family businesses are the main form of organisation during the early stage of a country's economic development, and their importance diminishes as the capital market develops. Thus, family firms are seen to be more dominant in developing countries and emerging markets like East Asia. An examination of 2680 companies in East Asia countries by Claessens et al. (2000) reveals that at $20 \%$ cut off level, the majority of the companies in five out of the nine countries surveyed are family controlled. Specifically, they found that $71.5 \%$ of publicly traded companies in Indonesia are under family control, followed by Malaysia (67.2\%), Hong Kong (66.7\%), Thailand (61.6\%) and Singapore (55.4\%). Consistent with Claessens et al. (2000), other studies also shows that the majority of the publicly listed firms in Indonesia (Siregar and Utama, 2008), Malaysia (Tam and Tan, 2007), Hong Kong (Chen and Jaggi, 2000; Jaggi et al., 2009; Mok and Lam, 1992), Thailand (Suehiro and Wailerdsak, 2004), Singapore (Yeung and Soh, 2000) are controlled by families.

While limited research into family firms in developed markets has shown that families own substantial stakes even in the most developed stock markets. In a crosscountry study of ownership structure in 13 Western European countries, Faccio and

\footnotetext{
${ }^{13}$ Previous studies mainly defined family firms based on the percentage of shares owned by family members and/or the existence of family members who are directors. The definitions of family firms employed in previous studies are illustrated in Appendix 2.
} 
Lang (2002) reported that the majority of the publicly listed firms in Austria, Belgium, France, Germany, Italy, Portugal and Spain are family firms. A study by La Porta et al. (1999), that investigates the ownership structure of the publicly traded firms in the 27 wealthiest countries with more than $\$ 500$ million market capitalisation, find that, on average, $30 \%$ of firms in their large firms sample and $45 \%$ of firms in their medium-size sample, based on a $20 \%$ cut-off level, are family controlled. Specifically, they reveal that in the UK (and the US), 40\% (60\%) and 10\% (30\%) of firms in the medium-size sample are family firms based on $20 \%$ (10\%) cutoffs, respectively. Research on large public firms in the US also indicates that founding families have substantial stakes and are represented on the board of directors. For example, Anderson and Reeb (2003a) document that about one-third of the S\&P 500 companies are controlled by founding families and account for 18 percent of the outstanding equity, while Shleifer and Vishny (1986) report that in a sample of 456 of the Fortune500 firms, 149 firms (32\%) have large shareholders and with families represented on the board.

Studies on family firms are based mainly on two theories. The first theory views family firms as a source of comparative advantage that allows the firms to have superior economic outcomes over nonfamily counterparts (Bertrand and Schoar, 2006). The capability of family firms to gain an advantage compared to nonfamily firms is due to the special characteristics and values that they possess (Villalonga and Amit, 2010). The second theory is concerned with family firms having 'private benefits of control'. Based on this theory, the efficiency of family firms is limited 
only to family investors. With the strong control over firms management, the family could seek to maximise value only for the family by exploiting nonfamily investors (Burkart et al., 2003). Managerial decisions in family firms in favour of family members could be at the expense of other shareholders' wealth (Villalonga and Amit, 2010).

With reference to previous studies, the following subsections, Section 3.3.1 and Section 3.3.2, discuss the special qualities of family firms and disadvantages of family firms, respectively. Section 3.3.3, reviews empirical studies on the quality of earnings in family firms.

\subsubsection{The Special Qualities of Family Firms}

It is often contended that family firms have special characteristics that provide them with advantages over diffusedly owned firms (Lee, 2006). Many empirical studies on family firms provide evidence that family firms are associated with better corporate performance (e.g. Allouche, Amann, Jaussaud, and Kurashina, 2008; Anderson and Reeb, 2003a; Andres, 2008; Lee, 2006), higher growth (Lee, 2006) and greater market value (McConaughy, Matthews, and Fialko, 2001; McConaughy, Walker, Henderson Jr, and Mishra, 1998; Villalonga and Amit, 2006). Anderson and Reeb (2003a) explain that this could be due to the reason that the family understands the business better, and the family members that are involved in management view themselves as stewards of the firm. Similarly, McConaughy et al. (1998) and McConaughy et al. (2001) suggest that family relationships improve monitoring that 
is associated with better firm performance. Other than having lower monitoring costs, Davis (1983) highlights that family values such as humanity, trust and altruism, concern over long-term performance (and existence) of the business and greater commitment to quality are among factors that contribute towards higher performance of family firms.

\subsubsection{Altruism in Family Firms}

Family firms are special as they are based on altruism, a trait that positively links the welfare of an individual to the welfare of others (Becker, 1981; Bergstrom, 1989). According to Schulze et al. (2003), altruism provides powerful and self-reinforcing incentives since efforts to maximise one own's benefit would results in satisfying both altruistic (other-regarding) and egoistic (self-regarding) preferences. For example, a parent's welfare is linked to the welfare of their children, and thus any increase in the parent's or children's wealth would be preferred by both parents and children. Likewise, Becker (1981) claims that parents are generous and charitable to their children not only because they love them but also because their own welfare would be negatively affected if they acted in any other way. Schulze et al. (2003), Simon (1993) and Eshel et al. (1998) note that altruism demands parents care for their children. Altruism encourages family members to be kind, thoughtful and considerate of one another. It creates and sustains family bonds and fosters family members' loyalty and commitment to the family and to its prosperity (Ward, 1987).

Stark and Falk (1998) indicate that altruism ensures that family members who work in the family firm believe that they are the firm's owners who have a residual claim 
on the family's estate. The sense of ownership aligns the interests among family agents and lowers the cost of reaching, monitoring, and enforcing agreements. Altruism would also lead to more effective communication and cooperation within the family firm and increase the use of informal agreements (Daily and Dollinger, 1992). The sharing of knowledge among family members and effective communication suggests that information asymmetries among family members would be very low, thus decisions made by family managers are based on adequate and reliable information.

\subsubsection{Long-term Horizon of Family Firms}

Extant literature on family firms also suggests that family owners and managers tend to have a long-term orientation (Allouche et al., 2008; Martínez, Stöhr, and Quiroga, 2007). This is because family firms are concerned with preserving the family inheritance and its transmission to following generations (Casson, 1999). The longterm orientation of family firms engenders organisational qualities that are hard for other firms to replicate (Le Breton-Miller and Miller, 2006); and leads to the implementation of optimal long-term investment policy (James, 1999). With longer investment horizons, family managers suffer less managerial myopia and postpone uncertain short terms earnings so as to harvest long-term profits (Stein, 1989). Family firms also have the potential to perform better as family managers tend to see further ahead than managers in nonfamily firms (Anderson and Reeb, 2003a). 
The long-term nature of a family firm could also strengthen its relationship with the stakeholders, through concerns over the firm's good name and reputation. According to Andres (2008), in family firms, knowledge and experience are usually passed on to descendents to allow them to continue building up trust with employees and develop long-term relationships with suppliers, customers and other external stakeholders. Anderson et al. (2003) suggest that the importance of reputation and long-term orientation allows family firms to enjoy relatively lower cost of debt financing compared to non-family firms. They explain that due to the long-term family commitment, bondholders regard family firms as an organisational structure that decreases the conflicts between shareholders and themselves and consequently better protects their interests.

Martinez et al. (2007) claim that the longer investment perspective in family firms results in the firms' longevity. According to Tapies and Fernandez (2010), longevity of family firms is not only the consequence of long term vision, or the end of process, it is an asset that strengthens the family firm's image, reputation and credibility. Longevity positively affects the family in business, through pride in belonging, pride in the family commitment to its workers and to the business. It creates an emotional link beyond the merely economic ties, strengthens employees' commitment, generates confidence in projects and in people who manage it, and opens the possibility of even more longevity. The longevity of family firms is also related to the incorporation of family values into their corporate culture. A study by Koiranen (2002) explores the corporate values of two family firms in Finland that are over 100 
years old and still entrepreneurially active in business. He finds the top values in these firms that contribute towards their century-old business performance are honesty, credibility, obeying the law, commitment to quality and hard work.

\subsubsection{Lower Monitoring Costs in Family Firms}

Fama and Jensen (1983b) indicate that family firms would be more efficient than firms with dispersed ownership because of lower monitoring costs. According to Schulze et al. (2001), there are at least three reasons why family firms incur significantly lower agency costs compared to other firms. First, owner management in family firms naturally aligns the owners' and managers' interests relating to growth opportunities and risks. The alignment reduces their incentive to be opportunistic, sparing firms the need to maintain "costly mechanisms for separating

the management and control of decisions" (Fama and Jensen, 1983a, p. 332). Second, in family firms, property rights are largely restricted to 'internal decision agents' whose personal involvement assures that managers will not expropriate shareholder wealth through perquisites consumption and misallocation of resources (Fama and Jensen, 1983a, p. 332). Finally, in family firms, shares are held by family members, who have special relations with the managers and thus have an advantage in monitoring and disciplining the managers (Fama and Jensen, 1983b, p. 306).

Andres (2008) notes that large investors such as family shareholders have the incentive and power to decrease agency costs. Unlike small shareholders, large shareholders have a big enough stake that encourages them to spend private resources 
to monitor management. Further, it is much easier for large shareholders to coordinate their actions and put pressure on managers since voting power is not divided into highly segmented group of investors (Andres, 2008, p. 432). In family firms, incentives to monitor managerial actions are particularly strong since families usually have invested most of their private wealth in the company and are not welldiversified. Family shareholders also have an advantage in monitoring as their longterm presence in the firm provides the relevant firm-specific and market knowledge. A family's special technical knowledge concerning a firm's operations may put it in a better position to monitor the firm more effectively (Bartholomeusz and Tanewski, 2006).

Family firms are also likely to have lower agency costs of debt. Jensen and Meckling (1976) and Anderson et al. (2003) explain that diversified shareholders have an incentive to take on risky projects by jeopardising the wealth of bondholders. On the other hand, family members have a basically different risk profile. Due to their undiversified shareholding, long-term orientation and concern for reputation, family shareholders are not only concerned with maximising the value of the equity, but are more likely to maximise the overall value of the company. As a result, the agency costs of debt are more likely to be lower in family firms.

\subsubsection{Disadvantages of Family Firms}

There are also a range of studies that argue that family ownership and control could be detrimental to a firm (Martínez et al., 2007). The characteristics of family 
shareholdings: undiversified and concentrated, favoring of family managers, and the possibility of exploiting of minority shareholders, are among the factors claimed to have negative effects on the performance of family firms. The following subsections explain the disadvantages of family firms widely discussed in the literature.

\subsubsection{Divergence of Interests between Family and Minority Owners}

The concentrated shareholdings in family firms could be detrimental to minority shareholders. This is because large shareholders usually promote their own interests and not those of other shareholders (Andres, 2008). Family owners may use their control rights in order to maximise their own utility, which might come at the expense of other shareholders. As their investments are undiversified, family owners may not be pursuing the same objectives as the minority owners. While minority owners aim to maximise profits and enhance shareholders wealth, family owners may have greater preference for strategies that promote firm growth, technological innovation and firm survival (Martínez et al., 2007).

According to Shleifer and Vishny (1986), large, undiversified shareholders, like families, are costly to firms due to their risk avoidance or aversion. The founding family may unduly reduce the firm's risk through corporate diversification. For example, to reduce risk, founding families may influence the firm's investment decisions by pursuing projects with imperfectly correlated cash flows relative to existing projects (Anderson and Reeb, 2003b). Families may also reduce the risk of default by placing greater reliance on equity financing or, conversely, less than 
optimal use of leverage in the firm's capital structure (Anderson and Reeb, 2003b). The avoidance of or aversion of risk by family managers would impose costs on minority shareholders, whose investments are already diversified.

\subsubsection{The Hiring of Family Managers}

Family firms tend to hire family members to fill management positions, to maintain control over the company's decisions. This could potentially reduced firm's competitive advantage as managerial positions are usually reserved for family members, even when they are not necessarily the most competent managers. Andres (2008) claims that a founder might derive pleasure from seeing his offspring run the company he established. Families also tend to hand over executive positions to family members and thereby restrict the labor pool to a very small group (Andres, 2008). Using Canadian data, Morck et al. (2000) argue that entrepreneurial spirit and expertise are only partly inherited. Supporting the argument, they conclude that descendants gradually regress towards average talent and affect firm performance negatively. In Spain, Gomez- Mejia, Nunez-Nickel, and Gutierrez (2001) find that family firms suffer higher agency costs because the family is unwilling to fire managers who are members of that family. Moreover, family managers may be treated more leniently when they free-ride or shirk (Schulze et al., 2003).

\subsubsection{Expropriation of Minority Interests}

Due to their concentrated ownership, controlling families also have the power and incentive to extract private benefits from the firm (Anderson and Reeb, 2003a; 
Shleifer and Vishny, 1997). The expropriation of the firm's wealth usually occurs through excessive compensation, tunneling of assets, related party transactions, special dividends and transfer pricing. In a case study of a large US firm, DeAngelo and DeAngelo (2000) demonstrate how the controlling family reduced dividends to minority shareholders while paying itself a special dividend. Excessive compensation also occurs through salaries, bonuses and other perquisites for family managers. Bhaumik and Gregoriou (2010) explain that in family firms, asset tunneling typically involves the transfer of a firm's assets to companies fully owned by the families. For example, in Italy, the Tanzi family tunneled out about USD 3 billion from the Parmalat group into other companies that were directly owned by the family (Bhaumik and Gregoriou, 2010).

In China, Jian (2003) found that firms with controlling shareholders are more likely to be involved in related party transactions especially when they have incentives to inflate earnings to avoid being delisted or prior to issuing new equity. Further, controlling families might utilise transfer pricing to shift income to another firm that is fully owned by them, at the expense of the minority shareholders (Ibrahim and Samad, 2010). According to Faccio et al. (2001), the expropriation of wealth by controlling families is usually present in weak financial markets, as the interests of minority shareholders are poorly protected by such legal systems. 


\subsubsection{Family Firms and Earnings Quality Studies}

The question of whether or not family firms have higher earnings quality is ultimately an empirical issue. In addressing the possible associations between the two, existing studies have advanced two alternative arguments. The first argument is based on the 'alignment' hypothesis, which predicts that family firms are positively associated with earnings quality. The controlling family's interests is in the long-term success of the firm, its concerns over the family and firm's reputation and ability to better monitor managers leads to higher quality of accounting, planning and auditing choices (Salvato and Moores, 2010). The second argument is based on the 'entrenchment' hypothesis, which posits that family firms are related to lower quality earnings. This is due to the controlling family's attempts to mislead other stakeholders about the firm's actual financial performance. Family firms may also have the tendency to conceal the extent of wealth expropriation by the founding or controlling families, thus resulting in low quality of accounting, planning and auditing (Salvato and Moores, 2010).

The existing studies on earnings quality and family firms yield mixed evidence ${ }^{14}$. According to Salvato and Moores (2010), most of the supporting evidence for the alignment hypothesis is documented in studies from countries where ownership concentration is low such as in the US (e.g. Ali, Chen, and Radhakrishnan, 2007; Chen, Chen, and Cheng, 2008; Jiraporn and DaDalt, 2009; Wang, 2006). On the other hand, evidence supporting the entrenchment hypothesis is usually reported in studies

\footnotetext{
${ }^{14}$ A summary of research examining firms' ownership (including family) and earnings quality is provided in Appendix 3.
} 
conducted in countries with high ownership concentration or weak legal system (e.g. Choi, Park, and Yoo, 2007; Machuga and Teitel, 2009). However, some of the recent studies show that even in an environment where ownership concentration is high, family firms possess higher quality of earnings compared to nonfamily firms (e.g.Cascino, Pugliese, Mussolino, and Sansone, 2010; Prencipe and Bar-Yosef, 2011; Yang, 2010).

Using data from the S\&P500 companies in the US, Wang (2006) finds that there is a positive and significant relationship between founding family firms and earnings quality. Specifically, the study provides consistent evidence that higher founding family ownership is associated with lower abnormal accruals, greater earnings informativeness and less persistence of transitory loss components in earnings. Wang (2006) concludes that founding family firms are less likely to manage earnings due to fact that founding families have a long-term business horizon, high stake in the firm and great concern for the firm's and family's reputation.

Similar to Wang (2006), Ali et al.’s (2007) examination of S\&P500 companies also reveals that family firms have better quality of earnings compared to nonfamily firms in terms of lower positive discretionary accruals, greater ability of earnings components to predict cash flows, and larger earnings response coefficients (Ali et al., 2007). Based on the results, Ali et al. (2007) conclude that the difference in agency costs across family and non-family firms due to Type I agency problems 
dominates the difference in agency costs across family and non-family firms due to Type II agency problems.

A similar recent study using S\&P 500 companies by Jiraporn and Dadalt (2009) confirms the Wang (2006) and Ali et al. (2007) findings that family firms are less likely to manage earnings than nonfamily firms. Jiraporn and Dadalt (2009) show that the level of abnormal accruals is approximately a third lower for family controlled firms than for their nonfamily counterparts.

Consistent with the studies in the United States, Sánchez et al. (2007) document that the quality of earnings is higher in family firms compared to non-family firms in Spain. Specifically, their results show that family firms have lower discretionary accruals and greater predictability of future cash flows. This supports the argument that family firms are considered by the family to be an asset to be passed to the heirs. Sanchez et al. (2007) conclude that the positive impact of family control on earnings quality persists even in a context where a few shareholders have a high proportion of the voting rights.

In Korea, Jung and Kwon (2002) examine the dominant role of the owner-largest shareholders, which are typically a founder or his immediate family. The study found a positive relationship between the owner-largest shareholders and earnings informativeness, supporting the convergence of interest and alignment hypothesis. 
In Italy, Cascino et al. (2010) found that accounting quality is systematically related to the family firm status being different across family and nonfamily firms. Their results indicate that family firms convey financial information of higher quality than that provide by their nonfamily peers. Specifically, family firms show higher quality of accruals, more persistent, predictable, smoother and value-relevant and timely earnings, relative to nonfamily firms. Cascino et al.'s (2010) result is consistent with an earlier examination by Prencipe, Markarian and Pozza (2008) on the income smoothing incentives of family firms in Italy. Focusing on R\&D costs capitalisation, Prencipe et al. (2008) show that family firms have less incentive to smooth income as they are less sensitive than nonfamily firms to the short term fluctuations of the market. The result supports the argument that the main goal of family firms is to ensure the long-term survival of the firm rather than to maximise short-term shareholders wealth.

An examination of firms' voluntary disclosure in the United States reveals consistent findings. Chen, Chen, and Cheng (2008) find that family-controlled firms are more likely to issue bad news earnings warnings relative to nonfamily firms. The higher likelihood of bad earnings warnings are consistent with family owners being more concerned with the litigation-related and reputation costs of withholding bad news.

In the same vein, Claessens et al. (2002) investigate the effect of large shareholdings on firm value in eight East Asian economies and find that concentrated ownership in the hands of family controlled firms is associated with a higher market-to-book ratio. 
However, they also find that the wedge between control and ownership is associated with value discounts for family-controlled firms. The wedge between control and ownership in family firms allows the family managers to divert benefits to themselves, thus resulting in lower firm value (Claessens et al., 2002). This finding suggest that in so far as the controlling family has equal degrees of ownership and control, family firms are associated with higher firm valuation. Nevertheless, firm value decreases when there is a wedge, which is the difference between ownership (cash flow rights) and control (voting rights).

A recent study on family firms and earnings management of companies listed on the Taiwan Stock Exchange provides mixed findings. Yang (2010) suggests that the level of insider ownership and appointment of a family CEO plays an important role in family firms (Yang, 2010). Specifically, the study finds that in family firms, the higher the level of shares owned by insiders such as top officers, nonexecutive directors and large shareholders; the greater the extent of earnings management. The result that greater insider ownership is associated with low earnings quality supports the entrenchment effect argument. On the other hand, Yang (2010) also documents that the family CEOs have a lower tendency to manage earnings relative to nonfamily CEOs, suggesting that the involvement of family members as the CEO in family firms reduces earnings management and enhanced monitoring. The results indicate a possibility that the involvement of family firms in earnings management practices might not be due to the influence of the controlling family. The level of shares of the 
insiders including the managers and nonexecutive directors could be the contributing factor to the entrenchment effect found in the study.

Evidence of the family entrenchment effect is documented in Machuga and Teitel (2009) and Choi, Park and Yoo (2007). Using a sample of 34 Mexican Bolso firms, Machuga and Teitel (2009) report that firms, which do not have concentrated family ownership, have greater increases in earnings quality in terms of lesser income smoothing, more timely loss recognition and lower conditional accruals. They claim that their results support the theory that the interactions between corporate governance mechanisms and the external market and legal environment cause family ownership to be associated with lower quality earnings. Similarly, using a sample from Korea, Choi et al. (2007) found that firms with 'chaebol' or family control in the board of directors report significantly lower performance. Choi et al. (2007) state that even though family founders provide the initial entrepreneurial contribution, keeping firms ownership and management in the hand of a family creates more costs than benefits.

A related study by Zhao and Millet-Ryes (2007) that investigates how family and bank ownership affect the accounting information content of French firms finds that in family firms the value relevance of book value is higher than the value relevance of earnings. They suggest that their finding is attributed to the lack of incentive to report timely and relevant earnings to minority investors in family firms. Additionally, the 
study also finds that markets perceive family-controlled firms as more likely to have increased agency costs when using long-term debt.

To date, there are only a few studies that examine the association between family firms and the quality of financial reporting in Malaysia. Studies by Haniffa and Cooke (2002) and Ghazali and Weetman (2006) find that family firms disclose less voluntary information and are less transparent than nonfamily firms. Specifically, Haniffa and Cooke (2002) find a significant negative association between the proportion of family members on the board and the extent of voluntary disclosures by Malaysian companies. Haniffa and Cooke (2002) justify the negative association between the proportion of family members and the extent of voluntary disclosure in their study as being due to the fact that there is less demand for published information in family firms as the majority of the owners have easy access to internal information.

Haniffa and Cooke's (2002) study was extended by Ghazali and Weetman (2006) to include the period after the 1997 financial crisis. Ghazali and Weetman (2006) suggest that family owned companies tend to preserve tradition inherited from the past and have resisted changing their attitude towards greater voluntary disclosure, even after the corporate governance reforms. A study by Wan-Hussin (2009) takes a contrary view and reports that companies with a higher proportion of family members on the board are more inclined to disclose all the required items for the primary basis of segment reporting. The study concludes that the alignment effect of family firms leads to high corporate transparency. 
The alignment effect of family firms is also evidenced in the Saw-Imm, Ali and Pillay (2006) study that examines the relationship between ownership identity of the largest shareholders, premiums paid and take-over performance in Malaysia. With reference to 63 large acquisitions by Malaysian public listed firms from 1990 to 1999 , they find that the premiums paid are much higher than those in developed countries and have a curvilinear relationship with take-over performance. Lower to moderate levels of premiums improve firms' post-take-over performance, while excessive premiums drag down the performance of the bidding firms. Their findings also show that there is an interaction effect between family ownership and premiums paid which contributes positively to the post-take-over performance, suggesting that family ownership mitigates agency problems in corporate take-overs.

A related study of family firms in Malaysia, by Chu and Cheah (2006) finds that family controlled firms are less efficient, in terms of lower ROA as compared to foreign owned firms. However, even though family controlled firms show up poorly in terms of ROA, their performance is significantly better in terms of the PE ratio. Family firms suffered less from the adverse impacts of the 1997 economic crisis compared to other structures, including conglomerate and state controlled firms. Relative to other structures, family controlled firms are also found to have significantly stronger sales expansion after the financial crisis period. The study concludes that, in principle, family controlled firms still maintain the passion of entrepreneurship, which focuses on firm's expansion, as well as maximisation of shareholder value. 
A review of literature on earnings management in family firms by Bhaumik and Gregoriou (2010) finds that while the literature on the various aspects of family control is rich, empirical studies are relatively few. They suggest that future studies should undertake empirical examination of issues relating to family firms, especially those concerning the impact of agency conflicts and institutional implications. As little is known about the effect of family influence on the quality of earnings especially in a weak institutional environment like Malaysia, further investigation is warranted.

\subsection{Prior Studies of Corporate Governance}

\subsubsection{Definition of Corporate Governance}

The importance of corporate governance to ensuring effective monitoring has been widely discussed in the prior literature. However, the literature provides no common definition of what corporate governance is. Shleifer and Vishny (1997) explain that corporate governance is a set of instruments that should be in place to guarantee the maximum rate of return on investments of the shareholders and creditors of a company. Similarly, John and Senbet (1998) state that corporate governance encompasses the set of mechanisms that protect shareholders interests and by which shareholders of a corporation exercise control over corporate insiders and management. According to Labelle, Gargouri and Francoeur (2010) corporate governance is the set of principles or rules aimed at improving the accuracy and reliability of financial statements to ensure protection of investors. Also based on the 
agency perspective, a narrower definition is provided by Mitton (2002), who define corporate governance as the means by which minority shareholders are protected from expropriation by managers or controlling shareholders. Corporate governance acts as a set of controls that govern the behavior of managers, define their discretionary powers, and serve to offset potential losses due to the conflict of interest between shareholders and managers (Bozec and Bozec, 2007).

Another group of studies define corporate governance in terms of the connection between the stakeholders. Monks (1994) states that corporate governance is the relationship between the various participants who determine the direction and performance of corporations. According to Tricker (1994), corporate governance helps address the issue facing the boards of directors, including the interaction with top management, and relationship with the owners and others interested in the affairs of the company, such as creditors, debt financiers, analysts, auditors and corporate regulators.

Corporate governance is also defined as a monitoring process or system. For instance, Demb and Neubauer (1992) define corporate governance as the process by which corporations are made responsive to the rights of stakeholders. Cheung and Chan (2004) define corporate governance as the system through which the behavior of a company is monitored and controlled. They explain that corporate governance is significant especially in the large corporations of modern economies, which are typically characterised by separation between the parties who provide the capital and 
the parties who manage the resources. Corporate governance could minimise the conflict of interest among the two sets of parties and ensure that the company management is properly monitored (Cheung and Chan, 2004).

The Cadbury Report (1992, para 2.5) states that "corporate governance is the system by which companies are directed and controlled". The report explains that the board of directors and auditors are appointed by the shareholders to ensure that appropriate governance is in place. The board is thus responsible to supervise the management of the business and report to shareholders on their stewardship (Cadbury, 1992). Similarly, the OECD (2004) describes corporate governance as a set of relationships between a company's board of directors and stakeholders. The OECD Principles of Corporate Governance (2004, p. 11) states that:

Corporate governance involves a set of relationships between a company's management, its board, its shareholders and other stakeholders. Corporate governance also provides the structure through which the objectives of the company are set, and the means of attaining those objectives and monitoring performance are determined. Good corporate governance should provide proper incentives for the board and management to pursue objectives that are in the interests of the company and its shareholders and should facilitate effective monitoring.

In Malaysia, the Finance Committee on Corporate Governance (2000, p. 52) defines corporate governance as:

...the process and structure used to direct and manage the business and affairs of the company towards enhancing business prosperity and corporate accountability with the ultimate objective of realising long term shareholder value, whilst taking into account the interests of other stakeholders. 
Although the definition of corporate governance in the literature varies, it is basically concerned with both the internal controls and board structure, and external aspects including the relationship with shareholders and stakeholders (Rahman, 2006).

\subsubsection{Corporate Governance and Earnings Quality}

There are numerous studies on earnings quality and corporate governance in the academic journals (e.g. Chang and Sun, 2009; García Lara, García Osma, and Penalva, 2007; Machuga and Teitel, 2007, 2009). These studies have, at least in part, been motivated by the economic crises and unexpected business failures that occurred world-wide (Chia, Lapsley, and Lee, 2007; Cohen, Krishnamoorthy, and Wright, 2004; Habib and Azim, 2008; Hermanns, 2006; Rahman, 2006). Such studies become more relevant as business communities become more concerned about the importance of having sufficiently robust corporate governance to ensure high quality of corporate financial reports. A summary of studies on corporate governance and earnings quality is provided in Appendix 4.

Extant studies document that low quality of earnings is systematically related to weaknesses in the oversight of management. Specifically, the studies show that firms that report high quality earnings are more likely to have higher quality external auditors (Chia et al., 2007; Teitel and Machuga, 2010), more likely to have an audit committee (Baxter and Cotter, 2009; Dechow, Sloan, and Sweeney, 1996), more likely to have a larger audit committee (Lin, Li, and Yang, 2006; Yang and Krishnan, 2005), more likely to have a more independent audit committee (Abbott, Parker, and 
Peters, 2004; Bradbury, Mak, and Tan, 2006; Chang and Sun, 2009; Davidson, Goodwin-Stewart, and Kent, 2005; Klein, 2002; Xie et al., 2003), more likely to have greater audit committee financial expertise (Bédard et al., 2004; Archambeault and DeZoort, 2001; Raghunandan et al., 2001; Raghunandan and Read, 2001; Krishnan, 2005), more likely to have smaller board (Eisenberg, Sundgren, and Wells, 1998; Mak and Kusnadi, 2005; Vafeas, 2000; Yermack, 1996), less likely to have a CEO who also serves as chairman of the board (Chang and Sun, 2009; Chau and Gray, 2010), more likely to have higher proportion of outside independent directors (Chau and Gray, 2010; Jaggi and Tsui, 2007; Petra, 2007) and more likely to have higher proportion of non-executive directors (Davidson et al., 2005; Peasnell, Pope, and Young, 2005; Xie et al., 2003).

Bédard, Chroutou and Courteau (2004) study the effect of a firm's corporate governance practices on earnings quality, in terms of the extent of earnings management. Specifically, the empirical study examines whether the expertise, independence and activities of a firm's audit committee is associated with the quality of its publicly released financial information. The study concluded that the quality of earnings is positively associated with audit committee members' financial and governance expertise, the independence of the audit committee members, and the presence of a clear mandate defining the responsibilities of the committee.

García Lara et al. (2007) investigate the relationship between board of directors characteristics and conditional accounting conservatism. According to García Lara et al. (2007) strong corporate governance promotes efficient monitoring by the board of 
directors, that results in higher financial statement transparency; lower accounting manipulation, particularly in terms of lower income-increasing earnings management; constraints on the ability of managers to conceal bad news for a long period of time; and greater independence of committees such as the audit and remuneration committees to monitor management. Their evidence shows that for firms where the CEO has a low level of influence over the functioning of the board of directors have a greater degree of accounting conservatism. They conclude that even in an institutional setting with low litigation risk such as Spain, firms with strong boards use conservative accounting numbers as a governance tool to protect shareholders interests.

Another study by Machuga and Teitel (2009) focuses on the association between earnings quality and three board characteristics, which are the board composition disclosure, family concentrated ownership and 'shared-directors', who have more than one directorship. The study finds that firms that do not have concentrated family ownership or shared-directors have higher earnings quality than firms that have concentrated family ownership or shared-directors. Based on their findings, Machuga and Teitel (2009) highlight the importance of considering cultural and legal environments when assessing the impact of board-level corporate governance reforms on earnings quality, as the environment may limit the expected result.

Given that the institutional setting could have some impact on the earnings quality corporate governance relationship, another strand of studies includes institutional 
variables such as the introduction of a code of corporate governance or new regulations. For example, Machuga and Teitel (2007) investigate whether the introduction of the code of corporate governance improves the earnings quality of firms in Mexico. Using three earnings quality characteristics, viz, income smoothing, timeliness of earnings, and abnormal accruals, Machuga and Teitel (2007) find that firms that are listed exclusively on the Mexican stock exchange show all three forms of improvement in earnings quality after the implementation of the code. However, Mexican firms listed on the U.S. stock exchange only show improvements in terms of lower income smoothing and more timely loss recognition. The study concludes that different reporting requirements and incentives faced by the firms influence the effect of the Mexican Code of Corporate Governance on firms' earnings quality. Firms that are cross-listed on the U.S. stock exchange prepare their financial statements under better reporting standards and are under higher regulatory and investor scrutiny than do firms that do not cross-list in the U.S. The improvement in corporate governance does not have as much impact on the cross-listed firms as they already have higher earnings quality compared to other firms during the pre-code period.

Based on a similar notion of the role of the institutional environment, Chang and Sun (2009) examine whether the provisions of SOX improve the effectiveness of corporate-governance in monitoring the earnings quality of cross-listed foreign firms. They hypothesise that SOX improves the effectiveness of corporate governance monitoring functions due to greater oversight on financial reporting practices. In addition, the passage of SOX creates great pressure on cross-listed foreign firms to 
reshape their corporate-governance structures in order to maintain their listing status in the U.S. markets. Chang and Sun (2009) find that earnings informativeness (earnings management) is positively (negatively) associated with the aggregate corporate-governance score in both the pre- and post-SOX periods. Therefore, Chang and Sun (2009) conclude that the SOX provisions and subsequent regulations have changed the market's perceptions of the role of corporate governance in monitoring the quality of accounting earnings. Furthermore, the effectiveness of firms' corporate governance in monitoring earnings management behavior improved after the implementation of SOX.

In Malaysia, there are a number of studies that examine the association between corporate governance and the quality of earnings. However, the evidence is mixed. Saleh et al. (2005), who examined the effectiveness of some board characteristics for monitoring management behavior with respect to their incentives to manage earnings, find that earnings management is negatively related to management ownership, but positively related to the existence of CEO-Chairman duality. Their result also shows that directors that have multiple directorships are more likely to detect earnings management practices to avoid losses. The study also reports that the ratio of independent board members is not significantly related to earnings management in firms with CEO-Chairman duality.

Rahman and Ali (2006) examine whether size and independence of the board of directors, audit committee and concentrated ownership are effective in reducing 
earnings management among 97 firms listed on the Main Board of Bursa Malaysia over the period 2002-2003. The study finds that earnings management is positively related to the size of the board of directors, supporting the view that larger boards are less effective in their oversight duties relative to smaller boards. However, the study did not find any significant association between the independence of board or audit committee or concentrated ownership, and earnings management.

Abdullah and Nasir (2004) investigate whether firm's internal corporate governance, namely the independence of the board of directors and the audit committee have the ability to constrain the management of discretionary accruals. Using data from the Kuala Lumpur Stock Exchange (KLSE) non-financial Main Board listed companies in 1998, they find that neither board independence nor the audit committee independence effectively are significantly associated with firm's accrual management.

Another study by Saleh, Iskandar and Rahmat (2007) examines the effectiveness of some audit committee characteristics, that is, the independence of members, size of the committee, frequency of meeting, and knowledge of the members, to monitor management behavior with respect to their incentives to manage earnings. Saleh et al. (2007) find that the presence of a fully independent audit committee, more knowledgeable audit committee members and more frequent audit committee meetings reduces earnings management practices. 
Using data from Malaysia and Singapore, Bradbury, Mak and Tan (2006) report similar evidence relating to the association between audit committees independence and financial reporting quality. Specifically, the study finds that audit committee independence is related to higher quality accounting when the abnormal accruals are positive and when all members are independent directors. The study concludes that audit committees are effective in the financial reporting process by reducing the level of positive abnormal accruals.

\subsubsection{The Mediating Effect of Family Firms on the Corporate Governance-Earnings} Quality Relationship

Although the literature surrounding family firms, corporate governance and earnings quality is rich, empirical studies that examine the effect of family ownership or control on the relationship between corporate governance and earnings quality are still sparse. Among the few studies is an empirical examination by Jaggi and Leung (2007) on the impact of family dominance on monitoring of earnings management by audit committees. Using 523 observations of Hong Kong firms during the period 1999-2000, the study examines whether the establishment of audit committees by Hong Kong firms would constrain earnings management, especially in firms with concentrated ownership and family-dominated corporate boards. The study shows that the existence of an audit committee is negatively associated with earnings management. The effectiveness of the audit committees is, however, significantly reduced when family members are present on corporate boards, especially when family members dominate the corporate board. Based on the results, Jaggi and Leung 
(2007) conclude that audit committees can provide effective monitoring of earnings management even for firms that operate in the institutional environment where family ownership and control is high, the protection for investor rights is low and managers' motivation to manage earnings is high. Nevertheless, the appointment of family members on corporate boards reduces corporate board independence and thus the monitoring effectiveness of audit committees.

Similar results are documented in Jaggi et al. (2009), who investigate whether there is an association between corporate board independence and earnings management in Hong Kong firms, and whether family control influences the association between board independence and earnings quality. Their findings shows that the independent corporate boards of Hong Kong firms provide effective monitoring of earnings management, suggesting that corporate board independence is important to ensure high-quality financial reporting in Hong Kong, in which the institutional environment differ from that of the US and UK firms. However, their findings also show that the monitoring effectiveness of corporate boards is moderated in family firms, through ownership concentration and the presence of family members on corporate boards. Thus, Jaggi et al. (2009) conclude that an increase in the proportion of outside directors to strengthen board monitoring is unlikely to be effective in familycontrolled firms.

A recent study by Prencipe and Bar-Yosef (2011) examines the effectiveness of board independence on earnings management in family-controlled companies. The 
empirical analysis is based on a sample of Italian listed companies, which includes a relatively large proportion of family-controlled companies. The authors hypothesise that, due to the lower board member independence in family-controlled companies, the impact of the board on earnings management is weaker. This is because even if the board members are formally independent, they may have implicit ties to the controlling-family. Therefore, the board members may not effectively be independent. Also, when the CEO and the board chairman appointments are significantly influenced by the controlling-family, the extent of formal separation of between the CEO and the chairman may not be as clear as in non-family-controlled companies. Based on this argument, Prencipe and Bar-Yosef (2011) estimate board independence using two parameters (i) proportion of independent directors on board, and (ii) lack of CEO/Board Chairman duality, with special attention paid to the case where the CEO is a member of the controlling-family. Their empirical results provide evidence that the impact of board independence on earnings management is weaker in family-controlled companies. The same result is found for lack of CEO/Board Chairman duality, when the CEO is a member of the controlling-family.

A related study by Choi et al. (2007) reports a significant difference in the effect of governance mechanisms, the outside independent directors, on firm value between Chaebol vs. non-Chaebol firms in Korea. In general, they find that the results of the Chaebol sample are much weaker overall compared to the non-Chaebol sample. They suggests that Chaebols are so powerful in Korea that they could possibly dominate 
and nullify the oversight and market discipline function of internal and external governance mechanisms.

\subsection{Summary of the Chapter}

This chapter reviews prior studies that provide an understanding of earnings quality concepts, the special features of family firms, and corporate governance. It presents various definitions of earnings quality and discussed proxies used in empirical literature to measure earnings quality. Prior studies measure earnings quality by using time-series properties of earnings including earnings persistence, predictability, timeliness and volatility; relating accruals to future cash flows, associating earnings with stock market metrics such as stock prices and returns and assessing the level of discretionary accruals. The literature emphasises that the quality of earnings is very important as the earnings figure is widely used in many contractual agreements and investing decisions.

Even though many agree that family firms are the most common form of business corporation around the world (Burkart et al., 2003), existing research on family firms is still limited. Extant studies on family firms are mainly supported by two agency theories, which are based on (1) the relationship between shareholders and managers, and (2) the relationship between the controlling family and minority shareholders. Studies on family firms are interesting due to the special issues related to family firms including altruism, long-term horizon, lower monitoring cost, divergence of interest between family and minority shareholders, hiring of family managers and 
expropriation of minority interests. As prior studies provide evidence of the relationship between earnings quality and family firms is mainly based on developed countries, the current study focuses on earnings quality of family firms in an emerging country, where expropriation of minority interests could be more prevalent.

A review of prior studies on the relationship between corporate governance and earnings quality shows that the findings of prior studies are inconclusive. This could be due to factors such as differences in institutional environment and other influences that could affect the effectiveness of corporate governance mechanisms of companies in their sample. For instance, the discussion relating to corporate governance in family firms suggests a possibility that family influence through share ownership and control over the board of directors could affect the effectiveness of firms' corporate governance. While family influence could affect the effectiveness of corporate governance mechanisms in monitoring the quality of financial reports, its effect on the relationship between corporate governance and earnings quality has not been extensively explored. 


\section{CHAPTER FOUR: THEORETICAL FRAMEWORK, DEVELOPMENT OF THE HYPOTHESES AND RESEARCH METHODOLOGY}

\subsection{Introduction}

The previous chapter provided an overview of empirical studies on earnings quality, family firms and corporate governance. This chapter explains the theoretical framework; develops hypotheses predicting the relationships between earnings quality, family influence and corporate governance; and provides the research methodology of the study including the sample selection, measurement of variables, regression models and robustness analysis.

This chapter has eleven main sections. Section 4.2 describes the theoretical framework of this study that relates earnings quality to family influence and corporate governance. Section 4.3 provides the argument underlying the development of each specific hypothesis. It is divided into three subsections based on the research objectives. The sample selection and data is described in Section 4.4. Section 4.5 discusses measurement of the dependent variable in this study, which is the earnings quality. The process of identifying the family and nonfamily firms used in the study is outlined in Section 4.6. Section 4.7 presents the measures for the seven corporate governance variables. The specification of the control variables included in the analysis is set out in Section 4.8. Section 4.9 sets out the regression models to tests the hypotheses. The sensitivity and robustness tests performed to ensure that the 
results generated by the regressions are robust are set out in Section 4.10. Finally, Section 4.11 summarises this chapter.

\subsection{Theoretical Framework of the Empirical Study}

The three objectives of this study are to examine (1) the association between family firms and earnings quality, (2) the association between corporate governance and earnings quality, and (3) the influence of family firms on the relationship between corporate governance and earnings quality. To achieve these objectives, this study uses the theoretical framework presented in Figure 4.1. The diagram shows all the variables investigated in the study.

Firstly, the current study examines the association between family ownership and control and earnings quality. The relationship between family ownership and control and earnings quality can be explained by agency theory, which focuses on the separation of ownership and control in a firm. It is based on the idea that managers who are not owners will not watch over the affairs of a firm as diligently as the owners (Chrisman, Chua, and Litz, 2004). The conflict of interests that results from the separation between owners and managers is called "principal-agent" problem by Ross (1973). According to Ross (1973), the principal-agent problem arises when the owners (principal) grant authority to the managers (agents) to act on their behalf. Basically, it is due to the divergence of interests and information asymmetry between the managers and owners (Jensen and Meckling, 1976). According to Jensen and Meckling (1976), agency problems could be eliminated if both parties have the same 
interests. However, if agents and principals are different parties they might not have their interests aligned. The agents might have the incentive to maximise their own wealth at the expense of the principals. Moreover, the agents have the advantage of having more or better information than the principal does, the decision situation, or the consequences of actions (Ross, 1973).

Similarly, Fama and Jensen (1983b) suggest that agency problems that arise from the separation of ownership and control could be reduced if the residual claimants (shareholders) and the decision agents (managers) in a firm are the same. This is because, the interests of shareholders and managers are closely aligned. Thus, in firms where the ownership and control rest with the same group of people or individual, the need for monitoring by outside shareholders is reduced (McConaughy et al., 1998). This argument is relevant for family-owned firms because the majority of family firms are managed by the controlling family (Claessens et al., 2000).

The agency problems between managers and shareholders could be lower in family firms. This is because in family firms, the family usually owns a significant portion of the firm's equity and often maintains control over the management. According to Habib (2005), in a firm with diffuse ownership structure and low level of a managerial shareholding, the managers might try to present the operating result of the firm in the most favourable manner possible in order to avoid shareholder unrest, or to lessen the probability of takeover attempts. In contrast, in a firm with more concentrated ownership, such as in family-owned firms, the managers do not need 
earnings manipulation as a job-preserving strategy, because the owners possess control of the firm. Thus, less earnings manipulation, or higher earnings quality could be expected in family-owned firms, relative to firms with diffuse ownership structure. According to Chen, et al. (2008), concentrated ownership also reduces the attention toward stock market fluctuations in the short term and lowers market pressures caused by meeting or beating analyst forecasts. As the managers' incentives to report accounting information that deviates from the underlying economic performance is reduced, financial reporting quality of firms with concentrated ownership should therefore increase (Warfield, Wild, and Wild, 1995).

However, it is also argued that agency conflicts in family firms do not lie between the owners and managers, but between the controlling family and minority shareholders. Morck, Shleifer, and Vishny (1988) documented that when a firm has an entrenched dominant shareholder, there is the potential that agency conflicts with minority shareholders would arise. Family influence exists when family members owns a significant portion of the firm's equity and/or family members hold positions as directors on the firm's board. With the power to control the board and influence managerial decisions, the family has the potential to make decisions that are not in the best interests of the minority shareholders. This is labelled a Type II agency problem. In this case, the existence of family could lead to lower earnings quality.

Secondly, the current study examines the relationship between earnings quality and various corporate governance variables, including size of the audit committee, audit 
committee independence, audit committee meeting frequency, audit committee financial expertise, board independence, board size, and separation between CEO and chairman roles (duality). Corporate governance mechanisms evolve to resolve the agency conflicts between the owners and managers in a company (Beasley, 1996; Fama and Jensen, 1983b). Shleifer and Vishny (1986) note that strong corporate governance within a firm would mitigate the problem of information asymmetry and reduce agency costs through the alignment of interests between the managers and shareholders. Thus, higher earnings quality could be expected in firms with stronger corporate governance.

Thirdly, the study examines the mitigating effect of the influence of family firms on the relationship between corporate governance and earnings quality. Based on the argument presented in Section 4.3.3 below, it is expected that the presence of family influence would weaken the impact of corporate governance on earnings quality. The expected links between the three variables; family firms, corporate governance and earnings quality, as modelled in Figure 4.1 is the framework used to develop the hypotheses of this study.

Control variables such as the quality of external auditors, firm growth, leverage, size, occurrence of loss, sales variability, capital intensity, operating cycle, variability of cash flows, intangible intensity and financial distress are also included in the analysis. These variables are included based on previous studies that show their impact on earnings quality. 


\section{Figure 4.1: Framework of the Study}

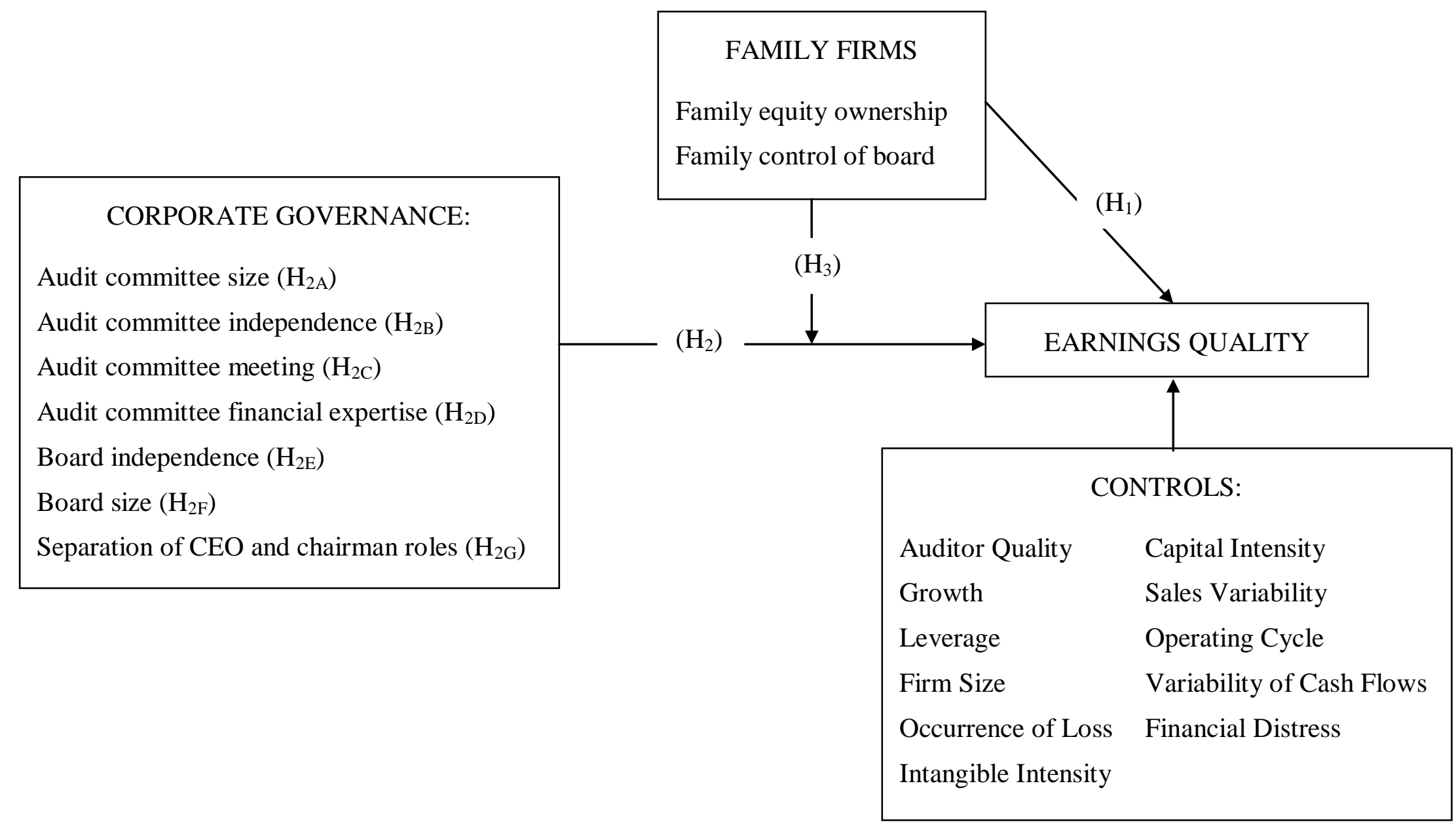




\subsection{Development of the Hypotheses}

This section presents related hypotheses developed to answer the question of whether earnings quality is associated with family firms and corporate governance, and whether family influence mitigates the relationship between earnings quality and corporate governance. In Section 4.3.1, the development of the hypothesis related to earnings quality and family firms is explained. The arguments and rationale for hypotheses relating to earnings quality and corporate governance are provided in section 4.3.2. In Section 4.3.3, the explanation for hypothesis relating to the mediating effect of family firms on the earnings quality-corporate governance relationship is presented.

\subsubsection{Earnings Quality and Family Firms}

Fama and Jensen (1983b) suggest that firms owned by a family should be more efficient than firms with dispersed ownership due to lower monitoring costs. In firms with dispersed ownership, agency problems arise due to information asymmetries and different incentives for managers and owners (Miller and Le Breton-Miller, 2006). With superior knowledge about the business and capacity as agents for the owners, managers have the ability to exploit or expropriate business resources that otherwise would provide returns to the owners. They could report accounting information that deviates from the substance of underlying economic transactions for the purpose of maximising their private benefits (Leuz et al., 2003; Warfield et al., 1995). This is supported by Jensen and Meckling (1976), who indicate that managers with lower firm ownership have greater incentives to manipulate accounting numbers. 
Unlike diffusely owned firms, in which ownership and control are separated, family members in family firms usually hold a significant portion of the shares and often control top management positions (Anderson and Reeb, 2003a). Therefore, in family firms, the agency problems caused by the separation between owner and manager ${ }^{15}$, could be low relative to diffusely owned firms because the owners' and managers' interest are very much aligned (Anderson and Reeb, 2003a).

The concentrated ownership of family firms might also contribute towards the better monitoring of managerial activities (Anderson and Reeb, 2003a; Demsetz and Lehn, 1985). The efficient monitoring in family firms leads to lower earnings management and higher quality accounting information on earnings. Wang (2006) and Bushman et al. (2004) argue that because of the better monitoring of managers by family owners, the demand for information from non-family owners to monitor managers is lower due to the substitutive relation between direct monitoring and public disclosure.

The family members/shareholders usually hold their investments for a long-term period, and pass the investments to multiple generations. Families often hold an undiversified portfolio of shares, and thus, are very concerned about the long- term survival of the firm. Due to the long-term investment horizon and reputation concerns, Sanchez et al. (2007) explain that family members/ shareholders would tend to maximise firm's wealth in the long-run rather than consume it during their lifetime. Similarly, DeAngelo and DeAngelo (1985) suggest that family involvement

\footnotetext{
${ }^{15}$ Agency problems caused by the separation between owners and managers are usually referred to as Type I agency problems.
} 
serves to monitor and discipline managers because of the long-term relationships that exist between family members and the firm. According to Anderson et al. (2003), the controlling family represents a special class of shareholder that potentially has a unique incentive structure, a strong voice in the firm and powerful motives to effectively manage the firm. Anderson et al. (2003) study finds that bondholders charge a lower cost of debt for family firms, as it is regarded as an organisational structure that protects their interests.

Family firms are also characterised by having special attributes that can promote an atmosphere of love and commitment (James, 1999). Schulze et al. (2003) highlights that family altruism encourages family members to be considerate to each other and fosters loyalty and commitment to the family and firm. Similarly, from the economist's point of view, altruism is modeled as a utility function in which the welfare of one family member is positively related to the welfare of the others in the firm (Bergstrom, 1989). Family loyalty, concern over business reputation and wealth, the desire to pass the business to heirs as a going concern, would all contribute to better monitoring of business conduct, including the reporting of high quality of earnings.

However, family firms may suffer more severe Type II agency problems, which are caused by the incentive and ability of controlling shareholders to extract private benefits at the expense of minority shareholders (Fama and Jensen, 1983b; Morck et al., 1988; Shleifer and Vishny, 1997). This is called the entrenchment effect of 
controlling shareholders. According to Warfield et al. (1995), in extracting private benefits from minority shareholders, the controlling shareholders have the desire to prevent the detection of their behaviour, which creates incentives to alter reported earnings. This causes the controlling family to report accounting information that is based on family self-interest rather than a reflection of the firm's underlying economic transactions (Sánchez et al., 2007). In addition to that, the informal relationships of family owners and managers in family firms may harm the credibility of or access to earnings information (Salvato and Moores, 2010).

Evidence of the family entrenchment effect is found in Machuga and Teitel (2009), Choi et al. (2007). Machuga and Teitel (2009) investigate earnings quality surrounding the implementation of the code of corporate governance in Mexico. Their results show that firms, which do not have concentrated family ownership, have greater increases in earnings quality in terms of lesser income smoothing, more timely loss recognition and lower conditional accrual. Similarly, using sample from Korea, Choi et al. (2007) find that firms with chaebol or family control in the board of directors report significantly lower performance.

According to studies on corporate ownership around the world (e.g. Claessens et al., 2000; Faccio and Lang, 2002; La Porta et al., 1999), the risk of expropriation by the dominant or controlling shareholders at the expense of minority shareholders are the main agency problem in countries other than the US and the UK. Peng and Jiang (2006) explain that developed countries have better legal and regulatory institutions 
that enable the benefits of family ownership to outweigh the drawbacks of controlling shareholders because the government is better equipped to control manipulation of earnings. On the other hand, less developed countries and emerging markets provide greater opportunities for families to manage earnings due to weak investor protection and the lack of a market for corporate control (Bhaumik and Gregoriou, 2010). Because of this, the effect of Type II agency problems in family firms could be more prevalent in these countries. Since the arguments on the alignment and entrenchment effects of family firms provides contradicting predictions about the effect of family ownership on earnings quality, the first hypothesis is stated in null form, as follows:

$\mathrm{H}_{1}$ : There is no difference between earnings quality in family and nonfamily firms.

\subsubsection{Earnings Quality and Corporate Governance}

According to the Malaysian Code on Corporate Governance, corporate governance is the process and structure used to direct and manage the business and affairs of a company to enhance business prosperity and corporate accountability (Finance Committee on Corporate Governance, 2000). It is comprised of the mechanisms used by stakeholders of a corporation to exercise control over corporate insiders and management (John and Senbet, 1998). Dechow, Sloan and Sweeney (1996) highlight that the establishment of governance processes is essential to maintain the credibility of firms' financial statements and safeguard against earnings manipulation. Strong corporate governance is expected to be able to protect stakeholders interests, curb agency conflicts and limit agency costs (Haniffa and Hudaib, 2006). 
Agency theory predicts that good corporate governance can strengthen monitoring and control of managers (Fama and Jensen, 1983b). According to Ho and Wong (2001), the adoption of good governance mechanisms provides an "intensive monitoring package" for a firm to reduce opportunistic behaviours and information asymmetry (Leftwich, Watts, and Zimmerman, 1981; Welker, 1995). Under such an environment, it is difficult for managers to withhold any information or disclose false information for their own benefit (Ho and Wong, 2001). Therefore, having good corporate governance promotes transparency and accountability in the firm's information; which subsequently has a positive impact on the level of earnings quality (Johnson et al., 2002). The development of hypotheses related to corporate governance mechanisms examined in this study is as follows:

\subsubsection{Earnings Quality and Audit Committee Size}

Audit committees are independent committees charged with overseeing a company's financial reporting process. In Malaysia, audit committees are responsible for reviewing earnings releases and financial reports; assessing the appropriateness of management's selection of accounting policies and disclosures in compliance with approved accounting standards; ensuring timely submission of financial statements by management; reviewing significant or unusual transactions and accounting estimates, reviewing and understanding management's representation; assessing whether the financial report presents a true and fair view of the company's financial position and performance and complies with regulatory requirements (Bursa 
Malaysia, 2009). According to Xie et al. (2003), an audit committee that is wellstructured, active and well-functioning can prevent manipulation of accounting numbers.

A larger audit committee is argued to provide better governance in ensuring the reliability of financial statements. According to Mangena and Tauringana (2008), the size of the audit committee could influence the engagement of audit committee members to review interim reports. The complexity of the accounting and financial reporting matters reviewed by the audit committee requires considerable director resources, including the number of directors and time devoted to the work of the committee (Mangena and Tauringana, 2008). A larger audit committee has more resources to oversee the financial reporting and internal control systems (Anderson, Mansi, and Reeb, 2004), and thus would be more effective in uncovering and resolving potential problems in the financial reporting process.

Evidence on the association between audit committee size and earnings quality has been presented in a number of studies including Yang and Krishnan (2005) and Lin et al. (2006). Using a sample of 896 firm-year observation for the years 1996-2000 in the US, Yang and Krishnan (2005) find that larger audit committees are associated with lower quarterly earnings management. Specifically, they show that the number of directors in an audit committee is significantly negatively associated with total discretionary accruals and current discretionary accruals. Lin et al. (2006) provide similar evidence when they examine the association between audit committee 
characteristics and the restatement of reported earnings. They note that the negative association between audit committee size and the occurrence of earnings restatement suggests that a larger audit committee may provide more oversight over the financial reporting process, which consequently improves earnings quality and reduces the probability of restating financial statements. In Malaysia, Ahmad-Zaluki and WanHussin (2010) find that a larger audit committee is associated with higher quality of financial information disclosure, measured by the accuracy of the IPO management earnings forecast. Based on the evidence that audit committee size is significant in mitigating earnings manipulation and improving the quality of reported earnings, this study hypothesises that:

$\mathrm{H}_{2 \mathrm{~A}}$ : There is a positive relationship between earnings quality and the size of the audit committee

\subsubsection{Earnings Quality and Audit Committee Independence}

Audit committee independence is one of the attributes of an effective corporate governance system. A more independent audit committee would be able to provide more objective monitoring of the company's internal control and financial reporting. According to Abbott et al. (2004), a more independent audit committee is related to better monitoring for at least two reasons. First, independent directors do not have personal or economic interests in the company that may interfere with their ability to question management (Carcello and Neal, 2000, 2003). Thus, they are able to put their arguments forward without fear and favour (Beasley, Carcello, Hermanson, and 
Lapides, 2000). Second, each independent director in the audit committee has unique motivation to provide better monitoring in order to preserve and develop their reputation (Abbott et al., 2004). According to Beasley (1996), independent directors use their directorship to signal to the external market that they are decision experts who understand the importance of decision control and can work within such a control system. Thus, relative to non-independent directors, independent directors have greater incentive to avoid activities that would damage their reputation (Abbott and Parker, 2000; Abbott, Parker, Peters, and Rama, 2003b). Given the existence of information asymmetries and the potential for conflict of interest between managers and shareholders, an independent audit committee offers vital governance in ensuring the integrity of financial statements, in addition to that provided by external auditors.

The preference for an audit committee to be comprised of independent members has been explicitly expressed by the corporate governance committees of enquiry around the world, including the Blue Ribbon Committee (1999) and Smith Committee (2003). In the US, the Blue Ribbon Committee specifically recommends all audit committee members to be independent (Blue Ribbon Committee (BRC), 1999). In the UK, it was recommended that the audit committee should comprise of three members, all of whom should be independent non-executive directors (Smith Committee, 2003). In Malaysia, under the Bursa Malaysia Listing Requirements (2005), it is compulsory for all publicly listed companies to have a majority of independent directors and an independent chairman of the audit committee. An independent audit committee is expected to implement and support the oversight 
function of the board in several ways, which includes reviewing the company's processes for producing financial data, its internal controls, and the independence of its external auditor; and to conduct detailed discussions on those matters (Finance Committee on Corporate Governance, 2000).

Studies examining the independence of the audit committee have discovered that audit committee independence is an important factor that contributes to higher quality of financial reporting. Abbott et al. (2004) discover that companies with more independent audit committees are less likely to have financial restatements to address material omission or misstatements in respect of prior financial statements. Similarly, Beasley et al. (2000) and Persons (2005) find that audit committee independence is negatively related to the likelihood of committing financial reporting fraud. Klein (2002) shows that the presence of a majority of independent directors on the audit committee improves the quality of financial reporting, in terms of lower level of earnings management. Klein's (2002) finding, later supported by Bédard et al. (2004), is that aggressive earnings management is negatively associated with audit committee independence. Using a sample from Malaysia and Indonesia, Bradbury et al. (2006) also document that when all members are independent directors, audit committees are effective in reducing the level of income increasing abnormal accruals. According to the argument that a more independent audit committee is more effective in performing its oversight role and ensuring high quality of financial reporting, it is hypothesised that: 
$\mathrm{H}_{2 \mathrm{~B}}$ : There is positive relationship between earnings quality and audit committee independence.

\subsubsection{Earnings Quality and Audit Committee Meeting Frequency}

Existing studies provide evidence in support of the view that audit committees which meet more often are more effective in monitoring management and can potentially increase the quality of financial reporting. Specifically, the studies find that firms with audit committee that have more frequent meetings are less likely to face reporting problems (McMullen and Raghunandan, 1996), less likely to engage in fraudulent behavior (Beasley et al., 2000) and less likely to report a small earnings increase (Vafeas, 2005). Higher frequency of audit committee meetings is also related to lower occurrence of financial reporting restatements (Abbott et al., 2004), lower level of discretionary accruals (Xie et al., 2003), and less income-increasing earnings management (Bédard et al., 2004).

According to Larcker et al. (2007), the number of meetings held by the board and audit committees is evidence of monitoring activity. Meeting frequency is a signal of audit committee director liability concern and audit committee diligence (Menon and Williams, 1994). In previous studies, the frequency of audit committee meetings has been used as a proxy to measure audit committee member's effort or persistence in

performing their tasks (Dezoort, Hermanson, Archambeault, and Reed, 2002), directors monitoring activity (Collier and Gregory, 1999), and audit committee diligence (Song and Windram, 2004; Xie et al., 2003). 
Menon and Williams (1994) point out that the more often an audit committee meets, the more active it is perceived. Mangena and Tauringa (2008) mention that audit committees that are more active allow the members to perform their monitoring role more successfully. The meetings held by the audit committee provide the members with information and knowledge about relevant accounting and auditing concerns (Raghunandan, Read, and Rama, 2001), and enable them to analyse and decide appropriate actions to overcome reporting issues (Abbott, Parker, Peters, and Raghunandan, 2003a).

The argument that more frequent meeting promotes greater diligence and effectiveness of the audit committee in the monitoring firm's financial reporting leads to the following hypothesis:

$\mathrm{H}_{2 \mathrm{C}}$ : There is positive relationship between earnings quality and the frequency of audit committee meetings.

\subsubsection{Earnings Quality and Audit Committee Financial Expertise}

Previous studies support the notion that the financial expertise of the members of the audit committee is an important contribution towards high quality of financial reporting. From a survey on the efficacy of audit committees in Australian public corporations, Buckby, Dunstan and Savage (2002) conclude that the knowledge and experience of audit committee members improves audit committee effectiveness. In line with that, Krishnan and Visvanathan (2009) report that external auditors charge a 
lower fee to firms that have an audit committee with accounting financial expertise as they possess lower risk of earnings manipulation. According to Krishnan and Visvanathan (2009), accounting financial experts provide at least two enhancements to the overall effectiveness of an audit committee. First, audit committee accounting financial experts can constrain earnings manipulation by assessing the adequacy of provisions for as warranty obligations, lawsuits, and other contingencies. Second, audit committee financial experts can better understand the nature of explanations provided by management. Further, Mangena and Tauringana (2008) explain that knowledgeable audit committee members are in a better position to understand financial reporting issues and auditor judgments and therefore could provide better monitoring of the financial reporting process.

The ability of audit committee members with accounting/financial knowledge to improve a firm's internal control is evident from existing studies. After examining a sample of audit committee members who completed internal control oversight tasks, Dezoort (1998) shows that audit committee members with experience made internal control judgments more like auditors compared to members without experience. Raghunandan et al. (2001) find that audit committees with at least one member having an accounting or finance background have greater interaction with internal auditors, in terms of having longer meetings with the chief internal auditor, having private access to the chief internal auditor; and having detailed review of internal audit proposals and the results of internal auditing. Krishnan (2005) and Zhang et al. 
(2007) find that companies are more likely have internal control weaknesses, if their audit committees have less financial expertise.

Findings from empirical studies that examine audit committee characteristics and the quality of financial reporting also support the view that audit committee members' expertise is an important factor in constraining the propensity of managers to engage in earnings manipulation (e.g. Abbott et al., 2004; Agrawal and Chadha, 2005; Bédard et al., 2004; Xie et al., 2003; Yang and Krishnan, 2005). Xie et al. (2003) report that board and audit committee members with corporate or investment-banking backgrounds are associated with firms that have lower earnings management, or smaller discretionary current accruals. They claim that corporate and financial backgrounds are very important in determining the effectiveness of directors monitoring function as it contributes towards better understanding of how earnings are being managed. Similarly, Bédard et al. (2004) find that audit committee financial expertise is negatively associated with income-increasing and income-decreasing earnings management, based on the extent of abnormal accruals. They suggest that the presence of a financial expert on the audit committee reduces the likelihood of aggressive earnings management. Consistent findings are also reported by Yang and Krishnan (2005), who show that quarterly earnings management is lower for firms whose audit committee directors have greater governance expertise.

Abbott et al. (2004) examine the association between audit committee financial expertise and financial reporting restatements. They find that an audit committee that 
lacks a member with financial expertise is positively associated with the occurrence of financial reporting restatements. Consistent with Abbott et al. (2004), Agrawal and Chadha (2005) also find that firms with an audit committee that has an independent financial expert have a lower probability of having restatement of financial statements. Based on the evidence from the empirical studies, it is hypothesised that audit committee financial expertise is positively related to earnings quality:

$\mathrm{H}_{2 \mathrm{D}}$ : There is positive relationship between earnings quality and audit committee financial expertise.

\subsubsection{Earnings Quality and Board of Directors Size}

Fama and Jensen (1983b) suggest that the function of the board of directors is to minimise the agency cost that arises from the separation of ownership and control in firms. The board of directors receives authority over the internal control of the firm from shareholders. They are responsible for monitoring management to ensure that it acts in the shareholders' best interests. Although the board delegates most decision and control functions to top management, the board retains ultimate control (Beasley, 1996). Thus, the board of directors plays an important role in monitoring the quality of earnings reported to the public.

The Malaysian stock exchange (Bursa Malaysia) mentions in the Corporate Governance Guide (2009) that there is no prescriptive rule for the optimum size of the board of directors. However, the establishment of board committees would 
become impracticable with very small boards. Similarly in the Malaysian Code on Corporate Governance (2001), the Securities Commission states that the board of directors should carefully determine the optimum number of board members to ensure that there are enough members to discharge responsibilities and perform related duties. Both guidelines that are proposed by two important bodies in Malaysia, the Bursa Malaysia and the Securities Commission, indicate that the size of boards is important in determining the effectiveness of board monitoring function.

Although some studies argue that larger boards are better as they have greater capability to safeguard shareholder interest (Zahra and Pearce II, 1989), a broader range of experience (Xie et al., 2003), and varied expertise (Rahman and Ali, 2006). There are also empirical studies that show that smaller boards are more effective than large boards, due to several reasons. First, smaller boards have fewer problems in coordinating directors efforts (Eisenberg et al., 1998; Jensen, 1993; Yermack, 1996). A larger board involving a greater number of directors is more difficult to manage, as they have lower cohesion (Lipton and Lorsch, 1992). Second, unlike larger boards that have poor and slower decision-making (Goodstein, Gautam, and Boeker, 1994), smaller board have better communication and more timely decision-making (Karamanou and Vafeas, 2005). Lipton and Lorsh (1992) explain that even if a board's capacities increase with a greater number of directors, the benefits are outweighed by slower decision-making and less open discussion of managerial performance. Third, Karamanou and Vafeas (2005) highlight that smaller boards have less severe agency problems such as directors' free riding, compared to larger boards. 
The agency problems in large boards arise from dysfunctional behavior of directors on the board. This is because the cost to any individual director of not exercising diligence in monitoring management falls in proportion to the total number of board directors (Cheng, 2008). According to Jensen (1993), as the board size gets bigger, greater emphasis on politeness and courtesy at the expense of truth and frankness arises in the boardroom.

The evidence that smaller boards are associated with higher quality of earnings is provided in the following studies. Yermack (1996) shows that companies with a larger board size are associated with lower market valuations in the U.S. Similarly, Eisenberg et al. (1998) and Mak and Kusnadi (2005) find that firms with fewer directors on the board are associated with higher firm value in Finland, and Singapore and Malaysia, respectively. Vafeas (2000) discovers that the earnings of firms with the smallest board in the sample (five members in the board) is viewed as more informative by the market. The discussion above and evidence from existing studies suggests the following hypothesis:

$\mathrm{H}_{2 \mathrm{E}}$ : There is negative relationship between earnings quality and board size.

\subsubsection{Earnings Quality and Board Independence}

A number of studies have provided evidence of the association between board independence and earnings quality. For example, Petra (2007) provides evidence that there is a positive association between the proportion of outside independent directors 
serving on firm's boards and earnings informativeness. Another study, Jaggi, Leung and Gul (2009), find that a higher proportion of independent directors is associated with more effective monitoring to constrain earnings management. They conclude that the quality of earnings is higher for firms with a higher proportion of independent directors on the board. This is consistent with the earlier studies, Klein (2002) and Niu (2006) which find a negative association between earnings management and the level of board independence in the U.S. and Canada, respectively. In line with agency theory, these studies support the view that a more independent board would perform a better monitoring function, which would consequently result in a higher level of earnings quality.

As the board is viewed as a monitoring mechanism to safeguard shareholders interests, a higher proportion of independent director is preferable. This is consistent with the agency theory premise relating to the divergence of interests between shareholders and managers in a company that needs to be controlled and monitored. Independent directors are preferable as they could increase the effectiveness of the board monitoring function (Gupta and Fields, 2009; Jaggi et al., 2009), and ensure that high quality earnings are reported in the financial statements.

Among the studies that investigate this issue are Park and Shin (2004) and Gupta and Fields (2009). The latter examine a sample of Canadian firms in 1991-1997 and found that the level of earnings management does not decrease with the proportion of outside directors as board members. They conclude that in jurisdictions where 
ownership is highly concentrated and the outside directors' labor market is not well developed, the existence of outside directors would not improve corporate governance practices of firms.

Other studies, such as Xie at al. (2003) and Peasnell et al. (2005) provide evidence that the proportion of outside directors is negatively associated with earnings management. Specifically, Peasnell et al. (2005) find that the chance of abnormal accruals being large enough to turn a loss into a profit or to ensure that profit does not decline is significantly lower for firms with a high proportion of outside board members. The evidence leads to the following hypothesis:

$\mathrm{H}_{2 \mathrm{~F}}$ : There is positive relationship between earnings quality and board independence.

\subsubsection{Earnings Quality and CEO Duality}

Empirical research in corporate governance has provided strong evidence that separation between the CEO and chairman roles is preferable as it improves the effectiveness of the board monitoring function. Chau and Gray (2010) argue that a chairman who is independent has the freedom to manage a company without constraint as he possesses a great amount of power and authority. According to Jensen (1993), the presence of chairman that is also the chief executive of a company could override the advantage of having independent directors on the board and weaken the function of the board of directors. Similarly, Forker (1992) claims that the duality role of CEO and chairman could be a threat to disclosure quality. He finds 
that CEO duality is negatively associated with the quality of share option disclosure. This is because the chairman who is independent enhances the board function by monitoring the CEO and company's management, and thus has a low tendency to withhold any information from stakeholders.

Using a sample of Spanish listed firms for the period 1997-2002, García Lara et al. (2007) shows that firms with a CEO who has low influence over the functioning of the board of directors is associated with a greater degree of accounting conservatism. On the other hand, a CEO with excessive power over board matters could easily manipulate earnings numbers (Rahman and Ali, 2006). This is evidenced in Klein (2002) who finds that earnings management is positively related to the CEO holding a position on the board's nominating and compensation committee. In addition to that, there is evidence in the literature that when the position of CEO and chairman are separated, firms are valued more highly by the market (Yermack, 1996). This shows that unbiased monitoring of the CEO by the chairperson of the board signals stronger firm internal controls, which results in higher firm value.

The extant studies imply that lower earnings quality is likely to be associated with the existence of the boards' chairman also performing the CEO role. The involvement of a CEO on a board as a chairman may create bias and influence board decision making. In other words, strong influence from the company's management over the board's decisions indicates weak governance. Based on this argument, this study posits that: 
$\mathrm{H}_{2 \mathrm{G}}$ : There is negative relationship between earnings quality and CEO duality.

\subsubsection{Mediating Role of Family Influence on Corporate Governance and Earnings Quality Relationship}

As corporate control by the owner already exists in family firms, earnings quality might be good even if corporate governance was weak. This is supported by Jaggi et al. (2009) who find that family ownership control or family members on the board moderates the monitoring effectiveness of independent boards, because the founding family will limit the ability of managers to manipulate earnings. Jaggi et al. (2009) provide three explanations on why the monitoring effectiveness of independent directors moderates with the existence of family control in a firm. First, consistent with Jensen and Meckling (1976), they argue that the monitoring role of corporate governance reduces when there is a high level of insider ownership. Second, in family controlled firms, independent directors are appointed to give advice on strategy rather than to perform monitoring and controlling duties on management. Thirdly, independent directors in family firms are relatively less independent. This is due to the dominance and control of family members that exists in family firms. Since the family members have control over the appointment of outside directors, independent directors are less likely to oppose their decisions (Jaggi et al., 2009).

On the other hand, if control by the family members in family firms results in entrenchment of the controlling family and results in exploitation of minority shareholders interests, earnings quality might be weak even if the corporate 
governance is strong in form. According to Cheung and Chan (2004), in emerging economies where the majority of firms are family-owned and concentrated, corporate governance mechanisms, such as the number of independent non-executive directors, might not necessarily provide a strong system of checks and balances between the interest of the major shareholder and that of the minority shareholders. This is because the controlling families influence the formation of the corporate governance mechanisms in the firm. For example, as directors are elected by the controlling shareholders, i.e the family, it is unlikely that the independent directors will provide an adequate degree of monitoring or be able to exert a strong influence on major corporate decisions (Cheung and Chan, 2004). Cheung and Chan (2004), explain that such independent directors may serve as advisors in the decision-making process, rather than overseeing and monitoring managerial activities and the financial reporting process.

Anderson and Reeb (2003a) show that conventional corporate governance mechanisms used to mitigate agency conflicts between managers and shareholders are less effective when family opportunism is in place. Some studies reveal that corporate governance mechanisms could be strong in form, but not in substance (Cohen, Krishnamoorthy, and Wright, 2008; Gendron and Bédard, 2006). When family opportunism exists, the controlling family could make appointments of independent directors or audit committee members which would satisfy regulatory requirements, but provide less than adequate monitoring. According to Patelli and Principe (2007), the involvement of family owners in the appointment of external 
directors could impair the directors' independence and lead to potential collusion between the directors and the controlling family. This is supported by previous empirical studies, that find that independent directors appointed through the influence of family owners support the major decisions in favour of family owners rather than outside investors (Chen and Jaggi, 2000; Leung and Horwitz, 2004).

In summary, based on the alignment effect argument, which suggests that agency conflicts are relatively lower in family firms, earnings quality would be high in these firms even if the corporate governance is weak as the control by the owner already exists in these firms. On the contrary, if the entrenchment effect of the controlling family towards minority interests dominates, earnings quality would be low in family firms even if corporate governance appears to be strong in form. Either way, it is likely that in family controlled firms, the relationship between corporate governance and earnings quality would be weak. Therefore, it is hypothesised that:

H3: The relationship between earnings quality and corporate governance is weaker in family owned firms compared to nonfamily firms.

\subsection{Sample Selection and Data}

The population of this study comprises all non-financial companies listed on the Malaysian stock exchange, Bursa Malaysia, during the period 2003-2008. The data requirements to calculate the earnings quality measure significantly influenced my sample selection. Even though this study covers the six-year period of 2003-2008, 
data on the firms' cash flows from operations in the year before and after the study period is required to calculate the earnings quality measure. Thus, the study includes only companies that have a complete set of data during 2002-2009.

Table 4.1: Derivation of Sample and Industry Category

Panel A: Sample Derivation

\begin{tabular}{lr}
\hline & $\begin{array}{r}\text { Number } \\
\text { of firms }\end{array}$ \\
\cline { 2 - 2 } Companies listed on Bursa Malaysia as at 31 December 2009 & 960 \\
Companies with a fiscal year change in the period 2002-2009 & $(53)$ \\
Companies under PN17 category or suspended from trading & $(34)$ \\
Financial and insurance institutions & $(37)$ \\
Utility companies & $(2)$ \\
Government owned companies & $(40)$ \\
Companies listed on Bursa Malaysia after the year 2002 & $(1)$ \\
Missing companies in Thomson One Banker database & $(13)$ \\
Companies with missing data on Cash Flows From Operations & $(3)$ \\
Companies with missing data on Changes in Working Capital & 527 \\
Final sample & \\
\hline
\end{tabular}

Panel B: Bursa Malaysia industry category of the sample firms

\begin{tabular}{lcrr}
\hline & $\begin{array}{c}\text { Number } \\
\text { of firms }\end{array}$ & & $\begin{array}{c}\text { Percentage } \\
\text { of sample }\end{array}$ \\
Construction & 35 & & 6.64 \\
Industrial product & 186 & 35.29 \\
Consumer product & 94 & 17.84 \\
Technology & 29 & 5.50 \\
Trading/ Services & 90 & 17.08 \\
Properties & 65 & 12.33 \\
Plantation & 28 & 5.31 \\
Total & 527 & \\
\cline { 2 - 3 }
\end{tabular}

Panel A of Table 4.1 outlines the sample selection procedure. Firstly, all companies listed on the Main Market of Bursa Malaysia as at 31 December 2009 are identified. On that date, there were 960 financial and non-financial companies listed on the main market. The 53 companies that had at least one fiscal year change during the period 
2002-2009 and the 34 companies in the PN17 ${ }^{16}$ category that were suspended from trading, are excluded from the sample. Consistent with previous earnings quality studies such as Peasnell et al. (2005), Davidson et al. (2005) and Klein (2002), the 37 finance and insurance companies are also excluded from the sample due to the unique nature of their reporting practices ${ }^{17}$. In addition, 2 utility companies were also excluded from the sample for the reason that they may have different incentives and opportunities to manage earnings (Peasnell et al., 2005; Rahman and Ali, 2006). 40 government-owned companies are also excluded due to the differences in their ownership structure and governance ${ }^{18}$. As the study requires data from 2002-2009 to compute the earnings quality variables, the 250 companies that were first listed on the stock exchange after the year 2002 are also omitted. . The 17 firms that lacked all the data required to compute the variables, primarily companies that did not have cash flow from operations data, were also omitted. The final sample for this study comprised 527 companies from 7 industries, based on Bursa Malaysia industry classification.

\footnotetext{
${ }^{16}$ PN17 stands for Practice Note 17/2005 issued by Bursa Malaysia. Companies in the PN17 category are financially troubled companies that meet at least one of the following criteria: companies' shareholders' funds are less than $25 \%$ of their total paid-up capital; receivers have been appointed to take control of the companies' assets; the winding-up of some of their subsidiaries and associated companies; the auditors have expressed adverse opinions on the companies; default in loan interest and principal repayments; the companies have suspended or ceased their operations; and companies do not have any significant businesses or operations.

${ }^{17}$ Financial institutions are also subject to a regulatory framework that did not apply to other companies. Particularly, they are regulated under the Banking and Financial Institutions Act 1989. Among others, the Act limits a financial institution to make portfolio investments in non-financial companies up to a maximum of 20 percent of its shareholders funds and up to 10 percent of the issued share capital of the company in which the investment is made. The financial institutions are also prohibited from assuming any management role or taking up a board position.

${ }^{18}$ The companies are considered as government owned companies if the state or federal government has a direct or indirect control over the board of directors. In Malaysia, these companies are also known as GovernmentLinked Companies (GLCs). The GLCs are controlled through seven Government-Linked Investment Companies (GLICs), the (1) Khazanah Nasional Berhad (KNB), (2) Kumpulan Wang Simpanan Pekerja (KWSP), (3) Kumpulan Wang Amanah Pencen (KWAP), (4) Lembaga Tabung Angkatan Tentera (LTAT), (5) Lembaga Tabung Haji (LTH), (6) Menteri Kewangan Diperbadankan (MKD), and (7) Permodalan Nasional Berhad (PNB).
} 
The classification of the sample firms according to their industry is shown in Panel B of Table 4.1. As shown in the table, the sample is widely distributed across the different sectors and represents most of the sectors on the Bursa Malaysia stock exchange. The concentrations in industrial products $(35.29 \%)$, consumer products (17.84 \%), trading/services $(17.08 \%)$ and properties $(12.33 \%)$ resemble the population of companies listed on Bursa Malaysia.

For the purpose of calculating the cross-sectional measure of earnings quality, 8 years of financial data over 2002-2009 were downloaded. The total of 8 years financial data used to estimate the cross-sectional estimation of earning quality comprises 4216 firm-year observations, from 527 companies. Appendix 5 lists the ticker code used in this study to extract the financial data from the Thompson Financial One Banker database. Data relating to family ownership was hand collected from the Directors Profile and Shareholding Analysis sections in the annual reports. In total, 3162 annual reports were downloaded for the 527 companies over the year 2003-2008 from the Bursa Malaysia website. Details relating to family relationship of the board of directors were examined from the Directors Profile ${ }^{19}$ and the percentage of shares owned by the family members was identified from the Shareholdings Analysis section $^{20}$

\footnotetext{
${ }^{19}$ According to Bursa Securities Listing Requirement, App 9C (3), companies are required to disclose directors information, including directors' name, age, nationality, qualification \& position (executive/ nonexecutive/ independent), working experience and occupation, date first appointed to the board, details of any board committee to which the director belongs, any directorship of public companies, any family relationship with any director and/or major shareholder, any conflict of interest with company, list of convictions for offences within the past 10 years other than traffic offences and number of board meetings attended in the financial year.

${ }^{20}$ All publicly listed firms in Malaysia are required by Section 69D (1), Companies Act 1965 to disclose information relating to substantial shareholding in the annual report. Specifically, the act stipulates the mandatory disclosure of substantial shareholders who hold more than five percent of equity in any firm irrespective of their
} 


\subsection{Measurement of Earnings Quality}

Following previous studies (Aboody et al., 2005; Francis et al., 2004; Francis et al., 2003; Myers et al., 2003; Van der Meulen et al., 2007),this study measured the quality of earnings using the accrual quality model introduced by Dechow and Dichev (2002) with some modifications as suggested by McNichols (2002). The original Dechow and Dichev (2002) model is based on the assumption that accruals maps into cash realisations, thus any measurement errors in accruals not realised in cash flows indicate low quality of accruals. The modifications suggested by McNichols (2002) adjust for changes in firms economic environment, resulting in a better proxy for earnings quality (Jaggi et al., 2009).

According to Dechow (1994) and Dechow and Dichev (2002), the accrual-based earnings solve the potential timing and matching problems associated with the use of cash flows as a short-term performance measure. In other words, the function of accruals is to adjust the recognition of cash flows over time, so that it better reflects firm performance. However, as accrual-based earnings include measures that are subject to estimations, the earnings figure could be manipulated. This will results in lower quality of earnings.

The Dechow and Dichev (2002) model relates total current accrual (TCA), to lagged, current and future cash flows from operations. It is based on the assumption that

direct or indirect control interest. This also includes their investment through nominees' institutions and others means. 
current accruals are estimates of future year's cash flow realisation. The accruals are temporary adjustments that delay or anticipate the recognition of realised cash flows. Thus, the quality of accrual depends on the precision of these estimates. In this model, total current accrual is measured by changes in working capital, since related cash-flow realisations generally occur within one year, which is as follows:

$T C A_{i, t}=\alpha_{0}+\alpha_{1, i} C F O_{i, t-1}+\alpha_{2, i} C F O_{i, t}+\alpha_{3, i} C F O_{i, t+1}+\varepsilon_{i, t}$

where $T C A_{i, t}$ is the total current accrual ${ }^{21}$ of firm $i$ in year $t$ scaled by average assets, $C F O_{i, t}$ is the cash flow from operations of firm $i$ in year $t$ scaled by average assets and $\varepsilon_{i, t}$ is the residual of firm $i$ in year $t$.

The Dechow and Dichev (2002) model captures both intentional and unintentional accrual estimation error by management, which is the inverse measure of earnings quality (Hermanns, 2006). To distinguish the unintentional accrual estimation error from the intentional, McNichols (2002) suggests future research to incorporate some variables from the Jones (1991) model, the change in revenues ( $\triangle \mathrm{REV})$ and property, plant and equipment (PPE), as additional explanatory variables in the Dechow and Dichev (2002) model. McNichols (2002) highlights that the combination of these models provide a more powerful approach to estimation of accrual quality in the presence of management discretion. This is because the inclusion of $\triangle \mathrm{REV}$ and PPE

\footnotetext{
${ }^{21}$ Total current accrual is measured as changes in working capital. It is also equivalent to the changes in current assets minus changes in current liabilities, minus changes in cash and plus with changes in short term debt.
} 
would control for unintentional estimation errors, which are related to firm and industry characteristics. The accrual quality model proposed by McNichols is as follows:

$T C A_{i, t}=\alpha_{0}+\alpha_{1, i} C F O_{i, t-1}+\alpha_{2, i} C F O_{i, t}+\alpha_{3, i} C F O_{i, t+1}+\alpha_{4, i} \Delta R E V_{i, t}+\alpha_{5, i} P P E_{i, t}+\varepsilon_{i, t}$

where $\triangle R E V_{i, t}$ is the change in revenue of firm $i$ in year $t$ scaled by average assets, $P P E_{i, t}$ is the gross property, plant and equipment of firm $i$ in year $t$ scaled by average assets, and all other variables are as previously defined.

According to Dechow and Dichev (2002), accrual quality is an inverse function of the standard deviation of firm $i$ 's estimated residual. This measure is based on the timeseries expectation of accruals behaviour, in which a larger standard deviation of the residuals implies lower accrual quality. Based on this measure, a firm that has consistently large residuals and thus small standard deviation of residuals is considered to have relatively good accrual quality because the accrual behavior is predictable. However, time-series estimation of residuals requires firms to have sufficient time-series data points. For example, Dechow and Dichev (2002) require firms to have at least eight years of annual data to be included in the sample. Since the current study uses sample from an emerging capital market, this requirement would result in selecting only few established firms that are not representative of the population of firms in the capital market. In addition to survivorship bias, there are other problems related to time-series estimation. As noted by Saleh et al. (2005), the self-reversing property of accruals may induce specification problems, in terms of 
serially correlated residuals (Peasnell, Pope, and Young, 2000); the coefficient estimates on the change in revenue ( $\triangle \mathrm{REV})$, and the property, plant and equipment (PPE) variables in the modified model are unlikely to be stationary over time; and there may be confounding effects in the estimation period that are not related to intentional estimation error (Dechow et al., 1995; Guay, Kothari, and Watts, 1996).

To avoid the problems related to time-series estimation of accrual quality, the current study uses a cross-sectional version of Dechow and Dichev (2002). Accrual quality is measured as the absolute value of residuals from industry-specific yearly regression of the modified Dechow and Dichev (2002) model, rather than the standard deviation of residuals ${ }^{22}$. In other words, this study focuses on the magnitude rather than the volatility of measurement errors. This is based on the intuition that larger residuals from the cross-sectional estimations of the model represent lower accrual quality.

Using the model in equation (4.2), the regressions are run cross-sectionally for each industry and year based on the Bursa Malaysia industry classification, to estimate the accrual quality (AQUALITY) values for each firm from the year 2003 to 2008. The regression is performed in each industry portfolio to minimise the effect of variation of accrual behavior in different industries, as well as the different impact that the economy may have on different industries. Following Francis et al. (2005), this study requires a minimum of 20 firms in each industry group to produce good estimates of

\footnotetext{
${ }^{22}$ Consistent with Baxter and Cotter (2009) and Srinidhi and Gul (2007), I do not use the standard deviation of the residuals from my cross-sectional industry model, as this would provide a measure of earnings quality across all companies in the industry group rather than just the company of interest.
} 
residuals from the regressions. These regressions generate six yearly residuals for each firms, $\varepsilon_{i, t}$, which represents measurement errors in total current accruals (Dechow and Dichev, 2002)

For an easier interpretation of the results of this study, the absolute value of the residuals estimated from the modified Dechow and Dichev (2002) model are multiplied by negative 1 to represent earnings quality (AQUALITY), so that higher value reflects better quality of earnings.

\subsection{Family and Nonfamily Firms Identification}

Extant studies on family firms use several characteristics of firms to define family firms, depending on the interest of their study. Some of the studies, (e.g. Chau and Gray, 2010; Morck et al., 1988), refer to the degree of ownership and /or management by family members based on the percentage of common shares held by the founding family and their relatives. Studies such as Haniffa and Cooke (2002), Ghazali and Weetman (2006) measure the extent of family dominance as the proportion of family members on the board. Klai (2010) uses both proxies, the percentage of family members on the board and the percentage of their shareholdings to represent family control. These studies emphasise the extent of family control, rather than the existence of significant family control in a firm.

In addition, there are also studies that identify a firm as a family firm when family members hold shares greater than a certain level of the firm's share capital and/or when family members sits on the board of directors. For example, Chu and Cheah 
(2006) classify firms with more than $20 \%$ substantial shareholdings by individual or private companies as family firms. Prencipe et al. (2008) define family firms as firms where the dominant family owns directly or indirectly more than $50 \%$ of the equity, or the dominant family controls the firm's strategic decisions. In Cascino et al. (2010) family firms are firms in which $50 \%$ of voting rights or outstanding shares (both direct and indirect) are held by family blockholders, and at least one family member holds a managerial position. Similarly, in Jiraporn and Dadalt (2009), family-owned firms are identified on the basis of the fractional equity ownership of the founding family and/or the presence of family members. In these studies, a binary variable is used to designate family control.

Another group of studies differentiates between family control and ownership based on voting rights and cash flow rights. These studies measure the extent of family control by referring to their voting rights, whereas the extent of family ownership is based on cash-flow rights (Claessens et al., 2000). However, due to pyramid structures, cross-sectional control and the use of nominee accounts, it is very hard to capture the exact percentage of the shares owned by the controlling family or other shareholders in Malaysia. Moreover, Claessens, Djankov, Fan and Lang (1999) reported that there is no significant difference between cash flow rights and voting rights in Malaysia. Therefore, the present study does not examine the extent of family influence based on the difference between cash flow rights and voting rights of the controlling family. 
Whether a firm is controlled or owned by a family is identified from the disclosure of the directors profile and shareholders statistics in the corporate annual reports. Two criteria are used to classify a firm as a family firm. The first condition for a firm to be considered as a family firm is that the family members must own a total of more than twenty percent of the shares of the company. Similar to existing research on family firms (e.g. Claessens et al., 2000; Jaggi et al., 2009; La Porta et al., 1999; Yang, 2010), this study assumes that a family that owns more than twenty percent of a firm's shares, has significant influence over the decisions made by the company. The second condition is that the firm must have at least two family members sitting on the board during the financial year. The family relationship includes father, mother, son, daughter, husband, wife, father-in-law, mother-in-law, son-in-law, daughter-in-law, brothers, sisters, nieces and nephews. Therefore, a firm is considered as a family firm (FAMILY) only if the family members own more than 20 percent of firm's shares, and two or more members of the controlling family are directors. Following Anderson, Mansi and Reeb (2003), this study creates a dummy variable that takes the value 1 for family firms, otherwise 0 . Even though it is possible to use the percentage of shares owned by the controlling shareholder, it is more appropriate to use a dichotomous variable due to the existence of pyramidal and cross-sectional control in Malaysia. In addition to that, Anderson, Mansi and Reeb (2003) argue that some families have the ability to exert control with a minimal fraction of ownership, while others require larger stakes for the same level of control due to differences in firm size, industry, business practices, and product placement. Thus, a binary variable represents a better measure of family ownership. 
Dyer (2006) argues that research examining the effect of family influence should not treat family firms as one homogeneous group. He opposes the method of classifying firms into family and non-family groups, and claims that family firms should be identified based on the assortment of dynamics in families that own and manage them. Dyer (2006), proposes a typology which classifies each family firm as either a clan firm, a professional firm, a mom and pop firm or a self-interested firm. However, the typology is hard to apply in the present research since the information required is unavailable. Nevertheless, since the current study focuses on publicly listed firms, it is most likely that all of the companies could be classified as professional family firms. Based on Dyer's (2006) typology, a professional family firm is characterised by having formal monitoring mechanisms that help ensure that the family's assets are protected.

Studies such as Villalonga and Amit (2010) and Anderson et al. (2009) classify family firms into founding family firms, in which the company founder serves as one of firm's top management; and non-founding family firms, in which firms are controlled and/or managed by the founder's heirs. Villalonga and Amit (2010) point out that distinguishing the effect of founding and other controlling families is important because the effect of family ownership and control differs across these two group of companies. They argue that even though founding families may be more inclined to appoint their descendents as company CEOs, they are more likely to have greater emotional attachment and commitment to the company, and a longer 
investment horizon. Their study found that the firms' competitive advantage dominates when founding families are in control, whereas extraction of private benefits prevails when the family heirs are in charged. Nevertheless, according to Burkart et al. (2003), the patterns and structure of family firms and their characteristics varies across countries. Burkart et al. (2003, p. 2168) states that:

In the United States, founders often hire professional managers early on. By the time a founder retires, his family retains only marginal ownership. In such Berle and Means (1932) corporations, professional managers exercise nearly full control. In Western Europe, significant ownership typically stays with the family after the founder retires. His children either hire a manager, as in BMW or Fiat, or run the firm themselves, as in Peugeot. In emerging markets, both management and ownership tend to stay with the family when the founder retires.

Therefore, in an emerging market like Malaysia, the question of whether there are differences between founder and non-founder family firms is not as important as in the US. Thus, this study does not examine whether family firms are managed by their founders or heirs/ descendants.

\subsection{Measurement of Corporate Governance Variables}

This section presents the measures of the corporate governance variables used in the study. In accordance with the hypotheses developed in Section 4.3.2, the proxies for seven corporate governance variables: audit committee size, audit committee independence, audit committee meeting, audit committee financial expertise, board size, board independence and CEO duality, are explained in subsections 4.7.1 to 4.7.7. 


\subsubsection{Audit Committee Size}

In Malaysia, the stock exchange listing requirements require all publicly listed companies to form an audit committee and appoint at least three members from the board of directors (Bursa Malaysia, 2005). Previous studies such as Yang and Krishnan (2005) and Lin et al. (2006) show that a larger audit committee is related to less management of quarterly earnings and fewer occurrences of earnings restatements. Yang and Krishnan (2005) use the number of directors on the audit committee as the proxy for audit committee size, while Lin et al. (2006) use a binary variable to distinguish between large and small audit committees. In Lin et al. (2006), audit committees that have at least four members are coded as 1, indicating a large committee, otherwise, 0. Following Yang and Krishnan (2005), the present study measures the size of the audit committee (ACSIZE) by the total number of audit committee members.

\subsubsection{Audit Committee Independence}

The Bursa Malaysia Listing Requirements stipulate that a majority of the audit committee members must be independent directors. This is because independent directors are perceived to be able to provide more objective and effective monitoring. Existing studies, which show that a more independent audit committee is more effective in performing its oversight role and ensuring high quality of financial reporting, use several proxies to measure audit committee independence. 
Persons (2005) and Abbott et al. (2004) use a binary variable to represent audit committee independence. The binary variable is coded 1 if all of the audit committee members are independent and 0 otherwise. Bédard et al. (2004) measures the independence of audit committee using two dummy variables. The first dummy variable is coded 1 when the audit committee is composed of more than $50 \%$ but less than $100 \%$ nonrelated outside directors and 0 otherwise; while the second dummy variable is coded 1 if the audit committee is composed solely of nonrelated outside directors and 0 otherwise. Bradbury et al.(2006) measures audit committee independence by the proportion of independent directors. This measure is also used in Klein et al. (2002), along with two other proxies based on majority and full independence of audit committee. Similar to Bradbury et al.(2006) and Klein et al. (2002), this study measures audit committee independence (ACIND) as the proportion of independent audit committee members.

\subsubsection{Audit Committee Meeting Frequency}

Audit committee meetings represent the time devoted by audit committee members to monitoring the company's management and financial affairs. Menon and Williams (1994) highlight that audit committees that do not meet or meet only once are unlikely to be effective monitors, whereas audit committees that have more frequent meetings exert more serious effort into overseeing management. The Malaysian Code on Corporate Governance (2007) suggests that audit committees should meet regularly. The revised code states that audit committee meetings should be attended by the finance director, the head of internal audit and a representative of the 
company's external auditors, while the other board members may only attend audit committee meetings upon invitation. The code also states that the audit committee should have meetings with the external auditors at least twice a year without the presence of executive board members so as to encourage free and honest exchange of views and opinions between the parties.

Previous studies use the exact number of yearly audit committee meetings or a binary variable to represent the frequency of the meetings. For example, Abbott et al. (2004) measure the level of committee activity using a binary variable taking the value of one if the audit committee held more than four meetings a year, otherwise, 0 . The threshold of four meetings a year is based on the recommendation of the National Association of Corporate Directors (1999), PricewaterhouseCoopers/IIA (2000) and

the Blue Ribbon Committee (1999). Other studies such as Bédard et al. (2004), Vafeas (2005), Karamanou and Vafeas (2005), Larcker et al. (2007) and Mangena and Tauringana (2008) measure the frequency of audit committee meetings as the total number of meetings in a year. Drawing on prior studies, this study measures audit committee meeting (ACMEET) as the number of meetings that a company's audit committee has in an accounting year.

\subsubsection{Audit Committee Financial Expertise}

The revised Malaysian Code on Corporate Governance (2007) recommends that all members of the audit committee should be financially literate and at least one audit committee member should be a member of an accounting association or body. The 
code also specifies that all audit committee members should be able to read, analyse and interpret financial statements so that they are able to effectively discharge their functions. The recommendation that the audit committee have at least one director with membership of an accounting association or body is in line with one of the Bursa Malaysia listing requirements. The listing requirement states that publicly listed companies must have an audit committee with at least one member with financial expertise, who is a member of the Malaysian Institute of Accountants (MIA) or possesses sufficient accounting experience and qualification, or is deemed "financially literate" by Bursa Malaysia. According to the Bursa Malaysia Corporate Governance Guide (2009), audit committee financially literacy refers to the ability to (i) read and understand financial statements, including a company's balance sheet, income statement and cash flow statements, (ii) analyse financial statements and ask pertinent questions about the company's operations against internal controls and risk factors, and (iii) understand and interpret the application of approved accounting standards.

In this study, the audit committee financial expertise variable, ACFIN, is measured as the proportion of audit committee directors who qualify as financial experts.A financial expert is defined as a director with working experience in accounting, auditing, or finance, and is a member of a local or overseas accounting association/body. 


\subsubsection{Board Size}

In Malaysia, the minimum number of directors on a board is specified in the Company's Act 1965 as three, while the maximum number of directors on a board is set at 15 under one of the Bursa Malaysia listing requirements. The Malaysian Code of Corporate Governance (2000) does not suggest an optimum board size for companies. However, the Code stresses that every board should examine its size, and determine the impact of the number upon its effectiveness. According to the Bursa Malaysia Corporate Governance Guide (2009), when determining the number of seats on a board, a company should consider the evolving circumstances and need of the company in terms of its size, scope and geography; and the need to achieve an appropriate balance of executive and non-executive directors and the independence of the directors to ensure that no individual or group of individuals could dominate decision-making. The guide also suggests that companies should consider other issues such as whether the director/s represent the interests of certain shareholders or groups of shareholders, whether the director/s have the technical know-how or experience in the relevant industry, and whether the board reflect a diversity of professional experience, race and gender. As in prior studies (e.g. Mak and Kusnadi, 2005; Vafeas, 2005; Yermack, 1996), this study uses the number of directors at the end of the financial year to measure board size (BODSIZE).

\subsubsection{Board Independence}

According to the Malaysian Code on Corporate Governance (2007), a company's board should include a balance of executive directors, and nonexecutive directors including those that are independent, such that no individual or small group of 
individuals can dominate the board's decision making. It is compulsory for a listed company to ensure that at least two directors or one-third of the board (whichever is higher) are independent directors ${ }^{23}$. The independent directors are expected to strengthen the role of board by bringing an unbiased opinion that non-independent directors cannot provide (Bursa Malaysia, 2009, p. 21). The Bursa Malaysia Corporate Governance Guide states that:

Independent directors are essential for protecting the interests of minority shareholders and can make significant contributions to a company's decision making by bringing in the quality of detached impartiality. Since an independent director has no conflict of interest in the discharge of his duties, he ought to approach any approval that is being sought at board level for a transaction or any matter with a watchful eye and with an inquiring mind.

I define board independence according to Paragraph 1.01 of the Bursa Malaysia Listing Requirements (Bursa Malaysia, 2005), which refers to the proportion of directors who are independent of management and free from any business or other relationship (e.g. family relationship) that could interfere with the exercise of independent judgment. In short, other than not being an executive director, an independent director does not own any shares in the company and does not have any relationship with any major shareholders, officers and executive directors in the company. The board independence (BODIND) is measured as the proportion of independent directors.

${ }^{23}$ Paragraph 15.02 of the Bursa Malaysia Listing Requirements. 


\subsubsection{CEO Duality}

The Malaysian Code on Corporate Governance (2007) does not encourage a company to appoint its CEO as the board chairman. The code specifies that there should be a clearly accepted division of responsibilities at the head of the company to ensure a balance of power and authority. Thus the role of CEO and chairman should be clearly separated $^{24}$. This is so that no one individual has unfettered power of decision making. The stock exchange (Bursa Malaysia) also recommends that an independent non-executive director be appointed as the chairman to provide balance to the influence of the company's CEO. However, in a situation where a company's CEO is also the chairman, it is recommended that the board of directors demonstrate strong independence in their decision-making. The decision to combine the roles of the CEO and chairman should also be explained in the annual report (Securities Commission, 2007).This study uses a dummy variable for CEO duality (DUALITY), taking the value one if the firm's chairman also performs the role of CEO, otherwise zero.

\subsection{Control Variables}

Dechow and Dichev (2002) explain that accrual quality could be jointly determined by a number of firm characteristics, such as a firm's business model and the operating environment. Specifically, they document that accrual quality is positively associated with firm size, and negatively associated with the variability of cash flows from operations, the variability of sales revenue, the length of the operating cycle and the frequency of reporting negative earnings. Their findings are consistent with existing

\footnotetext{
${ }^{24}$ Paragraph 4.18 the Malaysia Code on Corporate Governance (2007).
} 
theories, evidence and intuition. For example, accrual quality is higher in large firms as they have more stable and predictable operations, and a more diversified portfolio which results in smaller estimation errors. Higher variability of cash flows from operations and sales and longer operating cycles indicate more uncertainties, and a more volatile operating environment. Thus, a greater use of approximation and estimation, a higher probability of estimation error, and therefore lower quality of accruals. Similarly, firms that report frequent negative earnings are more likely to have lower accrual quality as an accrual made in response to negative shocks in earnings are likely to involve substantial estimation errors (Dechow and Dichev, 2002). In addition to the firms characteristics, Francis et al. (2004) include other intrinsic factors shown in previous research to influence earnings quality, via, lower intensity of intangibles and higher capital intensity.

Following Dechow and Dichev (2002) and Francis et al. (2004), this study controls for the factors that could potentially influence a firm's accrual quality. It is expected that the quality of accruals is positively associated with firm size (SIZE) and capital intensity (CAPINT); and negatively associated with volatility of cash flow from operations $(C F O V A R)$, volatility of sales revenue (SALESVAR), the operating cycle (OCYCLE), reporting of negative earnings (LOSS), and intangible asset intensity (ININT).

It is widely accepted that highly reputable auditors provide higher quality work than do other auditors (DeAngelo, 1981). According to Krishnan (2003), since auditors 
with a larger client base have a bigger reputation to lose, they would perform a higher quality of audit, therefore resulting in a higher quality of reported earnings. Prior studies suggest that high quality external auditors are associated with higher quality of financial statements as they are able to forestall insiders' incentives from exploiting accounting-based contractual constraints and are (i) less likely to allow earnings management (Ashbaugh, LaFond, and Mayhew, 2003; Becker, Defond, Jiambalvo, and Subramanyam, 1998; DeFond and Jiambalvo, 1994; Francis, Maydew, and Sparks, 1999; Frankel, Johnson, and Nelson, 2002; Gul, Lynn, and Tsui, 2002), and (ii) more likely to detect accounting error (DeFond and Jiambalvo, 1991). To control for the effect of external auditor quality, this study uses a dummy variable for auditor quality (BIG4), taking the value 1 if the firm was audited by a Big 4 auditor, otherwise 0.

Previous studies have also found that other firms characteristics such as firm growth (Johnson et al., 2002), financial distress (Burgstahler and Dichev, 1997; Dechow et al., 1996; Saleh and Ahmed, 2005) and tightness of debt constraints (Carlson and Bathala, 1997; DeFond and Jiambalvo, 1994; Jaggi and Lee, 2002; Sweeney, 1994) may affect the quality of earnings. However, the results of these studies are mixed.

According to Summers and Sweeney (1998), unethical managers are motivated to misstate financial statements when growth slows or reverses, to maintain a firm's consistent growth. Therefore, firms with lower rate of growth are more likely to be associated with lower earnings quality. In contrast, AlNajjar and Riahi-Belkaoui 
(2001) show that earnings management, measured by discretionary accruals, is higher in high growth firms, consistent with the political cost hypothesis of Watts and Zimmerman (1978).

Rosner (2003) and García-Lara et al. (2009) show that financially distressed firms are more likely to manipulate earnings before bankruptcy. Distressed firms are motivated by a desire to conceal signs of distress, leading them to manipulate earnings upwards (Rosner, 2003), in an attempt to pass through what management perceived as being a temporary bad period (García-Lara et al., 2009). Conversely, several studies have found that distressed firms do not manage earnings upward (DeAngelo, DeAngelo, and Skinner, 1994; Saleh and Ahmed, 2005), as managers prefer to disclose the firm's financial troubles to show their willingness to deal with them (DeAngelo et al., 1994), or to obtain consideration from labour unions and assistance from the government (García-Lara et al., 2009). DeFond and Jiambalvo (1994) show that managers of firms with tight debt constraints have incentives to increase income using discretionary accruals to avoid debt covenant violation. However, Becker et al. (1998) find that leverage is negatively associated with the absolute value of discretionary accruals. This could be due to the fact that the presence of debt-holders offers additional monitoring of managerial activities. As external capital providers, debt-holders have the incentive and ability to monitor firm activity to protect their invested principal (Larcker et al., 2007). 
Based on the empirical evidence on the association between firm's characteristics and earnings quality, this study include firm's growth (GROWTH), financial distress (DISTRESS), and tightness of debt constraints (LEVERAGE) as additional control variables. However, as shown in Table 4.2, no specific signs are predicted for these control variables.

The control variables are measured as follows. Firm size, (SIZE), is measured as the $\log$ of average total assets. Volatility of cash flows from operation, (CFOVAR), is proxied by the standard deviation of the firm's cash flow from operations scaled by total assets, over a lag of a six year period. Volatility of sales, (SALESVAR), is calculated as the standard deviation of the firm's sales revenue scaled by total assets, over a lag of a six year period. Operating cycle, (OPCYCLE), is the sum of days accounts receivable and sum of days inventory divided by 30 . The reporting of negative earnings, (LOSS), is a dummy variable taking the value of 1 if the firm reported negative earnings at the end of the financial year, otherwise, 0. Intangible intensity, (ININT), equals the ratio of $\mathrm{R} \& \mathrm{D}$ and advertising expenses to total sales revenue with any missing values of $R \& D$ and advertising expenses set to zero. Capital intensity (CAPINT) is measured as the ratio of the net book value of plant, property and equipment to total assets. Growth (GROWTH) equals the market-to book ratio, calculated as the end-of-year share price divided by book value per share. Tightness of debt constraints (LEVERAGE) equals the ratio of total debt to total assets, measured as the end of year total debt divide by total assets. Firm's financial distress (DISTRESS) is a dummy variable taking the value 1 if the sample firm 
experiences financial distress during the financial year, otherwise 0 . To identify whether a firm is financially distressed during the period, each firm's Z-Score is calculated using the Altman (1968) model. A firm with an average Z-Score of below 1.81 is considered to be financially distressed ${ }^{25}$.

\subsection{Regression Models}

\subsubsection{Direct Effect of Family Influence and Corporate Governance Variables on} Earnings Quality.

To test the hypotheses of this study, several multiple regression analysis are performed using ordinary least square regressions. As explained in the previous section, the models employ the absolute value of residuals from the modified Dechow and Dichev (2002) cross-sectional accrual quality model, multiplied by negative one, as a proxy for accrual quality (AQUALITY). This measure represents the extent of accrual quality, where higher AQUALITY implies higher accrual quality. The following multiple regression model is used to test the Hypothesis 1 and Hypothesis $2:$

$$
\begin{aligned}
\operatorname{AQUALITY}_{i, t} & =\beta_{0}+\beta_{1} \text { FAMILY }_{i, t}+\beta_{2} \text { ACSIZE }_{i, t}+\beta_{3} \text { ACIND }_{i, t}+\beta_{4} \text { ACMEET }_{i, t} \\
& +\beta_{5} \text { ACFIN }_{i, t}+\beta_{6} \text { BODSIZE }_{i, t}+\beta_{7} \text { BODIND }_{i, t}+\beta_{8} \text { DUALITY }_{i, t}
\end{aligned}
$$

${ }^{25}$ Altman Z-Scores are calculated annually using the following formula: $(1.2 \mathrm{x}$ working capital / total assets $)+$ $(1.4 \mathrm{x}$ retained earnings/ total assets $)+(3.3 \mathrm{x}$ EBIT/total aseests $)+(0.6 \mathrm{x}$ market capitalisation $)+(0.999 \mathrm{x}$ sales/total assets). According to Altman (1968), firms with a Z-Score below 1.81 are likely to fall into bankruptcy within two years. 


$$
\begin{aligned}
& +\beta_{9} \text { BIG }_{i, t}+\beta_{10} \text { GROWTH }_{i, t}+\beta_{11} \text { LEVERAGE }_{i, t}+\beta_{12} \text { SIZE }_{i, t} \\
& +\beta_{13} \text { OOSS }_{i, t}+\beta_{14} \text { SALESVAR }_{i, t}+\beta_{15} \text { CAPINT }_{i, t} \\
& +\beta_{16} \text { OPCYCLE }_{i, t}+\beta_{17} \text { CFOVAR }_{i, t}+\beta_{18} \text { INTINT }_{i, t} \\
& +\beta_{19} \text { DISTRESS }_{i, t}+\varepsilon_{i, t}
\end{aligned}
$$

where:

$A Q U A L I T Y_{i, t}=$ additive inverse of the absolute value of residuals from the modified Dechow and Dichev (2002) cross-sectional series model;

FAMILY $_{i, t}=$ dummy variable taking the value 1 if the family members own more than 20 percent of the firm's shares, and two or more members of the controlling family are appointed as directors, otherwise 0 ;

$A_{C S I Z E} \quad=$ number of audit committee members;

$A$ CIND $_{i, t} \quad=$ proportion of independent directors on the audit committee;

$A C M E E T_{i, t} \quad=$ number of audit committee meetings during the financial year;

$\operatorname{ACFIN}_{i, t}=$ number of audit committee members with financial expertise; BODSIZE $_{i, t}=$ number of board members;

$B O D I N D_{i, t}=$ proportion of independent directors on the board;

$\operatorname{DUALITY}_{i, t}=$ dummy variable taking the value 1 if the firm's CEO is the Chairman of the Board of Directors, otherwise 0;

$B I G 4_{i, t} \quad=$ a dummy variable, taking the value 1 if the firm was audited by a Big 4 auditor, otherwise 0;

$\mathrm{GROWTH}_{i, t} \quad=$ end-of-year share price divided by book value per share; 
LEVERAGE $E_{i, t}=$ total debt divided by total assets at the end of the financial year;

$S_{I Z E_{i, t}}=\log$ of total assets at the end of the financial year;

$\operatorname{LOSS}_{i, t} \quad=$ a dummy variable taking the value of 1 if the firm reported negative earnings at the end of the financial year, otherwise, 0 ;

$\operatorname{SALESVAR}_{i, t}=$ standard deviation of sales revenue for a lag of six-year period;

CAPINT $_{i, t}=$ ratio of net book value of property, plant and equipment to total assets at the end of financial year;

$O P C Y C L E_{i, t}=$ sum of days accounts receivable and sum of days inventory divided by 30 ;

CFOVAR $_{i, t}=$ standard deviation of cash flows from operation during a lag sixyear period;

$I N T I N T_{i, t}=$ ratio of reported R\&D and advertising expenses to total sales revenue at the end of financial year;

$\operatorname{DISTRESS}_{i, t}=$ a dummy variable, taking the value 1 if the firm's Altman Z Score signaled financial distress, otherwise 0 ;

In equation (4.3), the coefficient for FAMILY, $\left(\beta_{1}\right)$, signals the difference between earnings quality of family firms and nonfamily firms. If the coefficient is significantly positive (negative), family firms have significantly higher (lower) earnings quality than nonfamily firms. A significant positive or negative coefficient for FAMILY, $\left(\beta_{1}\right)$, suggests rejection of the null hypotheses $\left(\mathrm{H}_{1}\right)$, that there is no difference between earnings quality of family and nonfamily firms. The coefficients of ACSIZE $\left(\beta_{2}\right), \operatorname{ACIND}\left(\beta_{3}\right), \operatorname{ACMEET}\left(\beta_{4}\right)$, ACFIN $\left(\beta_{5}\right)$, BODSIZE $\left(\beta_{6}\right)$, BODIND 
$\left(\beta_{7}\right)$ and DUALITY $\left(\beta_{8}\right)$, show whether these corporate governance variables are associated with earnings quality. For example, a significant positive (negative) coefficient of ACSIZE, $\left(\beta_{2}\right)$ indicates that a bigger (smaller) audit committee size is associated with higher (lower) earnings quality. Based on the argument in Sections 4.3 and 4.8, the expected relationship between AQUALITY and the independent variables are illustrated in Table 4.2. Significant positive coefficients on ACSIZE, $\left(\beta_{2}\right), A C I N D\left(\beta_{3}\right), A C M E E T\left(\beta_{4}\right), A C F I N\left(\beta_{5}\right)$ and BODIND $\left(\beta_{7}\right)$ suggest support for hypotheses $\mathrm{H}_{2 \mathrm{~A}}, \mathrm{H}_{2 \mathrm{~B}}, \mathrm{H}_{2 \mathrm{C}}, \mathrm{H}_{2 \mathrm{D}}$ and $\mathrm{H}_{2 \mathrm{~F}}$, respectively. While, significant negative coefficients of BODSIZE $\left(\beta_{6}\right)$ and DUALITY $\left(\beta_{8}\right)$ will support hypotheses $\mathrm{H}_{2 \mathrm{E}}$ and $\mathrm{H}_{2 \mathrm{G}}$, respectively.

Table 4.2: Expected Relations between Explanatory Variables and Earnings Quality

\begin{tabular}{lll}
\hline Explanatory Variables & Expected Sign & Earnings Quality \\
\hline Family Firms & $+/-$ & Undetermined \\
Corporate Governance Variables & & \\
Audit Committee Size & + & Higher earnings quality \\
Audit Committee Independence & + & Higher earnings quality \\
Audit Committee Meeting & + & Higher earnings quality \\
Audit Committee Financial Expertise & + & Higher earnings quality \\
Board Size & - & Lower earnings quality \\
Board Independence & + & Higher earnings quality \\
CEO Duality & - & Lower earnings quality \\
Other Control Variables & & \\
Audited by Big4 & + & Higher earnings quality \\
Growth & $+/-$ & Undetermined \\
Leverage & $+/-$ & Undetermined \\
Firm Size & + & Higher earnings quality \\
Reporting Losses & - & Lower earnings quality \\
Sales Variability & - & Lower earnings quality \\
Capital Intensity & + & Higher earnings quality \\
Operating Cycle & - & Lower earnings quality \\
Cash Flows Variability & - & Lower earnings quality \\
Intangible Intensity & - & Lower earnings quality \\
Financial Distress & $+/-$ & Undetermined \\
\hline
\end{tabular}


4.9.2 Mitigating Effect of Family Influence on the Relationship between Corporate Governance and Earnings Quality

To examine the effect of family firms on the association between corporate governance and earnings quality, this study partitions the full sample into two subsamples of firms. One subsample consists of family firms, in which family members own more than 20 percent of firm's shares, and two or more members of the controlling family are appointed as directors. The other subsample consists of nonfamily firms, which are firms that do not meet the criteria of family firms. Hypothesis $\mathrm{H}_{3}$ is tested by estimating equation (4.3) for the two sub-samples separately after the deletion of the family variable $(F A M I L Y)$. It is expected that the relationship between corporate governance and earnings quality is stronger in nonfamily firms sample, compared to family firms.

I also test the third hypothesis relating to whether the corporate governance-earnings quality relationship in family firms is weaker than in nonfamily firms, by estimating another ordinary least square regression using equation (4.4) as follows:

$$
\begin{aligned}
\text { AQUALITY }_{i, t} & =\beta_{0}+\beta_{1} \text { FAMILY }_{i, t}+\beta_{2} \text { ACSIZE }_{i, t}+\beta_{3} \text { ACIND }_{i, t}+\beta_{4} \text { ACMEET }_{i, t} \\
& +\beta_{5} \text { ACFIN }_{i, t}+\beta_{6} \text { BODSIZE }_{i, t}+\beta_{7} \text { BODIND }_{i, t}+\beta_{8} \text { DUALITY }_{i, t} \\
& +\beta_{9} \text { ACSIZE*FAMILY }_{i, t}+\beta_{10} \text { ACIND*FAMILY }_{i, t} \\
& +\beta_{11} \text { ACMEET }^{*} F A M I L Y_{i, t}+\beta_{12} \text { ACFIN }^{*} F A M I L Y_{i, t} \\
& +\beta_{13} \text { BODSIZE }^{*} F A M I L Y_{i, t}+\beta_{14} B O D I N D * F A M I L Y_{i, t} \\
& +\beta_{15} \text { DUALITY*FAMILY } Y_{i, t}+\beta_{16} B I G 4_{i, t}+\beta_{17} G R O W T H_{i, t}
\end{aligned}
$$




$$
\begin{aligned}
& +\beta_{18} \text { LEVERAGE }_{i, t}+\beta_{19} \text { SIZE }_{i, t}+\beta_{20} \text { LOSS }_{i, t}+\beta_{21} \text { SALESVAR }_{i, t} \\
& +\beta_{22} \text { CAPINT }_{i, t}+\beta_{23} \text { OPCYCLE }_{i, t}+\beta_{24} \text { CFOVAR }_{i, t}+\beta_{25} \operatorname{INTINT}_{i, t} \\
& +\beta_{126} \text { DISTRESS }_{i, t}+\varepsilon_{i, t}
\end{aligned}
$$

Equation (4.4) includes seven interaction variables of corporate governance measures and family firms. The variables are ACSIZE*FAMILY, ACIND*FAMILY, ACMEET*FAMILY, ACFIN*FAMILY, BODSIZE*FAMILY, BODIND*FAMILY and DUALITY*FAMILY. These variables measure the incremental effect of each corporate governance-earnings quality relationship in family firms. If the coefficient of ACSIZE*FAMILY, ACIND*FAMILY, ACMEET*FAMILY, ACFIN*FAMILY and $B O D I N D^{*} F A M I L Y$ is positive, and the coefficient of BODSIZE*FAMILY and $D U A L I T Y^{*} F A M I L Y$ is negative; family firms have significantly stronger corporate governance-earnings quality relationships than in nonfamily firms. On the other hand, a significant opposite sign on the coefficients would indicate weaker corporate governance-earnings quality relationships in family firms.

\subsection{Sensitivity and Robustness Test}

Several sensitivity and robustness tests are carried out in this study. This includes correcting t-statistics using the method introduced by White (1980) to adjust for potential heteroscedasticity problems, using industry and year dummies to control for industry and year fixed effects, adopting Fama \& MacBeth regressions to mitigate potential time-series correlations of pooled data, and using alternative measures for the family firm and earnings quality. 


\subsubsection{Controlling for Potential Heteroscedasticity Problem}

According to Chai and Hayes (2008), among the assumptions of the ordinary least squares OLS regression model, homoscedasticity is a rather stringent one that is unlikely to hold in many applied settings. The variance of the dependent variable is often related to the values of one or more explanatory variables, resulting in heteroscedasticity (Chai and Hayes, 2008). Therefore, White (1980) corrected tstatistics are estimated to account for potential heteroscedasticity problem.

\subsubsection{Controlling for Potential Time-series Correlations of Pooled Data}

As this study use panel data, in which 527 companies are observed over a six-year period of 2003-2008, there is the possibility of serial correlation of residuals. Fama and French (2002) highlighted the inference problem due to correlation of the residuals across firms in panel data. They emphasise that when the residuals are correlated across years, the cross-correlation problem and the bias in the standard errors of regression slopes arise. To tackle this problem, controls for industry and year fixed effects on earnings quality are included in equation (4.3) and the equation is re-estimated. This study creates industry dummies, based on the Malaysian Stock Exchange industry classification, and year dummies as in equation (4.5).

$$
\begin{aligned}
\operatorname{AQUALITY}_{i, t} & =\beta_{0}+\beta_{1} \text { FAMILY }_{i, t}+\beta_{2} \text { ACSIZE }_{i, t}+\beta_{3} \text { ACIND }_{i, t}+\beta_{4} \text { ACMEET }_{i, t} \\
& +\beta_{5} \text { ACFIN }_{i, t}+\beta_{6} \text { BODSIZE }_{i, t}+\beta_{7} \text { BODIND }_{i, t}+\beta_{8} \text { DUALITY }_{i, t} \\
& +\beta_{9} \text { BIGS }_{i, t}+\beta_{10} \text { GROWTH }_{i, t}+\beta_{11} \text { LEVERAGE }_{i, t}+\beta_{12} \text { SIZE }_{i, t} \\
& +\beta_{13} \text { OOSS }_{i, t}+\beta_{14} \text { SALESVAR }_{i, t}+\beta_{15} \text { CAPINT }_{i, t} \\
& +\beta_{16} \text { OPCYCLE }_{i, t}+\beta_{17} \text { CFOVAR }_{i, t}+\beta_{18} \text { INTINT }_{i, t}
\end{aligned}
$$




$$
+\beta_{19} \text { DISTRESS } S_{i, t}+\text { Industry Dummies }+ \text { Year Dummies }+\varepsilon_{i, t}
$$

Accordingly, the control for industry and year fixed effect are also included in equation (4.4) to ensure that the result of the mitigating effect of family on the relationship between corporate governance and earnings quality does not suffer from the problem of serially correlated residuals. The relationship is re-estimated using equation (4.6), in which the industry and year dummies are included to control for industry and year fixed effects.

$$
\begin{aligned}
& \operatorname{AQUALITY}_{i, t}=\beta_{0}+\beta_{1} \text { FAMILY }_{i, t}+\beta_{2} \text { ACSIZE }_{i, t}+\beta_{3} \text { ACIND }_{i, t}+\beta_{4} A C M E E T_{i, t} \\
& +\beta_{5} \text { ACFIN }_{i, t}+\beta_{6} \text { BODSIZE }_{i, t}+\beta_{7} \text { BODIND }_{i, t}+\beta_{8} \text { DUALITY }_{i, t} \\
& +\beta_{9} A C S I Z E^{*} F A M I L Y_{i, t}+\beta_{10} A C I N D * F A M I L Y_{i, t} \\
& +\beta_{11} A C M E E T^{*} F A M I L Y_{i, t}+\beta_{12} A C F I N * F A M I L Y_{i, t} \\
& +\beta_{13} \text { BODSIZE* FAMILY }_{i, t}+\beta_{14} B O D I N D^{*} F A M I L Y_{i, t} \\
& +\beta_{15} D_{U A L I T Y}^{*} F A M I L Y_{i, t}+\beta_{16} B I G 4_{i, t}+\beta_{17} G R O W T H_{i, t} \\
& +\beta_{18} L_{E V E R A G E}+\beta_{19} \operatorname{SIZE}_{i, t}+\beta_{20} \operatorname{LOSS}_{i, t}+\beta_{21} \operatorname{SALESVAR}_{i, t} \\
& +\beta_{22} \text { CAPINT }_{i, t}+\beta_{23} \text { OPCYCLE }_{i, t}+\beta_{24} \text { CFOVAR }_{i, t}+\beta_{25} \text { INTINT }_{i, t} \\
& +\beta_{26} \text { DISTRESS }_{i, t}+\text { Industry Dummies }+ \text { Year Dummies }+\varepsilon_{i, t}
\end{aligned}
$$

As an alternative to mitigate potential time-series correlations of pooled data, the study also performs the Fama and MacBeth (1973) regression approach as in the Anderson and Reeb (2003a) and Wang (2006) studies. 


\subsubsection{Alternative Measures of Earnings Quality}

The accrual quality measure used in this study is based on the absolute value of the residuals generated from the Dechow and Dichev (2002) accrual quality model with some modifications as suggested by McNichols (2002). The difference between the original Dechow and Dichev (2002) model and the modified version is that the original model captures both intentional and unintentional accrual estimation error by management (Hermanns, 2006). The modified version of the model captures only the intentional accrual estimation error by including some variables from Jones' (1991) earnings management model, viz, the PPE and $\triangle \mathrm{REV}$. To check whether the results are robust to alternative measures of accrual quality, estimation of equations (4.3) to (4.6) is repeated using an alternative accrual quality measures, the absolute value of residuals from the original Dechow and Dichev (2002) model.

Similar to the previous approach, regression (4.1) is performed cross-sectionally for each industry and year based on the Bursa Malaysia industry classification to estimate the accrual quality values for each firm from the year 2003 to 2008 . The absolute value of the residuals estimated from the original Dechow and Dichev (2002) model are then multiplied by negative 1 to represent the alternative measure for accrual quality (AQ2). A higher value of $A Q 2$ reflects better quality of earnings.

\subsubsection{Alternative Measures of Family Influence}

As explained in Section 4.6, existing studies such as Chau and Gray (2010) and Chu and Cheah (2006), identify family firms based on common shares held by the 
founding family and their relatives. Other studies, such as Haniffa and Cooke (2002), Ghazali and Weetman (2006) measure family dominance based on the control of family members over the firm's board. In Wang (2006), family ownership and family control of the board are separated and identified as two different variables.

Based on the existing studies, alternative measures for family firms are used to provide additional evidence on the effect of family firms on the quality of earnings and the corporate governance-earnings quality relationship. First, the variable FAMILY is replaced by FAM20, a binary variable for family firms that is coded one if family members own more than $20 \%$ of the firm's shares, and coded zero otherwise. This variable, (FAM20), measures the effect of family firms due to ownership of the firm's equity by family members, regardless of control through the board of directors. Second, the variable $F A M I L Y$ is replaced by $F A M B O D$, a binary variable for family firms that is coded one if there are two or more family members on the board, and coded zero otherwise. This variable, $(F A M B O D)$, measures the effect of family firms due to control of the board by family members irrespective of the level of family common stock ownership. Wang (2006) justifies this variable on the basis that family influence exerted on the firm, represented by voting power, may go beyond the percentage of shares owned by family members.

\subsection{Summary and Conclusions}

This chapter presents the theoretical framework for the study and explains the expected links between family firms, corporate governance and earnings quality based on agency theory. With reference to the theoretical framework, this chapter 
develops the hypotheses predicting the relationship between the three main variables. First, it is hypothesised that there is a relationship between earnings quality and family firms. Second, the study hypothesises that better quality of earnings is associated with stronger corporate governance; as manifest by bigger size of the audit committee, a more independent audit committee, more frequent audit committee meetings, greater audit committee financial expertise, smaller size of the board of directors, a more independent board of directors, and the absence of CEO duality. Third, it is hypothesised that family influence mitigates the relationship between corporate governance and earnings quality.

This chapter also describes the research methodology; including the sample selection process, the measures for the dependent, independent and control variables, and the quantitative analyses used to test the hypotheses. The results of the application of this research methodology are reported in the next chapter. 


\section{CHAPTER FIVE: RESULTS AND DISCUSSIONS}

\subsection{Introduction}

This chapter presents the results of the study. Section 5.2 presents the descriptive statistics of the sample. The correlation analysis of the variables examined in the study is presented in Section 5.3. Section 5.4 provides the findings from the analysis of the direct effect of family ownership and corporate governance variables on earnings quality. The findings from the analysis the mitigating effect of family ownership effect on the relationship between corporate governance and earnings quality are reported in Section 5.5. Section 5.6 outlines the results from the sensitivity analyses. Section 5.7 provides a discussion of the analyses.

\subsection{Descriptive Statistics}

Table 5.1 reports the mean values of earnings quality (AQUALITY), which is measured as the additive inverse of the absolute value of residuals from industryspecific yearly regression of the modified Dechow and Dichev (2000) accrual quality model, for each industry and year during the period under study. In general, the mean value of earnings quality does not vary greatly between the years. The highest (lowest) mean value of AQUALITY occurred in 2006 (2004), with a value of -0.054 (-

0.067). In particular, the year 2006 recorded the highest mean of AQUALITY for all industries, except for the properties sector. Across industries, the table shows that on 
average, the plantation sector had the highest earnings quality, while the technology sector had the lowest quality of earnings during the sample period.

Table 5.1: Description of Earnings Quality by Industry and Year

\begin{tabular}{lccccccr}
\hline \multirow{2}{*}{ Industry } & \multicolumn{7}{c}{ Mean values of Earnings Quality (AQUALITY) } \\
\cline { 2 - 8 } & 2003 & 2004 & 2005 & 2006 & 2007 & 2008 & Total Period \\
\hline Construction & -0.077 & -0.067 & -0.058 & -0.051 & -0.076 & -0.060 & -0.065 \\
Consumer Product & -0.052 & -0.059 & -0.057 & -0.049 & -0.057 & -0.052 & -0.054 \\
Industrial Product & -0.069 & -0.074 & -0.056 & -0.055 & -0.066 & -0.056 & -0.063 \\
Plantation & -0.045 & -0.063 & -0.052 & -0.029 & -0.044 & -0.043 & -0.046 \\
Properties & -0.061 & -0.049 & -0.049 & -0.066 & -0.061 & -0.062 & -0.058 \\
Technology & -0.085 & -0.111 & -0.069 & -0.064 & -0.057 & -0.080 & -0.078 \\
Trading/Services & -0.068 & -0.061 & -0.059 & -0.056 & -0.079 & -0.073 & -0.066 \\
All companies & -0.065 & -0.067 & -0.056 & -0.054 & -0.065 & -0.060 & -0.061 \\
\hline
\end{tabular}

Note: The sample covered a total of 527 companies. Earnings quality (AQUALITY) is measured as the additive inverse of the absolute value of residual from the cross-sectional modified Dechow and Dichev (2002) accrual quality model over 2003-2008. Companies are categorised based on the Bursa Malaysia industry classification.

With regard to family and nonfamily firms, the industry distribution based on Bursa Malaysia industry classification and description of earnings quality are shown in Table 5.2. Overall, the table shows that both groups of firms in the sample have similar industry distributions. The proportion of family firms is higher than nonfamily firms in all sectors, other than properties, technology and trading/services. In total, the percentage of family firms in the sample is $51.23 \%$. This is slightly lower than the percentage reported in previous studies on family firms in Malaysia ${ }^{26}$. However, this difference is to be expected as the current study use stricter criteria for family firm identification.

\footnotetext{
${ }^{26}$ Claessens et al. (2000) shows that $57.5 \%$ and $67.2 \%$ of publicly listed firms in Malaysia as of the end of fiscal year 1996 are owned by family based on $10 \%$ and $20 \%$ equity ownership, respectively. Similarly, Cheung and Chan (2004) states that based on 20 percent cut off level, 67.2\% of total market capitalization in Malaysia is controlled by family.
} 
Table 5.2: Description of Family and Nonfamily Firms by Industry

\begin{tabular}{|c|c|c|c|c|c|c|c|}
\hline \multirow[t]{3}{*}{ Industry } & \multicolumn{3}{|c|}{$\begin{array}{l}\text { Description of Family and } \\
\text { Nonfamily Firms by Industry }\end{array}$} & \multicolumn{4}{|c|}{$\begin{array}{c}\text { Earnings Quality (AQUALITY) of } \\
\text { Family and Nonfamily Firms }\end{array}$} \\
\hline & \multirow{2}{*}{$\begin{array}{l}\text { No. of } \\
\text { nonfamily } \\
\text { firms }\end{array}$} & \multirow{2}{*}{$\begin{array}{l}\text { No. of } \\
\text { family } \\
\text { firms }\end{array}$} & \multirow{2}{*}{$\begin{array}{l}\text { Percentage } \\
\text { of family } \\
\text { firms }\end{array}$} & \multicolumn{2}{|c|}{ Nonfamily firms } & \multicolumn{2}{|c|}{ Family firms } \\
\hline & & & & Mean & Median & Mean & Median \\
\hline Construction & 15 & 20 & 57.14 & -0.061 & -0.050 & -0.068 & -0.049 \\
\hline Consumer Product & 36 & 58 & 61.70 & -0.065 & -0.045 & -0.048 & -0.037 \\
\hline Industrial Product & 90 & 96 & 51.61 & -0.070 & -0.045 & -0.055 & -0.037 \\
\hline Plantation & 11 & 17 & 60.71 & -0.048 & -0.034 & -0.045 & -0.031 \\
\hline Properties & 33 & 32 & 49.23 & -0.065 & -0.041 & -0.051 & -0.035 \\
\hline Technology & 19 & 10 & 34.48 & -0.082 & -0.067 & -0.070 & -0.059 \\
\hline Trading/Services & 53 & 37 & 41.11 & -0.070 & -0.047 & -0.060 & -0.040 \\
\hline Total & 257 & 270 & 51.23 & -0.068 & -0.046 & -0.055 & -0.039 \\
\hline
\end{tabular}

Note: The sample covered a total of 527 companies. The study divided the sample into two groups: family and nonfamily firms. Family firms are firms firm where family members own more than 20 percent of the firm's shares, and two or more members of the controlling family are appointed as directors. Earnings quality (AQUALITY) is measured as the additive inverse of the absolute value of residual from modified Dechow and Dichev (2002) cross-sectional accrual quality model over 2003-2008. Companies are categorised based on the Bursa Malaysia industry classification.

Table 5.2 illustrates that the overall mean of earnings quality in family firms is higher than nonfamily firm. Across the full sample, earnings quality (AQUALITY) in family firms has a mean of -0.055 and a median of -0.039 , while AQUALITY in nonfamily firms has a mean of -0.068 and a median of -0.046 . The table also shows that the quality of earnings in family firms is on average higher than nonfamily firms in all industries except for the construction sector where it is marginally lower. Specifically, AQUALITY in family (nonfamily) firms within the construction industry has a mean of $-0.068(-0.061)$ and a median of $-0.049(-0.050)$, respectively. The mean of AQUALITY for family (nonfamily) firms is $-0.048(-0.065)$ in consumer product, $-0.055(-0.070)$ in industrial product, $-0.045(-0.048)$ in plantation, $-0.051(-$ $0.065)$ in property, $-0.070(-0.082)$ in technology and $-0.060 \quad(-0.070)$ in trading/services, respectively. 
Panel A of Table 5.3 presents the summary statistics of all continuous variables, and univariate analysis of mean differences in earnings quality, corporate governance and firm's characteristics between family and nonfamily firms. As reported in the table, the mean and median value of earnings quality (AQUALITY) is -0.061 and -0.042 respectively. The univariate analysis shows that the mean difference between the earnings quality of family and nonfamily firms is statistically different at 0.01 percent level.

With respect to the corporate governance variables, Table 5.3 shows that not all variables have a statistically different mean values between family and nonfamily firms. For the size of audit committee (ACSIZE), the descriptive statistics shows the smallest and biggest audit committee of firms in the sample has 2 and 10 members, respectively. On average, the audit committee of firms in the sample has 3 to 4 members. The same range applies to the average size of audit committee in family and nonfamily firms. While the smallest audit committee in both types of firms have 2 members, the biggest audit committee in family (nonfamily firms) has 6 (10) members. However, the test of mean difference between the size of audit committee in family and nonfamily firms shows no significant result.

In terms of audit committee independence (ACIND), surprisingly, not all companies meet the Bursa Malaysia listing requirement that a majority of the audit committee members should be independent. As reported in Table 5.3, the minimum and average percentage of independent audit committee members in the sample is $25 \%$ and $74 \%$, 
respectively. The table also shows that the mean proportion of independent audit committee in family firms is marginally lower than in nonfamily firms but this difference is significant. This indicates that audit committees members in family firms are more likely to have a greater proportion of non-independent audit committee members, signaling the potential involvement of family members in the audit committee.

Table 5.3 shows that the average number of audit committee meetings (ACMEET) is 4 to 5 times in year. Both family and nonfamily data sets show that the minimum number of audit committee meeting is 0 . But, the maximum number of audit committee meetings in a year is 10 for family firms and 13 for nonfamily firms. The analysis of the mean difference between the number of audit committee meetings in the two groups of firms shows a significantly higher average in nonfamily firms.

With regards to audit committee financial expertise $(A C F I N)$, the table shows that the companies in the sample range from those without any financial expert in the audit committee to those with $100 \%$ financial experts in the audit committee. Both family and nonfamily groups show similar distributions. The average proportions of financial expertise in audit committee in the full sample, family and nonfamily are $37.7 \%, 37.3 \%$ and $38.1 \%$ respectively. There is no significant difference between the mean values of the proportion of audit committee financial experts in family and nonfamily firms. 
Table 5.3: Summary Statistics and Analysis of Mean Differences in Earnings Quality, Corporate Governance and Firm Characteristics between Family and Nonfamily Firms

\begin{tabular}{|c|c|c|c|c|c|}
\hline \multicolumn{6}{|c|}{ Panel A: Continuous variables } \\
\hline & & \multicolumn{3}{|c|}{ Firms } & \multirow{2}{*}{$\begin{array}{l}\text { Mean difference (2)-(3) } \\
\text { (t-value) }\end{array}$} \\
\hline & & All (1) & Non-family (2) & Family (3) & \\
\hline \multirow[t]{5}{*}{ AQUALITY } & Mean & -0.061 & -0.068 & -0.055 & $-0.013 *$ \\
\hline & Median & -0.042 & -0.046 & -0.039 & $(-5.917)$ \\
\hline & SD & 0.063 & 0.070 & 0.055 & \\
\hline & Min & -0.429 & -0.429 & -0.387 & \\
\hline & Max & -0.000 & -0.000 & -0.000 & \\
\hline \multirow[t]{5}{*}{ ACSIZE } & Mean & 3.433 & 3.429 & 3.436 & -0.008 \\
\hline & Median & 3.000 & 3.000 & 3.000 & $(-0.327)$ \\
\hline & SD & 0.666 & 0.698 & 0.635 & \\
\hline & Min & 2.000 & 2.000 & 2.000 & \\
\hline & Max & 10.000 & 10.000 & 6.000 & \\
\hline \multirow[t]{5}{*}{$A C I N D$} & Mean & 0.740 & 0.745 & 0.735 & $0.010 * *$ \\
\hline & Median & 0.670 & 0.670 & 0.670 & $(2.366)$ \\
\hline & SD & 0.121 & 0.126 & 0.116 & \\
\hline & Min & 0.250 & 0.330 & 0.250 & \\
\hline & Max & 1.000 & 1.000 & 1.000 & \\
\hline \multirow[t]{5}{*}{ ACMEET } & Mean & 4.690 & 4.754 & 4.630 & $0.123 *$ \\
\hline & Median & 5.000 & 5.000 & 5.000 & (3.178) \\
\hline & SD & 1.092 & 1.171 & 1.009 & \\
\hline & Min & 0.000 & 0.000 & 0.000 & \\
\hline & Max & 13.000 & 13.000 & 10.000 & \\
\hline \multirow[t]{5}{*}{$A C F I N$} & Mean & 0.377 & 0.381 & 0.373 & 0.009 \\
\hline & Median & 0.330 & 0.330 & 0.330 & (1.345) \\
\hline & SD & 0.184 & 0.186 & 0.182 & \\
\hline & Min & 0.000 & 0.000 & 0.000 & \\
\hline & Max & 1.000 & 1.000 & 1.000 & \\
\hline \multirow[t]{5}{*}{ BODSIZE } & Mean & 7.415 & 7.265 & 7.557 & $-0.292 *$ \\
\hline & Median & 7.000 & 7.000 & 7.000 & $(-4.412)$ \\
\hline & SD & 1.863 & 1.857 & 1.858 & \\
\hline & Min & 3.000 & 3.000 & 4.000 & \\
\hline & Max & 15.000 & 14.000 & 15.000 & \\
\hline \multirow[t]{5}{*}{ BODIND } & Mean & 0.420 & 0.431 & 0.409 & $0.022 *$ \\
\hline & Median & 0.400 & 0.400 & 0.400 & (5.830) \\
\hline & $\mathrm{SD}$ & 0.107 & 0.117 & 0.096 & \\
\hline & Min & 0.143 & 0.167 & 0.143 & \\
\hline & Max & 1.000 & 1.000 & 1.000 & \\
\hline
\end{tabular}




\begin{tabular}{|c|c|c|c|c|c|}
\hline \multirow[t]{5}{*}{ GROWTH } & Mean & 1.020 & 1.094 & 0.949 & $0.144^{*}$ \\
\hline & Median & 0.770 & 0.820 & 0.740 & (5.099) \\
\hline & SD & 0.798 & 0.856 & 0.733 & \\
\hline & Min & 0.170 & 0.170 & 0.170 & \\
\hline & Max & 3.640 & 3.640 & 3.640 & \\
\hline \multirow[t]{5}{*}{ LEVERAGE } & Mean & 0.225 & 0.225 & 0.225 & 0.000 \\
\hline & Median & 0.210 & 0.217 & 0.204 & $(0.012)$ \\
\hline & SD & 0.175 & 0.172 & 0.179 & \\
\hline & Min & 0.000 & 0.000 & 0.000 & \\
\hline & Max & 0.672 & 0.672 & 0.672 & \\
\hline \multirow[t]{5}{*}{ SIZE } & Mean & 8.453 & 8.473 & 8.433 & $0.040^{* *}$ \\
\hline & Median & 8.387 & 8.432 & 8.359 & (2.141) \\
\hline & $\mathrm{SD}$ & 0.524 & 0.555 & 0.491 & \\
\hline & Min & 7.496 & 7.496 & 7.496 & \\
\hline & Max & 9.930 & 9.930 & 9.930 & \\
\hline \multirow[t]{5}{*}{ SALESVAR } & Mean & 0.260 & 0.287 & 0.235 & $0.051^{*}$ \\
\hline & Median & 0.215 & 0.233 & 0.201 & (8.245) \\
\hline & SD & 0.177 & 0.198 & 0.150 & \\
\hline & Min & 0.043 & 0.043 & 0.043 & \\
\hline & Max & 1.003 & 1.003 & 1.003 & \\
\hline \multirow[t]{5}{*}{ CAPINT } & Mean & 0.385 & 0.371 & 0.399 & $-0.028 *$ \\
\hline & Median & 0.383 & 0.371 & 0.395 & $(-3.905)$ \\
\hline & SD & 0.202 & 0.204 & 0.199 & \\
\hline & Min & 0.000 & 0.000 & 0.000 & \\
\hline & Max & 0.955 & 0.942 & 0.955 & \\
\hline \multirow[t]{5}{*}{ OPCYCLE } & Mean & 0.320 & 0.332 & 0.309 & 0.023 \\
\hline & Median & 0.196 & 0.181 & 0.206 & (1.385) \\
\hline & SD & 0.460 & 0.497 & 0.421 & \\
\hline & Min & 0.000 & 0.000 & 0.000 & \\
\hline & Max & 2.693 & 2.693 & 2.693 & \\
\hline \multirow[t]{5}{*}{ CFOVAR } & Mean & 0.059 & 0.063 & 0.055 & $0.008^{*}$ \\
\hline & Median & 0.048 & 0.052 & 0.044 & (5.032) \\
\hline & SD & 0.045 & 0.048 & 0.042 & \\
\hline & Min & 0.006 & 0.006 & 0.006 & \\
\hline & Max & 0.264 & 0.264 & 0.264 & \\
\hline \multirow[t]{5}{*}{ INTINT } & Mean & 0.022 & 0.020 & 0.025 & -0.005 \\
\hline & Median & 0.000 & 0.000 & 0.000 & $(-1.256)$ \\
\hline & SD & 0.108 & 0.103 & 0.113 & \\
\hline & Min & 0.000 & 0.000 & 0.000 & \\
\hline & Max & 0.682 & 0.682 & 0.682 & \\
\hline
\end{tabular}




\begin{tabular}{|c|c|c|c|c|c|c|c|c|}
\hline \multicolumn{8}{|c|}{ Panel B: Dichotomous Variables } & \multirow{3}{*}{$\begin{array}{c}\text { Mean } \\
\text { difference } \\
(2)-(3) \\
\text { (t-value) }\end{array}$} \\
\hline & & \multicolumn{2}{|c|}{ All (1) } & \multicolumn{2}{|c|}{ Family (3) } & \multicolumn{2}{|c|}{ Nonfamily (2) } & \\
\hline & & 1 & 0 & 1 & 0 & 1 & 0 & \\
\hline \multirow[t]{2}{*}{ DUALITY } & Frequency & 472 & 2,690 & 264 & 1,356 & 208 & 1,334 & $-0.028 * *$ \\
\hline & Percentage & 14.93 & 85.07 & 16.30 & 83.70 & 13.49 & 86.51 & $(-2.215)$ \\
\hline \multirow[t]{2}{*}{ BIG4 } & Frequency & 2004 & 1158 & 1084 & 536 & 920 & 622 & $-0.073^{*}$ \\
\hline & Percentage & 63.38 & 36.62 & 66.91 & 33.09 & 59.66 & 40.34 & $(-4.241)$ \\
\hline \multirow[t]{2}{*}{ LOSS } & Frequency & 736 & 2426 & 302 & 1318 & 434 & 1108 & $0.095^{*}$ \\
\hline & Percentage & 23.28 & 76.72 & 18.64 & 81.36 & 28.15 & 71.85 & $(6.359)$ \\
\hline \multirow[t]{2}{*}{ DISTRESS } & Frequency & 1363 & 1799 & 646 & 974 & 717 & 825 & $0.066^{*}$ \\
\hline & Percentage & 43.11 & 56.89 & 39.88 & 60.12 & 46.50 & 53.50 & (3.765) \\
\hline
\end{tabular}

Note: $*$ and $* *$ represents statistical significance at 0.01 and 0.05 levels, respectively. The sample covered a total of 527 companies over 2003-2008. Family firms are firms that have family members owning more than 20 percent of firm's shares and two or more members of the controlling family are appointed as directors. AQUALITY is the additive inverse of the absolute value of residual from modified Dechow and Dichev (2002) cross-sectional accrual quality model over 2003-2008. ACSIZE is the total number firm's audit committee members. ACIND is the proportion of independent audit committee members to the total number of audit committee members. ACMEET is the number of firm's audit committee meeting during the year financial year. $A C F I N$ is the proportion of audit committee members with financial/accounting expertise to the total number of audit committee members. BODSIZE is the total number of directors in the board. BODIND is the proportion of independent directors to the total number of board of directors. GROWTH equals the end-of-year share price divided by book value per share. LEVERAGE is measured as end of the year total debt divide by total assets. SIZE is the log of total assets. SALESVAR is the standard deviation of sales revenue over a lag of six years period. CAPINT is a measure of capital intensity, equal to the ratio of net book value of property, plant and equipment to total assets. OPCYCLE is the sum of days account receivable and sum of days inventory divided by 30. CFOVAR is the standard deviation of cash flows from operation over a lag of six years period. INTINT is a measure of intangible intensity, equal to the ratio of reported $R \& D$ and advertising expenses to total sales revenue. DUALITY is a dummy variable, taking the value 1 if the firm's chairman also performs the role of CEO, otherwise 0. BIG4 is a dummy variable, taking the value 1 if the firm was audited by a Big 4 auditor, otherwise 0 . LOSS is a dummy variable taking the value of 1 if firm reported negative earnings at the end of financial year, otherwise, 0. DISTRESS is a dummy variable, taking the value 1 if the firm's Altman Z Score signalled financial distress, otherwise 0 .

Descriptive statistics for the board size variables (BODSIZE) and board independence (BODIND) show that on average, companies in the full sample have between 7 to 8 directors on the board, on average, with $42 \%$ of the directors being independent. The analysis of mean difference of BODSIZE and BODIND between family and nonfamily firms reveals that family firms have higher mean values for BODSIZE, but lower mean values for BODIND. This is logical since in family firms, family members are usually appointed as company directors, making the overall size of 
board of directors in family firms bigger, compared to nonfamily firms. The involvement of family members as company directors also contributes to relatively lower proportion of independent directors in these firms.

As regards the continuous control variables, Panel A shows that firms in the sample have mean (median) market to book ratio of $1.02(0.770)$; the mean (median) of firms leverage, as measured by total debts to total assets is $22.5 \%(21.0 \%)$, with a standard deviation of 0.175 ; the mean (median) of firm size, as measured by log of total assets is 8.453 (8.387) with a standard deviation of 0.524 ; the mean values for sales variability, capital intensity, operating cycle, cash flows variability and intangible intensity are $0.26,0.385,0.320,0.059$ and 0.022 respectively. The test of mean difference shows that there are significant difference between the mean values of firm growth, size, sales variability, capital intensity and cash flows variability between family and nonfamily firms.

Panel B of Table 5.3 presents the descriptive statistics of dichotomous variables used in the study. The table shows that only $14.93 \%$ of the sample observations are characterised by CEO duality. Specifically, $16.30 \%$ of family firms and $13.49 \%$ of nonfamily firms have a chairman who is also the chief executive officer. This implies that for the majority of the sample firms, CEO and board chair positions are occupied by different individuals. In total, $63.38 \%$ firms in the sample are audited by Big4 companies. The percentage of firms audited by Big4 in family firms, 66.91\%, is slightly higher than for nonfamily firms, 59.66. Overall, $23.28 \%$ percent of the 
sample observations reported negative earnings (LOSS) and $43.11 \%$ are in financial distress during the six-year period of 2003-2008. Family firms recorded a lower frequency of reporting losses and lower percentage of firms in financial distress, compared to non family firms.

\subsection{Correlation Analysis of Variables}

To examine the correlation among the dependent and independent variables in the regression tests, a correlation analysis for all variables is performed, except for the year and industry dummies. According to Pallant (2007), a serious multi-collinearity problem might exists among independent variables if the univariate correlation coefficient is significant and greater than 0.7. The Pearson product momentum correlations and Spearman rank correlation coefficients are reported in Table 5.4. Although most correlations are statistically significant, the correlations are not large enough to prohibit the use of multivariate regression analysis. However, since a large number of independent variables are used in the regression tests, there are still possibilities of the independent variables being collectively correlated with other variables. The univariate Pearson and Spearman correlation results are not able to detect the collective multiple correlations (Berry and Feldman, 1985). Therefore, this study examines the variance inflation factors of variables used in the regression tests to determine if such multiple correlations exist between independent variables. The variance inflations factors, as shown in Table 5.5, are less than 10, indicating there is no serious multicollinearity problem. 
The correlation matrix in Table 5.4 shows that the various measures of family firms are all positively correlated with the measures of accrual quality. Thus family firm is associated with higher earnings quality. The degree of the correlations is in general consistent with those reported in Wang (2006).

The control variables, firm growth $(G R O W T H)$, firms size (SIZE), reporting of negative earnings (LOSS), sales variability (SALESVAR), capital intensity (CAPINT), operating cycle (OPCYCLE), cash flow variability (CFOVAR), and intangible intensity (INTINT) also show significant correlations with the dependent variable (AQUALITY). The sign of the significant correlations is consistent with the expected sign as noted in Table 4.2. Surprisingly, the corporate governance variables do not show significant correlations with earnings quality in the sample.

Consistent with the analysis of mean difference in the previous section, the correlation matrix in Table 5.4 shows that the family firm variable is significantly related to lower audit committee independence (ACIND), lower number of audit committee meetings (ACMEET), bigger board size (BODSIZE), lower board independence (BODIND), lower growth (GROWTH), smaller firm size (SIZE), lower sales variability (SALESVAR), higher capital intensity (CAPINT) and lower cash flow variability $(C F O V A R)$. The family firm variable is also found to be positively correlated with CEO duality (DUALITY) and appointment of Big4 auditors (BIG4) and negatively related to the reporting of negative earnings (LOSS). 
Table 5.4: Pearson and Spearman Correlation Matrix for Family, Corporate Governance and Control Variables

\begin{tabular}{|c|c|c|c|c|c|c|c|c|c|c|}
\hline & AQUALITY & $\mathrm{AQ} 2$ & FAMILY & FAM20 & FAMBOD & ACSIZE & ACIND & ACMEET & ACFIN & BODSIZE \\
\hline AQUALITY & & $0.820^{* *}$ & $0.088^{* *}$ & $0.062^{* *}$ & $0.078^{* *}$ & 0.014 & 0.012 & 0.027 & -0.010 & 0.000 \\
\hline $\mathrm{AQ} 2$ & $0.919^{* *}$ & & $0.090^{* *}$ & $0.051^{* *}$ & $0.090^{* *}$ & $0.040^{*}$ & 0.023 & $.037^{*}$ & -0.029 & -0.004 \\
\hline FAMILY & $0.105^{* *}$ & $0.103^{* *}$ & & $0.599^{* *}$ & $0.874^{* *}$ & 0.022 & -0.021 & $-0.040^{*}$ & $-0.036^{*}$ & $0.074^{* *}$ \\
\hline FAM20 & $0.066^{* *}$ & $0.063^{* *}$ & $0.599^{* *}$ & & $0.376^{* *}$ & $0.038^{*}$ & -0.024 & $0.040^{*}$ & 0.018 & $0.051^{* *}$ \\
\hline FAMBOD & $0.102^{* *}$ & $0.105^{* *}$ & $0.874^{* *}$ & $0.376^{* *}$ & & 0.030 & -0.018 & $-0.056^{* *}$ & $-0.042^{*}$ & $0.085^{* *}$ \\
\hline ACSIZE & 0.018 & 0.032 & 0.006 & 0.030 & 0.007 & & $0.245^{* *}$ & 0.035 & $-0.458^{* *}$ & $0.367^{* *}$ \\
\hline ACIND & 0.027 & 0.028 & $-0.042^{*}$ & $-0.042^{*}$ & $-0.043^{*}$ & $-0.081^{* *}$ & & 0.033 & $-0.079^{* *}$ & $0.167^{* *}$ \\
\hline ACMEET & 0.004 & 0.019 & $-0.056^{* *}$ & 0.029 & $-0.066^{* *}$ & 0.018 & $0.063^{* *}$ & & -0.029 & 0.001 \\
\hline ACFIN & 0.001 & -0.010 & -0.024 & $0.043^{*}$ & -0.030 & $-0.285^{* *}$ & $0.043^{*}$ & -0.013 & & $-0.145^{* *}$ \\
\hline BODSIZE & 0.006 & 0.012 & $0.078^{* *}$ & $0.061^{* *}$ & $0.087^{* *}$ & $0.369^{* *}$ & $0.092^{* *}$ & 0.013 & $-0.076^{* *}$ & \\
\hline BODIND & -0.031 & -0.023 & $-0.103^{* *}$ & $-0.046^{*}$ & $-0.118^{* *}$ & $0.085^{* *}$ & $0.279^{* *}$ & $0.080^{* *}$ & $-0.066^{* *}$ & $-0.276^{* *}$ \\
\hline DUALITY & 0.013 & 0.019 & $0.039^{*}$ & $0.043^{*}$ & 0.027 & $-0.035^{*}$ & $-0.063^{* *}$ & 0.025 & $-0.048^{* *}$ & $-0.093^{* *}$ \\
\hline BIG4 & 0.014 & 0.009 & $0.075^{* *}$ & $0.046^{* *}$ & $0.056^{* *}$ & $0.037^{*}$ & $-0.047^{* *}$ & -0.017 & -0.022 & $0.042^{*}$ \\
\hline GROWTH & $-0.134^{* *}$ & $-0.151^{* *}$ & $-0.090^{* *}$ & $-0.113^{* *}$ & $-0.122^{* *}$ & 0.013 & $-0.039^{*}$ & $-0.060^{* *}$ & 0.019 & $0.050^{* *}$ \\
\hline LEVERAGE & -0.005 & -0.029 & 0.000 & -0.004 & 0.019 & $-0.050^{* *}$ & -0.026 & $0.047^{* *}$ & 0.017 & $-0.038^{*}$ \\
\hline SIZE & $0.056^{* *}$ & $0.071^{* *}$ & $-0.038^{*}$ & 0.000 & $-0.058^{* *}$ & 0.034 & $0.041^{*}$ & $0.215^{* *}$ & -0.029 & $0.116^{* *}$ \\
\hline LOSS & $-0.101^{* *}$ & $-0.118^{* * *}$ & $-0.112^{* *}$ & $-0.063^{* *}$ & $-0.091^{* *}$ & $-0.060^{* * *}$ & 0.031 & $0.038^{*}$ & $-0.043^{*}$ & $-0.166^{* * *}$ \\
\hline SALESVAR & $-0.124^{* *}$ & $-0.137^{* *}$ & $-0.145^{* *}$ & -0.031 & $-0.127^{* *}$ & $-0.071^{* *}$ & $0.056^{* *}$ & $0.103^{* *}$ & $-0.108^{* *}$ & $-0.097^{* *}$ \\
\hline CAPINT & $0.128^{* *}$ & $0.143^{* *}$ & $0.069^{* *}$ & $0.049^{* *}$ & $0.062^{* *}$ & $0.048^{* *}$ & $-0.088^{* *}$ & -0.035 & -0.005 & 0.030 \\
\hline OPCYCLE & $-0.040^{*}$ & $-0.042^{*}$ & -0.025 & -0.016 & 0.017 & $-0.036^{*}$ & 0.017 & 0.028 & 0.014 & $-0.067^{* *}$ \\
\hline CFOVAR & $-0.186^{* *}$ & $-0.197^{* *}$ & $-0.089^{* *}$ & $-0.073^{* *}$ & $-0.069^{* *}$ & 0.005 & $0.036^{*}$ & $-0.038^{*}$ & 0.001 & -0.002 \\
\hline INTINT & $-0.036^{*}$ & -0.030 & 0.022 & $0.039^{*}$ & -0.001 & $0.039^{*}$ & -0.032 & -0.005 & 0.011 & 0.023 \\
\hline DISTRESS & -0.021 & -0.016 & $-0.067^{* *}$ & -0.008 & $-0.049^{* *}$ & $-0.059^{* *}$ & 0.015 & $0.070^{* *}$ & 0.010 & $-0.076^{* *}$ \\
\hline
\end{tabular}

Note: $*$ and $* *$ represents statistical significance at 0.05 and 0.01 levels, respectively. Values in the below (above) diagonal are Pearson (Spearman) pairwise correlations. All variables are as defined in Table 5.3. 
Table 5.4: Pearson and Spearman Correlation Matrix for Family, Corporate Governance and Control Variables (con't)

\begin{tabular}{|c|c|c|c|c|c|c|c|c|c|c|}
\hline & BODIND & DUALITY & BIG4 & GROWTH & LEVERAGE & SIZE & LOSS & SALESVAR & CAPINT & OPCYCLE \\
\hline AQUALITY & -0.015 & 0.018 & 0.005 & $-0.100^{* *}$ & 0.015 & $0.068^{* *}$ & $-0.102^{* *}$ & $-0.093^{* *}$ & $0.138^{* *}$ & $-0.061^{* *}$ \\
\hline $\mathrm{AQ} 2$ & 0.000 & 0.021 & -0.009 & $-0.116^{* *}$ & -0.019 & $0.086^{* *}$ & $-0.142^{* *}$ & $-0.101^{* *}$ & $0.155^{* *}$ & $-0.071^{* *}$ \\
\hline FAMILY & $-0.079^{* *}$ & $0.039^{*}$ & $0.075^{* *}$ & $-0.075^{* *}$ & -0.006 & $-0.037^{*}$ & $-0.112^{* *}$ & $-0.112^{* *}$ & $0.070^{* *}$ & $0.047^{* *}$ \\
\hline FAM20 & -0.029 & $0.043^{*}$ & $0.046^{* *}$ & $-0.088^{* * *}$ & -0.006 & -0.006 & $-0.063^{* *}$ & -0.028 & $0.050^{* *}$ & $0.071^{* *}$ \\
\hline FAMBOD & $-0.098^{* *}$ & 0.027 & $0.056^{* *}$ & $-0.119^{* *}$ & 0.019 & $-0.056^{* *}$ & $-0.091^{* *}$ & $-0.099^{* *}$ & $0.066^{* *}$ & $0.091^{* *}$ \\
\hline ACSIZE & $0.117^{* *}$ & -0.026 & $0.047^{* *}$ & 0.023 & $-0.040^{*}$ & $0.045^{*}$ & $-0.064^{* *}$ & $-0.053^{* *}$ & $0.059^{* *}$ & 0.012 \\
\hline ACIND & $0.274^{* *}$ & $-0.058^{* *}$ & -0.034 & -0.028 & -0.016 & $0.069^{* *}$ & 0.014 & $0.047^{* *}$ & $-0.039^{*}$ & -0.007 \\
\hline ACMEET & $0.086^{* *}$ & 0.014 & -0.031 & $-0.078^{* * *}$ & $0.041^{*}$ & $0.139^{* *}$ & $0.061^{* *}$ & $0.102^{* * *}$ & $-0.058^{* *}$ & $0.035^{*}$ \\
\hline ACFIN & $-0.067^{* *}$ & -0.033 & $-0.037^{*}$ & 0.001 & -0.006 & $-0.048^{* *}$ & -0.019 & $-0.084^{* *}$ & -0.018 & $-0.036^{*}$ \\
\hline BODSIZE & $-0.255^{* *}$ & $-0.097^{* *}$ & $0.045^{*}$ & $0.062^{* *}$ & $-0.051^{* *}$ & $0.077^{* *}$ & $-0.164^{* *}$ & $-0.101^{* *}$ & 0.019 & -0.031 \\
\hline BODIND & & 0.011 & -0.022 & -0.016 & 0.013 & 0.031 & $0.091^{* *}$ & $0.128^{* *}$ & -0.013 & $-0.046^{* *}$ \\
\hline DUALITY & -0.007 & & 0.003 & -0.003 & 0.003 & 0.009 & -0.006 & 0.008 & $0.039^{*}$ & $-0.058^{* *}$ \\
\hline BIG4 & -0.028 & 0.003 & & 0.008 & -0.003 & $0.085^{* *}$ & $-0.063^{* *}$ & $-0.073^{* *}$ & $0.056^{* *}$ & -0.029 \\
\hline GROWTH & -0.024 & 0.007 & -0.004 & & $-0.142^{* *}$ & $-0.040^{*}$ & $-0.168^{* *}$ & 0.028 & $-0.110^{* *}$ & $-0.112^{* *}$ \\
\hline LEVERAGE & 0.016 & 0.004 & -0.007 & $-0.090^{* *}$ & & $0.227^{* *}$ & $0.206^{* *}$ & $0.060^{* *}$ & $0.194^{* *}$ & 0.030 \\
\hline SIZE & 0.005 & 0.012 & $0.091^{* *}$ & 0.000 & $0.216^{* *}$ & & $-0.215^{* *}$ & $0.066^{* *}$ & $0.065^{* *}$ & $-0.125^{* *}$ \\
\hline LOSS & $0.112^{* *}$ & -0.006 & $-0.063^{* *}$ & $-0.110^{* *}$ & $0.218^{* *}$ & $-0.206^{* *}$ & & $0.151^{* *}$ & $0.078^{* *}$ & $0.110^{* *}$ \\
\hline SALESVAR & $0.187^{* *}$ & -0.015 & $-0.100^{* *}$ & $0.041^{*}$ & 0.027 & $0.042^{*}$ & $0.170^{* *}$ & & $-0.073^{* *}$ & $0.110^{* *}$ \\
\hline CAPINT & -0.033 & 0.028 & $0.056^{* *}$ & $-0.117^{* *}$ & $0.186^{* *}$ & $0.079^{* *}$ & $0.082^{* *}$ & $-0.085^{* *}$ & & $-0.138^{* *}$ \\
\hline OPCYCLE & 0.005 & $-0.068^{* *}$ & $-0.065^{* *}$ & $-0.120^{* * *}$ & 0.007 & 0.010 & $0.144^{* *}$ & $0.269^{\text {** }}$ & -0.022 & \\
\hline CFOVAR & $0.039^{*}$ & $-0.073^{* *}$ & $-0.047^{* *}$ & $0.114^{* *}$ & -0.021 & $-0.165^{* *}$ & 0.006 & $0.173^{* *}$ & $-0.240^{* *}$ & -0.020 \\
\hline INTINT & -0.011 & $0.049^{* *}$ & 0.033 & $0.132^{* *}$ & -0.031 & $0.067^{* *}$ & $-0.051^{* *}$ & $-0.089^{* *}$ & 0.024 & $0.057^{* *}$ \\
\hline DISTRESS & $0.104^{* *}$ & -0.013 & $-0.097^{* *}$ & $-0.305^{\text {** }}$ & $0.514^{* *}$ & $0.084^{* *}$ & $0.383^{* *}$ & $0.177^{* *}$ & $0.237^{* *}$ & $0.146^{* *}$ \\
\hline
\end{tabular}

Note: * and ** represents statistical significance at 0.05 and 0.01 levels, respectively. Values in the below (above) diagonal are Pearson (Spearman) pairwise correlations. All variables are as defined in Table 5.3. 
Table 5.4: Pearson and Spearman Correlation Matrix for Family, Corporate Governance and Control Variables (con't)

\begin{tabular}{|c|c|c|c|}
\hline & CFOVAR & INTINT & DISTRESS \\
\hline AQUALITY & $-0.157^{* *}$ & -0.013 & -0.004 \\
\hline AQ2 & $-0.166^{* *}$ & -0.001 & -0.002 \\
\hline FAMILY & $-0.098^{* *}$ & 0.012 & $-0.067^{* *}$ \\
\hline FAM20 & $-0.076^{* *}$ & 0.026 & -0.008 \\
\hline FAMBOD & $-0.087^{* *}$ & -0.007 & $-0.049^{* *}$ \\
\hline ACSIZE & -0.032 & -0.003 & $-0.045^{*}$ \\
\hline ACIND & -0.011 & $-0.040^{*}$ & 0.016 \\
\hline ACMEET & $-0.053^{* *}$ & -0.009 & $0.083^{* *}$ \\
\hline ACFIN & 0.017 & 0.005 & 0.012 \\
\hline BODSIZE & 0.012 & 0.000 & $-0.086^{* *}$ \\
\hline BODIND & -0.017 & -0.019 & $0.090^{* * *}$ \\
\hline DUALITY & $-0.076^{* *}$ & $0.094^{* *}$ & -0.013 \\
\hline BIG4 & -0.035 & 0.024 & $-0.097^{* *}$ \\
\hline GROWTH & $0.142^{* *}$ & $0.107^{* *}$ & $-0.373^{* *}$ \\
\hline LEVERAGE & -0.011 & 0.007 & $0.518^{* * *}$ \\
\hline SIZE & $-0.188^{* *}$ & $0.091^{* *}$ & $0.086^{* *}$ \\
\hline LOSS & $-0.040^{*}$ & $-0.049^{* *}$ & $0.383^{* *}$ \\
\hline SALESVAR & $0.058^{* *}$ & $-0.090^{* *}$ & $0.180^{* *}$ \\
\hline CAPINT & $-0.232^{* *}$ & 0.020 & $0.232^{* *}$ \\
\hline OPCYCLE & -0.004 & 0.008 & $0.094^{* *}$ \\
\hline CFOVAR & & $-0.078^{* *}$ & $-0.122^{* * *}$ \\
\hline INTINT & -0.031 & & $-0.036^{*}$ \\
\hline DISTRESS & $-0.037^{*}$ & $-0.037^{*}$ & \\
\hline
\end{tabular}

(Spearman) pairwise correlations. All variables are as defined in Table 5.3. 
Table 5.5: Variance Inflation Factors of Variables Used in Regression Tests

\begin{tabular}{|c|c|c|c|c|c|c|}
\hline \multirow[b]{2}{*}{ Sample } & \multicolumn{3}{|c|}{ Equation (4.3) } & \multicolumn{3}{|c|}{ Equation (4.5) } \\
\hline & Full & Nonfamily & Family & Full & Nonfamily & Family \\
\hline ACSIZE & 1.38 & 1.37 & 1.37 & 1.40 & 1.40 & 1.40 \\
\hline$A C I N D$ & 1.19 & 1.19 & 1.19 & 1.34 & 1.34 & 1.34 \\
\hline ACMEET & 1.08 & 1.08 & 1.08 & 1.10 & 1.10 & 1.10 \\
\hline ACFIN & 1.12 & 1.12 & 1.12 & 1.14 & 1.13 & 1.13 \\
\hline BODSIZE & 1.45 & 1.44 & 1.44 & 1.47 & 1.46 & 1.46 \\
\hline BODIND & 1.36 & 1.35 & 1.35 & 1.37 & 1.37 & 1.37 \\
\hline DUALITY & 1.03 & 1.03 & 1.03 & 1.04 & 1.04 & 1.04 \\
\hline FAMILY & 1.07 & & & 1.10 & & \\
\hline BIG4 & 1.04 & 1.04 & 1.04 & 1.05 & 1.05 & 1.05 \\
\hline GROWTH & 1.20 & 1.18 & 1.18 & 1.28 & 1.27 & 1.27 \\
\hline LEVERAGE & 1.48 & 1.47 & 1.47 & 1.28 & 1.27 & 1.27 \\
\hline SIZE & 1.28 & 1.27 & 1.27 & 1.51 & 1.50 & 1.50 \\
\hline LOSS & 1.34 & 1.33 & 1.33 & 1.35 & 1.34 & 1.34 \\
\hline SALESVAR & 1.29 & 1.28 & 1.28 & 1.33 & 1.32 & 1.32 \\
\hline CAPINT & 1.17 & 1.16 & 1.16 & 1.33 & 1.33 & 1.33 \\
\hline OPCYCLE & 1.15 & 1.15 & 1.15 & 1.21 & 1.21 & 1.21 \\
\hline CFOVAR & 1.15 & 1.14 & 1.14 & 1.17 & 1.17 & 1.17 \\
\hline INTINT & 1.05 & 1.05 & 1.05 & 1.10 & 1.10 & 1.10 \\
\hline DISTRESS & 1.80 & 1.79 & 1.79 & 1.88 & 1.88 & 1.88 \\
\hline$I N D \_1$ & & & & 3.46 & 3.46 & 3.46 \\
\hline$I N D \_2$ & & & & 4.55 & 4.53 & 4.53 \\
\hline$I N D \_3$ & & & & 1.95 & 1.95 & 1.95 \\
\hline$I N D \_4$ & & & & 2.79 & 2.78 & 2.78 \\
\hline$I N D \_5$ & & & & 1.93 & 1.91 & 1.91 \\
\hline$I N D \_6$ & & & & 3.18 & 3.16 & 3.16 \\
\hline$Y R \_2004$ & & & & 1.68 & 1.68 & 1.68 \\
\hline$Y R \_2005$ & & & & 1.71 & 1.71 & 1.71 \\
\hline$Y R \_2006$ & & & & 1.71 & 1.71 & 1.71 \\
\hline$Y R \_2007$ & & & & 1.76 & 1.76 & 1.76 \\
\hline$Y R \_2008$ & & & & 1.98 & 1.98 & 1.98 \\
\hline
\end{tabular}




\subsection{Multivariate Analysis on the Direct Effect of Family Influence and Corporate Governance Variables on Earnings Quality.}

Column 1 of Table 5.6 presents the results from the estimation of equation (4.3), where the quality of earnings (AQUALITY) is regressed on the measures for family firm (FAMILY), corporate governance and other control variables. The corporate governance variables are the size of audit committee (ACSIZE), audit committee independence (ACIND), audit committee meeting (ACMEET), audit committee financial expertise $(A C F I N)$, size of the board of directors (BODSIZE), board independence (BODIND) and CEO duality (DUALITY).

As explained in Section 4.5 in the previous chapter, earnings quality in this regression is estimated using the absolute value of residuals from the modified Dechow and Dichev (2002) cross-sectional accrual quality model. Three other regression results are also presented in Table 5.6. The second column shows the regression estimates of equation (4.3) after adjusting for heteroscedasticity using White's (1980) consistent covariance matrix, the third column presents the results of regression estimates after controlling for industry and year fixed effects that is in equation (4.5), and the fourth column presents the results of regression estimates of equation (4.3) using the Fama and MacBeth (1973) procedure to mitigate the potential time-series correlations of panel data.

The F-values from all four regression models are statistically significant at $1 \%$ level.

The adjusted $\mathrm{R}^{2}$ for the basic OLS, White adjusted, and Industry \& Year adjusted 
regressions is $8 \%$; while the adjusted $\mathrm{R}^{2}$ for Fama-MacBeth regression is $11 \%$. Even though the explanatory power of the models is low, they are higher than those reported in a study examining earnings quality and board independence in Malaysia by Abdullah and Nasir (2004) that report an $\mathrm{R}^{2}$ of $5.33 \%$. Other studies such as Rahman and Ali (2006) that examined earnings management and corporate governance in Malaysia, and Wang (2006) that examined abnormal accruals and family ownership in the US also reported similar values of $\mathrm{R}^{2}$, viz, $12.8 \%$ and $13 \%$ respectively.

The results from the basic regression reported in Table 5.6 show that the family firm variable $(F A M I L Y)$ has a significant positive association with earnings quality (AQUALITY) at $1 \%$ level with a t-statistics of 3.398. This indicates that the null hypothesis $\left(\mathrm{H}_{1}\right)$ that there is no difference between earnings quality in family and nonfamily firms is not supported. This result suggests that the influence of family in firms, through significant ownership of firms equity and control over firm board of directors, results in higher quality of earnings. The positive and significant relation between family influence and earnings quality is consistent with Wang (2006) findings on earnings quality of the US family firms. It supports the agency theory prediction based on the alignment effect of family. 
Table 5.6: Regression Results of Family Firms and Corporate Governance on Earnings Quality (Earnings Quality=AQUALITY).

\begin{tabular}{|c|c|c|c|c|c|c|c|c|}
\hline & \multicolumn{2}{|c|}{ Basic Regression } & \multicolumn{2}{|c|}{ White (1980) } & \multicolumn{2}{|c|}{$\begin{array}{c}\text { Industry \& } \\
\text { Year Effects }\end{array}$} & \multicolumn{2}{|c|}{$\begin{array}{c}\text { Fama \& MacBeth } \\
(1973)\end{array}$} \\
\hline & coeff & $t$-stat & coeff & white- $t$ & coeff & t-stat & coeff & $t$-stat \\
\hline INTERCEPT & $-0.076^{*}$ & -3.561 & $-0.076^{*}$ & -3.331 & $-0.073 *$ & -3.029 & $-0.080 * * *$ & -2.189 \\
\hline FAMILY & $0.008 *$ & 3.398 & $0.008^{*}$ & 3.356 & $0.007^{*}$ & 3.040 & $0.008^{*}$ & 4.733 \\
\hline ACSIZE & 0.002 & 1.283 & 0.002 & 1.318 & 0.002 & 0.883 & 0.002 & 1.281 \\
\hline$A C I N D$ & $0.029^{*}$ & 2.954 & $0.029^{*}$ & 3.326 & $0.031 *$ & 2.975 & 0.020 & 1.527 \\
\hline ACMEET & 0.000 & 0.284 & 0.000 & 0.265 & 0.000 & 0.483 & 0.001 & 0.358 \\
\hline$A C F I N$ & -0.001 & -0.230 & -0.001 & -0.235 & -0.003 & -0.419 & -0.002 & -0.431 \\
\hline BODSIZE & $-0.001 * *$ & -2.135 & $-0.001 * *$ & -2.039 & $-0.001 * *$ & -1.969 & $-0.001 * *$ & -2.793 \\
\hline BODIND & -0.015 & -1.293 & -0.015 & -1.219 & -0.015 & -1.296 & -0.014 & -0.818 \\
\hline DUALITY & -0.001 & -0.170 & -0.001 & -0.170 & 0.000 & 0.013 & -0.001 & -0.361 \\
\hline BIG4 & -0.002 & -0.960 & -0.002 & -0.963 & -0.002 & -0.800 & -0.002 & -1.204 \\
\hline GROWTH & $-0.009 *$ & -6.127 & $-0.009 *$ & -5.039 & $-0.009 *$ & -5.733 & $-0.007 * *$ & -3.120 \\
\hline LEVERAGE & 0.000 & 0.028 & 0.000 & 0.025 & 0.002 & 0.289 & 0.002 & 0.241 \\
\hline SIZE & 0.002 & 1.065 & 0.002 & 1.012 & 0.002 & 0.854 & 0.003 & 0.839 \\
\hline LOSS & $-0.013^{*}$ & -4.554 & $-0.013^{*}$ & -4.192 & $-0.013 *$ & -4.510 & $-0.013 * *$ & -3.946 \\
\hline SALESVAR & $-0.021 *$ & -3.079 & $-0.021 *$ & -2.611 & $-0.023 *$ & -3.332 & $-0.021 * * *$ & -2.111 \\
\hline CAPINT & $0.029 *$ & 5.032 & $0.029 *$ & 4.880 & $0.027^{*}$ & 4.331 & $0.030 * *$ & 3.303 \\
\hline OPCYCLE & -0.003 & -1.157 & -0.003 & -1.118 & -0.002 & -0.873 & -0.003 & -1.300 \\
\hline CFOVAR & $-0.189 *$ & -7.425 & $-0.189 *$ & -5.798 & $-0.187 *$ & -7.270 & $-0.196 *$ & -7.218 \\
\hline INTINT & $-0.022 * *$ & -2.141 & $-0.022 * * *$ & -1.724 & $-0.026 * *$ & -2.460 & $-0.025^{*}$ & -4.253 \\
\hline DISTRESS & -0.005 & -1.586 & -0.005 & -1.578 & -0.004 & -1.427 & -0.005 & -1.349 \\
\hline IND_l & & & & & 0.002 & 0.384 & & \\
\hline$I N D \_2$ & & & & & -0.004 & -0.901 & & \\
\hline IND_3 & & & & & 0.007 & 1.013 & & \\
\hline$I N D \_4$ & & & & & -0.004 & -0.682 & & \\
\hline$I N D \_5$ & & & & & -0.003 & -0.384 & & \\
\hline IND_6 & & & & & -0.005 & -1.079 & & \\
\hline$Y R \_2004$ & & & & & -0.003 & -0.710 & & \\
\hline$Y R \_2005$ & & & & & 0.005 & 1.401 & & \\
\hline$Y R \_2006$ & & & & & $0.007 * *$ & 1.986 & & \\
\hline$Y R \_2007$ & & & & & -0.002 & -0.421 & & \\
\hline$Y R \_2008$ & & & & & -0.000 & -0.098 & & \\
\hline $\operatorname{Adj.R2}$ & 0.08 & & 0.08 & & 0.08 & & 0.11 & \\
\hline$O b s$ & 3162 & & 3162 & & 3162 & & 3162 & \\
\hline$F$-stat & 14.716 & & 10.446 & & 10.045 & & 119.456 & \\
\hline
\end{tabular}

Note: ***,*** represents statistical significance at $0.01,0.05$ and 0.10 levels, respectively. IND_l is a dummy variable taking the value 1 if the firm is under the consumer product based on the Bursa Malaysia industry classification, otherwise, 0. IND_2 is a dummy variable taking the value 1 if the firm is under the industrial product based on the Bursa Malaysia industry classification, otherwise, 0. IND_3 is a dummy variable taking the value 1 if the firm is under the plantation sector based on the Bursa Malaysia industry classification, otherwise, 0. IND_4 is a dummy variable taking the value 1 if the firm is under the properties sector based on the Bursa Malaysia industry classification, otherwise, $0 . I N D \_5$ is a dummy variable taking the value 1 if the firm is under the technology sector based on the Bursa Malaysia industry classification, otherwise, 0. IND_6 is a dummy variable taking the value 1 if the firm is under the trading/services sector based on the Bursa Malaysia industry

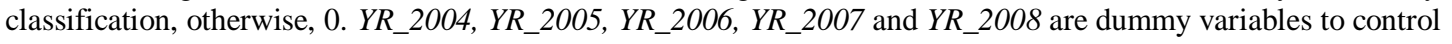
for year effect. All other variables are as defined in Table 5.3. 
Only two out of the seven corporate governance variables are found to be associated with earnings quality. Specifically, audit committee independence is found to be significantly positively associated with earnings quality at $1 \%$ level with t-statistics of 2.954, which supports hypothesis $\mathrm{H}_{2 \mathrm{~F}}$. This result indicates that firms with higher audit committee independence have higher quality of earnings. The result is consistent with the findings in the Bédard et al. (2004), Xie, at al. (2003) and Klein (2002) studies, which shows that audit committee independence promotes better quality of earnings by reducing earnings management. In line with Yermack (1996) and Vafeas (2000), the results also show that board size (BODSIZE) has a significant negative association with earnings quality at $5 \%$ level with a t-statistics of -2.135 , supporting hypothesis $\mathrm{H}_{2 \mathrm{E}}$. This suggests that firms with bigger board size have lower earnings quality.

The coefficients for the other corporate governance variables, ACSIZE, ACMEET, ACFIN, BODIND and DUALITY are not significant ( $\mathrm{p}>0.10)$, providing no evidence for the existence of associations between the variables and earnings quality (AQUALITY). This result shows that hypotheses $\mathrm{H}_{2 \mathrm{~A}}, \mathrm{H}_{2 \mathrm{~B}}, \mathrm{H}_{2 \mathrm{C}}, \mathrm{H}_{2 \mathrm{D}}$ and $\mathrm{H}_{2 \mathrm{G}}$ are not supported. The results also show that the control variables, firm growth (GROWTH), the reporting of negative earnings (LOSS), sales variability (SALESVAR), cash flows variability (CFOVAR) and intangible intensity (INTINT) have significant negative associations with earnings quality (AQUALITY). This suggests that firms with higher growth, negative earnings, higher sales variability, higher cash flows variability and higher intangible intensity have lower quality of earnings, and vice versa. In 
addition, as expected, capital intensity (CAPINT) has significant positive association with earnings quality, indicating that firms with higher capital intensity have higher quality of earnings. However, big 4 auditor (BIG4), firms leverage (LEVERAGE), firms size (SIZE), operating cycle (OPCYCLE) and financial distress (DISTRESS) do not have a significant association with earnings quality.

Column 2 in Table 5.6 summarises the regression estimates based on the procedure suggested by White (1980) to adjust for heteroscedasticity. The coefficients remain the same but, as expected, the $t$ values decrease. However, the results are qualitatively unchanged.

To control for the possibility of serial correlation of residuals in the pooled regression, equation (4.4) is estimated. In addition, the Fama-MacBeth (1973) procedure is also performed on equation (4.3). The results are presented in columns 3 and 4 of Table 5.6. The results remain qualitatively unchanged except that audit committee independence is not significant in the Fama-MacBeth (1973) regression.

\subsection{Multivariate Analysis on the Mitigating Effect of Family Influence on the Relationship between Corporate Governance and Earnings Quality}

To examine the effect of family firms on the association between corporate governance and earnings quality, this study partitions the full sample into two subsamples of firms. One subsample consists of family firms, in which family members own more than 20 percent of firm's shares, and two or more members of the 
controlling family are appointed as directors. The other subsample consists of nonfamily firms, which are firms that do not meet the criteria for being classified as a family firm. Hypothesis $\mathrm{H}_{3}$ is tested by estimating equation (4.3) for the two subsamples separately after deletion of the family firm variable (FAMILY). The results are reported in Section 5.5.1 and 5.5.2 below. The estimation results of equation (4.4), which tests the significance of the difference between the relationship of corporate governance and earnings quality in family and nonfamily firms are reported in Section 5.5.3.

\subsubsection{Corporate Governance and Earnings Quality Relationship in Nonfamily Firms}

Table 5.7 presents the regression estimates of the association between corporate governance variables and earnings quality for the four regression models using the nonfamily sample. The regression models are the same as used earlier for the full sample, that is, the basic regression, White (1980) model, controlling for industry and year effects, and the Fama-MacBeth (1973) model.

The results from the basic regression are reported in column 1 of Table 5.7. The results as for the full sample, audit committee independence (ACIND) and board size $(B O D S I Z E)$ are associated with earnings quality. However, in contrast to the full sample case for nonfamily firms, audit committee size (ACSIZE) is also positively associated with earnings quality. 
Table 5.7: Regression Results of Corporate Governance on Earnings Quality in Non-Family Firms (Earnings Quality=AQUALITY and FAMILY=0).

\begin{tabular}{|c|c|c|c|c|c|c|c|c|}
\hline & \multicolumn{2}{|c|}{ Basic Regression } & \multicolumn{2}{|c|}{ White (1980) } & \multicolumn{2}{|c|}{$\begin{array}{c}\text { Industry \& } \\
\text { Year Effects }\end{array}$} & \multicolumn{2}{|c|}{$\begin{array}{c}\text { Fama \& MacBeth } \\
\text { (1973) }\end{array}$} \\
\hline & coeff & $t$-stat & coeff & white- $t$ & coeff & $t$-stat & coeff & t-stat \\
\hline INTERCEPT & $-0.107 *$ & -3.209 & $-0.107 *$ & -3.048 & $-0.093 * *$ & -2.537 & -0.108 & -1.902 \\
\hline ACSIZE & $0.006 * *$ & 2.223 & $0.006 * *$ & 2.488 & $0.005^{* * *}$ & 1.805 & $0.006 * * *$ & 2.103 \\
\hline$A C I N D$ & $0.044 *$ & 2.901 & $0.044 *$ & 3.546 & $0.046^{*}$ & 2.855 & $0.045^{*}$ & 5.696 \\
\hline ACMEET & -0.000 & -0.095 & -0.000 & -0.085 & 0.000 & 0.003 & 0.000 & 0.177 \\
\hline ACFIN & -0.000 & -0.033 & -0.000 & -0.033 & -0.001 & -0.135 & -0.002 & -0.206 \\
\hline BODSIZE & $-0.002 * *$ & -2.055 & $-0.002 * *$ & -2.005 & $-0.002 * *$ & -1.965 & $-0.003 * *$ & -2.615 \\
\hline BODIND & -0.013 & -0.737 & -0.013 & -0.697 & -0.014 & -0.790 & -0.014 & -0.632 \\
\hline DUALITY & -0.003 & -0.671 & -0.003 & -0.647 & -0.003 & -0.626 & -0.003 & -0.685 \\
\hline BIG4 & -0.004 & -1.038 & -0.004 & -1.049 & -0.004 & -0.998 & -0.003 & -0.868 \\
\hline GROWTH & $-0.011 *$ & -5.116 & $-0.011 *$ & -4.349 & $-0.011 *$ & -4.863 & $-0.009 * *$ & -2.883 \\
\hline LEVERAGE & 0.010 & 0.792 & 0.010 & 0.715 & 0.016 & 1.241 & 0.014 & 1.453 \\
\hline SIZE & 0.005 & 1.329 & 0.005 & 1.266 & 0.004 & 1.018 & 0.005 & 0.745 \\
\hline$L O S S$ & $-0.011 * *$ & -2.557 & $-0.011 * *$ & -2.425 & $-0.011 * *$ & -2.538 & $-0.012 * * *$ & -2.264 \\
\hline SALESVAR & $-0.029 *$ & -2.917 & $-0.029 * *$ & -2.553 & $-0.033^{*}$ & -3.162 & $-0.030 * * *$ & -2.278 \\
\hline CAPINT & $0.021 * *$ & 2.363 & $0.021 * *$ & 2.354 & $0.020 * *$ & 2.025 & $0.021 * *$ & 3.183 \\
\hline OPCYCLE & -0.001 & -0.318 & -0.001 & -0.323 & 0.000 & 0.090 & -0.002 & -0.312 \\
\hline CFOVAR & $-0.158 *$ & -4.080 & $-0.158^{*}$ & -3.485 & $-0.154 *$ & -3.933 & $-0.167 *$ & -5.339 \\
\hline INTINT & -0.015 & -0.850 & -0.015 & -0.705 & -0.016 & -0.878 & -0.022 & -1.835 \\
\hline DISTRESS & $-0.010 * *$ & -2.206 & $-0.010 * *$ & -2.124 & $-0.011 * *$ & -2.256 & $-0.011 * *$ & -2.654 \\
\hline$I N D \_1$ & & & & & -0.004 & -0.446 & & \\
\hline$I N D \_2$ & & & & & -0.011 & -1.347 & & \\
\hline IND_3 & & & & & 0.009 & 0.732 & & \\
\hline$I N D \_4$ & & & & & -0.009 & -1.029 & & \\
\hline$I N D \_5$ & & & & & -0.008 & -0.762 & & \\
\hline IND_6 & & & & & -0.009 & -1.107 & & \\
\hline$Y R \_2004$ & & & & & -0.001 & -0.207 & & \\
\hline$Y R \_2005$ & & & & & 0.007 & 1.107 & & \\
\hline$Y R \_2006$ & & & & & $0.011 * * *$ & 1.831 & & \\
\hline$Y R \_2007$ & & & & & 0.001 & 0.131 & & \\
\hline$Y R \_2008$ & & & & & -0.001 & -0.091 & & \\
\hline $\operatorname{Adj.R2}$ & 0.06 & & 0.06 & & 0.07 & & 0.13 & \\
\hline Obs & 1542 & & 1542 & & 1542 & & 1542 & \\
\hline$F$-stat & 6.877 & & 5.572 & & 4.736 & & 174.820 & \\
\hline
\end{tabular}

Note: *, **, *** represents statistical significance at $0.01,0.05$ and 0.10 levels, respectively. All variables are as previously defined. 
The coefficients for the other corporate governance variables, ACMEET, ACFIN, BODIND and DUALITY remain insignificant $(\mathrm{p}>0.10)$, consistent with the results from the full sample. The same control variables remain significant except that intangibles intensity (INTINT) is no longer significant while DISTRESS becomes significant. Qualitatively similar results are obtained from estimation of the other three models.

\subsubsection{Corporate Governance and Earnings Quality Relationship in Family Firms}

Table 5.8 presents the regression estimates of the association between corporate governance variables and earnings quality for family firms, using each of the four regression models.

Unlike the results in the nonfamily sample, the regression estimates from all the models in Table 5.8 shows that none of the corporate governance variables, including ACSIZE, ACIND and BODSIZE, are significantly related to AQUALITY, other than ACSIZE being weakly significant $(\mathrm{p}=0.10)$ in the Fama-MacBeth (1973) estimation. This suggests that in family firms, various corporate governance mechanisms do not improve the quality of earnings. 
Table 5.8: Regression Results of Corporate Governance on Earnings Quality in Family Firms (Earnings Quality=AQUALITY and $F A M I L Y=1$ )

\begin{tabular}{|c|c|c|c|c|c|c|c|c|}
\hline & \multicolumn{2}{|c|}{ Basic Regression } & \multicolumn{2}{|c|}{ White (1980) } & \multicolumn{2}{|c|}{$\begin{array}{c}\text { Industry \& } \\
\text { Year Effects }\end{array}$} & \multicolumn{2}{|c|}{$\begin{array}{c}\text { Fama \& MacBeth } \\
(1973)\end{array}$} \\
\hline & coeff & $t$-stat & coeff & white- $t$ & coeff & $t$-stat & coeff & $t$-stat \\
\hline INTERCEPT & -0.024 & -0.890 & -0.024 & -0.883 & -0.028 & -0.889 & -0.023 & -1.131 \\
\hline ACSIZE & -0.002 & -0.978 & -0.002 & -0.932 & -0.003 & -1.107 & $-0.003 * * *$ & -2.275 \\
\hline$A C I N D$ & 0.013 & 1.024 & 0.013 & 1.021 & 0.013 & 1.011 & -0.005 & -0.231 \\
\hline ACMEET & 0.001 & 0.694 & 0.001 & 0.778 & 0.001 & 0.710 & 0.001 & 0.292 \\
\hline ACFIN & -0.004 & -0.534 & -0.004 & -0.581 & -0.005 & -0.608 & -0.003 & -0.684 \\
\hline BODSIZE & -0.001 & -0.798 & -0.001 & -0.750 & -0.000 & -0.541 & -0.001 & -0.842 \\
\hline BODIND & -0.018 & -1.189 & -0.018 & -1.160 & -0.018 & -1.132 & -0.015 & -1.479 \\
\hline DUALITY & 0.002 & 0.603 & 0.002 & 0.645 & 0.003 & 0.697 & 0.002 & 0.914 \\
\hline$B I G 4$ & -0.000 & -0.147 & -0.000 & -0.149 & -0.000 & -0.038 & -0.001 & -0.271 \\
\hline GROWTH & $-0.006^{*}$ & -3.247 & $-0.006^{*}$ & -2.691 & $-0.006^{*}$ & -2.796 & -0.005 & -1.795 \\
\hline LEVERAGE & -0.008 & -0.847 & -0.008 & -0.751 & -0.009 & -0.957 & -0.008 & -0.707 \\
\hline SIZE & -0.001 & -0.349 & -0.001 & -0.343 & -0.001 & -0.277 & 0.000 & 0.078 \\
\hline LOSS & $-0.016^{*}$ & -4.123 & $-0.016 *$ & -3.782 & $-0.016^{*}$ & -4.001 & $-0.017 *$ & -4.992 \\
\hline SALESVAR & -0.010 & -0.979 & -0.010 & -0.886 & -0.011 & -1.068 & -0.010 & -1.036 \\
\hline CAPINT & $0.034 *$ & 4.581 & $0.034 *$ & 4.387 & $0.029 *$ & 3.635 & $0.034 * *$ & 2.641 \\
\hline OPCYCLE & $-0.006 * * *$ & -1.687 & -0.006 & -1.552 & -0.005 & -1.576 & -0.005 & -1.733 \\
\hline CFOVAR & $-0.213^{*}$ & -6.364 & $-0.213^{*}$ & -4.586 & $-0.209 *$ & -6.136 & $-0.209 *$ & -5.925 \\
\hline INTINT & $-0.026 * *$ & -2.171 & -0.026 & -1.645 & $-0.031 * *$ & -2.523 & -0.026 & -1.560 \\
\hline DISTRESS & 0.001 & 0.407 & 0.001 & 0.425 & 0.003 & 0.843 & 0.003 & 0.440 \\
\hline$I N D \_1$ & & & & & 0.007 & 1.152 & & \\
\hline IND_2 & & & & & 0.002 & 0.304 & & \\
\hline$I N D \_3$ & & & & & 0.009 & 1.135 & & \\
\hline$I N D \_4$ & & & & & 0.001 & 0.110 & & \\
\hline$I N D \_5$ & & & & & -0.001 & -0.124 & & \\
\hline IND_6 & & & & & -0.001 & -0.212 & & \\
\hline$Y R \_2004$ & & & & & -0.004 & -0.880 & & \\
\hline$Y R \_2005$ & & & & & 0.004 & 0.904 & & \\
\hline$Y R \_2006$ & & & & & 0.004 & 0.961 & & \\
\hline$Y R \_2007$ & & & & & -0.004 & -0.910 & & \\
\hline$Y R \_2008$ & & & & & 0.000 & 0.091 & & \\
\hline Adj.R2 & 0.07 & & 0.07 & & 0.07 & & 0.14 & \\
\hline Obs & 1620 & & 1620 & & 1620 & & 1620 & \\
\hline$F$-stat & 8.137 & & 5.066 & & 5.470 & & 60.849 & \\
\hline
\end{tabular}

Note: $* * *, * * *$ represents statistical significance at $0.01,0.05$ and 0.10 levels, respectively. All variables are as previously defined.

\subsubsection{The Interaction Effect of Family Influence and Corporate Governance on}

\section{Earnings Quality}

To test the third hypothesis of whether family firms mediate the corporate governance-earnings quality relationship, equation (4.4) which includes seven 
interaction variables of corporate governance measures and family influence is estimated. The variables are ACSIZE*FAMILY, ACIND*FAMILY, ACMEET*FAMILY, ACFIN*FAMILY, BODSIZE*FAMILY, BODIND*FAMILY and DUALITY*FAMILY. These variables measure the incremental effect of each corporate governance mechanism in the earnings quality relationship in family firms. If the coefficients of ACSIZE*FAMILY, ACIND*FAMILY, ACMEET*FAMILY, ACFIN*FAMILY, BODSIZE*FAMILY, BODIND*FAMILY and DUALITY*FAMILY are positive, family firms have significantly stronger ACSIZE-AQUALITY, ACINDAQUALITY, ACMEET-AQUALITY, ACFIN-AQUALITY, BODSIZE-AQUALITY, BODIND-AQUALITY and DUALITY-AQUALITY relationship than do nonfamily firms. Alternatively, a negative coefficient on the variables indicates a weaker corporate governance-earnings quality relationship in family firms.

Table 5.9 shows the regression estimates of equation (4.4) using again all four regression procedures. In the results from the basic regression, the coefficient for family firms (FAMILY) is positive and significant at 5\% level. This is consistent with the result reported in Table 5.6 that family firms have significantly higher earnings quality than nonfamily firms.

For audit committee size (ACSIZE), the coefficient is positive and significant but the coefficient on the interaction variable ACSIZE*FAMILY, is negative and significant. This result suggests that family influence weakens the impact of audit committee size on earnings quality. This is consistent with the results reported in Table 5.7 and 5.8, 
which suggests that audit committee size is only a determinant of earnings quality in nonfamily firms.

Similarly, for audit committee independence, the coefficient for ACIND is positive and significant but the interaction variable ACIND*FAMILY is negative and significant. This result is also consistent with the results reported in Table 5.7 and 5.8, which suggest that audit committee independence is only a determinant of earnings quality in nonfamily firms.

The negative and significant coefficient on the interaction variables ACSIZE*FAMILY and ACIND*FAMILY shows that the results support $\mathrm{H}_{3}$, that the relationship between earnings quality and corporate governance is weaker in family owned firms compared to nonfamily firms. 
Table 5.9: Regression Results of the Effect of Family Firms on the Relationship between Corporate Governance and Earnings Quality (Earnings Quality=AQUALITY)

\begin{tabular}{|c|c|c|c|c|c|c|c|c|}
\hline & \multicolumn{2}{|c|}{ Basic Regression } & \multicolumn{2}{|c|}{ White (1980) } & \multicolumn{2}{|c|}{$\begin{array}{c}\text { Industry \& } \\
\text { Year Effects }\end{array}$} & \multicolumn{2}{|c|}{$\begin{array}{c}\text { Fama \& MacBeth } \\
(1973)\end{array}$} \\
\hline & Coeff & $t$-stat & coeff & white- $t$ & coeff & $t$-stat & coeff & $t$-stat \\
\hline INTERCEPT & $-0.097 *$ & -3.985 & $-0.097 *$ & -3.615 & $-0.089 *$ & -3.368 & $-0.104 * * *$ & -2.272 \\
\hline FAMILY & $0.050 * *$ & 2.237 & $0.050 * *$ & 2.245 & $0.047 * *$ & 2.053 & $0.060 * * *$ & 2.068 \\
\hline ACSIZE & $0.007 *$ & 2.660 & $0.007 *$ & 2.687 & $0.006^{* *}$ & 2.306 & $0.007 * * *$ & 2.527 \\
\hline$A C I N D$ & $0.047 *$ & 3.456 & $0.047 *$ & 3.791 & $0.048 *$ & 3.445 & $0.042 *$ & 4.686 \\
\hline ACMEET & 0.000 & 0.018 & 0.000 & 0.014 & 0.000 & 0.216 & 0.001 & 0.254 \\
\hline$A C F I N$ & 0.001 & 0.087 & 0.001 & 0.077 & -0.000 & -0.052 & -0.001 & -0.167 \\
\hline BODSIZE & $-0.002 * *$ & -2.364 & $-0.002 * *$ & -2.030 & $-0.002 * *$ & -2.322 & $-0.003 * * *$ & -2.509 \\
\hline BODIND & -0.017 & -1.111 & -0.017 & -0.939 & -0.018 & -1.161 & -0.017 & -0.780 \\
\hline DUALITY & -0.004 & -0.810 & -0.004 & -0.688 & -0.003 & -0.697 & -0.003 & -0.828 \\
\hline ACSIZE*FAMILY & $-0.010 * *$ & -2.512 & $-0.010 *$ & -2.635 & $-0.009 * *$ & -2.407 & $-0.010 *$ & -4.601 \\
\hline$A C I N D * F A M I L Y$ & $-0.037 * * *$ & -1.920 & $-0.037 * *$ & -2.143 & $-0.036 * * *$ & -1.832 & $-0.049 * * *$ & -2.220 \\
\hline$A C M E E T^{*} F A M I L Y$ & 0.001 & 0.353 & 0.001 & 0.347 & 0.001 & 0.265 & -0.000 & -0.125 \\
\hline$A C F I N * F A M I L Y$ & -0.005 & -0.427 & -0.005 & -0.433 & -0.005 & -0.414 & -0.002 & -0.204 \\
\hline BODSIZE*FAMILY & 0.002 & 1.358 & 0.002 & 1.272 & 0.002 & 1.438 & 0.002 & 1.605 \\
\hline BODIND*FAMILY & 0.003 & 0.131 & 0.003 & 0.126 & 0.004 & 0.174 & 0.006 & 0.308 \\
\hline DUALITY*FAMILY & 0.006 & 0.980 & 0.006 & 0.950 & 0.006 & 0.983 & 0.005 & 0.960 \\
\hline BIG4 & -0.002 & -0.794 & -0.002 & -0.793 & -0.001 & -0.641 & -0.002 & -0.905 \\
\hline GROWTH & $-0.009 *$ & -6.040 & $-0.009 *$ & -4.945 & $-0.009 *$ & -5.641 & $-0.007 * *$ & -3.113 \\
\hline LEVERAGE & 0.000 & 0.056 & 0.000 & 0.050 & 0.003 & 0.325 & 0.003 & 0.302 \\
\hline SIZE & 0.003 & 1.082 & 0.003 & 1.027 & 0.002 & 0.793 & 0.004 & 0.871 \\
\hline$L O S S$ & $-0.014 *$ & -4.606 & $-0.014 *$ & -4.257 & $-0.013 *$ & -4.555 & $-0.014 *$ & -4.217 \\
\hline SALESVAR & $-0.021 *$ & -3.070 & $-0.021 *$ & -2.592 & $-0.023 *$ & -3.341 & $-0.021 * * *$ & -2.081 \\
\hline CAPINT & $0.028 *$ & 4.897 & $0.028 *$ & 4.748 & $0.026^{*}$ & 4.214 & $0.029 * *$ & 3.203 \\
\hline OPCYCLE & -0.003 & -1.336 & -0.003 & -1.287 & -0.003 & -1.063 & -0.003 & -1.587 \\
\hline CFOVAR & $-0.186^{*}$ & -7.259 & $-0.186 *$ & -5.685 & $-0.183^{*}$ & -7.110 & $-0.192 *$ & -6.799 \\
\hline INTINT & $-0.021 * *$ & -2.020 & -0.021 & -1.628 & $-0.024 * *$ & -2.285 & $-0.023 * *$ & -3.879 \\
\hline DISTRESS & -0.004 & -1.509 & -0.004 & -1.498 & -0.004 & -1.390 & -0.005 & -1.216 \\
\hline IND_l & & & & & 0.001 & 0.241 & & \\
\hline$I N D \_2$ & & & & & -0.005 & -0.973 & & \\
\hline IND_3 & & & & & 0.007 & 0.972 & & \\
\hline$I N D \_4$ & & & & & -0.004 & -0.665 & & \\
\hline$I N D \_5$ & & & & & -0.003 & -0.483 & & \\
\hline IND_6 & & & & & -0.005 & -1.005 & & \\
\hline$Y R \_2004$ & & & & & -0.003 & -0.723 & & \\
\hline$Y R \_2005$ & & & & & 0.005 & 1.401 & & \\
\hline$Y R \_2006$ & & & & & $0.008 * *$ & 1.993 & & \\
\hline$Y R \_2007$ & & & & & -0.002 & -0.423 & & \\
\hline$Y R \_2008$ & & & & & -0.000 & -0.058 & & \\
\hline $\operatorname{Adj} . R 2$ & 0.08 & & 0.08 & & 0.08 & & 0.12 & \\
\hline$O b s$ & 3162 & & 3162 & & 3162 & & 3162 & \\
\hline$F$-stat & 11.186 & & 7.986 & & 8.421 & & 25.318 & \\
\hline
\end{tabular}

Note: $*, * * * * *$ represents statistical significance at $0.01,0.05$ and 0.10 levels, respectively. All variables are as previously defined. 
For board size (BODSIZE), the coefficient is negative and significant but the interaction variables of board size and family (BODSIZE*FAMILY), although positive is not significant. This result is consistent with the result in Table 5.6, but the variable family influence does not appear to have a mediating effect on the board size-earnings quality relationship. For the other corporate governance variables, ACMEET, ACFIN, BODIND and DUALITY, and their interaction variables with FAMILY, the coefficients are not significant, consistent with the earlier result.

The results of estimation by the other three regression procedures are qualitatively similar. Overall, the result reported in Table 5.6 to 5.9 suggests that corporate governance in the form of audit committee size and independence and board size matter for nonfamily firms but not for family firms.

\subsection{Sensitivity Analyses}

This section provides the results for several sensitivity analyses using alternative measures for earnings quality and family influence. Specifically, Section 5.6.1 reports estimation results based on the original Dechow and Dichev (2002) model, as an alternative measure for earnings quality; and Section 5.6.2 presents the result of estimation using various alternative measures of family firms, including (i) family share ownership and (ii) family control of board. 


\subsubsection{Alternative Measure of Earnings Quality}

In this section, equations (4.3) to (4.6) are re-estimated using earnings quality estimate, $A Q 2$, which is derived from the absolute value of residuals from the original Dechow and Dichev (2002) model. The original model relates total current accrual (TCA), to lagged, current and future cash flows from operations based on the assumption that current accruals are estimates of future year's cash flow realisation. $A Q 2$ is the additive inverse of the absolute value of residuals from cross-sectional regressions of the model.

Table 5.10 presents the results from the estimation of equation (4.3) and (4.4), where the alternative measure for earnings quality (AQ2) is regressed on the measures for family firms (FAMILY), corporate governance and the control variables. Four estimations are repeated- the basic OLS regression, White's (1980) estimates, industry and year fixed effects regression, and Fama and MacBeth (1973) procedure.

Table 5.11 and 5.12 report the results of the similar regression for the nonfamily and family firm subsamples. Table 5.13 reports the results of the four regressions with interaction terms. In all cases, the results are qualitatively similar to those obtained with the variable AQUALITY. 
Table 5.10: Regression Results of Family Firms and Corporate Governance on Earnings Quality (Earnings Quality=AQ2)

\begin{tabular}{|c|c|c|c|c|c|c|c|c|}
\hline & \multicolumn{2}{|c|}{ Basic Regression } & \multicolumn{2}{|c|}{ White (1980) } & \multicolumn{2}{|c|}{$\begin{array}{c}\text { Industry \& } \\
\text { Year Effects }\end{array}$} & \multicolumn{2}{|c|}{$\begin{array}{c}\text { Fama \& MacBeth } \\
(1973)\end{array}$} \\
\hline & coeff & $t$-stat & coeff & white- $t$ & coeff & $t$-stat & coeff & $t$-stat \\
\hline INTERCEPT & $-0.098 *$ & -4.333 & $-0.098^{*}$ & -4.002 & $-0.086^{*}$ & -3.395 & $-0.102 * * *$ & -2.208 \\
\hline FAMILY & $0.007^{*}$ & 3.160 & $0.007^{*}$ & 3.131 & $0.007^{*}$ & 2.743 & $0.008 *$ & 4.711 \\
\hline ACSIZE & 0.003 & 1.600 & $0.003^{* * *} *$ & 1.661 & 0.003 & 1.251 & 0.003 & 1.720 \\
\hline$A C I N D$ & $0.030 *$ & 2.892 & $0.030 *$ & 3.214 & $0.030 *$ & 2.746 & 0.022 & 1.673 \\
\hline ACMEET & 0.001 & 1.010 & 0.001 & 0.955 & 0.001 & 1.174 & 0.001 & 0.794 \\
\hline$A C F I N$ & -0.005 & -0.778 & -0.005 & -0.791 & -0.006 & -0.915 & -0.006 & -1.010 \\
\hline BODSIZE & $-0.002 * *$ & -2.121 & $-0.002 * *$ & -2.046 & $-0.001 * * *$ & -1.914 & $-0.002 * *$ & -2.944 \\
\hline BODIND & -0.010 & -0.815 & -0.010 & -0.755 & -0.010 & -0.812 & -0.008 & -0.617 \\
\hline DUALITY & 0.000 & 0.143 & 0.000 & 0.146 & 0.001 & 0.377 & -0.000 & -0.021 \\
\hline BIG4 & -0.003 & -1.429 & -0.003 & -1.425 & -0.003 & -1.159 & $-0.003 * *$ & -3.070 \\
\hline GROWTH & $-0.011^{*}$ & -6.893 & $-0.011 *$ & -5.674 & $-0.010 *$ & -6.379 & $-0.009 * *$ & -3.907 \\
\hline LEVERAGE & $-0.015^{* * *}$ & -1.860 & -0.015 & -1.618 & -0.012 & -1.511 & -0.013 & -1.124 \\
\hline SIZE & $0.004 * * *$ & 1.813 & $0.004 * * *$ & 1.726 & 0.004 & 1.354 & 0.005 & 1.088 \\
\hline LOSS & $-0.017 *$ & -5.456 & $-0.017 *$ & -5.175 & $-0.017 *$ & -5.397 & $-0.017 *$ & -6.268 \\
\hline SALESVAR & $-0.029 *$ & -3.921 & $-0.029 *$ & -3.404 & $-0.030 *$ & -4.090 & $-0.029 * *$ & -2.855 \\
\hline CAPINT & $0.036 *$ & 5.892 & $0.036^{*}$ & 5.664 & $0.035^{*}$ & 5.344 & $0.037 *$ & 6.035 \\
\hline OPCYCLE & -0.003 & -1.162 & -0.003 & -1.086 & -0.003 & -0.981 & -0.003 & -0.988 \\
\hline CFOVAR & $-0.204 *$ & -7.569 & $-0.204 *$ & -5.879 & $-0.202 *$ & -7.450 & $-0.209 *$ & -7.067 \\
\hline INTINT & $-0.021 * *$ & -1.965 & -0.021 & -1.538 & $-0.025 * *$ & -2.285 & $-0.024 * *$ & -3.743 \\
\hline DISTRESS & -0.002 & -0.581 & -0.002 & -0.583 & -0.002 & -0.546 & -0.002 & -0.594 \\
\hline$I N D \_1$ & & & & & 0.000 & 0.039 & & \\
\hline$I N D \_2$ & & & & & $-0.009 * * *$ & -1.746 & & \\
\hline IND_3 & & & & & 0.001 & 0.185 & & \\
\hline IND_4 & & & & & -0.006 & -1.026 & & \\
\hline IND_5 & & & & & -0.007 & -1.003 & & \\
\hline IND_6 & & & & & -0.008 & -1.516 & & \\
\hline$Y R \_2004$ & & & & & -0.005 & -1.285 & & \\
\hline$Y R \_2005$ & & & & & 0.004 & 1.121 & & \\
\hline$Y R \_2006$ & & & & & 0.006 & 1.448 & & \\
\hline$Y R \_2007$ & & & & & -0.003 & -0.641 & & \\
\hline$Y R \_2008$ & & & & & 0.001 & 0.127 & & \\
\hline Adj.R2 & 0.09 & & 0.09 & & 0.10 & & 0.13 & \\
\hline Obs & 3162 & & 3162 & & 3162 & & 3162 & \\
\hline$F$-stat & 18.138 & & 12.878 & & 12.264 & & 44.730 & \\
\hline
\end{tabular}

Note: $*, * *, * * *$ represents statistical significance at $0.01,0.05$ and 0.10 levels, respectively. All variables are as previously defined 
Table 5.11: Regression Results of Corporate Governance on Earnings Quality in Nonfamily Firms (Earnings Quality $=A Q 2$ and $F A M I L Y=0$ )

\begin{tabular}{|c|c|c|c|c|c|c|c|c|}
\hline & \multicolumn{2}{|c|}{ Basic Regression } & \multicolumn{2}{|c|}{ White (1980) } & \multicolumn{2}{|c|}{$\begin{array}{c}\text { Industry \& } \\
\text { Year Effects }\end{array}$} & \multicolumn{2}{|c|}{$\begin{array}{c}\text { Fama \& MacBeth } \\
\text { (1973) }\end{array}$} \\
\hline & coeff & $t$-stat & coeff & white- $t$ & coeff & $t$-stat & coeff & $t$-stat \\
\hline INTERCEPT & $-0.142 *$ & -4.096 & $-0.142^{*}$ & -3.803 & $-0.123^{*}$ & -3.220 & $-0.145^{* * *}$ & -2.234 \\
\hline ACSIZE & $0.008^{*}$ & 2.722 & $0.008^{*}$ & 3.120 & $0.008 * *$ & 2.463 & $0.008 * * *$ & 2.478 \\
\hline$A C I N D$ & $0.046^{*}$ & 2.865 & $0.046^{*}$ & 3.387 & $0.047 *$ & 2.790 & $0.051 *$ & 10.289 \\
\hline ACMEET & 0.001 & 0.890 & 0.001 & 0.807 & 0.002 & 0.926 & 0.002 & 0.902 \\
\hline$A C F I N$ & -0.002 & -0.213 & -0.002 & -0.209 & -0.002 & -0.220 & -0.004 & -0.330 \\
\hline BODSIZE & $-0.002 * * *$ & -1.927 & $-0.002 * * *$ & -1.925 & $-0.002 * * *$ & -1.823 & $-0.003^{* * *}$ & -2.549 \\
\hline BODIND & -0.008 & -0.435 & -0.008 & -0.406 & -0.009 & -0.475 & -0.010 & -0.542 \\
\hline DUALITY & -0.003 & -0.611 & -0.003 & -0.597 & -0.003 & -0.577 & -0.003 & -0.707 \\
\hline$B I G 4$ & -0.004 & -1.006 & -0.004 & -1.017 & -0.004 & -0.975 & -0.003 & -1.167 \\
\hline GROWTH & $-0.014 *$ & -5.855 & $-0.014 *$ & -4.962 & $-0.013 *$ & -5.471 & $-0.011 * *$ & -2.927 \\
\hline LEVERAGE & -0.005 & -0.371 & -0.005 & -0.323 & -0.000 & -0.014 & -0.001 & -0.051 \\
\hline SIZE & $0.007 * * *$ & 1.940 & $0.007 * * *$ & 1.834 & 0.006 & 1.513 & 0.007 & 1.056 \\
\hline$L O S S$ & $-0.014 *$ & -2.961 & $-0.014 *$ & -2.867 & $-0.013^{*}$ & -2.864 & $-0.015^{*}$ & -4.084 \\
\hline SALESVAR & $-0.039 *$ & -3.709 & $-0.039 *$ & -3.315 & $-0.041 *$ & -3.857 & $-0.040 * *$ & -2.878 \\
\hline CAPINT & $0.030 *$ & 3.192 & $0.030 *$ & 3.067 & $0.030 *$ & 2.918 & $0.030 *$ & 4.452 \\
\hline OPCYCLE & -0.001 & -0.356 & -0.001 & -0.347 & -0.001 & -0.184 & -0.001 & -0.234 \\
\hline CFOVAR & $-0.159 *$ & -3.934 & $-0.159 *$ & -3.305 & $-0.155^{*}$ & -3.780 & $-0.167^{*}$ & -5.251 \\
\hline INTINT & -0.012 & -0.688 & -0.012 & -0.550 & -0.011 & -0.592 & -0.020 & -1.151 \\
\hline DISTRESS & $-0.010 * * *$ & -1.949 & $-0.010 * * *$ & -1.906 & $-0.010 * *$ & -2.022 & $-0.009 * *$ & -2.676 \\
\hline$I N D \_1$ & & & & & -0.009 & -0.912 & & \\
\hline$I N D \_2$ & & & & & -0.012 & -1.471 & & \\
\hline$I N D \_3$ & & & & & 0.002 & 0.134 & & \\
\hline$I N D \_4$ & & & & & -0.010 & -1.067 & & \\
\hline$I N D \_5$ & & & & & -0.013 & -1.211 & & \\
\hline IND_6 & & & & & -0.012 & -1.396 & & \\
\hline$Y R \_2004$ & & & & & -0.004 & -0.695 & & \\
\hline$Y R \_2005$ & & & & & 0.004 & 0.628 & & \\
\hline$Y R \_2006$ & & & & & 0.009 & 1.390 & & \\
\hline$Y R \_2007$ & & & & & -0.000 & -0.010 & & \\
\hline$Y R \_2008$ & & & & & -0.002 & -0.234 & & \\
\hline Adj.R2 & 0.09 & & 0.09 & & 0.09 & & 0.14 & \\
\hline Obs & 1542 & & 1542 & & 1542 & & 1542 & \\
\hline$F$-stat & 9.075 & & 7.433 & & 5.968 & & 113.244 & \\
\hline
\end{tabular}

Note: $* * *, * * *$ represents statistical significance at $0.01,0.05$ and 0.10 levels, respectively. All variables are as previously defined. 
Table 5.12: Regression results of corporate governance on earnings quality in family firms (Earnings Quality $=A Q 2$ and $F A M I L Y=1$ ).

\begin{tabular}{|c|c|c|c|c|c|c|c|c|}
\hline & \multicolumn{2}{|c|}{ Basic Regression } & \multicolumn{2}{|c|}{ White (1980) } & \multicolumn{2}{|c|}{$\begin{array}{c}\text { Industry \& } \\
\text { Year Effects }\end{array}$} & \multicolumn{2}{|c|}{$\begin{array}{c}\text { Fama \& MacBeth } \\
\text { (1973) }\end{array}$} \\
\hline & coeff & $t$-stat & coeff & white- $t$ & coeff & $t$-stat & coeff & $t$-stat \\
\hline INTERCEPT & -0.026 & -0.905 & -0.026 & -0.896 & -0.026 & -0.763 & -0.026 & -1.037 \\
\hline ACSIZE & -0.003 & -1.067 & -0.003 & -1.008 & -0.003 & -1.242 & -0.003 & -1.633 \\
\hline$A C I N D$ & 0.014 & 1.069 & 0.014 & 1.086 & 0.012 & 0.881 & -0.008 & -0.316 \\
\hline ACMEET & 0.001 & 0.436 & 0.001 & 0.491 & 0.001 & 0.445 & 0.000 & 0.188 \\
\hline$A C F I N$ & -0.009 & -1.075 & -0.009 & -1.186 & -0.010 & -1.182 & $-0.008 * *$ & -2.906 \\
\hline BODSIZE & -0.001 & -1.066 & -0.001 & -1.003 & -0.001 & -0.632 & -0.001 & -1.183 \\
\hline BODIND & -0.013 & -0.777 & -0.013 & -0.740 & -0.013 & -0.769 & -0.009 & -1.085 \\
\hline DUALITY & 0.004 & 1.035 & 0.004 & 1.136 & 0.005 & 1.219 & 0.004 & 1.364 \\
\hline$B I G 4$ & -0.003 & -0.929 & -0.003 & -0.929 & -0.002 & -0.620 & -0.003 & -1.201 \\
\hline GROWTH & $-0.007 *$ & -3.469 & $-0.007 *$ & -2.919 & $-0.006^{*}$ & -2.877 & $-0.006^{* * * *}$ & -2.231 \\
\hline LEVERAGE & $-0.023 * *$ & -2.367 & $-0.023 * *$ & -2.093 & $-0.024 * *$ & -2.341 & -0.022 & -1.489 \\
\hline$S I Z E$ & -0.000 & -0.053 & -0.000 & -0.053 & -0.000 & -0.059 & 0.001 & 0.311 \\
\hline LOSS & $-0.020 *$ & -4.947 & $-0.020 *$ & -4.737 & $-0.020 *$ & -4.725 & $-0.022 *$ & -5.437 \\
\hline SALESVAR & -0.012 & -1.170 & -0.012 & -1.087 & -0.014 & -1.300 & -0.014 & -1.568 \\
\hline CAPINT & $0.039 *$ & 4.901 & $0.039 *$ & 4.896 & $0.035^{*}$ & 4.170 & $0.040 *$ & 4.407 \\
\hline OPCYCLE & $-0.006^{* * *} *$ & -1.773 & -0.006 & -1.581 & $-0.006 * * *$ & -1.730 & $-0.006 * * *$ & -2.319 \\
\hline CFOVAR & $-0.241 *$ & -6.711 & $-0.241 *$ & -4.937 & $-0.236^{*}$ & -6.447 & $-0.235^{*}$ & -5.255 \\
\hline INTINT & $-0.026 * *$ & -2.053 & -0.026 & -1.526 & $-0.033 * *$ & -2.533 & -0.026 & -1.665 \\
\hline DISTRESS & 0.006 & 1.640 & $0.006 * * *$ & 1.711 & $0.008 * * *$ & 1.897 & 0.007 & 1.134 \\
\hline IND_l & & & & & 0.007 & 1.047 & & \\
\hline$I N D \_2$ & & & & & -0.005 & -0.770 & & \\
\hline IND_3 & & & & & 0.004 & 0.532 & & \\
\hline$I N D \_4$ & & & & & -0.002 & -0.310 & & \\
\hline IND_5 & & & & & -0.004 & -0.403 & & \\
\hline IND_6 & & & & & -0.003 & -0.448 & & \\
\hline$Y R \_2004$ & & & & & -0.006 & -1.157 & & \\
\hline$Y R \_2005$ & & & & & 0.005 & 1.109 & & \\
\hline$Y R \_2006$ & & & & & 0.004 & 0.733 & & \\
\hline$Y R \_2007$ & & & & & -0.005 & -1.048 & & \\
\hline$Y R \_2008$ & & & & & 0.004 & 0.662 & & \\
\hline Adj.R2 & 0.09 & & 0.09 & & 0.10 & & 0.16 & \\
\hline Obs & 1620 & & 1620 & & 1620 & & 1620 & \\
\hline$F$-stat & 9.954 & & 6.432 & & 6.884 & & 15.579 & \\
\hline
\end{tabular}

Note: $* * *, * * *$ represents statistical significance at $0.01,0.05$ and 0.10 levels, respectively. All variables are as previously defined. 
Table 5.13: Regression Results of the Effect of Family Firms on the Relationship between Corporate Governance and Earnings Quality (Earnings Quality=AQ2)

\begin{tabular}{|c|c|c|c|c|c|c|c|c|}
\hline & \multicolumn{2}{|c|}{ Basic Regression } & \multicolumn{2}{|c|}{ White (1980) } & \multicolumn{2}{|c|}{$\begin{array}{c}\text { Industry \& } \\
\text { Year Effects }\end{array}$} & \multicolumn{2}{|c|}{$\begin{array}{c}\text { Fama \& MacBeth } \\
\text { (1973) }\end{array}$} \\
\hline & coeff & $t$-stat & coeff & white- $t$ & coeff & $t$-stat & coeff & $t$-stat \\
\hline INTERCEPT & $-0.097 *$ & -3.985 & $-0.097 *$ & -3.615 & $-0.089 *$ & -3.368 & $-0.104 * * *$ & -2.272 \\
\hline FAMILY & $0.050 * *$ & 2.237 & $0.050 * *$ & 2.245 & $0.047 * *$ & 2.053 & $0.060 * * *$ & 2.068 \\
\hline$A C S I Z E$ & $0.007 *$ & 2.660 & $0.007 *$ & 2.687 & $0.006 * *$ & 2.306 & $0.007 * * *$ & 2.527 \\
\hline$A C I N D$ & $0.047 *$ & 3.456 & $0.047 *$ & 3.791 & $0.048^{*}$ & 3.445 & $0.042 *$ & 4.686 \\
\hline ACMEET & 0.000 & 0.018 & 0.000 & 0.014 & 0.000 & 0.216 & 0.001 & 0.25 \\
\hline$A C F I N$ & 0.001 & 0.087 & 0.001 & 0.077 & -0.000 & -0.052 & -0.001 & -0.167 \\
\hline BODSIZE & $-0.002 * *$ & -2.364 & $-0.002 * *$ & -2.030 & $-0.002 * *$ & -2.322 & $-0.003 * * *$ & -2.509 \\
\hline BODIND & -0.017 & -1.111 & -0.017 & -0.939 & -0.018 & -1.161 & -0.017 & -0.780 \\
\hline DUALITY & -0.004 & -0.810 & -0.004 & -0.688 & -0.003 & -0.697 & -0.003 & -0.828 \\
\hline ACSIZE*FAMILY & $-0.010 * *$ & -2.512 & $-0.010^{*}$ & -2.635 & $-0.009 * *$ & -2.407 & $-0.010^{*}$ & -4.601 \\
\hline$A C I N D * F A M I L Y$ & $-0.037 * * *$ & -1.920 & $-0.037 * *$ & -2.143 & $-0.036 * * *$ & -1.832 & $-0.049 * * *$ & -2.220 \\
\hline ACMEET*FAMILY & 0.001 & 0.353 & 0.001 & 0.347 & 0.001 & 0.265 & -0.000 & -0.125 \\
\hline$A C F I N * F A M I L Y$ & -0.005 & -0.427 & -0.005 & -0.433 & -0.005 & -0.414 & -0.002 & -0.204 \\
\hline BODSIZE*FAMILY & 0.002 & 1.358 & 0.002 & 1.272 & 0.002 & 1.438 & 0.002 & 1.605 \\
\hline BODIND*FAMILY & 0.003 & 0.131 & 0.003 & 0.126 & 0.004 & 0.174 & 0.006 & 0.308 \\
\hline$D U A L I T Y * F A M I L Y$ & 0.006 & 0.980 & 0.006 & 0.950 & 0.006 & 0.983 & 0.005 & 0.960 \\
\hline$B I G 4$ & -0.002 & -0.794 & -0.002 & -0.793 & -0.001 & -0.641 & -0.002 & -0.905 \\
\hline GROWTH & $-0.009 *$ & -6.040 & $-0.009 *$ & -4.945 & $-0.009 *$ & -5.641 & $-0.007 * *$ & -3.113 \\
\hline LEVERAGE & 0.000 & 0.056 & 0.000 & 0.050 & 0.003 & 0.325 & 0.003 & 0.302 \\
\hline SIZE & 0.003 & 1.082 & 0.003 & 1.027 & 0.002 & 0.793 & 0.004 & 0.871 \\
\hline LOSS & $-0.014 *$ & -4.606 & $-0.014^{*}$ & -4.257 & $-0.013^{*}$ & -4.555 & $-0.014^{*}$ & -4.217 \\
\hline SALESVAR & $-0.021 *$ & -3.070 & $-0.021 *$ & -2.592 & $-0.023^{*}$ & -3.341 & $-0.021 * * *$ & -2.081 \\
\hline CAPINT & $0.028 *$ & 4.897 & $0.028 *$ & 4.748 & $0.026 *$ & 4.214 & $0.029 * *$ & 3.203 \\
\hline OPCYCLE & -0.003 & -1.336 & -0.003 & -1.287 & -0.003 & -1.063 & -0.003 & -1.587 \\
\hline CFOVAR & $-0.186^{*}$ & -7.259 & $-0.186^{*}$ & -5.685 & $-0.183^{*}$ & -7.110 & $-0.192^{*}$ & -6.799 \\
\hline INTINT & $-0.021 * *$ & -2.020 & -0.021 & -1.628 & $-0.024 * *$ & -2.285 & $-0.023 * *$ & -3.879 \\
\hline DISTRESS & -0.004 & -1.509 & -0.004 & -1.498 & -0.004 & -1.390 & -0.005 & -1.216 \\
\hline IND_I & & & & & 0.001 & 0.241 & & \\
\hline IND_2 & & & & & -0.005 & -0.973 & & \\
\hline$I N D \_3$ & & & & & 0.007 & 0.972 & & \\
\hline$I N D \_4$ & & & & & -0.004 & -0.665 & & \\
\hline$I N D \_5$ & & & & & -0.003 & -0.483 & & \\
\hline IND_6 & & & & & -0.005 & -1.005 & & \\
\hline$Y R \_2004$ & & & & & -0.003 & -0.723 & & \\
\hline$Y R \_2005$ & & & & & 0.005 & 1.401 & & \\
\hline$Y R \_2006$ & & & & & $0.008 * *$ & 1.993 & & \\
\hline$Y R \_2007$ & & & & & -0.002 & -0.423 & & \\
\hline$Y R \_2008$ & & & & & -0.000 & -0.058 & & \\
\hline Adj.R2 & 0.08 & & 0.08 & & 0.08 & & 0.12 & \\
\hline Obs & 3162 & & 3162 & & 3162 & & 3162 & \\
\hline$F$-stat & 11.186 & & 7.986 & & 8.421 & & 25.318 & \\
\hline
\end{tabular}

Note: $* * *, * * *$ represents statistical significance at $0.01,0.05$ and 0.10 levels, respectively. All variables are as previously defined. 


\subsubsection{Alternative Measures of Family Influence}

This section presents the results of regression estimates of equation (4.3) to (4.6) using alternative definitions for family firms. In Section 5.6.2.1, family firms are identified based on the percentage of family members' equity holdings. Based on this definition, all firms with family ownership more than $20 \%$ of total firms equity are considered as family firms. In Section 5.6.2.2, family firms are identified based on family control of board of directors, regardless of their shareholdings. Firms are classified as family firms if two or more family members are appointed as directors. In Section 5.6.2.3, additional analysis of firms with family ownership is presented. These firms are examined based on family ethnicity, to provide further understanding of the corporate governance-earnings quality relationship in family firms in Malaysia.

\subsubsection{Measuring Family Influence Based on Family Share Ownership}

In this section, family firms are identified based on the percentage of shares owned by

the controlling family. Based on this measure, family firms, FAM2O, is coded one if family members own more than $20 \%$ firm shares, and coded zero otherwise. The estimation results for equation (4.4) and (4.6) using FAM20 are presented in Table 5.14 . 
Table 5.14: Regression Results of the Effect of Family Share Ownership on the Relationship between Corporate Governance and Earnings Quality (Earnings Quality=AQUALITY)

\begin{tabular}{|c|c|c|c|c|c|c|c|c|}
\hline & \multicolumn{2}{|c|}{ Basic Regression } & \multicolumn{2}{|c|}{ White (1980) } & \multicolumn{2}{|c|}{$\begin{array}{c}\text { Industry \& } \\
\text { Year Effects }\end{array}$} & \multicolumn{2}{|c|}{$\begin{array}{c}\text { Fama \& MacBeth } \\
(1973)\end{array}$} \\
\hline & coeff & $t$-stat & coeff & white- $t$ & coeff & $t$-stat & coeff & $t$-stat \\
\hline INTERCEPT & $-0.121 *$ & -4.159 & $-0.121 *$ & -3.625 & $-0.116^{*}$ & -3.686 & $-0.131 * * *$ & -2.481 \\
\hline FAM20 & $0.073^{*}$ & 2.848 & $0.073^{*}$ & 2.613 & $0.070 *$ & 2.729 & $0.083^{* *}$ & 2.735 \\
\hline$A C S I Z E$ & $0.007 * *$ & 1.987 & $0.007 * *$ & 2.091 & $0.007 * * *$ & 1.732 & 0.007 & 1.778 \\
\hline$A C I N D$ & $0.046 * *$ & 2.482 & $0.046^{*}$ & 2.659 & $0.047 * *$ & 2.457 & $0.052 *$ & 4.229 \\
\hline ACMEET & -0.000 & -0.009 & -0.000 & -0.006 & 0.001 & 0.263 & 0.002 & 0.335 \\
\hline$A C F I N$ & -0.013 & -0.978 & -0.013 & -0.876 & -0.014 & -1.054 & $-0.015 * * *$ & -2.092 \\
\hline BODSIZE & -0.000 & -0.193 & -0.000 & -0.174 & -0.000 & -0.198 & -0.001 & -0.407 \\
\hline BODIND & 0.016 & 0.727 & 0.016 & 0.662 & 0.014 & 0.632 & 0.011 & 0.430 \\
\hline DUALITY & -0.001 & -0.221 & -0.001 & -0.199 & -0.001 & -0.159 & -0.002 & -0.616 \\
\hline ACSIZE*FAM20 & -0.007 & -1.628 & $-0.007 * * *$ & -1.707 & -0.007 & -1.564 & $-0.006^{* * *}$ & -2.124 \\
\hline$A C I N D * F A M 20$ & -0.024 & -1.115 & -0.024 & -1.212 & -0.023 & -1.034 & $-0.044 * * *$ & -2.101 \\
\hline$A C M E E T^{*} F A M 20$ & 0.000 & 0.071 & 0.000 & 0.053 & -0.000 & -0.116 & -0.001 & -0.289 \\
\hline$A C F I N * F A M 20$ & 0.013 & 0.858 & 0.013 & 0.797 & 0.013 & 0.847 & 0.015 & 1.488 \\
\hline BODSIZE*FAM20 & -0.002 & -0.900 & -0.002 & -0.815 & -0.001 & -0.809 & -0.001 & -0.487 \\
\hline BODIND*FAM2O & $-0.046^{* * *} *$ & -1.801 & $-0.046^{* * *}$ & -1.663 & $-0.043 * * *$ & -1.677 & -0.041 & -1.891 \\
\hline$D U A L I T Y * F A M 20$ & 0.001 & 0.102 & 0.001 & 0.094 & 0.001 & 0.131 & 0.002 & 0.342 \\
\hline BIG4 & -0.002 & -0.859 & -0.002 & -0.865 & -0.002 & -0.714 & -0.001 & -0.910 \\
\hline GROWTH & $-0.009 *$ & -5.862 & $-0.009 *$ & -4.797 & $-0.008 *$ & -5.392 & $-0.007 * *$ & -2.899 \\
\hline LEVERAGE & 0.002 & 0.294 & 0.002 & 0.261 & 0.004 & 0.541 & 0.005 & 0.524 \\
\hline SIZE & 0.002 & 0.949 & 0.002 & 0.901 & 0.002 & 0.747 & 0.003 & 0.723 \\
\hline LOSS & $-0.014 *$ & -4.640 & $-0.014 *$ & -4.296 & $-0.013 *$ & -4.570 & $-0.014^{*}$ & -4.217 \\
\hline SALESVAR & $-0.023^{*}$ & -3.380 & $-0.023 *$ & -2.843 & $-0.025^{*}$ & -3.592 & $-0.023 * * *$ & -2.210 \\
\hline CAPINT & $0.030 *$ & 5.174 & $0.030 *$ & 4.993 & $0.028 *$ & 4.459 & $0.031 * *$ & 3.372 \\
\hline OPCYCLE & -0.003 & -1.256 & -0.003 & -1.215 & -0.003 & -0.991 & -0.003 & -1.457 \\
\hline CFOVAR & $-0.189 *$ & -7.380 & $-0.189 *$ & -5.812 & $-0.186^{*}$ & -7.212 & $-0.194 *$ & -6.999 \\
\hline INTINT & $-0.022 * *$ & -2.154 & $-0.022 * * *$ & -1.728 & $-0.026^{* *}$ & -2.502 & $-0.025 * *$ & -3.797 \\
\hline DISTRESS & $-0.005 * * *$ & -1.741 & $-0.005 * * *$ & -1.724 & -0.005 & -1.568 & -0.006 & -1.394 \\
\hline$I N D \_1$ & & & & & 0.002 & 0.423 & & \\
\hline IND_2 & & & & & -0.005 & -0.947 & & \\
\hline$I N D \_3$ & & & & & 0.006 & 0.929 & & \\
\hline IND_4 & & & & & -0.003 & -0.631 & & \\
\hline$I N D \_5$ & & & & & -0.003 & -0.385 & & \\
\hline IND_6 & & & & & -0.006 & -1.165 & & \\
\hline$Y R \_2004$ & & & & & -0.002 & -0.657 & & \\
\hline$Y R \_2005$ & & & & & 0.006 & 1.473 & & \\
\hline$Y R \_2006$ & & & & & $0.008 * *$ & 2.099 & & \\
\hline$Y R \_2007$ & & & & & -0.001 & -0.294 & & \\
\hline$Y R \_2008$ & & & & & 0.000 & 0.062 & & \\
\hline $\operatorname{Adj.R2}$ & 0.08 & & 0.08 & & 0.08 & & 0.12 & \\
\hline Obs & 3162 & & 3162 & & 3162 & & 3162 & \\
\hline$F$-stat & 11.041 & & 7.701 & & 8.367 & & 86.558 & \\
\hline
\end{tabular}

Note: $*, * * * * *$ represents statistical significance at $0.01,0.05$ and 0.10 levels, respectively. All variables are as previously defined. 
Based on the results from the basic OLS regression of equation (4.4), the coefficient FAM20, like that on FAMILY, is positive and significant and the coefficients for ACSIZE and ACIND are both positive and significant. However, while the coefficients of interaction variable $B O D I N D * F A M 2 O$ is negative and marginally significant, coefficients of $A C S I Z E^{*} F A M 20$ and $A C I N D^{*} F A M 20$ are negative but not significant. Furthermore, the coefficient on BODSIZE is also negative but not significant.

The results for FAM20, ACSIZE, ACIND, BODSIZE and BODIND*FAM20 are qualitatively similar for the three other regression procedures except that the coefficients on the interaction on the variable ACSIZE*FAM2O are negative and significant using White (1980 and Fama-MacBeth (1973) procedures, and the coefficient on the interaction on the variable ACIND*FAM20 and ACFIN are negative and significant using Fama-MacBeth (1973) procedure. Thus, the results are not the same as those obtained with the variable FAMILY but nevertheless they are similar.

\subsubsection{Measuring Family Influence Based on Family Control of Board}

In this section, family firms are identified based solely on the presence of family control over the board of directors. In this measure, family firms, FAMBOD, is coded one if two or more family members are directors, and coded zero otherwise. Table 5.15 present the estimation result for equation (4.4) and (4.6) using FAMBOD. 
Table 5.15: Regression Results of the Effect of Family Control on the Relationship between Corporate Governance and Earnings Quality (Earnings Quality=AQUALITY)

\begin{tabular}{|c|c|c|c|c|c|c|c|c|}
\hline & \multicolumn{2}{|c|}{ Basic Regression } & \multicolumn{2}{|c|}{ White (1980) } & \multicolumn{2}{|c|}{$\begin{array}{l}\text { Industry \& } \\
\text { Year Effects }\end{array}$} & \multicolumn{2}{|c|}{$\begin{array}{l}\text { Fama \& MacBeth } \\
\text { (1973) }\end{array}$} \\
\hline & coeff & $t$-stat & coeff & white- $t$ & coeff & $t$-stat & coeff & $t$-stat \\
\hline INTERCEPT & $-0.094 *$ & -3.757 & $-0.094 *$ & -3.385 & $-0.086^{*}$ & -3.173 & $-0.099 * * *$ & -2.053 \\
\hline FAMBOD & $0.039 * * *$ & 1.709 & $0.039 * * *$ & 1.670 & 0.035 & 1.529 & 0.045 & 1.658 \\
\hline$A C S I Z E$ & $0.007 * *$ & 2.491 & $0.007 * *$ & 2.486 & $0.006 * *$ & 2.127 & $0.007 * *$ & 2.948 \\
\hline$A C I N D$ & $0.047 *$ & 3.287 & $0.047 *$ & 3.522 & $0.048 *$ & 3.284 & $0.040 * *$ & 3.872 \\
\hline ACMEET & 0.000 & 0.308 & 0.000 & 0.233 & 0.001 & 0.511 & 0.001 & 0.428 \\
\hline$A C F I N$ & -0.000 & -0.048 & -0.000 & -0.043 & -0.002 & -0.245 & -0.002 & -0.190 \\
\hline BODSIZE & $-0.003^{*}$ & -2.837 & $-0.003 * *$ & -2.392 & $-0.003 *$ & -2.780 & $-0.003 * *$ & -3.571 \\
\hline BODIND & -0.017 & -1.023 & -0.017 & -0.854 & -0.018 & -1.092 & -0.017 & -0.731 \\
\hline DUALITY & -0.005 & -1.029 & -0.005 & -0.851 & -0.005 & -0.973 & -0.004 & -0.903 \\
\hline$A C S I Z E^{*} F A M B O D$ & $-0.008 * *$ & -2.139 & $-0.008 * *$ & -2.219 & $-0.008 * *$ & -2.023 & $-0.008^{*}$ & -5.157 \\
\hline$A C I N D * F A M B O D$ & $-0.033 * * *$ & -1.670 & $-0.033 * * *$ & -1.844 & -0.031 & -1.591 & $-0.038 * * *$ & -2.209 \\
\hline$A C M E E T^{*} F A M B O D$ & -0.000 & -0.007 & -0.000 & -0.006 & -0.000 & -0.120 & -0.001 & -0.458 \\
\hline$A C F I N * F A M B O D$ & -0.004 & -0.297 & -0.004 & -0.295 & -0.003 & -0.203 & -0.002 & -0.158 \\
\hline$B O D S I Z E^{*} F A M B O D$ & $0.003 * *$ & 1.996 & $0.003 * * *$ & 1.824 & $0.003 * *$ & 2.049 & $0.003 * *$ & 2.877 \\
\hline$B O D I N D * F A M B O D$ & 0.002 & 0.068 & 0.002 & 0.063 & 0.003 & 0.118 & 0.005 & 0.326 \\
\hline$D U A L I T Y^{*} F A M B O D$ & 0.008 & 1.239 & 0.008 & 1.154 & 0.008 & 1.303 & 0.006 & 1.049 \\
\hline BIG4 & -0.002 & -0.753 & -0.002 & -0.753 & -0.001 & -0.608 & -0.002 & -0.948 \\
\hline GROWTH & $-0.009 *$ & -5.933 & $-0.009 *$ & -4.876 & $-0.009 *$ & -5.571 & $-0.007 * *$ & -3.049 \\
\hline LEVERAGE & -0.000 & -0.017 & -0.000 & -0.015 & 0.002 & 0.243 & 0.002 & 0.232 \\
\hline SIZE & 0.003 & 1.088 & 0.003 & 1.032 & 0.002 & 0.810 & 0.004 & 0.847 \\
\hline LOSS & $-0.014^{*}$ & -4.669 & $-0.014 *$ & -4.292 & $-0.014 *$ & -4.608 & $-0.014 *$ & -4.062 \\
\hline SALESVAR & $-0.022 *$ & -3.124 & $-0.022 *$ & -2.643 & $-0.024 *$ & -3.399 & $-0.021 * * *$ & -2.144 \\
\hline CAPINT & $0.028^{*}$ & 4.874 & $0.028 *$ & 4.733 & $0.026 *$ & 4.159 & $0.028 * *$ & 3.237 \\
\hline OPCYCLE & -0.004 & -1.403 & -0.004 & -1.347 & -0.003 & -1.097 & -0.004 & -1.533 \\
\hline CFOVAR & $-0.187^{*}$ & -7.309 & $-0.187 *$ & -5.732 & $-0.184 *$ & -7.146 & $-0.194 *$ & -7.093 \\
\hline INTINT & $-0.020 * * *$ & -1.896 & -0.020 & -1.537 & $-0.023 * *$ & -2.171 & $-0.022 * *$ & -3.658 \\
\hline DISTRESS & -0.004 & -1.425 & -0.004 & -1.414 & -0.004 & -1.284 & -0.005 & -1.233 \\
\hline$I N D \_1$ & & & & & 0.002 & 0.330 & & \\
\hline$I N D \_2$ & & & & & -0.005 & -0.934 & & \\
\hline IND_3 & & & & & 0.007 & 1.052 & & \\
\hline$I N D \_4$ & & & & & -0.004 & -0.682 & & \\
\hline IND_5 & & & & & -0.003 & -0.515 & & \\
\hline IND_6 & & & & & -0.005 & -0.916 & & \\
\hline$Y R \_2004$ & & & & & -0.003 & -0.731 & & \\
\hline$Y R \_2005$ & & & & & 0.005 & 1.395 & & \\
\hline$Y R \_2006$ & & & & & $0.007 * * *$ & 1.960 & & \\
\hline$Y R \_2007$ & & & & & -0.002 & -0.441 & & \\
\hline$Y R \_2008$ & & & & & -0.000 & -0.104 & & \\
\hline Adj.R2 & 0.08 & & 0.08 & & 0.08 & & 0.12 & \\
\hline Obs & 3162 & & 3162 & & 3162 & & 3162 & \\
\hline$F$-stat & 11.182 & & 8.049 & & 8.430 & & 25.867 & \\
\hline
\end{tabular}

Note: $*, * *, * * *$ represents statistical significance at $0.01,0.05$ and 0.10 levels, respectively. All variables are as previously defined. 
The results of the basic OLS regression with FAMBOD are very similar to those obtained with FAMILY, as reported in Table 5.9 except that the coefficient in the interaction variable $B O D S I Z E^{*} F A M B O D$ is not only positive but also significant thus indicating that family influence also mitigates the effect of board size. The results for the other three regressions procedures are qualitatively the same. Thus, overall the results are very similar to those obtained with the variable FAMILY.

\subsubsection{Additional Analysis: Corporate Governance-Earnings Quality Relationship in Chinese and Malay Family Firms}

As mentioned in Chapter 2, due to the New Economic Policy of 1969, the majority of Malaysian business are controlled by two major ethnicities, the Malay (Bumiputera) and Chinese. Haniffa and Cooke (2002) found that in Malaysia, Chinese families are more secretive in their financial reporting. According to Zapalska and Edwards (2001), Chinese family culture is mostly influenced by Confucianism that promotes strong paternalism and collectivism within the families. Chinese culture demands a very strong commitment to families (Zapalska and Edwards, 2001). Therefore, as business is regarded as an extension of the family system, Chinese business owners are more dedicated and more aggressively involved in their business.

On the other hand, firms owned by Malay families are perceived to be more politically connected and have closer relationship with the government. Haniffa and Cooke (2005) document that Malay firms are positively related to voluntary disclosure and corporate social disclosure. They explain that Malay firms adopt a 
reactive legitimating strategy by increasing the social responsibility disclosures to divert the attention of their stakeholders away from the close relationship they have with government. Due to high level of voluntary disclosure of Malay firms documented by Haniffa and Cooke (2005), Rahman and Ali (2006) posit that Malay firms may have fewer tendencies to manage earnings. The differences in the cultural values of Malay and Chinese families may thus lead to differences in the corporate governance- earnings quality relationship of the two groups of family firms.

To test for this difference, the sample of family owned firms is partitioned into subsamples of Malay and Chinese firms. A firm is considered to be a Chinese family firm if it has more than $20 \%$ family shares and the majority of board is Chinese. Similarly, a firm is categorised as a Malay family firm if it has more than $20 \%$ family shares and the majority of the board is Malay. Equation (4.5) is estimated for both subsamples and the results are reported in Table 5.16.

Table 5.16 illustrates that from 2358 firm-year observation of family owned firms, only 686 firm-year observations are from Malay family firms, while the remaining 1672 are from Chinese family firms. This shows that within the firms that have more than $20 \%$ family ownership in the study, more than $70 \%$ are of Chinese families. 
Table 5.16: Regression Results of Corporate Governance on Earnings Quality in Chinese and Malay Family Owned Firms (Earnings Quality=AQUALITY)

\begin{tabular}{|c|c|c|c|c|}
\hline & \multicolumn{2}{|c|}{ Malay Family Firms } & \multicolumn{2}{|c|}{ Chinese Family Firms } \\
\hline & coeff & $t$-stat & coeff & $t$-stat \\
\hline INTERCEPT & 0.008 & 0.137 & -0.042 & -1.377 \\
\hline ACSIZE & 0.005 & 1.148 & -0.003 & -0.975 \\
\hline$A C I N D$ & 0.041 & 1.623 & 0.014 & 1.087 \\
\hline ACMEET & -0.001 & -0.441 & 0.001 & 0.864 \\
\hline ACFIN & 0.009 & 0.617 & -0.004 & -0.493 \\
\hline BODSIZE & $-0.003 * *$ & -2.048 & -0.001 & -0.671 \\
\hline BODIND & $-0.048 * * *$ & -1.735 & -0.024 & -1.544 \\
\hline DUALITY & 0.001 & 0.095 & 0.001 & 0.355 \\
\hline BIG4 & -0.000 & -0.003 & -0.003 & -0.918 \\
\hline GROWTH & -0.005 & -1.580 & $-0.008^{*}$ & -3.661 \\
\hline LEVERAGE & $0.038^{* * *}$ & 1.931 & -0.009 & -0.933 \\
\hline SIZE & -0.004 & -0.693 & 0.000 & 0.130 \\
\hline LOSS & -0.010 & -1.501 & $-0.015^{*}$ & -4.051 \\
\hline SALESVAR & -0.026 & -1.611 & $-0.021^{* *}$ & -2.307 \\
\hline CAPINT & 0.020 & 1.283 & $0.034 *$ & 4.382 \\
\hline OPCYCLE & -0.001 & -0.147 & -0.005 & -1.451 \\
\hline CFOVAR & $-0.241^{*}$ & -4.683 & $-0.161^{*}$ & -4.095 \\
\hline INTINT & -0.029 & -1.220 & $-0.037 *$ & -2.831 \\
\hline DISTRESS & -0.010 & -1.440 & 0.002 & 0.486 \\
\hline$I N D \_1$ & -0.010 & -0.778 & 0.009 & 1.422 \\
\hline$I N D \_2$ & $-0.027^{* *}$ & -2.530 & 0.005 & 0.758 \\
\hline$I N D \_3$ & -0.016 & -0.926 & $0.017^{* *}$ & 2.054 \\
\hline$I N D \_4$ & -0.016 & -1.198 & 0.001 & 0.165 \\
\hline$I N D \_5$ & -0.009 & -0.605 & -0.003 & -0.327 \\
\hline IND_6 & $-0.022^{* *}$ & -2.165 & 0.007 & 1.046 \\
\hline$Y R_{-} 2004$ & 0.001 & 0.144 & -0.005 & -1.156 \\
\hline$Y R \_2005$ & 0.002 & 0.261 & 0.006 & 1.362 \\
\hline$Y R \_2006$ & 0.014 & 1.602 & 0.002 & 0.371 \\
\hline$Y R \_2007$ & -0.003 & -0.355 & -0.000 & -0.088 \\
\hline$Y R \_2008$ & 0.007 & 0.742 & 0.002 & 0.307 \\
\hline$\overline{A d j . R 2}$ & 0.06 & & 0.07 & \\
\hline$O b s$ & 686 & & 1672 & \\
\hline F-stat & 2.630 & & 5.283 & \\
\hline
\end{tabular}

Note: *,**,*** represents statistical significance at $0.01,0.05$ and 0.10 levels, respectively. Firms are considered as Chinese family is when it has more than $20 \%$ family shares and majority of board is dominated by Chinese directors. Malay family firms are firms that have more than $20 \%$ family shares and with a majority of Malay directors in board. All variables are as previously defined.

For Malay family firms, corporate governance variables show a significant association with earnings quality. Specifically, the coefficients for board size $(B O D S I Z E)$ and board independence (BODIND) are negatively significant at $5 \%$ 
level and $10 \%$ level, respectively. This indicates that in Malay family firms, bigger and more independent board are associated with lower quality of earnings. The finding on board size supports the argument that a smaller board is more effective in monitoring management. However, the result on board independence is contrary to the argument that a more independent board of directors would results in better monitoring and thus higher quality of financial reporting. The result could be due to the possibility that in family firms, lower board independence reflects higher involvement of family members in board, and thus greater monitoring by family members.

For Chinese family firms, no corporate governance variables are significantly associated with earnings quality. This result supports view that in family firms, corporate governance mechanisms do not add to the monitoring provided by the family.

\subsection{Discussion and Conclusions}

This study had three main objectives. The study aimed (1) to examine the association between earnings quality and corporate governance, (2) to examine the relationship between earnings quality and family influence, and (3) to examine whether the influence of family firms mitigates the relationship between corporate governance and earnings quality. The results show that in general, audit committee independence and board size are significantly associated with earnings quality. The results also show that the quality of earnings is higher in family firms relative to nonfamily firms. 
However, the significance of corporate governance variables is due to the nonfamily firms in the sample as none of the corporate governance variables has significant association with earnings quality in family firms. The following subsections provide further discussions on the results.

\subsubsection{Earnings Quality and Family Firms}

Consistent with the argument that family firms are more likely to report higher quality of earnings, this study finds a significant positive association between family firms $(F A M I L Y)$ and quality of reported earnings. In particular, this finding is robust across different measures of earnings quality (AQUALITY and AQ2) and different measures of family firms (FAMILY, FAM2O and FAMBOD). The evidence suggest that a significant amount of family ownership, coupled with the presence of family members on the board reduces agency costs, resulting in better quality of earnings. Overall, the results of the study reject the first null hypothesis, $\left(\mathrm{H}_{01}\right)$, that there is a no difference between the earnings quality of family and nonfamily firms. The findings of this study thus support the alignment hypothesis and Fama and Jensen's (1983b) suggestion that family influence, through ownership and control provide better monitoring.

The evidence that family influence results in better monitoring of firms management is consistent with Wang (2006) who reports higher quality of earnings in firms owned by founding families in the United States. Similarly, Ali et al. (2007) show that compared to their nonfamily counterparts, family firms in the United States are less 
likely to manipulate discretionary accruals and are more likely to warn of bad news. A study in China by Yang (2010) also suggests that the appointment of family members as the CEO in family firms improves earnings quality. Yang documents (2010) that the family CEO has a lower tendency to manage earnings relative to a nonfamily CEO, supporting the alignment of interests between family and minority shareholders. Consistently, Sánchez et al. (2007) also provides evidence that earnings quality is higher in family firms relative to non-family firms in Spain. Sánchez et al. (2007) suggest that family firms have lower discretionary accruals and greater predictability of future cash flows due to their long-term orientation.

The result is also consistent with other related studies, which examine the association between family ownership and firm performance (e.g. Anderson and Reeb, 2003a; Chu and Cheah, 2006; McConaughy et al., 2001). Using a sample of companies from the United States, Anderson and Reeb (2003a) report that family firms are better than nonfamily firms in terms of performance and suggest that family ownership is an effective organisational structure. Their study concludes that in well-regulated and transparent markets, family ownership in public firms reduces agency problems without leading to severe losses in decision-making efficiency. Similarly, McConaughy et al. (2001) show that founding family controlled firms operate more efficiently, carry less debt than other firms and have greater market value as a result of combined high performance and low risk. The study also finds that greater alignment of managerial and shareholders' interests through managerial ownership only occur in family firms. In Malaysia, Chu and Cheah (2006) also reported a 
positive and significant relationship between family ownership and performance. The study suggests that in principle, family controlled firms still maintain the passion of entrepreneurship, which focuses on firm output efficiency- expansion as well as on maximisation of shareholders' value.

The result of the current study supports the notion that family firms have special qualities that allow them to effectively monitor the firm's activities. Higher quality of earnings in family firms could be a result of family firm's altruism and long-term orientation that reduce the incentives for earnings manipulations. Additionally, the results could also be due to the fact that family firms have lower agency costs and greater expertise relating to firm's operation that provides them with additional advantage in performing the monitoring function.

\subsubsection{Earnings Quality and Corporate Governance}

\subsubsection{Audit Committee Size}

Consistent with evidence from the previous studies (e.g. Lin et al., 2006; Yang and Krishnan, 2005), this study supports the argument that a larger audit committee would provide better governance and thus ensure higher quality of financial statements. However, this study does not find a significant association between audit committee size (ACSIZE) and earnings quality for the full sample of Malaysian firms. Further analysis reveals that while this result holds for family firms, for nonfamily firms this corporate governance variable is significant. In respect of nonfamily firms, consistent with the United States study by Yang and Krishnan (2005) and Lin et al. 
(2006), this study finds the evidence that a larger audit committee is associated with better quality of reported earnings.

\subsubsection{Audit Committee Independence}

The study also finds that there is a significant positive association between audit committee independence $(A C I N D)$ and the quality of reported earnings. However, as with audit committee size, this association holds only for non-family firms. The results are also robust in nearly all sensitivity analyses.

The result of this study for nonfamily firms is consistent with empirical evidence from prior studies, which suggest that higher levels of audit committee independence, improves monitoring and results in higher quality of financial reporting. For example, prior studies reported that companies with more independent audit committee are less likely to have financial restatements (Abbott et al., 2004), less likely to commit financial reporting fraud (Beasley et al., 2000), and more likely to have lower earnings management (Bédard et al., 2004; Klein, 2002). Consistently, Bradbury et al.'s (2006) study in Malaysia and Singapore also found a significant reduction in the level of income-increasing accruals in companies with fully independent audit committee members and Saleh et al. (2007) show that the presence of a fully independent audit committee reduces earnings management practices of Malaysian firms. 
This finding suggests that a more independent audit committee is more effective in performing its oversight role and ensuring high quality of financial reporting. This is because independent audit committee members provide more objective monitoring of company's financial reporting relative to other members as they do not have personal interests in the company. Moreover, the independent members are committed in performing their monitoring role in order to preserve and develop their reputation. Relative to other audit committee members, independent members also have greater incentive to avoid activities that could damage their reputation (Abbott and Parker, 2000; Abbott et al., 2003b).

\subsubsection{Audit Committee Meeting Frequency}

Despite the argument that more frequent audit committee meetings promotes greater diligence and effectiveness of audit committee in monitoring firm's financial reporting, this study did not find any association between audit committee meeting frequency (ACMEET) and earnings quality. The result, which is consistent in all regressions and sensitivity analyses, leads to the conclusion that there is no basis to reject the null hypothesis that there is no association between the frequency of audit committee meetings and earnings quality.

This result of the study is consistent with the Bédard et al. (2004) study in the United States, which also found that the frequency of audit committee meetings does not seems to affect the probability of aggressive earnings management. Similarly, Rahman and Ali (2006) do not find evidence to support a relationship between the 
frequency of audit committee meetings and firm's level of earnings management in Malaysia.

This finding suggests that looking only at the frequency of meetings of an audit committee is not sufficient to assess the effectiveness of the committee. Other factors such as the amount of information exchanged between the members, the depth of discussion on financial reporting matters, the content and length of the meetings and the post-meeting actions relating to the issues discussed in the meetings could be helpful in assessing the effectiveness of an audit committee.

\subsubsection{Audit Committee Financial Expertise}

Similar to a number of prior studies (Anderson et al., 2004; Carcello and Neal, 2003; DeFond, Hann, and Hu, 2005; Lee, Mande, and Ortman, 2004; Saleh et al., 2007), this study fails to provide evidence that financial expertise of audit committee members could positively influence audit committee effectiveness. From the regression results, the coefficient for audit committee financial expertise (ACFIN) is not significant in all models and sensitivity analyses. The results imply that the financial expertise of audit committee members is a not a factor that could significantly contribute to the effectiveness of an audit committee in ensuring high quality of reported earnings. Based on the results, this study is not able to reject the null hypothesis that there is no association between audit committee financial expertise and earnings quality. 
The insignificant results could be due to the possibility that the proportion of financial experts in an audit committee does not necessarily capture the employment of the knowledge and its effectiveness. Saleh et al.'s (2007) findings show that having a higher proportion of financial expertise in an audit committee per se would not necessarily lead to the effectiveness of the audit committee in curbing earnings management of Malaysian firms. However, a combination of high proportion of members with accounting knowledge in audit committee and high frequency of audit committee meetings results in significantly low earnings management practices. Similarly, a recent study by Dhaliwal, Naiker and Navissi (2010) claims that the personal characteristics of audit committee accounting experts could affect their monitoring of accrual quality. Dhaliwal et al. (2010) found that audit committee accounting experts who are independent, hold fewer directorships, and have a lower tenure in their firms have a profound positive impact on accruals quality. In other words, their results suggests that to be effective, audit committee members should not only possess accounting expertise but also be independent, relatively free from commitments to other firms, and be recent appointees.

\subsubsection{Board Size}

From the analyses conducted using the total sample of Malaysian companies, it was found that a smaller board of directors is associated with higher quality of earnings. The significant negative associations between board size (BODSIZE) and quality of reported earnings appear in all models reported in the study. The results are also 
robust in all sensitivity analyses. Based on the results, this study rejects the null hypothesis that there is no association between board size and earnings quality.

However, as with the other corporate governance variables, the result holds only for nonfamily firms. This result is consistent with a number of previous studies (e.g. Eisenberg et al., 1998; Mak and Kusnadi, 2005; Rahman and Ali, 2006; Vafeas, 2000; Yermack, 1996), which suggests that the smaller the board, the more effective it is in its monitoring function. The effectiveness of smaller boards in performing the monitoring function could be due to several reasons. Lipton and Lorsch (1992) argue that smaller boards involves fewer number of directors, and thus easier to be managed and are more organised. When the boards are too big, it would be harder to coordinate the directors' efforts. In addition, smaller board are more effective as they have better communication and more timely decision making (Karamanou and Vafeas, 2005). Furthermore, in smaller boards, the directors have fewer tendencies to free-ride and have greater accountability compared to larger boards.

\subsubsection{Board Independence}

The result of this study does not support the argument that greater involvement of independent board of directors would leads to higher monitoring of managerial activities and result in higher quality of reported earnings. The result shows that there is no significant association between board independence (BODIND) and earnings quality in the total sample of Malaysian companies. Therefore, there is not enough 
evidence to reject the null hypothesis that there is no association between board independence and earnings quality.

This finding is not consistent with prior studies such as Xie et al. (2003) and Peasnell et al. (2005), which find that a higher proportion of independent directors on the board is associated with higher quality of earnings. Nevertheless, the result is similar to the evidence found by Park and Shin (2004) in Canada and Choi et al. (2007) in Korea, which found no significant relationship between outside directors and the quality of earnings. The insignificant result is also similar to the previous studies in Malaysia that did not find any evidence supporting the role of independent directors in constraining earnings management in the country (Abdullah and Nasir, 2004; Rahman and Ali, 2006; Saleh et al., 2005).

The findings of this study suggest that independent directors in Malaysia are not helpful in ensuring high quality of earnings. As a board of directors has diverse responsibilities including monitoring the firm's top executives, approving the company's strategy, and monitoring the internal control over financial reporting; the role of ensuring high quality of earnings may be delegated to firm's audit committees. The ineffectiveness of independent directors in carrying out monitoring function may also due to their lack of expertise, lack of required skills and knowledge in the business environment (Wan-Hussin, 2009). It is also likely that the lack of association between independent directors and earnings quality may be due to the reason that the appointment of independent directors could be influenced by controlling shareholders 
or the CEOs to protect their interests. The independent directors may also be appointed for political reasons, for legitimising business activities, and for contacts and contracts, rather than for expertise and experience (Haniffa and Hudaib, 2006).

\subsubsection{CEO Duality}

This study does not find any significant association between CEO duality (DUALITY) and earnings quality, and therefore null hypothesis of no association between CEO duality and earnings quality is not rejected. The finding suggests that although most of the codes of corporate governance recommend the separation of role of the chairman and that of the CEO, it does not necessarily lead to the improvement in the quality of financial reporting.

Felton and Wong (2004) suggests that splitting the role of CEO and chairman might not result in independent and more effective monitoring if the CEO or chairman is not really independent. For example, in the UK, splitting the role of chairman and the CEO is not effective when a chairman-CEO gives up the CEO roles but stays on as a chairman or a chairman-CEO gives up the chairmanship but continues to serve as a CEO (Felton and Wong, 2004). According to Coombes and Wong (2004), even though separating the roles of chairman and CEO is recommended, it would not give any advantage unless the chairman is committed to performing his duties. 


\subsubsection{Interaction Effect of Family Influence and Corporate Governance on Earnings}

\section{Quality}

This study finds that there is a significant impact of family firms on the relationship between audit committee size and earnings quality and audit committee independence and earnings quality . Specifically, the findings of this study show that audit committee size-earnings quality and audit committee independence-earnings quality relationships are significantly weaker in family firms compared to nonfamily firms. Therefore, the null hypothesis that there is no significant difference between corporate governance-earnings quality relationship in family and nonfamily firms is rejected.

The results of this study suggest that family control mediates the effectiveness of corporate governance mechanisms (in the form of audit committee size and independence) in monitoring firms financial reporting. These results are consistent with Jaggi and Leung (2007), who found that the effectiveness of audit committees is significantly reduced when family members are present on corporate boards. Jaggi and Leung (2007) explain that the appointment of independent members to audit committees is to ensure that there is no undue pressure on audit committee members from individuals with controlling interests. When family members with controlling interests are present on boards, it is unlikely that independent audit committees members will oppose the family members, who appointed them to the corporate board (Jaggi and Leung, 2007). The loyalty of the independent audit committee 
members to the controlling family board members would compromise their effectiveness.

The findings also suggest a substitution effect for family control in family firms. As explained by Bertrand and Schoar (2006), "trust between family members can be a substitute for missing governance and contractual enforcement”. Thus, in family firms, even though the corporate governance mechanisms are weak, tight controls by the family results in high quality of financial reporting. Similarly, Klein, Shapiro and Young (2005) claim that in family firms, greater alignment of ownership and control obviates the need for outside directors. Klein (2005) suggests that in family firm, the role of the board is more of providing service and advice rather than monitoring and control.

\subsection{Chapter Summary}

This chapter provides findings of the empirical analysis including the descriptive, univariate correlation, multivariate and sensitivity analysis. The descriptive analysis reported in this chapter presented the involvement of family through ownership of shares and control over board of directors in Malaysian firms, the extent of corporate governance practices as well as the level of earnings quality of the firms. The univariate analysis documented the difference between earnings quality and corporate governance of family and nonfamily firm. The multivariate analysis provides evidence on the difference between earnings quality of family and nonfamily firms, the association between corporate governance variables and earnings quality, and the 
mediating effect of family influence on corporate governance- earnings quality relationship.

The main findings on the direct effect of family influence and corporate governance on earnings quality shows that family firms have higher quality of earnings relative to nonfamily firms. The result supports the alignment effect within family firms that is consistent with prior studies in the US (Wang, 2006). In addition, the regression results show that audit committee independence and board size are significantly associated with earnings quality in nonfamily firms. The results suggest that a higher proportion of independent audit committee members and a smaller size of the board of directors are associated with higher quality of earnings. The findings are consistent with the agency theory expectation and most of prior findings in the literature.

Examination of the interaction effect of family influence and corporate governance reveals that three corporate governance variables; the size of audit committee, the independence of audit committee and the size of the board of directors have significant associations with earnings quality in nonfamily firms. However, there is no association between any of the corporate governance variables and earnings quality in family firms. The results from both samples suggest that corporate governance variables are associated with earnings quality only in nonfamily firms, suggesting that the effectiveness of corporate governance could be mediated by family influence. Further multivariate analysis that includes interaction variables of corporate governance and family influence confirms the results. 


\section{CHAPTER SIX: SUMMARY AND CONCLUSION}

\subsection{Introduction}

This chapter provides a summary of the present study, highlights the limitations of the study and provides suggestions for future research. This chapter is organised as follows. Section 6.2 presents a summary of the research and implications of the findings. Section 6.3 discusses the limitations of the study. Section 6.4 concludes the thesis outlining the contributions and a number of suggestions for further research.

\subsection{Summary of the Research}

The purpose of this study was to examine the association between family influence and earnings quality, the association between corporate governance and earnings quality, and the mediating impact of family influence on the association between

corporate governance and earnings quality in Malaysia. The study used a sample of 527 companies listed on the Bursa Malaysia over the period 2003-2008 - a total of 3162 firm-year observations.

This study measures earnings quality as the additive inverse of the absolute value of residuals from the estimation of the original and modified cross-sectional Dechow and Dichev (2002) model. A firm is categorised as a family firm if the family members owned more than $20 \%$ of the firm's shares and at least two family members are directors. The corporate governance aspects examined in this study include audit 
committee size, audit committee independence, audit committee meeting frequency, audit committee financial expertise, board size, board independence and CEO duality. This study employs OLS regressions to test the hypotheses. To ensure the robustness of the results, this study performs several sensitivity analyses including using White (1980) adjusted t-statistics, using industry and year dummies to control for industry and year fixed effects, estimating Fama \& MacBeth regressions to mitigate potential time-series correlations of pooled data, and using alternative measures for the family influence and earnings quality.

This study finds that family firms have significantly higher earnings quality than nonfamily firms, supporting the view that significant family ownership and control in a firm provides additional monitoring in a weak capital market. Special characteristics possessed by family firms such as altruism and long-term orientation may contribute to better monitoring in these firms, resulting in higher quality of earnings.

Consistent with the results from previous studies on earnings quality and corporate governance, this study documents significant associations between corporate governance variables and earnings quality. Specifically, this study documents that audit committee size, audit committee independence, and board size are significantly associated with accrual quality. However, the significant association between these corporate governance variables and earnings quality exists only in non-family firms. The results suggest that in nonfamily firms, a higher proportion of independent audit 
committee members and a smaller board of directors provide more effective monitoring on the managers' financial reporting.

By considering interaction variables between family and corporate governance, the study also found that that family influence mediates the effectiveness of these corporate governance mechanisms in monitoring firms financial reporting. These results are consistent with Jaggi and Leung (2007), who find that the effectiveness of audit committees is significantly reduced when family members are present on corporate boards. It could be that when family members with controlling interests are present on boards, it is unlikely that independent audit committee members will oppose them. The loyalty of the independent audit committee members to the controlling family board members might compromise their effectiveness (Jaggi and Leung, 2007).

\subsection{Limitations of the Study}

This study is subject to a number of limitations. First, this study focused on the Malaysian institutional setting. The result should be applicable to other countries with similar business and institutional environment. However, it may not be applicable to other countries with a significantly different institutional and regulatory environment.

Second, the validity of the conclusions drawn in this study depends upon accrual quality as a proper measure of earnings quality. This study measures earnings quality based on the quality of accruals using the original and modified Dechow and Dichev 
(2002) models, thus the result of this study might not generalise to other dimensions of earnings quality. As discussed in Section 3.1.2, there are other measures of earnings quality. Since the measures represent different dimension of earnings quality, the use of such measures may give different results.

In this study, the firms are included based on the availability of data to calculate accrual quality variable. This study includes only companies that have a complete set of data during an eight year period of 2002-2009. Thus, the data might suffer from sample bias towards surviving firms. Firms in the sample are more likely to be larger and more successful than firms that are not included in the sample, as smaller and less successful firms might not survive during the eight year period.

Finally, the corporate governance variables used in this study may be endogenously related to earnings quality. Thus, the coefficient estimates and inferences derived in this study may be biased. Further, the results support associations (or lack thereof) but cannot be interpreted as establishing causality between family firms, corporate governance and earnings quality.

\subsection{Contributions and Suggestions for Future Research}

The present study contributes to the literature by documenting evidence that family firms in Malaysia report higher quality of earnings compared to their nonfamily counterparts, supporting the alignment hypothesis of family ownership and control. This study also documents that corporate governance, in the form of audit committee 
size and independence, and board size, associates with higher earnings quality only for nonfamily firms but not for family firms. The study also concludes that family influence weakens the corporate governance-earnings quality relationship. This conclusion has important implications for countries with significant number of family firms, such as the East Asian countries (Claessens et al., 2000). The impact of the positive features of family influence on earnings quality seems to persist in a context where institutional environment is poor, as family control serves as a substitute for the poor external governance. As family firms are found to have higher quality of earnings, the Malaysian policy makers should analyse the appropriateness of requiring firms to have dispersed ownership structure and independent board of directors. The government should consider that family firms have dominant contributions in the development of the Malaysian economy. Since family firms represent a majority of firms in the country, this study also support the call to address an introduction of corporate governance system that are more appropriate for the firms with different ownership structure in the country.

As suggested in Cascino (2010), future research could provide an extension to this study by examining the economic consequence of financial reporting quality in family firms. The studies can assess whether the higher quality of accounting information in family firms effectively translates into positive capital market outcomes, such as lower cost of capital, higher liquidity and more efficient contracting. 
Johnson and Mitton (2003) found that in Malaysia, politically connected firms had worse stock returns during the early phase of the Asian financial crisis compared to nonpolitical firms. However, politically connected firms are associated with higher stock performance after the imposition of capital controls by the government. Ball (2003) claims that political forces, including the extent of involvement of governments in codifying and enforcing accounting standards, taxes, and political incentives to reduce the volatility of reported income, could affect the quality of financial reporting. As there is a possibility that these political factors could affect the quality of financial reporting, future research could provide a richer analysis by including this factor in analyses examining earnings quality of family firms in Malaysia. For example, future research could examine whether the earnings quality of family firms that are politically connected differs from that of family firms that do not have political connections.

Another important extension to this study would be an examination of family culture and its association with financial reporting quality. As reported in the additional analysis in this study, the influence of Chinese families on earnings quality is different from that of Malay families, suggesting that culture and family values are important predictors of earnings quality in countries with mixed cultures and races. The impact of culture on corporate social reporting in Malaysia was documented in the Haniffa and Cooke (2005) study. Further investigation on the impact of specific family culture and values on the quality of financial reporting may extend existing 
studies on family firms, as well as provide further understanding of the impact of culture on broader financial reporting issues.

Finally, this study examined the relationships between family firms, corporate governance and earnings quality from a positivist perspective, with the application of quantitative assessment techniques. Future research might provide further analysis using qualitative methods to help understand how family ownership and control, as well as corporate governance mechanisms, relate to firms quality of financial reporting. For example, future research could study the role that certain individuals play in accounting choices in family firms, their underlying motivations and the environment or variety of situations that motivates them to make such decisions. 


\section{REFERENCES}

Abbott, L. J., \& Parker, S. (2000). Fraudulent financial reporting: Auditor selection and audit committee characteristics. Auditing: A Journal of Practice \& Theory, 19(2), 47-66.

Abbott, L. J., Parker, S., \& Peters, G. F. (2004). Audit committee characteristics and restatements. Auditing: A Journal of Practice \& Theory, 23(1), 69-87.

Abbott, L. J., Parker, S., Peters, G. F., \& Raghunandan, K. (2003a). The association between audit committee characteristics and audit fees. Auditing: A Journal of Practice \& Theory, 22(2), 17-32.

Abbott, L. J., Parker, S., Peters, G. F., \& Rama, D. V. (2003b). Audit, non-audit and information technology fees: Some empirical evidence. Accounting and the Public Interest, 3(1), 1-20.

Abdullah, S.-N. (2006). Board composition, audit committee and timeliness of corporate financial reports in Malaysia. Corporate Ownership \& Control, $4(2), 33-45$.

Abdullah, S. N., \& Nasir, N. M. (2004). Accrual management and the independence of the board of directors and audit committees. IIUM Journal of Economics and Management, 12(1), 49-80.

Aboody, D., Hughes, J., \& Liu, J. (2005). Earnings quality, insider trading, and cost of capital. Journal of Accounting Research, 43(5), 651-673.

Agrawal, A., \& Chadha, S. (2005). Corporate governance and accounting scandals. Journal of Law \& Economics, 48(2), 317-406.

Ahmad-Zaluki, N. A., \& Wan-Hussin, W. N. (2010). Corporate governance and earnings forecasts accuracy. Asian Review of Accounting, 18(1), 50-67.

Ahmed, A. S., Billings, B. K., \& Morton, R. M. (2004). Extreme accruals, earnings quality, and investor mispricing. SSRN.

Ali, A., Chen, T.-Y., \& Radhakrishnan, S. (2007). Corporate disclosures by family firms. Journal of Accounting and Economics, 44(1-2), 238-286.

Allen, M. P., \& Panian, S. K. (1982). Power, performance, and succession in the large corporation Administrative Science Quarterly, 27(4), 538-547.

Allouche, J., Amann, B., Jaussaud, J., \& Kurashina, T. (2008). The impact of family control on the performance and financial characteristics of family versus nonfamily businesses in Japan: A matched-pair investigation. Family Business Review, 21(4), 315-329. 
AlNajjar, F., \& Riahi-Belkaoui, A. (2001). Growth opportunities and earnings management. Managerial Finance, 27(12), 72-81.

Altman, E. I. (1968). Financial ratios, discriminant analysis and the prediction of corporate bankruptcy. Jounal of Finance, 23(4), 189-209.

Amran, A., \& Devi, S. S. (2008). The impact of government and foreign affiliate influence on corporate social reporting. Managerial Auditing Journal, 23(4), 386-404.

Anderson, R. C., Duru, A., \& Reeb, D. M. (2009). Founders, heirs, and corporate opacity in the United States. Journal of Financial Economics, 92(2), 205-222.

Anderson, R. C., Mansi, S. A., \& Reeb, D. M. (2003). Founding family ownership and the agency cost of debt. Journal of Financial Economics, 68(2), 263-285.

Anderson, R. C., Mansi, S. A., \& Reeb, D. M. (2004). Board characteristics, accounting report integrity, and the cost of debt. Journal of Accounting and Economics, 37(3), 315-342.

Anderson, R. C., \& Reeb, D. M. (2003a). Founding-family ownership and firm performance: Evidence from the S\&P 500. Journal of Finance, 58(3), 13011328.

Anderson, R. C., \& Reeb, D. M. (2003b). Founding-family ownership, corporate diversification and firm leverage. Journal of Law \& Economics, 46(2), 653680 .

Anderson, R. C., \& Reeb, D. M. (2004). Board composition: Balancing family influence in S\&P 500 firms. Administrative Science Quarterly, 49(2), 209237.

Andres, C. (2008). Large shareholders and firm performance: An empirical examination of founding-family ownership. Journal of Corporate Finance, 14(4), 431-445.

Archibald, T. R. (1969). The decision to return to straight-line depreciation. Unpublished Ph.D., The University of Chicago, Illinois, United States.

Arosa, B., Iturralde, T., \& Maseda, A. (2010). Ownership structure and firm performance in non-listed firms: Evidence from Spain. Journal of Family Business Strategy, 1(2), 88-96.

Ashbaugh, H., LaFond, R., \& Mayhew, B. W. (2003). Do nonaudit services compromise auditor independence? Further evidence. The Accounting Review, 78(3), 611-639. 
Ayres, F. L. (1994). Perceptions of earnings quality: What managers need to know. Management Accounting, 75(9), 27-29.

Ball, R., \& Shivakumar, L. (2008). Earnings quality at initial public offerings. Journal of Accounting \& Economics, 45(2/3), 324-349.

Bao, B.-H., \& Bao, D.-H. (2004). Income smoothing, earnings quality and firm valuation. Journal of Business Finance \& Accounting, 31(9/10), 1525-1557.

Barnea, A., Ronen, J., \& Sadan, S. (1976). Classificatory smoothing of income with extraordinary Items. Accounting Review, 51(1), 110-122.

Barragato, C. A., \& Markelevich, A. (2008). Earnings quality following corporate acquisitions. Managerial Finance, 34(5), 304-315.

Barth, E., Gulbrandsen, T., \& Schøne, P. (2005). Family ownership and productivity: The role of owner-management. Journal of Corporate Finance, 11(1-2), 107127.

Barth, E. M., Cram, D. P., \& Karen, K. N. (1999). Accrual and the prediction of future cash flows. SSRN.

Barth, M. E., Beaver, W. H., \& Landsman, W. R. (2001). The relevance of the value relevance literature for financial accounting standard setting: Another view. Journal of Accounting \& Economics, 31(1-3), 77-104.

Barth, M. E., Landsman, W. R., \& Lang, M. H. (2008). International Accounting Standards and Accounting Quality. Journal of Accounting Research, 46(3), 467- 498 .

Bartholomeusz, S., \& Tanewski, G. A. (2006). The Relationship between family firms and corporate governance. Journal of Small Business Management, 44(2), 245-267.

Baxter, P., \& Cotter, J. (2009). Audit committees and earnings quality. Accounting \& Finance, 49(2), 267-290.

Beasley, M. S. (1996). An empirical analysis of the relation between the board of director composition and financial statement fraud. Accounting Review, 71(4), 443-465.

Beasley, M. S., Carcello, J. V., Hermanson, D. R., \& Lapides, P. D. (2000). Fraudulent financial reporting: Consideration of industry traits and corporate governance mechanisms. Accounting Horizons, 14(4), 441-454.

Beattie, V., Brown, S., Ewers, D., \& John, B. (1994). Extraordinary items and income smoothing: A positive accounting approach. Journal of Business Finance \& Accounting, 21(6), 791-811. 
Beatty, A., \& Weber, J. (2006). Accounting discretion in fair value estimates: An examination of SFAS 142 goodwill impairments. Journal of Accounting Research, 44(2), 257-288.

Bebchuk, L. A. (1999). A rent-protection theory of corporate ownership and control. NBER Working Papers No.7203, National Bureau of Economic Research.

Becker, C. L., Defond, M. L., Jiambalvo, J., \& Subramanyam, K. R. (1998). The effect of audit quality on earnings management. Contemporary Accounting Research, 15(1), 1-24.

Becker, G. S. (1981). A treatise on the family. Cambridge, MA: Harvard University Press.

Bédard, J., Chtourou, S. M., \& Courteau, L. (2004). The effect of audit committee expertise, independence, and activity on aggressive earnings management. Auditing: A Journal of Practice \& Theory, 23(2), 13-35.

Beekes, W., Pope, P., \& Young, S. (2004). The link between earnings timeliness, earnings conservatism and board composition: Evidence from the UK. Corporate Governance: An International Review, 12(1), 47-59.

Beneish, M. D., \& Vargus, M. E. (2002). Insider trading, earnings quality, and accrual mispricing. The Accounting Review, 77(4), 755-791.

Bergstrom, T. C. (1989). A fresh look at the rotten kid theorem and other household mysteries. Journal of Political Economy, 97(5), 1138-1159.

Berle, A. A., \& Means, G. C. (1932). The modern corporation and private property. New York: Commerce Clearing House, NY.

Berry, W. D., \& Feldman, S. (1985). Multiple Regression in Practice (Sage University Paper Series on Quantitative Applications in the Social Sciences, 07-050) (Vol. 07-050). Newbury Park, CA: Sage Publications.

Bertrand, M., \& Schoar, A. (2006). The role of family in family firms. The Journal of Economic Perspectives, 20(2), 73-96.

Beuselinck, C., Deloof, M., \& Manigart, S. (2009). Private equity involvement and earnings quality. Journal of Business Finance \& Accounting, 36(5/6), 587615 .

Bhattacharya, U., \& Ravikumar, B. (2001). Capital markets and the evolution of family businesses. The Journal of Business, 74(2), 187-219.

Bhaumik, S. K., \& Gregoriou, A. (2010). 'Family' ownership, tunnelling and earnings management: A review of the literature. Journal of Economic Surveys, 24(4), 705-730. 
Biddle, G. C., Hilary, G., \& Verdi, R. S. (2009). How does financial reporting quality relate to investment efficiency? Journal of Accounting and Economics, 48(23), 112-131.

Blue Ribbon Committee (BRC) (1999). Report and Recommendations of the Blue Ribbon Committee on Improving the Effectiveness of Corporate Audit Committees. New York: New York Stock Exchange.

Bodie, Z., Kane, A., \& Marcus, A. J. (2002). Investments (6th ed.). New York: McGraw-Hill.

Bozec, Y., \& Bozec, R. (2007). Ownership concentration and corporate governance practices: Substitution or expropriation effects? Canadian Journal of Administrative Sciences, 24(3), 182-195.

Bradbury, M., Mak, Y. T., \& Tan, S. M. (2006). Board characteristics, audit committee characteristics and abnormal accruals. Pacific Accounting Review, 18(2), 47-68.

Buckby, S., Dunstan, K. L., \& Savage, R. (2002). A study of the determinants of Australia audit committee effectiveness. Working Paper, Queensland University of Technology.

Bureau of East Asian and Pacific Affairs (2011). Background note: Malaysia. U.S. Department of States: Diplomacy in action Retrieved 12 July 2011, from http://www.state.gov/r/pa/ei/bgn/2777.htm

Burgstahler, D., \& Dichev, I. (1997). Earnings management to avoid earnings decreases and losses. Journal of Accounting and Economics, 24(1), 99-126.

Burkart, M., Panunzi, P., \& Shleifer, A. (2003). Family firms. Journal of Finance, $58(5), 2167-2201$

Bursa Malaysia (2005). Listing requirements. Kuala Lumpur: Bursa Malaysia Berhad.

Bursa Malaysia (2009). Corporate governance guide: Towards boardroom excellence. Kuala Lumpur: Bursa Malaysia Berhad.

Bushman, R., Chen, Q., Engel, E., \& Smith, A. (2004). Financial accounting information, organizational complexity and corporate governance systems. Journal of Accounting \& Economics, 37(2), 167-201.

Bushman, R. M., Piotroski, J. D., \& Smith, A. J. (2011). Capital allocation and timely accounting recognition of economic losses. Journal of Business Finance \& Accounting, 38(1-2), 1-33. 
Cadbury, A. (1992). Report of the committee on the financial aspects of corporate governance. London: Gee Professional Publising Ltd.

Capulong, M. V., Edwards, D., Webb, D., \& Zhuang, J. (2000). Corporate governance and finance in East Asia: A Study of Indonesia, Republic of Korea, Malaysia, Philippines, and Thailand: Volume one (A consolidated report): Asian Development Bank.

Carcello, J. V., Hermanson, D. R., Neal, T. L., \& Riley Jr, R. A. (2002). Board characteristics and audit fees. Contemporary Accounting Research, 19(3), 365-384.

Carcello, J. V., \& Neal, T. L. (2000). Audit committee characteristics and auditor reporting. The Accounting Review, 75(4), 453-467.

Carcello, J. V., \& Neal, T. L. (2003). Audit committee characteristics and auditor dismissal following "new" going-concern reports. The Accounting Review, 78(1), 95-117.

Carlson, S. J., \& Bathala, C. (1997). Ownership differences and firms' income smoothing behavior. Journal of Business Finance \& Accounting, 24(2), 179196.

Cascino, S., Pugliese, A., Mussolino, D., \& Sansone, C. (2010). The influence of family ownership on the quality of accounting information. Family Business Review, 23(3), 246-265.

Casson, M. (1999). The economics of the family firms. Scandinavian Economic History Review, 47(1), 10-23.

Chai, L., \& Hayes, A. F. (2008). A new test of linear hypotheses in OLS regression under heteroscedasticity of unknown form. Journal of Educational and Behavioral Statistics, 33(1), 21-40.

Chan, K., Chan, L. K. C., Jegadeesh, N., \& Lakonishok, J. (2006). Earnings quality and stock returns. Journal of Business, 79(3), 1041-1082.

Chaney, P. K., \& Lewis, C. M. (1998). Income smoothing and underperformance in initial public offerings. Journal of Corporate Finance, 4(1), 1-29.

Chang, J. C., \& Sun, H. L. (2009). Crossed-listed foreign firms' earnings informativeness, earnings management and disclosures of corporate governance information under SOX. The International Journal of Accounting, $44(1), 1-32$.

Chau, G., \& Gray, S. J. (2010). Family ownership, board independence and voluntary disclosure: Evidence from Hong Kong. Journal of International Accounting, Auditing and Taxation, 19(2), 93-109. 
Chen, C., \& Jaggi, B. (2000). Association between independent non-executive directors, family control and financial disclosures in Hong Kong. Journal of Accounting and Public Policy, 19(4), 285-310.

Chen, L. H., Dhaliwal, D. S., \& Trombley, M. A. (2007). The impact of earnings management and tax planning on the information content of earnings. SSRN Working Paper Series.

Chen, S., Chen, X., \& Cheng, Q. (2008). Do family firms provide more or less voluntary disclosure? . Journal of Accounting Research, 46(3), 499-536.

Cheng, C. S. A., Hsieh, S.-J., \& Yip, Y. (2007). Impact of accounting choices on firm valuation and earnings quality. Review of Accounting \& Finance, 6(4), 419441.

Cheng, S. (2008). Board size and the variability of corporate performance. Journal of Financial Economics, 87(1), 157-176.

Cheung, S. Y. L., \& Chan, B. Y. (2004). Corporate governance in Asia. Asia-Pacific Development Journal, 11(2), 1-31.

Chia, Y. M., Lapsley, I., \& Lee, H.-W. (2007). Choice of auditors and earnings management during the Asian financial crisis. Managerial Auditing Journal, 22(2), 177-196.

Choi, J. J., Park, S. W., \& Yoo, S. S. (2007). The value of outside directors: Evidence from corporate governance reform in Korea. Journal of Financial and Quantitative Analysis, 42(4), 941-962.

Choo, T. M., \& Peter, L. N. (1998). Accounting for extraordinary items in Singapore: Empirical findings and international implications. Journal of International Accounting, Auditing and Taxation, 7(2), 215-232.

Chrisman, J. J., Chua, J. H., \& Litz, R. A. (2004). Comparing the agency costs of family and non-family firms: Conceptual issues and exploratory evidence. Entrepreneurship: Theory \& Practice, 28(4), 335-354.

Chu, E. Y., \& Cheah, K. G. (2006). Does ownership structure matter? Evidence from Malaysian equity market. Corporate Ownership \& Control, 4(1), 77-90.

Claessens, S., Djankov, S., Fan, J. P. H., \& Lang, L. H. P. (1999). Expropriation of minority shareholders in East Asia. World Bank Policy Research Working Paper 2088.

Claessens, S., Djankov, S., Fan, J. P. H., \& Lang, L. H. P. (2002). Disentangling the incentive and entrenchment effects of large shareholdings. Journal of Finance, 57(6), 2741-2771. 
Claessens, S., Djankov, S., \& Lang, L. H. P. (2000). The separation of ownership and control in East Asian corporations. Journal of Financial Economics, 58(1-2), 81-112.

Cohen, D. A. (2004). Quality of financial reporting choice: Determinants and economic consequences. Unpublished Ph.D., Northwestern University, Illinois, United States.

Cohen, J., Krishnamoorthy, G., \& Wright, A. (2004). The corporate governance Mosaic and financial reporting quality. Journal of Accounting Literature, 23, 87-152.

Cohen, J. R., Krishnamoorthy, G., \& Wright, A. M. (2008). Form versus substance: The implications for auditing practice and research of alternative perspectives on corporate governance. Auditing: A Journal of Practice \& Theory 27(2), 181-198.

Collier, P., \& Gregory, A. (1999). Audit committee activity and agency costs. Journal of Accounting and Public Policy, 18(4-5), 311-332.

Collins, J. H., Shackelford, D. A., \& Wahlen, J. M. (1995). Bank differences in the coordination of regulatory capital, earnings, and taxes. Journal of Accounting Research, 33(2), 263-291.

Coombes, P., \& Wong, S. C. Y. (2004). Chairman and CEO- One job or two? The McKinsey Quarterly, 2, 43-47.

Davidson, R., Goodwin-Stewart, J., \& Kent, P. (2005). Internal governance structures and earnings management. Accounting and Finance, 45(2), 241-267.

Davidson, S., Stickney, C. P., \& Weil, R. L. (1985). Intermediate Accounting: Concepts, Methods and Use (Fourth ed.). Forthworth: Dryden Press.

Davis, P. (1983). Realizing the potential of the family business. Organizational Dynamics, 12(1), 47-56.

DeAngelo, H., \& DeAngelo, L. (1985). Managerial ownership of voting rights: A study of public corporations with dual classes of common stock. Journal of Financial Economics, 14(1), 33-69.

DeAngelo, H., \& DeAngelo, L. (2000). Controlling stockholders and the disciplinary role of corporate layout policy: A study of the Times Mirror Company. Journal of Financial Economics, 56(2), 153-207.

DeAngelo, H., DeAngelo, L., \& Skinner, D. J. (1994). Accounting choice in troubled companies. Journal of Accounting and Economics, 17(1-2), 113-143. 
DeAngelo, L. E. (1981). Auditor size and audit quality. Journal of Accounting \& Economics, 3(3), 183-199.

DeAngelo, L. E. (1986). Accounting numbers as market valuation substitutes: A study of management buyouts of public stockholders. Accounting Review, 61(3), 400-420.

Dechow, M. P., \& Schrand, C. M. (2004). Earnings Quality. New York: The Research Foundation of CFA Institute.

Dechow, P. M. (1994). Accounting earnings and cash flows as measures of firm performance : The role of accounting accruals. Journal of Accounting and Economics, 18(1), 3-42.

Dechow, P. M., \& Dichev, I. D. (2002). The quality of accruals and earnings: the role of accrual estimation errors. Accounting Review, 77(4), 35-59.

Dechow, P. M., Kothari, S. P., \& L. Watts, R. (1998). The relation between earnings and cash flows. Journal of Accounting and Economics, 25(2), 133-168.

Dechow, P. M., Sloan, R. G., \& Sweeney, A. P. (1995). Detecting earnings management. The Accounting Review, 70(2), 193-225.

Dechow, P. M., Sloan, R. G., \& Sweeney, A. P. (1996). Causes and consequences of earnings manipulation: An analysis of firms subject to enforcement actions by the SEC. Contemporary Accounting Research, 13(1), 1-36.

DeFond, M. L., Hann, R. N., \& Hu, X. (2005). Does the market value financial expertise on audit committees of board of directors? . Journal of Accounting Research, 43(2), 153-193.

DeFond, M. L., \& Jiambalvo, J. (1991). Incidence and circumstances of accounting errors. Accounting Review, 66(3), 643-655.

DeFond, M. L., \& Jiambalvo, J. (1994). Debt convenant violation and manipulation of accruals. Journal of Accounting \& Economics, 17(1/2), 145-176.

Demb, A., \& Neubauer, F. F. (1992). The corporate board: Confrontng the paradoxes. Long Range Planning, 25(3), 9-20.

Dempsey, S. J., Hunt III, H. G., \& Schroeder, N. W. (1993). Earnings management and corporate ownership structure: An examination of extraordinary item reporting. Journal of Business Finance \& Accounting, 20(4), 479-500.

Dempster, G. M. (2008). Determining earnings quality: a multi-factor model approach. Journal of Academy of Business and Economics, 8(1), 152-157. 
Demsetz, H., \& Lehn, K. (1985). The structure of corporate ownership: Causes and consequences. The Journal of Political Economy, 93(6), 1155-1577.

Dezoort, F. T. (1998). An analysis of experience effects of audit committee members' oversight judgments. Accounting, Organizations and Society, 23(1), 1-21.

Dezoort, F. T., Hermanson, D. R., Archambeault, S., \& Reed, S. A. (2002). Audit committee effectiveness: A synthesis of the empirical audit committee literature. Journal of Accounting Literature, 21(1), 38-75.

Dhaliwal, D. A. N., Naiker, V. I. C., \& Navissi, F. (2010). The association between accruals quality and the characteristics of accounting experts and mix of expertise on audit committees. Contemporary Accounting Research, 27(3), 787-827.

Ding, Y., Zhang, H., \& Zhang, J. (2007). Private vs state ownership and earnings management: Evidence from Chinese listed companies. Corporate Governance: An International Review, 15(2), 223-238.

Doyle, J., Ge, W., \& McVay, S. (2007). Accruals quality and internal control over financial reporting. The Accounting Review, 82(5), 1141-1170.

Doyle, J. T., Lundholm, R. J., \& Soliman, M. T. (2003). The predictive value of expenses excluded from pro forma earnings. Review of Accounting Studies, 8(2-3), 145-174.

DuCharme, L., Malatesta, P., \& Sefcik, S. (2001). Earnings management: IPO valuation and subsequent performance. Journal of Accounting, Auditing \& Finance, 16(4), 369-396.

Durnev, A., \& Kim, E. H. (2005). To steal or not to steal: Firm attributes, legal environment, and valuation. The Journal of Finance, 60(3), 1461-1493.

Dutta, S., \& Gigler, F. (2002). The effect of earnings forecasts on earnings management. Journal of Accounting Research, 40(3), 631-655.

Dyer, W. G. J. (2006). Examining the "family effect" on firm performance. Family Business Review, 19(4), 253-273.

Easton, P. D., Eddey, P. H., \& Harris, T. S. (1993). An investigation of revaluations of tangible long-lived assets. Journal of Accounting Research, 31(Supplement), 1-38.

Economic Planning Unit (1991). The second outline perspective plan 1991-2000. Kuala Lumpur, Malaysia: Economic Planning Unit, Prime Minister's Department. 
Eisenberg, T., Sundgren, S., \& Wells, M. T. (1998). Larger board size and decreasing firm value in small firms. Journal of Financial Economics 48(1), 35-54.

Ervin, L. B., Keith, F. S., \& Tracy, S. M. (1998). Earnings management using asset sales: An international study of countries allowing noncurrent asset revaluation. Journal of Business Finance \& Accounting, 25(9/10), 1287-1317.

Eshel, I., Samuelson, L., \& Shaked, A. (1998). Altruists, egoists, and hooligans in a local interaction model. American Economic Review, 88(1), 157-179.

Faccio, M., \& Lang, L. H. P. (2002). The ultimate ownership of Western European corporations. Journal of Financial Economics, 65(3), 365-395.

Faccio, M., Lang, L. H. P., \& Young, L. (2001). Dividends and expropriation. The American Economic Review, 91(1), 54-78.

Fama, E. F., \& French, K. R. (2002). Testing tradeoff and pecking order predictions about dividends and debt. Review of Financial Studies, 15(1), 1-33.

Fama, E. F., \& Jensen, M. C. (1983a). Agency problems and residual claims. Journal of Law \& Economics, 26(2), 325-344.

Fama, E. F., \& Jensen, M. C. (1983b). Separation of ownership and control. Journal of Law \& Economics, 26(2), 301-326.

Fama, E. F., \& MacBeth, J. D. (1973). Risk, return and equilibrium: Empirical tests. Journal of Political Economy, 81(3), 607-636.

Fan, J. P. H., \& Wong, T. J. (2002). Corporate ownership structure and the informativeness of accounting earnings in East Asia. Journal of Accounting and Economics, 33(3), 401-425.

Felton, R. F., \& Wong, S. C. F. (2004). How to separate the roles of chairman and CEO. McKinsey Quarterly, 4, 49-57.

Finance Committee on Corporate Governance (2000). Malaysian Code on Corporate Governance. Kuala Lumpur: Securities Commission of Malaysia.

Firth, M., Fung, P. M. Y., \& Rui, O. M. (2007). Ownership, two-tier board structure, and the informativeness of earnings - Evidence from China. Journal of Accounting and Public Policy, 26(4), 463-496.

Flynn, R. S. (2008). Audit committee compensation and perceived earnings quality: A preliminary investigation. International Journal of Business Research, 8(2), 146-152.

Fong, K. (2007a). Top Transmile execs alerted? The Star. 1 June 2007 [Online]. 
http://biz.thestar.com.my/news/story.asp?file=/2007/6/1/business/17904454\&sec=bu siness Accessed: 23 Jan 2010,

Fong, K. (2007b). Transmile share price rebounds. The Star. 5 June 2007 [Online]. http://biz.thestar.com.my/news/story.asp?file $=/ 2007 / 6 / 5 /$ business $/ 17933314 \& s e c=b u$ siness Accessed: 23 Jan 2010,

Forker, J. J. (1992). Corporate governance and disclosure quality. Accounting \& Business Research, 22(86), 111-124.

Francis, J., Huang, A. H., Rajgopal, S., \& Zang, A. Y. (2008). CEO reputation and earnings quality. Contemporary Accounting Research, 25(1), 109-147.

Francis, J., LaFond, R., Olsson, M. P., \& Schipper, K. (2004). Costs of equity and earnings attributes. The Accounting Review, 79(4), 967-1010.

Francis, J., LaFond, R., Olsson, P., \& Schipper, K. (2005). The market pricing of accruals quality. Journal of Accounting and Economics, 39(2), 295-327.

Francis, J., Schipper, K., \& Vincent, L. (2003). The relative and incremental explanatory power of earnings and alternative (to earnings) performance measures for returns. Contemporary Accounting Research, 20(1), 121-164.

Francis, J. R., Maydew, E. L., \& Sparks, H. C. (1999). The role of Big 6 auditors in the credible reporting of accruals. Auditing: A Journal of Practice \& Theory, $18(2), 17-34$.

Francis, J. R., \& Wang, D. (2008). The joint effect of investor protection and Big 4 audits on earnings quality around the world. Contemporary Accounting Research, 25(1), 157-191.

Frankel, R. M., Johnson, M. F., \& Nelson, K. K. (2002). The relation between auditors' fees for nonaudit services and earnings management. The Accounting Review, 77(Supplement), 71-105.

Friedlan, J. M. (1994). Accounting choices of issuers of initial public offerings. Contemporary Accounting Research, 11(1), 1-31.

Gabrielsen, G., Gramlich, J. D., \& Plenborg, T. (2002). Managerial ownership, information content of earnings, and discretionary accruals in a non-U.S. setting. Journal of Business Finance \& Accounting, 29(7/8), 967-988.

García-Lara, J. M., García-Osma, B., \& Neophytou, E. (2009). Earnings quality in ex-post failed firms. Accounting \& Business Research, 39(2), 119-138.

García Lara, J. M., García Osma, B., \& Penalva, F. (2007). Board of directors' characteristics and conditional accounting conservatism: Spanish evidence. European Accounting Review, 16(4), 727-755. 
Gaver, J. J., \& Gaver, K. M. (1998). The relation between nonrecurring accounting transactions and CEO cash compensation. The Accounting Review, 73(2), 235-253.

Gaver, J. J., Gaver, K. M., \& Austin, J. R. (1995). Additional evidence on bonus plans and income management. Journal of Accounting and Economics, 19(1), $3-28$.

Gendron, Y., \& Bédard, J. (2006). On the constitution of audit committee effectiveness. Accounting, Organizations and Society, 31(3), 211-239.

Ghazali, N. A. M., \& Weetman, P. (2006). Perpetuating traditional influences: Voluntary disclosure in Malaysia following the economic crisis. Journal of International Accounting, Auditing and Taxation, 15 (2), 226-248.

Gibson, M. S. (2003). Is corporate governance ineffective in emerging markets? Journal of Financial and Quantitative Analysis, 38(1), 231-250.

Gill-de-Albornoz, B., \& Illueca, M. (2005). Earnings management under price regulation: Empirical evidence from the Spanish electricity industry. Energy Economics, 27(2), 279-304.

Givoly, D., Hayn, C., \& Katz, S. (2010). Does public ownership of equity improve earnings quality? The Accounting Review, 85(1), 195-225.

Godfrey, J. M., \& Jones, K. L. (1999). Political cost influence on income smoothing via extraordinary item classification. Accounting \& Finance, 39(3), 229-254.

Gomez-Mejia, L., Nunez-Nickel, M., \& Gutierrez, I. (2001). The role of family ties in agency contracts. Academy of Management Journal, 44(1), 81-95.

Goodstein, J., Gautam, K., \& Boeker, W. (1994). The effects of board size and diversity on strategic change. Strategic Management Journal, 15(3), 241-250.

Greenberg, R. R., Johnson, G. L., \& Ramesh, K. (1986). Earnings versus cash flow as a predictor of future cash flow measures. Journal of Accounting, Auditing \& Finance, 1(4), 266-277.

Guay, W. R., Kothari, S. P., \& Watts, R. L. (1996). A market-based evaluation of discretionary accrual models. Journal of Accounting Research, 34(Supplement), 83-105.

Gul, F. A., Fung, S. Y. K., \& Jaggi, B. (2009). Earnings quality: Some evidence on the role of auditor tenure and auditors' industry expertise. Journal of Accounting and Economics, 47(3), 265-287. 
Gul, F. A., Lynn, S. G., \& Tsui, J. S. L. (2002). Audit quality, management ownership, and the informativeness of accounting earnings. Journal of Accounting, Auditing \& Finance, 17(1), 25-49.

Gupta, M., \& Fields, L. (2009). Board independence and corporate governance: Evidence from director resignations. Journal of Business Finance \& Accounting, 36(1/2), 161-184.

Haber, J., \& Braunstein, A. (2008). Earnings quality ratings and corporate governance: A comparison of two models. The Journal of Theoretical Accounting Research, 3(2), 44-56.

Habib, A. (2005). Firm-specific determinants of income smoothing in Bangladesh: An empirical evaluation. Advances in International Accounting, 18, 53-71.

Habib, A., \& Azim, I. (2008). Corporate governance and the value-relevance of accounting information: Evidence from Australia. Accounting Research Journal, 21(2), 167-194.

Hampel, S. R. (1998). Committee on corporate governance: Final report. London: Gee Publishing.

Haniffa, R. M., \& Cooke, T. E. (2002). Culture, corporate governance and disclosure in Malaysian corporations. Abacus, 38(3), 317-349.

Haniffa, R. M., \& Cooke, T. E. (2005). The impact of culture and governance on corporate social responsibility. Journal of Accounting and Public Policy, 24(5), 391-430.

Haniffa, R. M., \& Hudaib, M. (2006). Corporate governance structure and performance of Malaysian listed companies. Journal of Business Finance \& Accounting, 33(7/8), 1034-1062.

Haque, M. S. (2003). The role of the state in managing ethnic tensions in Malaysia: A critical discourse. American Behavioral Scientist, 47(3), 240-266.

Harris, T. S., Lang, M., \& Moller, H. P. (1994). The value relevance of German accounting measures: An empirical analysis. Journal of Accounting Research, 32(2), 187-209.

Hashim, H. A., \& Devi, S. (2009). Board characteristics, ownership structure and earnings quality: Malaysian evidence. In M. Tsamenyi \& S. Uddin (Eds.), Corporate Governance in Less Developed and Emerging Economies (Research in Accounting in Emerging Economies, Volume 8) (pp. 97-123): Emerald Group Publishing Limited. 
Hawksworth, J., \& Cookson, G. (2008). The World in 2050- Beyond the BRICs: A broader look at emerging market growth perspectives. London, UK: PricewaterhouseCoopers.

Healy, M. P., \& Wahlen, M. J. (1999). A review of the earnings management literature and its implications for standard setting. Accounting Horizons, 13(4), 365-383.

Healy, P. M. (1985). The effect of bonus schemes on accounting decisions. Journal of Accounting and Economics, 7(1-3), 85-107.

Henning, S. L., Shaw, W. H., \& Stock, T. (2004). The amount and timing of goodwill write-offs and revaluations: Evidence from U.S. and U.K. firms. Review of Quantitative Finance \& Accounting, 23(2), 99-121.

Hermanns, S. (2006). Financial information and earnings quality: A literature review. SSRN Working Paper Series.

Herrmann, D., \& Inoue, T. (1996). Income smoothing and incentives by operating condition: An empirical test using depreciation changes in Japan. Journal of International Accounting, Auditing \& Taxation, 5(2), 161-177.

Ho, S. S. M., \& Wong, K. S. (2001). A study of the relationship between corporate governance structures and the extent of voluntary disclosure. Journal of International Accounting, Auditing and Taxation, 10(2), 139-156.

Hodge, F. D. (2003). Investors' perceptions of earnings quality, auditor independence, and the usefulness of audited financial information. Accounting Horizons, 17(Supplement), 37-48.

Holan, P. M. d., \& Sanz, L. (2006). Protected by the family? How closely held family firms protect minority shareholders. Journal of Business Research, 59(3), 356-359.

Holthausen, R. W., Larcker, D. F., \& Sloan, R. G. (1995). Annual bonus schemes and the manipulation of earnings. Journal of Accounting and Economics, 19(1), $29-74$.

Hung, M. (2001). Accounting standards and value relevance of financial statements: An international analysis. Journal of Accounting and Economics, 30(3), 401420.

Hutchinson, M., \& Leung, S. (2007). An investigation of factors influencing the association between top management ownership and earnings management. Journal of Contemporary Accounting \& Economics, 3(2), 130-153.

Ibrahim, H., \& Samad, F. A. (2010). Family business in emerging markets: The case of Malaysia. African Journal of Business Management, 4(13), 2586-2595. 
International Monetary Fund (2010). World Economic Outlook Database, October 2010: Nominal GDP list of countries. Data for the year 2010.

Jaggi, B., \& Baydoun, N. (2001). Evaluation of extraordinary and exceptional ietms disclosed by Hong Kong companies. Abacus, 37(2), 217-232.

Jaggi, B., Chin, C.-L., Lin, H.-W. W., \& Lee, P. (2006). Earnings forecast disclosure regulation and earnings management: Evidence from Taiwan IPO firms. Review of Quantitative Finance and Accounting, 26(3), 275-299.

Jaggi, B., \& Lee, P. (2002). Earnings management response to debt convenant violations and debt restructuring. Journal of Accounting, Auditing \& Finance, 17(4), 295-324.

Jaggi, B., \& Leung, S. (2007). Impact of family dominance on monitoring of earnings management by audit committees: Evidence from Hong Kong. Journal of International Accounting, Auditing and Taxation, 16(1), 27-50.

Jaggi, B., Leung, S., \& Gul, F. (2009). Family control, board independence and earnings management: Evidence based on Hong Kong firms. Journal of Accounting and Public Policy, 28(4), 281-300.

Jaggi, B., \& Tsui, J. (2007). Insider trading, earnings management and corporate governance: Empirical evidence based on Hong Kong firms. Journal of International Financial Management \& Accounting, 18(3), 192-222.

James, D. R., \& Soref, M. (1981). Profit constraints on managerial autonomy: Managerial theory and the unmaking of the corporation president American Sociological Review, 46(1), 1-18.

James, H. S. (1999). Owner as manager, extended horizons and the family firms. International Journal of the Economics of Business, 1(6), 41-56.

Jasani, N. K. (2002). Malaysia's family businesses: The family \& the business international survey report: Shamshir Jasani Grant Thorton \& Malaysian Institute of Management.

Jensen, M. C. (1993). The modern industrial revolution, exit and the failure of internal control system. Jounal of Finance, 48(3), 831-880.

Jensen, M. C., \& Meckling, W. H. (1976). Theory of the firm: Managerial behavior, agency costs and ownership structure. Journal of Financial Economics, 3(4), 305-360.

Jian, M. (2003). Earnings management and tunneling through related party transactions: Evidence from Chinese corporate groups. Unpublished Ph.D., Hong Kong University of Science and Technology (People's Republic of China), Hong Kong. 
Jiang, W., Lee, P., \& Anandarajan, A. (2008). The association between corporate governance and earnings quality: Further evidence using the GOV-Score. Advances in Accounting, 24(2), 191-201.

Jiraporn, P., \& DaDalt, P. J. (2009). Does founding family control affect earnings management? Applied Economics Letters, 16(2), 113-119.

John, K., \& Senbet, L. W. (1998). Corporate governance and board effectiveness. Journal of Banking \& Finance, 22(4), 371-403.

Johnson, S., \& Mitton, T. (2003). Cronyism and capital controls: Evidence from Malaysia. Journal of Financial Economics, 67(2), 351-382.

Johnson, V. E., Khurana, I. K., \& Reynolds, J. K. (2002). Audit-firm tenure and the quality of financial reports. Contemporary Accounting Research, 19(4), 637660.

Jones, J. J. (1991). Earnings management during import relief investigations. Journal of Accounting Research, 29(2), 193-228.

Joos, P., \& Lang, M. (1994). The effects of accounting diversity: Evidence from the European Union. Journal of Accounting Research, 32(Supplement), 141-168.

Jordan, E. C., Clark, J. S., \& Vann, E. C. (2007). Using goodwill impairment to effect the earnings management during SFAS No. 142's year of adoption and later. Journal of Business and Economic Research, 5(1), 23-30.

Jung, K., \& Kwon, S. Y. (2002). Ownership structure and earnings informativeness: Evidence from Korea. International Journal of Accounting, 37(3), 301-325.

Karamanou, I., \& Vafeas, N. (2005). The association between corporate boards, audit committees, and management earnings forecasts: An empirical analysis. Journal of Accounting Research, 43(3), 453-486.

Kasznik, R. (1999). On the association between voluntary disclosure and earnings management. Journal of Accounting Research, 37(1), 57.

Katz, S. P. (2009). Earnings quality and ownership structure: The role of private equity sponsors. Accounting Review, 84(3), 623-658.

Keating, A. S., \& Zimmerman, J. L. (2000). Depreciation-policy changes: Tax, earnings management, and investment opportunity incentives. Journal of Accounting and Economics, 28(3), 359-389.

Key, K. G. (1997). Political cost incentives for earnings management in the cable television industry. Journal of Accounting \& Economics, 23(3), 309-337. 
Kim, E. (2006). The impact of family ownership and capital structures on productivity performance of Korean manufacturing firms: Corporate governance and the "chaebol problem". Journal of the Japanese and International Economies, 20(2), 209-233.

Kim, J.-B., \& Yi, C. H. (2006). Ownership structure, business group affiliation, listing status, and earnings management: Evidence from Korea. Contemporary Accounting Research, 23(2), 427-464.

Klai, N. (2010). Corporate governance and financial reporting quality: The case of Tunisian firms. International Business Research, 4(1), 158-166.

Klapper, L. F., \& Love, I. (2004). Corporate governance, investor protection, and performance in emerging markets. Journal of Corporate Finance, 10(5), 703728.

Klein, A. (2002). Audit committee, board of director characteristics, and earnings management. Journal of Accounting \& Economics, 33(3), 375-400.

Klein, P., Shapiro, D., \& Young, J. (2005). Corporate governance, family ownership and firm value: The Canadian evidence. Corporate Governance: An International Review, 13(6), 769-784.

Koh, P.-S. (2003). On the association between institutional ownership and aggressive corporate earnings management in Australia. The British Accounting Review, 35(2), 105-128.

Koiranen, M. (2002). Over 100 years of age but still entrepreneurially active in business: Exploring the values and family characteristics of old Finnish family firms. Family Business Review, 15(3), 175-187.

Korczak, A., \& Korczak, P. (2009). Corporate Ownership and the Information Content of Earnings in Poland. Applied Financial Economics, 19(9), 703-717.

Krishnan, G., \& Visvanathan, G. (2009). Do auditors price audit committee's expertise? The case of accounting versus nonaccounting financial experts. Journal of Accounting, Auditing \& Finance, 24(1), 115-144.

Krishnan, G. V. (2003). Does big 6 auditor industry expertise constrain earnings management? Accounting Horizons, 17 (Supplement), 1-16.

Krishnan, G. V., Srinidhi, B., \& Su, L. (2008). Inventory policy, accruals quality and information risk. Review of Accounting Studies, 13(2-3), 369-410.

Krishnan, J. (2005). Audit committee quality and internal control: An empirical analysis. The Accounting Review, 80(2), 649-675. 
Kwak, W., \& Armitage, J. (2009). Earnings informativeness and ownership structure in Japan. Journal of Applied Business Research, 25(1), 13-20.

La Porta, R., Lopez-de-Silanes, F., Shleifer, A., \& Vishny, R. (1999). Corporate ownership around the world. Journal of Finance, 54(2), 471-517.

Labelle, R., Gargouri, R. M., \& Francoeur, C. (2010). Ethics, diversity management, and financial reporting quality. Journal of Business Ethics, 93(2), 335-353.

Lang, M., Raedy, J. S., \& Wilson, W. (2006). Earnings management and cross listing: Are reconciled earnings comparable to US earnings? Journal of Accounting \& Economics, 42(1/2), 255-283.

Lang, M., Raedy, J. S., \& Yetman, M. H. (2003). How representative are firms that are cross-listed in the United States? An analysis of accounting quality. Journal of Accounting Research, 41(2), 363-386.

Larcker, D. F., Richardson, S. A., \& Tuna, İ. (2007). Corporate governance and accounting outcomes. The Accounting Review, 83(4), 963-1008.

Le Breton-Miller, I., \& Miller, D. (2006). Why do some family businesses outcompete? Governance, longterm orientations, and sustainable capability. Entrepreneurship Theory \& Practice, 30(6), 731-746.

Lee, H. G. (2000). Ethnic relations in Peninsular Malaysia: The cultural and economic dimensions. Singapore: Institute of Southeast Asian Studies.

Lee, H. Y., Mande, V., \& Ortman, R. (2004). The effect of audit committee and board of director independence on auditor resignation. Auditing: A Journal of Practice \& Theory 23(2), 131-146.

Lee, J. (2006). Family firm performance: Further evidence. Family Business Review, 19(2), 103-114.

Leftwich, R., Watts, R. L., \& Zimmerman, J. L. (1981). Voluntary corporate disclosure: The case of interim reporting. Journal of Accounting Research, 19(Supplement), 50-77.

Leung, S., \& Horwitz, B. (2004). Director ownership and voluntary segment disclosure: Hong Kong evidence. Journal of International Financial Management and Accounting, 15(3), 235-260.

Leuz, C., Nanda, D., \& Wysocki, P. D. (2003). Earnings management and investor protection: An international comparison. Journal of Financial Economics, 69(3), 505-527.

Leuz, C., \& Verrecchia, R. E. (2000). The economic consequences of increased disclosure. Journal of Accounting Research, 38(3), 91-124. 
Levitt, A. (1998). The importance of high quality accounting standards. Accounting Horizons, 12(1), 79-82.

Lim, M. H. (1981). Ownership and control of the one hundred largest corporations in Malaysia. Kuala Lumpur: Oxford University Press.

Lin, J. W., Li, J. F., \& Yang, J. S. (2006). The effect of audit committee performance on earnings quality. Managerial Auditing Journal, 21(9), 921-933.

Lins, K. V. (2003). Equity ownership and firm value in emerging markets. Journal of Financial \& Quantitative Analysis, 38(1), 159-184.

Lipton, M., \& Lorsch, J. W. (1992). A modest proposal for improved corporate governance. Business Lawyer, 48(1), 59-77.

Low, L. C. (2002). Gains from increased voluntary disclosure in corporate reporting. The Star Biz Weekly, 3 August 2002.

Machuga, S., \& Teitel, K. (2007). The effects of the Mexican corporate governance code on quality of earnings and its components. Journal of International Accounting Research, 6(1), 37-55.

Machuga, S., \& Teitel, K. (2009). Board of director characteristics and earnings quality surrounding implementation of a corporate governance code in Mexico. Journal of International Accounting, Auditing and Taxation, 18(1), $1-13$.

Mak, Y. T., \& Kusnadi, Y. (2005). Size really matters: Further evidence on the negative relationship between board size and firm value. Pacific-Basin Finance Journal, 13(3), 301-318.

Mangena, M., \& Tauringana, V. (2008). Audit committees and voluntary external auditor involvement in UK interim reporting. International Journal of Auditing, 12(1), 45-63.

Martínez, J. I., Stöhr, B. S., \& Quiroga, B. F. (2007). Family ownership and firm performance: Evidence from public companies in Chile. Family Business Review, 20(2), 83-94.

Maury, B. (2006). Family ownership and firm performance: Empirical evidence from Western European corporations. Journal of Corporate Finance, 12(2), 321341.

McConaughy, D. L., Matthews, C. H., \& Fialko, A. S. (2001). Founding family controlled firms: Performance, risk, and value. Journal of Small Business Management, 39(1), 31-49. 
McConaughy, D. L., Walker, M. C., Henderson Jr, G. V., \& Mishra, C. S. (1998). Founding family controlled firms: Efficiency and value. Review of Financial Economics, 7(1), 1-19.

McMullen, D. A., \& Raghunandan, K. (1996). Enhancing audit committee effectiveness. Journal of Accountancy, 182(2), 79-81.

McNichols, M. F. (2002). Discussion of the quality of accruals and earnings: The role of accrual estimation errors. The Accounting Review, 77(Supplement), 61-69.

McNichols, M. F., Wilson, G. P., \& DeAngelo, L. (1988). Evidence of earnings management from the provision for bad debts. Journal of Accounting Research, 26(Supplement), 1-31.

Menon, K., \& Williams, J. D. (1994). The use of audit committee for monitoring. Journal of Accounting and Public Policy, 13(2), 121-139.

Miller, D., \& Le Breton-Miller, I. (2006). Family governance and firm performance: Agency, stewardship, and capabilities. Family Business Review, 19(1), 73-87.

Mitton, T. (2002). A cross-firm analysis of the impact of corporate governance on the East Asian financial crisis. Journal of Financial Economics, 64(2), 215-241.

Mok, H. M. K., \& Lam, K., Cheung, I. (1992). Family control and return covariation in Hong Kong's common stocks Journal of Business Finance \& Accounting, 19(2), 277-293.

Monks, R. A. G. (1994). Relationship investing. Corporate Governance, 2(2), 58-76.

Morck, R., Shleifer, A., \& Vishny, R. (1988). Managerial ownership and market valuation: An empirical analysis. Journal of Financial Economics, 20, 293315 .

Morck, R. K., Stangeland, D. A., \& Yeung, B. (2000). Inherited wealth, corporate control and economic growth: the Canadian disease. In R. K. Morck (Ed.), Concentrated corporate ownership (pp. 319-369). Chicago: University of Chicago Press.

Morris, R. D., Pham, T., \& Gray, S. J. (2011). The value relevance of transparency and corporate governance in Malaysia before and after the Asian financial crisis. Abacus, 47(2), 205-233.

Moyer, S. E. (1990). Capital adequacy ratio regulations and accounting choices in commercial banks. Journal of Accounting \& Economics, 13(2), 123-154.

Myers, J. N., Myers, L. A., \& Omer, T. C. (2003). Exploring the term of the auditorclient relationship and the quality of earnings: A case for mandatory auditor rotation? Accounting Review, 78(3), 779-799. 
National Association of Corporate Directors (NACD) (1999). Report of the NACD Blue Ribbon Commission on audit committees. Washington, D.C.: NACD.

Niu, F. F. (2006). Corporate governance and the quality of accounting earnings: A Canadian perspective. International Journal of Managerial Finance, 2(4), 302-327.

OECD (1999). Corporate Governance in Asia: A Comparative Perspective. Korea: Korea Develpment Institute.

Organisation for Economic Co-operation and Development (2004). OECD Principles of Corporate Governance. Paris: OECD.

Ow-Yong, K., \& Guan, C. K. (2000). Corporate governance codes: A comparison between Malaysia and the UK. Corporate Governance: An International Review, 8(2), 125-132.

Pallant, J. (2007). SPSS survival manual: A step by step guide to data analysis using SPSS for Windows (Version 15). NSW: Allen \& Unwin.

Park, Y. W., \& Shin, H.-H. (2004). Board composition and earnings management in Canada. Journal of Corporate Finance, 10(3), 431- 457.

Patelli, L., \& Prencipe, A. (2007). The relationship between voluntary disclosure and independent directors in the presence of a dominant shareholder. European Accounting Review, 16(1), 5-33.

Peasnell, K. V., Pope, P. F., \& Young, S. (2000). Detecting earnings management using cross-sectional abnormal accruals models. Accounting and Business Research, 30(4), 313-326.

Peasnell, K. V., Pope, P. F., \& Young, S. (2005). Board monitoring and earnings management: Do outside directors influence abnormal accruals? Journal of Business Finance \& Accounting, 32(7/8), 1311-1346.

Peng, M., \& Jiang, Y. (2006). Family ownership and control in large firms: The good, the bad, the irrelevant - and why. University of Michigan.

Penman, S. H., \& Zhang, X.-J. (2002). Accounting conservatism, the quality of earnings, and stock returns. The Accounting Review, 77(2), 237-264.

Pergola, T., Joseph, G., \& Jenzarli, A. (2009). Effects of corporate governance and board equity ownership on earnings quality. Academy of Accounting and Financial Studies Journal, 13(4), 87-114.

Persons, O. S. (2005). The relation between the new corporate governance rules and the likelihood of financial statement fraud. Review of Accounting \& Finance, $4(2), 125-148$. 
Petra, S. (2007). The effects of corporate governance on the informativeness of earnings. Economics of Governance, 8(2), 129-152.

Praet, A. (2007). Large blockholders: Do family firms differ from others? Evidence from the Belgian Stock Market. Katholieke Universiteit Brussels, Brussels.

Prencipe, A., \& Bar-Yosef, S. (2011). Corporate governance and earnings management in family-controlled companies. Journal of Accounting, Auditing and Finance, 26(2), 199-227.

Prencipe, A., Markarian, G., \& Pozza, L. (2008). Earnings management in family firms: Evidence from R\&D cost capitalization in Italy. Family Business Review, 21(1), 71-88.

PricewaterhouseCoopers/IIA (2000). Improving audit committee performance: What works best (Second ed.). Altamonte Springs, F.L.: IIA Research Foundation.

Raghunandan, K., Read, W. J., \& Rama, D. V. (2001). Audit committee composition, "gray directors", and interaction with internal auditing. Accounting Horizons 15(2), 105-118.

Rahman, R. A. (2006). Effective Corporate Governance. Shah Alam, Malaysia: University Publication Centre (UPENA).

Rahman, R. A., \& Ali, F. H. M. (2006). Board, audit committee, culture and earnings management: Malaysian evidence. Managerial Auditing Journal, 21(7), 783804.

Rahman, R. A., \& Haniffa, R. M. (2005). The effect of role duality on corporate performance in Malaysia. Corporate Ownership \& Control, 2(2), 40-47.

Rainsbury, E. A., Bradbury, M., \& Cahan, S. F. (2009). The impact of audit committee quality on financial reporting quality and audit fees. Journal of Contemporary Accounting \& Economics, 5(1), 20-33.

Raonic, I., McLeay, S., \& Asimakopoulos, I. (2004). The timeliness of income recognition by European companies: An analysis of institutional and market complexity. Journal of Business Finance \& Accounting, 31(1-2), 115-148.

Redding, S. G. (1996). Weak organisations and strong linkages: Managerial ideology and Chinese family networks Berlin: Walter de Gruyter.

Revsine, L., Collins, D. W., \& Johnson, W. B. (2002). Financial Reporting and Analysis. Upper Saddle River, NJ: Prentice Hall.

Reza, M. M. (2003). Earnings management in response to the introduction of the Australian gold tax. Contemporary Accounting Research, 20(4), 747-774. 
Richardson, S. (2003). Earnings quality and short sellers. Accounting Horizons, 17(Supplement), 49-61.

Richardson, S. A., Sloan, R. G., Soliman, M. T., \& Tuna, I. (2005). Accrual reliability, earnings persistence and stock prices. Journal of Accounting \& Economics, 39(3), 437-485.

Robb, W. G. S. (1998). The effect of analysts' forecasts on earnings management in financial institutions. The Journal of Financial Research, 21(3), 315-331.

Rosner, R. L. (2003). Earnings manipulation in failing firms. Contemporary Accounting Research, 20(2), 361-408.

Ross, S. A. (1973). The economic theory of agency: The principal's problem. American Economic Review, 63(2), 134-139.

Saleh, N. M., \& Ahmed, K. (2005). Earnings management of distressed firms during debt renegotiation. Accounting and Business Research, 35(1), 69-86.

Saleh, N. M., Iskandar, T. M., \& Rahmat, M. M. (2005). Earnings management and board characteristics: Evidence from Malaysia. Jurnal Pengurusan, 24(4), $77-103$.

Saleh, N. M., Iskandar, T. M., \& Rahmat, M. M. (2007). Audit committee characteristics and earnings management: Evidence from Malaysia. Asian Review of Accounting, 15(2), 147-163.

Saludo, R. (1999). Charting the way ahead. Asia Week, April 16.

Salvato, C., \& Moores, K. (2010). Research on accounting in family firms: Past accomplishments and future challenges. Family Business Review, 23(3), 193215.

Sánchez, C., Alemán, J., \& Martín, D. (2007). Family control and earnings quality. Revista de Contabilidad, 10(1), 11-32.

Saw-Imm, S., Ali, R., \& Pillay, S. (2006). Family ownership, premiums paid and performance: Evidence from corporate take-overs in Malaysia. Corporate Ownership \& Control, 4(2), 89-99.

Schipper, K., \& Vincent, L. (2003). Earnings quality. Accounting Horizons, 17(Supplement), 97-110.

Schulze, W. S., Lubatkin, M. H., \& Dino, R. N. (2003). Toward a theory of agency and altruism in family firms. Journal of Business Venturing, 18(4), 473-490. 
Schulze, W. S., Lubatkin, M. H., Dino, R. N., \& Buchholtz, A. K. (2001). Agency relationships in family firms: Theory and evidence. Organization Science, 12(2), 99-116.

Searle, P. (1999). The riddle of Malaysian capitalism: Rent-seekers or real capitalists? Honolulu: Asian Studies Association of Australia in association with Allen \& Unwin and University of Hawaii Press.

Securities Commission (2007). Malaysian Code on Corporate Governance (Revised). Kuala Lumpur: Securities Commission of Malaysia.

Sevin, S., \& Schroeder, R. (2005). Earnings management: Evidence from SFAS No. 142 reporting. Managerial Auditing Journal, 20(1), 47-54.

Shleifer, A., \& Vishny, R. W. (1986). Large shareholders and corporate control. The Journal of Political Economy, 94(3), 461-488.

Shleifer, A., \& Vishny, R. W. (1997). A survey of corporate governance. Journal of Finance, 52(2), 737-783.

Shuto, A. (2007). Executive compensation and earnings management: Empirical evidence from Japan. Journal of International Accounting, Auditing and Taxation, 16(1), 1-26.

Sieh, L. M. L. (1982). Ownership and Control of Malaysia Manufacturing Corporations. Kuala Lumpur: University of Malaya Cooperative Bookshop Publication.

Simon, H. A. (1993). Altruism and economics. American Economic Review, 83, 156161.

Siregar, S. V., \& Utama, S. (2008). Type of earnings management and the effect of ownership structure, firm size, and corporate-governance practices: Evidence from Indonesia. The International Journal of Accounting, 43(1), 1-27.

Sloan, R. G. (1996). Do stock prices fully reflect information in accruals and cash flows about future earnings? The Accounting Review, 71(3), 289-315.

Smith Committee (2003). Audit Committees Combined Code Guidance: A report and proposed guidance by the FRC-appointed group. London: FRC.

Song, J., \& Windram, B. (2004). Benchmarking audit committee effectiveness in financial reporting. International Journal of Auditing, 8(3), 195-205.

Sraa, B., Kaur, G., Sze, J., Chong, Y., Chik, A. R., Chen, H., \& Keong, S. (2011). 40 Richest Malaysians. Malaysian Business, February 16, 24. 
Stark, O., \& Falk, I. (1998). Transfers, empathy formation, and reverse transfers. American Economic Review, 88(2), 271-276.

Stein, J. C. (1989). Efficient capital markets, inefficient firms: A model of myopic corporate behavior. Quarterly Journal of Economics, 104(4), 655-669.

Steven, B. (1998). Discretionary accounting choices and CEO compensation. Contemporary Accounting Research, 15(3), 229-252.

Suehiro, A., \& Wailerdsak, N. (2004). Family business in Thailand: Its management, governance and future challenges. ASEAN Economic Bulletin, 21(1), 81-93.

Summers, S. L., \& Sweeney, J. T. (1998). Fraudulently misstated financial statements and insider trading: An empirical analysis. The Accounting Review, 73(1), 131-146.

Suto, M. (2003). Capital structure and investment behaviour of Malaysian firms in the 1990s: A study of corporate governance before the crisis. Corporate Governance: An International Review, 11(2), 25-39.

Sweeney, A. P. (1994). Debt-covenant violations and managers' accounting responses. Journal of Accounting \& Economics, 17(3), 281-308.

Tam, O. K., \& Tan, M. G.-S. (2007). Ownership, governance and firm performance in Malaysia. Corporate Governance: An International Review, 15(2), 208222.

Tàpies, J., \& Fernandez, M. (2010). Values and longevity in family businesses: Evidence from a cross-cultural analysis. IEIE Business School, University of Navarra.

Teitel, K., \& Machuga, S. (2010). The interaction of audit firm quality and the Mexican code of best corporate practices on earnings quality. Review of Business Research, 10(3), 32-40.

Teoh, S. H., Welch, I., \& Wong, T. J. (1998). Earnings management and the underperformance of seasoned equity offerings. Journal of Financial Economics, 50(1), 63-99.

Teshima, N., \& Shuto, A. (2008). Managerial ownership and earnings management: Theory and empirical evidence from Japan. Journal of International Financial Management \& Accounting, 19(2), 107-132.

The World Bank (1998). East Asia: The Road to Recovery. Washington D.C.

The World Bank (2005). Corporate Governance Country Assessment: Malaysia June 2005. Report on the Observance of Standards and Code (ROSC) Corporate Governance. 
The World Bank (2009). Malaysia: Productivity and investment climate assessment update. Washington D.C.

Thillainathan, R. (1998). A review of corporate governance in Malaysia with special reference to shareholder and creditor rights. Malaysian Journal of Economic Studies, 35(1/2), 161-198.

Thomas, T. (2002). Corporate governane and debt in the Malaysian financial crisis of 1997 Corporate governance in Asia: Lessons from the financial crisis United Nations Devlopment Programme (UNDC).

Torii, T. (1997). The New Economic Policy and the United Malays National Organization: With special reference to the restructuring of Malaysian society. The Developing Economies, 35(3), 209-239.

Tricker, R. I. (1994). International Corporate Governance. Singapore: Simon \& Schuster.

Vafeas, N. (2000). Board structure and the informativeness of earnings. Journal of Accounting and Public Policy, 19(2), 139-160.

Vafeas, N. (2005). Audit committees, boards, and the quality of reported earnings. Contemporary Accounting Research, 22(4), 1093-1122.

Van der Meulen, S., Gaeremynck, A., \& Willekens, M. (2007). Attribute differences between U.S. GAAP and IFRS earnings: An Exploratory Study. The International Journal of Accounting, 42, 123-142.

Van Tendeloo, B., \& Vanstraelen, A. (2005). Earnings management under German GAAP versus IFRS. European Accounting Review, 14(1), 155-180.

Vander Bauwhede, H. (2001). Earnings management in a non-Anglo-Saxon environment: the impact of audit quality, public ownership and stakeholders. Unpublished Ph.D., Catholic University Leuven, Leuven, Belgium.

Vander Bauwhede, H., Willekens, M., \& Gaeremynck, A. (2003). Audit firm size, public ownership, and firms' discretionary accruals management. The International Journal of Accounting, 38(1), 1-22.

Velury, U., \& Jenkins, D. S. (2006). Institutional ownership and the quality of earnings. Journal of Business Research, 59(9), 1043-1051.

Villalonga, B., \& Amit, R. (2006). How do family ownership, control and management affect firm value? Journal of Financial Economics, 80(2), 385417.

Villalonga, B., \& Amit, R. (2010). Family control of firms and industries. Financial Management, Autumn, 863-904. 
Wan-Hussin, W. N. (2009). The impact of family-firm structure and board composition on corporate transparency: Evidence based on segment disclosures in Malaysia. The International Journal of Accounting, 44(4), 313333.

Wang, D. (2006). Founding family ownership and earnings quality. Journal of Accounting Research, 44(3), 619-656.

Warfield, T. D., Wild, J. J., \& Wild, K. L. (1995). Managerial ownership, accounting choices, and informativeness of earnings. Journal of Accounting \& Economics, 20(1), 61-91.

Watts, R. L., \& Zimmerman, J. L. (1978). Towards a positive theory of the determination of accounting standards. Accounting Review, 53(1), 112-134.

Welker, M. (1995). Disclosure policy, information asymmetry, and liquid in equity market. Contemporary Accounting Research, 11(2), 801-827.

White, H. (1980). A heteroskedasticity-consistent covariance matrix estimator and a direct test for heteroskedasticity. Econometrica, 48(4), 817-838.

Whittred, G., \& Chan, Y. K. (1992). Asset revaluations and the mitigation of underinvestment. Abacus, 28(1), 58-74.

Wild, J. J. (1996). The audit committee and earnings quality. Journal of Accounting, Auditing \& Finance, 11(2), 247-276.

Williams, L. K. (2007). How culture evolves: An institution analysis. International Journal of Social Economics, 34(4), 249-267.

Xie, B., Davidson, W. N., \& DaDalt, P. J. (2003). Earnings management and corporate governance: The role of the board and the audit committee. Journal of Corporate Finance, 9(3), 295-316.

Yang, J. S., \& Krishnan, J. (2005). Audit committees and quarterly earnings management. International Journal of Auditing, 9(3), 201-219.

Yang, M.-L. (2010). The impact of controlling families and family CEOs on earnings management Family Business Review, 23(3), 266-279.

Yatim, P., Kent, P., \& Clarkson, P. (2006). Governance structures, ethnicity, and audit fees of Malaysian listed firms. Managerial Auditing Journal, 21(7), $757-782$.

Yee, K. K. (2006). Earnings quality and the equity risk premium: A benchmark model. Contemporary Accounting Research, 23(3), 833-877. 
Yermack, D. (1996). Higher market valuation of companies with a small board of directors. Journal of Financial Economics, 40(2), 185-211.

Yeung, H. W.-C., \& Soh, T. M. (2000). Corporate governance and the global reach of Chinese family firms in Singapore. Seoul Journal of Economics, 13(3), 310334.

Young, D., \& Guenther, D. A. (2003). Financial reporting environments and international capital mobility. Journal of Accounting Research, 41(3), 553579 .

Zahra, S. A., \& Pearce II, J. A. (1989). Boards of directors and corporate financial performance: A review and integrative model. Journal of Management, 15(2), 291-334.

Zapalska, A. M., \& Edwards, W. (2001). Chinese entrepreneurship in a cultural and economic perspective. Journal of Small Business Management, 39(3), 286292.

Zhang, Y., Zhou, J., \& Zhou, N. (2007). Audit committee quality, auditor independence, and internal control weaknesses. Journal of Accounting and Public Policy, 26(3), 300-327.

Zhao, R., \& Millet-Reyes, B. (2007). Ownership structure and accounting information content: Evidence from France. Journal of International Financial Management \& Accounting, 18(3), 223-246.

Zheng, L. (2003). Did the 1998 Chinese accounting system improve earnings quality? Unpublished Ph.D., The University of Alabama, Alabama, United States.

Zhuang, J. (1999). Corporate Governance in East Asia: Some Policy Implications: Economic and Development Resource Center, Asian Development Banks. 


\section{Appendix 1: Compliance with OECD Corporate Governance Principles ${ }^{27}$}

\begin{tabular}{|c|c|c|}
\hline OECD Principles & Compliance & Details \\
\hline \multicolumn{3}{|l|}{ Section I: The Rights of Shareholders } \\
\hline Basic shareholders rights & Yes & $\begin{array}{l}\text { Companies Act confers all basic rights to shareholders, including secure methods } \\
\text { of ownership registration, free transfer of shares, the right to access information, } \\
\text { the right to participate and vote at AGM (except for non-voting preference share), } \\
\text { election of board and share in the profit. }\end{array}$ \\
\hline $\begin{array}{l}\text { The right to participate in decisions of fundamental } \\
\text { corporate changes }\end{array}$ & Yes & $\begin{array}{l}\text { Shareholders have the right to participate on the decisions relating to the } \\
\text { amendments to the statutes, authorizations of additional shares and extraordinary } \\
\text { transactions (resulting in sale of the company). }\end{array}$ \\
\hline $\begin{array}{l}\text { The right to be adequately informed about, participate } \\
\text { and vote in general shareholder meetings (AGM) }\end{array}$ & Some & $\begin{array}{l}\text { Shareholders are given sufficient and timely information about AGM. } \\
\text { Shareholders can participate and vote in company meetings and shareholder } \\
\text { ballots. A shareholder may appoint a proxy, who has the right to speak at a } \\
\text { meeting and may demand a poll. However, postal voting is not allowed. }\end{array}$ \\
\hline $\begin{array}{l}\text { Disclosure of capital structures and arrangements } \\
\text { enabling control disproportionate to equity ownership }\end{array}$ & Some & $\begin{array}{l}\text { Nominee accounts are common in Malaysia. However, beneficial owners are } \\
\text { required to reveal their identity. Some companies have special shares (golden } \\
\text { shares), which requires the holders' concern over certain matters, or confer rights } \\
\text { over the appointment of directors. Ownership concentration, pyramid structures } \\
\text { and cross-holdings are common and ownership structures are difficult to capture. }\end{array}$ \\
\hline $\begin{array}{l}\text { Efficient and transparent functioning of market for } \\
\text { corporate control }\end{array}$ & Some & $\begin{array}{l}\text { The market has clearly articulated and disclosed rules and procedure, transparent } \\
\text { prices and fair conditions. However, concentration of shareholding imposes a } \\
\text { constraint on the market for corporate control. }\end{array}$ \\
\hline \multicolumn{3}{|l|}{ Section II: Equitable Treatment of Shareholders } \\
\hline Equal treatments of shareholders within same class & Yes & $\begin{array}{l}\text { Shareholders within the same class have equal voting rights. Shareholders have } \\
\text { the ability to obtain information about voting rights attached to all classes of } \\
\text { shares before acquisition. Changes in voting rights are subject to shareholders } \\
\text { vote. }\end{array}$ \\
\hline Prohibition of insider trading and self-dealing & Yes & Shareholders have the right to call for an AGM, or can apply for a court order if \\
\hline
\end{tabular}

${ }^{27}$ The data is gathered from the World Bank report on corporate governance country assessment 2001 and 2005. 


\begin{tabular}{|c|c|c|}
\hline OECD Principles & Compliance & Details \\
\hline & & $\begin{array}{l}\text { they believe they have been oppressed, prejudiced, or unfairly discriminated } \\
\text { against or their interests disregarded. Section } 181 \text { of Companies Act covers the } \\
\text { situations where the shareholder alleges there has been appropriation of business, } \\
\text { property, or corporate opportunity at the expense of the company or its minority } \\
\text { shareholders, unjustifiable failure to pay dividends, or the director's neglect of the } \\
\text { duty of care, skill, and diligence. }\end{array}$ \\
\hline $\begin{array}{l}\text { Disclosure by directors and managers of material } \\
\text { interests in transactions and matters affecting the } \\
\text { company. }\end{array}$ & Yes & $\begin{array}{l}\text { KLSE's listing rules specify that a company must make a public announcement, } \\
\text { send a circular and seek the approval of shareholders on all material related party } \\
\text { transactions. Additionally, Malaysia has adopted IAS } 24 \text { on related party } \\
\text { disclosures. }\end{array}$ \\
\hline \multicolumn{3}{|l|}{$\begin{array}{l}\text { Section III: Role of Stakeholders in Corporate } \\
\text { Governance }\end{array}$} \\
\hline Respect of legal stakeholders rights & Yes & $\begin{array}{l}\text { The interests of stakeholders are included in the corporate governance framework } \\
\text { in Malaysia and proposals have been made to permit more active participation by } \\
\text { the other stakeholders, particularly the creditor banks and employees, in } \\
\text { enhancing corporate governance. The rights of the stakeholders are also } \\
\text { established under various statutes in the country such as the Labor Law, Contracts } \\
\text { Law, and Insolvency Law. }\end{array}$ \\
\hline $\begin{array}{l}\text { Performance enhancing mechanism for stakeholder } \\
\text { participation }\end{array}$ & Yes & $\begin{array}{l}\text { The law permit performance-enhancing mechanisms such as share option schemes } \\
\text { for employee participation to be developed. Employee Stock Option Scheme } \\
\text { (ESOS) is relatively common among Malaysian companies. Bursa Malaysia } \\
\text { regulates the ESOS size, recipients, and eligibility under the scheme. }\end{array}$ \\
\hline Access to relevant information & Yes & $\begin{array}{l}\text { Stakeholders have access to relevant, sufficient and reliable information on a } \\
\text { timely and regular basis when participating in the corporate governance process. } \\
\text { Firms' financial information, economic prospects and significant facts about } \\
\text { employees are required to be disclosed in the annual reports. As demanded by the } \\
\text { market regulator through its Listing requirements, the information in firms' } \\
\text { annual reports is sufficient, reliable and timely. }\end{array}$ \\
\hline $\begin{array}{l}\text { Concerns about any illegal or unethical practice could } \\
\text { be communicated to the board }\end{array}$ & Yes & $\begin{array}{l}\text { There is a legislation to protect whistleblowers such as directors, management, } \\
\text { and auditors, who report breaches of securities laws or listing rules and any matter } \\
\text { that had material and adverse financial impact on publicly listed companies. The } \\
\text { whistle-blowing provisions to report such breaches or financial matters were } \\
\text { mandatory for auditors. The legislation is effective from January } 2004 \text {. }\end{array}$ \\
\hline Existence of effective and efficient insolvency & Some & Due to some provisions under the Companies Act that deals with firms ongoing \\
\hline
\end{tabular}




\begin{tabular}{|c|c|c|}
\hline OECD Principles & Compliance & Details \\
\hline $\begin{array}{l}\text { framework and effective enforcement of creditor } \\
\text { rights. }\end{array}$ & & $\begin{array}{l}\text { concerns, the high court can issue summary orders temporarily restraining } \\
\text { creditors from proceeding against the company. The court can also permit an } \\
\text { arrangement or compromise between a company and its creditors, subject to } \\
\text { certain requirements. The act does not have a well-defined scheme of judicial } \\
\text { management of corporate restructuring. However, the country has established an } \\
\text { asset management company (Danaharta) to acquire non-performing loans from } \\
\text { banks, and assets from distressed companies, to minimize the problem of a credit } \\
\text { crunch and to facilitate an orderly payment/write-down of debts. For corporate } \\
\text { borrowers with total outstanding debt of less than RM } 50 \text { million, the Bank } \\
\text { Negara Malaysia provides assistance in enabling these borrowers to receive } \\
\text { financial support while restructuring their operations. Alternatively, the borrowers } \\
\text { could also use the Danaharta assistance. In Malaysia, the widespread practice of } \\
\text { pyramiding and cross-holdings causes a major divergence between the control and } \\
\text { cash flow rights of insiders. These insiders have the incentive to maximize their } \\
\text { private benefits of control and not necessarily shareholder value. Therefore, there } \\
\text { is a high risks for the interests of minority shareholders being expropriated or their } \\
\text { assets squandered. }\end{array}$ \\
\hline \multicolumn{3}{|l|}{ Section IV: Disclosure and Transparency } \\
\hline $\begin{array}{l}\text { Disclosure of material financial and non-financial } \\
\text { information }\end{array}$ & Yes & $\begin{array}{l}\text { Under legislative rules and listing requirements in Malaysia, firms are required to } \\
\text { disclose financial and operating results, company's objectives, major share } \\
\text { ownership and voting rights, remuneration policy for board and key executives, } \\
\text { information about directors, related party transactions, foreseeable risk factors, } \\
\text { issues regarding employees and other stakeholders, and governance structures and } \\
\text { policies in the annual reports. }\end{array}$ \\
\hline $\begin{array}{l}\text { Standards of accounting, disclosure, } \\
\text { and audit }\end{array}$ & Yes & $\begin{array}{l}\text { Malaysia has adopted IFRS, which is renamed as Financial Reporting Standards } \\
\text { beginning from } 2006 \text {. The law provides that it is the responsibility of the listed } \\
\text { corporation, its directors and chief executive to ensure the compliance with } \\
\text { accounting standards issued by the standards setting body, MASB. }\end{array}$ \\
\hline Annual audit by independent auditor & Yes & $\begin{array}{l}\text { The Listing Requirements requires a listed company to appoint an accounting firm } \\
\text { to act as its external auditors. The auditors have to comply with approved } \\
\text { standards on auditing, which are basically consistent with the International } \\
\text { Standards on Auditing issued by the International Auditing and Assurance } \\
\text { Standards Board of IFAC. External auditors also have to comply with the Code of } \\
\text { Ethics for Professional Accountants issued by IFAC and adopted by MIA that }\end{array}$ \\
\hline
\end{tabular}




\begin{tabular}{|c|c|c|}
\hline OECD Principles & Compliance & Details \\
\hline & & $\begin{array}{l}\text { require auditors to be independent, competent, and qualified to provide objective } \\
\text { assurance to the board and shareholders that the financial statements fairly } \\
\text { represent the performance of the company. }\end{array}$ \\
\hline Accountability of external auditors & Yes & $\begin{array}{l}\text { External auditors are required by the Companies Act to report to the shareholders } \\
\text { on the company's accounts, other records relating to the accounts, and } \\
\text { consolidated accounts (for holding company) before the company in general } \\
\text { meeting. In case of wrongdoings, the external auditors can be sued by the } \\
\text { company's shareholders or stakeholders. There is a mandatory requirement for } \\
\text { each auditor in Malaysia to obtain professional indemnity insurance for a } \\
\text { minimum coverage of RM 100,000.00. The audit committee, comprising a } \\
\text { majority of independent non-executive directors, oversees the audit function, and } \\
\text { the Bursa and the SC conduct reviews of the audited financial statements. Any } \\
\text { offense would result in sanctions against the publicly listed company and/or } \\
\text { directors, whereas the respective auditors are referred to the Malaysian Institute of } \\
\text { Accountants for disciplinary action. }\end{array}$ \\
\hline $\begin{array}{l}\text { Channels for disseminating } \\
\text { information }\end{array}$ & Yes & $\begin{array}{l}\text { Companies are required to make immediate public disclosure of all material } \\
\text { information concerning their affairs to the Bursa and SC. Access to corporate } \\
\text { information by the public is available through several channels, including annual } \\
\text { reports and annual audited accounts, quarterly financial reports, and notices and } \\
\text { circulars. Annual reports and the annual audited accounts are required to be } \\
\text { distributed directly to shareholders no less than } 14 \text { days before the AGM and are } \\
\text { also submitted to the Bursa. Quarterly financial reports are to be released not later } \\
\text { than } 2 \text { months after the end of each quarter of the company's financial year. } \\
\text { Access to such information also has been enhanced by the use of electronic } \\
\text { reporting and the internet as a channel for dissemination. }\end{array}$ \\
\hline \multicolumn{3}{|l|}{ Section V: Responsibilities of the Board } \\
\hline Duties and liabilities of the board & Some & $\begin{array}{l}\text { Directors do not owe their duties to the shareholders, but the company. Directors } \\
\text { have "trustee-like" fiduciary duties in addition to the duty of care, skill and } \\
\text { diligence. The board decides major policies and may appoint one of their own as } \\
\text { manager. There is no statutory or judicial recognition of the board's collective } \\
\text { duty to oversee management. The Bursa can take action against directors directly } \\
\text { involved with its listing rules and the SC can apply to court for disqualification of } \\
\text { directors where they have been convicted of offences or breach of rules. }\end{array}$ \\
\hline Fair treatment of each class of shareholders & Some & Companies Act tries to address the problem of controlling shareholders acting as \\
\hline
\end{tabular}




\begin{tabular}{|c|c|c|}
\hline OECD Principles & Compliance & Details \\
\hline & & $\begin{array}{l}\text { "shadow directors" by exercising control over board without taking on the } \\
\text { corresponding statutory duties and liabilities. }\end{array}$ \\
\hline $\begin{array}{l}\text { Applying high ethical standards and taking into } \\
\text { account stakeholders interests. }\end{array}$ & Some & $\begin{array}{l}\text { There are voluntary code of ethics such as Rukuniaga Malaysia (Malaysian Code } \\
\text { of Business Ethics) and the Directors' Code of Ethics. }\end{array}$ \\
\hline Fulfilling boards key function & Some & $\begin{array}{l}\text { The board is responsible for the overall corporate governance of the company } \\
\text { including its strategic direction, establishing goals for management, and } \\
\text { monitoring the achievement of those goals. The role and function of the board are } \\
\text { usually documented in a board charter. The Audit Committee, Investment } \\
\text { Committee, and Executive Committee play a important role in channeling } \\
\text { important operational and assurance-related issues to the board. In practice, } \\
\text { almost all Malaysian companies have established an Audit Committee to } \\
\text { independently monitor its financial reporting and compliance with laws and } \\
\text { regulations. However, the establishment of the other board committees such as } \\
\text { remuneration, nomination and executive is left to the individual companies, as the } \\
\text { level of monitoring differs from one company to another. }\end{array}$ \\
\hline Directors objectivity and commitment & Yes & $\begin{array}{l}\text { The Listing Requirements stipulate that at least two directors, or one third of the } \\
\text { board, whichever is higher, must be independent directors. Audit Committee is } \\
\text { required under the Listing Requirements and should comprise at least three } \\
\text { members, with a majority of independent members. At least one member of the } \\
\text { committee must be financially trained or a qualified accountant. The Listing } \\
\text { Requirements indirectly state that board has to meet at least four times a year. The } \\
\text { MCCG and the listing rules require disclosure in the annual report of the number } \\
\text { of board meetings held in a year and the details of attendance of each individual } \\
\text { director. A director is automatically disqualified if (s)he is absent from more than } \\
50 \text { percent of the total board meetings held in a year. Directors are not allowed to } \\
\text { hold directorships in more than } 25 \text { companies, specifically in } 10 \text { listed companies } \\
\text { and } 15 \text { unlisted companies. }\end{array}$ \\
\hline
\end{tabular}




\section{Appendix 2: Definition of Family Firm in Previous Studies}

\begin{tabular}{|c|c|c|}
\hline Author(s) & Sample & Definition of Family Firms \\
\hline $\begin{array}{l}\text { Arosa ,Iturralde, and } \\
\text { Maseda (2010) }\end{array}$ & Spain, 2006 & $\begin{array}{l}\text { A family firm is a firm that has a large body of common stock held by the founder or family } \\
\text { members, allowing them to exercise control over the firm, and also family members who } \\
\text { participate actively in monitoring the firm. }\end{array}$ \\
\hline Chau and Gray (2010) & Hong Kong, 2002 & $\begin{array}{l}\text { Family firms are identified based on the percentage of common shares held by founding families } \\
\text { and their relatives. }\end{array}$ \\
\hline Jiraporn and Dadalt (2009) & U.S., 1994-1999 & $\begin{array}{l}\text { Family firms are identified based on the fractional equity ownership of the founding family } \\
\text { and/or the presence of family members serving on the board of directors. }\end{array}$ \\
\hline Andres (2008) & Germany, 1998 to 2004 & $\begin{array}{l}\text { Family firm is firm that has a founder and/or family members (1) with more than } 25 \% \text { of the } \\
\text { voting shares, and/or (2) represented on either the executive or the supervisory board. }\end{array}$ \\
\hline $\begin{array}{l}\text { Prencipe, Markarian, and } \\
\text { Pozza (2008) }\end{array}$ & Italy, 2003 & $\begin{array}{l}\text { Family firms are defined as firms in which one or more families linked by kinship, close affinity, } \\
\text { or solid alliances hold a sufficiently large share of capital to enable them to make decisions } \\
\text { regarding strategic management. }\end{array}$ \\
\hline $\begin{array}{l}\text { Ali, Chen and } \\
\text { Radhakrishnan (2007) }\end{array}$ & U.S., 2002 & $\begin{array}{l}\text { Family firm is a firm whose founders or descendants continue to hold positions in the top } \\
\text { management or on the board, or are among the company's largest shareholders. }\end{array}$ \\
\hline $\begin{array}{l}\text { Sánchez, Alemán and } \\
\text { Martín (2007) }\end{array}$ & Spain, 1997-2003 & $\begin{array}{l}\text { A firm, in which the ultimate owner is a family, and the family is represented on the board. } \\
\text { Ultimate owner is the principal shareholder, who directly or indirectly owns a percentage of } \\
\text { voting rights that is equal to or above an established level of control }(10 \%) \text {. }\end{array}$ \\
\hline Kim (2006) & Korea,1991 to 1998 & $\begin{array}{l}\text { Family firms are "chaebols" firms, defined based on business groups designation provided by the } \\
\text { Korean Fair Trade Commission as "Daegyumo Guiup Jipdan" (which is literally translated as } \\
\text { "big business groups"). }\end{array}$ \\
\hline Maury (2006) & $\begin{array}{l}13 \text { Western European } \\
\text { countries, } 1996 \text { to } 2003\end{array}$ & $\begin{array}{l}\text { Family firm are firms with a family, an individual, or an unlisted firm as largest shareholders, } \\
\text { which hold at least } 10 \% \text { of the voting rights. }\end{array}$ \\
\hline Villalonga and Amit (2006) & U.S., 1994 to 2000 & $\begin{array}{l}\text { Family firms are those in which the founder or a member of his or her family by either blood or } \\
\text { marriage is an officer, director, or block holder, either individually or as a group. }\end{array}$ \\
\hline
\end{tabular}




\begin{tabular}{|c|c|c|}
\hline Wang (2006) & U.S., 1994-2002 & $\begin{array}{l}\text { Firms with substantial common stock held by family members or with founding family members } \\
\text { actively involved in the management or the board of directors. }\end{array}$ \\
\hline $\begin{array}{l}\text { Barth, Gulbrandsen and } \\
\text { Schøne (2005) }\end{array}$ & Norway, 1996 & $\begin{array}{l}\text { Family-owned firms are firms with an individual or a family owning at least 33\% of firms } \\
\text { shares. }\end{array}$ \\
\hline Anderson and Reeb (2004) & U.S., 1992 to 1999 & $\begin{array}{l}\text { Family firms are publicly traded firms, in which the founding families continue to have an } \\
\text { ownership stakes or maintain board seats. Alternative measurement of family firm is (1) the ratio } \\
\text { of board seats held by family members to board seats held by independent directors, and (2) a } \\
\text { dummy variable taking the value } 1 \text { if family board control exceeds independent board control, } \\
\text { otherwise } 0 \text {. }\end{array}$ \\
\hline $\begin{array}{l}\text { Suehiro and Wailerdsak } \\
\text { (2004) }\end{array}$ & $\begin{array}{l}\text { Thailand, } 1996 \text { and } \\
2000\end{array}$ & $\begin{array}{l}\text { Family business is defined as a firm or a group which meets three major conditions: (1) owner } \\
\text { family members control its ownership through various means; (2) they exert control over its top } \\
\text { management; and (3) owner family members have succeeded, otherwise will intend to succeed, } \\
\text { the business of their founder. }\end{array}$ \\
\hline Anderson and Reeb (2003a) & U.S., 1992 to 1999 & $\begin{array}{l}\text { Family firm is based on fractional equity ownership of the founding family and / or the presence } \\
\text { of family members serving on the board of directors. Other definitions employed: Ratio of board } \\
\text { seats held by family members to board seats held by independent directors / CEO founder } \\
\text { indicates a founding family firm when the CEO is the founder of the firm / CEO descendent } \\
\text { indicates a founding family firm when the CEO is a descendent of the founder during the past } \\
\text { decade. }\end{array}$ \\
\hline Anderson and Reeb (2003b) & U.S., 1993 to 1999 & A firm is identified as family firm when founding family has an equity stake in firm equity. \\
\hline $\begin{array}{l}\text { Schulze, Lubatkin and Dino } \\
\text { (2003) }\end{array}$ & U.S., 1995 & $\begin{array}{l}\text { Family firms are privately held, have greater than } \$ 5 \mathrm{~m} \text { annual sales, and listed by Arthur } \\
\text { Anderson as a family business. }\end{array}$ \\
\hline $\begin{array}{l}\text { Claessens, Djankov, Fan } \\
\text { and Lang (2002) }\end{array}$ & $\begin{array}{l}8 \text { East Asian } \\
\text { countries, } 1996\end{array}$ & $\begin{array}{l}\text { Family firm are firms in which there is a presence of a group of people related by blood or } \\
\text { marriage with large ownership stakes. }\end{array}$ \\
\hline Faccio and Lang (2002) & $\begin{array}{l}13 \text { Western European } \\
\text { countries, } 1996 \text { to } 1999\end{array}$ & $\begin{array}{l}\text { Firms are considered as family firms when a family or an individual or unlisted firm hold greater } \\
\text { than } 20 \% \text { of either cash flow or control rights. }\end{array}$ \\
\hline $\begin{array}{l}\text { Schulze, Lubatkin, Dino and } \\
\text { Buchholtz (2001) }\end{array}$ & U.S., 1995 & $\begin{array}{l}\text { Family firms are privately held, have greater than } \$ 5 \mathrm{~m} \text { annual sales, and listed by Arthur } \\
\text { Anderson as a family business. }\end{array}$ \\
\hline $\begin{array}{l}\text { Claessens, Djankov and } \\
\text { Lang (2000) }\end{array}$ & $\begin{array}{l}9 \text { East Asian countries, } \\
1996\end{array}$ & $\begin{array}{l}\text { Family firms are firms with family groups, which control more than } 5 \% \text { of the company's votes. } \\
\text { Family group is identified through published family trees in each country and may consist of one }\end{array}$ \\
\hline
\end{tabular}




\begin{tabular}{|l|l|l|}
\hline & & family or a group of families. \\
\hline $\begin{array}{l}\text { La Porta, Lopez-de-Salines } \\
\text { and Shleifer (1999) }\end{array}$ & $\begin{array}{l}27 \text { richest countries, } \\
1995 \text { to } 1997\end{array}$ & $\begin{array}{l}\text { Firms are considered as family firms when the controlling shareholder (the ultimate owner) is an } \\
\text { individual or a family, based on 10\% and 20\% direct and indirect voting rights cut-offs. }\end{array}$ \\
\hline $\begin{array}{l}\text { McConaughy, Walker, } \\
\text { Handerson and Mishra } \\
(1998)\end{array}$ & U.S., 1987 & $\begin{array}{l}\text { Family founder controlled firm is a publicly listed firm whose CEO is either the founder or a } \\
\text { member of the founder's family. }\end{array}$ \\
\hline $\begin{array}{l}\text { Morck, Shleifer and Vishny } \\
(1988)\end{array}$ & U.S., 1980 & Family firm is firm with a member of the founding family being among the top two officers. \\
\hline Allen and Panian (1982) & U.S., 1971 to 1980 & $\begin{array}{l}\text { Family firms are firms, in which the members of a descendent group and their affines owned or } \\
\text { controlled at least 5 percent of the voting stock and are represented on board of directors. Family } \\
\text { firms are further classified into firms with direct family control and indirect family control. } \\
\text { Family firms that have a CEO, who is also a member of the controlling family are classified as } \\
\text { having direct family control. }\end{array}$ \\
\hline James and Soref (1981) & U.S. 1965 & $\begin{array}{l}\text { Family controlled firms are firms with major shareholders represented on the board (using a } \\
\text { dichotomous variable). }\end{array}$ \\
\hline
\end{tabular}




\section{Appendix 3: Empirical Studies on Firms Ownership and Accounting Quality}

\begin{tabular}{|c|c|c|c|c|c|}
\hline Author(s) & Research objective & Sample & $\begin{array}{l}\text { Measures for } \\
\text { Accounting Quality }\end{array}$ & $\begin{array}{l}\text { Measures for Ownership } \\
\text { Variables }\end{array}$ & Results \\
\hline $\begin{array}{l}\text { Cascino, } \\
\text { Pugliese, } \\
\text { Mussolino and } \\
\text { Sansone } \\
(2010)\end{array}$ & $\begin{array}{l}\text { To explore the quality of } \\
\text { accounting information in } \\
\text { listed family firms. }\end{array}$ & $\begin{array}{l}778 \text { firm-year } \\
\text { observations } \\
\text { of listed Italian } \\
\text { firms over } \\
1998-2004 .\end{array}$ & $\begin{array}{l}\text { Accrual quality, } \\
\text { persistence, } \\
\text { predictability, } \\
\text { smoothness, value } \\
\text { relevance, timeliness } \\
\text { and conservatism. }\end{array}$ & $\begin{array}{l}\text { Family firms are firms in which } \\
50 \% \text { of voting rights or } \\
\text { outstanding shares (both direct } \\
\text { and indirect) are held by family } \\
\text { blockholders, and with at least } \\
\text { one family member holding a } \\
\text { managerial position. }\end{array}$ & $\begin{array}{l}\text { Family firms have higher } \\
\text { accrual quality, less } \\
\text { persistence, more predictable, } \\
\text { smoother, more value-relevant } \\
\text { and timely earnings relative to } \\
\text { nonfamily firms. }\end{array}$ \\
\hline $\begin{array}{l}\text { Chau and Gray } \\
\text { (2010) }\end{array}$ & $\begin{array}{l}\text { To examine whether the } \\
\text { association between the } \\
\text { extent of voluntary } \\
\text { disclosure and the level of } \\
\text { family ownership is non- } \\
\text { monotonic. }\end{array}$ & $\begin{array}{l}273 \text { HK firms } \\
\text { listed on the } \\
\text { Main Board of } \\
\text { the HK Ex for } \\
\text { the year of } \\
2002 \text {. }\end{array}$ & $\begin{array}{l}\text { Voluntary disclosure } \\
\text { of strategic, financial } \\
\text { and non-financial } \\
\text { information. }\end{array}$ & $\begin{array}{l}\text { Family ownership is measured } \\
\text { as the percentage of common } \\
\text { shares held by the founding } \\
\text { family and their relatives. }\end{array}$ & $\begin{array}{l}\text { When the level of family } \\
\text { shareholding is less than } 25 \% \text {, } \\
\text { family shareholding is } \\
\text { associated with lower } \\
\text { voluntary disclosure } \\
\text { supporting convergence of } \\
\text { interest hypothesis. When the } \\
\text { interests converge, the need } \\
\text { for voluntary disclosure is } \\
\text { lower. However, when family } \\
\text { share is more than } 25 \% \text {, the } \\
\text { entrenchment effect dominates } \\
\text { and is associated with higher } \\
\text { voluntary disclosure. }\end{array}$ \\
\hline Klai (2010) & $\begin{array}{l}\text { To examine whether the } \\
\text { control by foreigners, block } \\
\text { holders, families and states } \\
\text { affects the quality of } \\
\text { financial reporting. }\end{array}$ & $\begin{array}{l}22 \\
\text { nonfinancial } \\
\text { firms listed on } \\
\text { Tunisian Stock } \\
\text { Exchange } \\
\text { during the } \\
\text { period 1997- } \\
2007 \text {. } \\
\end{array}$ & $\begin{array}{l}\text { Principal component } \\
\text { analysis (a single } \\
\text { measure) from two } \\
\text { earnings quality } \\
\text { measures, accrual } \\
\text { quality and earnings } \\
\text { informativeness. }\end{array}$ & $\begin{array}{l}\text { Family control is measured as } \\
\text { the percentage of directors who } \\
\text { represent families and their } \\
\text { shareholdings. }\end{array}$ & $\begin{array}{l}\text { The control by foreigners, } \\
\text { families and block holders } \\
\text { reduces reporting quality, } \\
\text { while the control by the state } \\
\text { and financial institutions is } \\
\text { associated with higher } \\
\text { reporting quality. }\end{array}$ \\
\hline
\end{tabular}




\begin{tabular}{|c|c|c|c|c|c|}
\hline $\begin{array}{l}\text { Givoly, Hayn } \\
\text { and Katz } \\
(2010)\end{array}$ & $\begin{array}{l}\text { To examine whether public } \\
\text { equity ownership improves } \\
\text { firms earnings quality. }\end{array}$ & $\begin{array}{l}12,261 \text { firm- } \\
\text { year } \\
\text { observations } \\
\text { from } 2817 \\
\text { firms, over } \\
1978-2003 \text {, } \\
\text { extracted from } \\
\text { Compustat. }\end{array}$ & $\begin{array}{l}\text { Accrual persistence, } \\
\text { accrual estimation } \\
\text { error (modified } \\
\text { Dechow and Dichev } \\
\text { model), absence of } \\
\text { earnings management } \\
\text { and conservatism. }\end{array}$ & $\begin{array}{l}\text { Firms considered as having } \\
\text { public equity ownership are } \\
\text { public companies that publicly } \\
\text { trade their equities. Private } \\
\text { equity companies are public } \\
\text { companies with privately held } \\
\text { equity, but publicly trade debt. }\end{array}$ & $\begin{array}{l}\text { Private equity firms are } \\
\text { associated with higher quality } \\
\text { accruals and a lower } \\
\text { propensity to manage income } \\
\text { compared to public equity } \\
\text { firms. }\end{array}$ \\
\hline Yang (2010) & $\begin{array}{l}\text { To examine the relationship } \\
\text { between insider ownership } \\
\text { and earnings management in } \\
\text { family firms and the impact } \\
\text { of family CEO on earnings } \\
\text { management. }\end{array}$ & $\begin{array}{l}3914 \text { firm-year } \\
\text { observations } \\
\text { of Taiwanese } \\
\text { listed firms, } \\
\text { over } 2001- \\
2008 .\end{array}$ & $\begin{array}{l}\text { Earnings } \\
\text { management } \\
\text { measured by Jones } \\
\text { (1991) discretionary } \\
\text { accrual model as } \\
\text { modified by Kothari } \\
\text { et al. (2005). }\end{array}$ & $\begin{array}{l}\text { Controlling families are families } \\
\text { that own more than } 20 \% \text { control } \\
\text { rights. Insider ownership is } \\
\text { measured based on (1) the } \\
\text { proportion of insider ownership } \\
\text { over total shares, }(2) \text { control } \\
\text { rights or voting rights ( } 3) \\
\text { entrenchment effect or the } \\
\text { degree of divergence. }\end{array}$ & $\begin{array}{l}\text { Family firms with higher level } \\
\text { of insider ownership are more } \\
\text { likely to have higher level of } \\
\text { earnings management. Family } \\
\text { CEO have lower tendency to } \\
\text { manage earnings compared to } \\
\text { nonfamily CEO. }\end{array}$ \\
\hline $\begin{array}{l}\text { Beuselinck, } \\
\text { Deloof and } \\
\text { Manigart } \\
\text { (2009) }\end{array}$ & $\begin{array}{l}\text { To study the association } \\
\text { between private equity } \\
\text { ownership and the earnings } \\
\text { quality. }\end{array}$ & $\begin{array}{l}488 \text { unlisted } \\
\text { Belgian firms } \\
\text { with private } \\
\text { equity. }\end{array}$ & $\begin{array}{l}\text { Conditional loss } \\
\text { recognition } \\
\text { timeliness (Ball and } \\
\text { Shivakumar } 2005 \\
\text { model) }\end{array}$ & $\begin{array}{l}\text { Private equity involvement is } \\
\text { measured based on the } \\
\text { proportion of private equity } \\
\text { ownership in the sample firms. }\end{array}$ & $\begin{array}{l}\text { The results show that (1) } \\
\text { private equity (PE) } \\
\text { involvement increases a firm's } \\
\text { willingness to recognize losses } \\
\text { more timely as compared to } \\
\text { industry, size and life-cycle } \\
\text { matched non-PE backed firms, } \\
\text { (2) the effect is more powerful } \\
\text { for firms backed by } \\
\text { independent and captive PE- } \\
\text { investors as compared to firms } \\
\text { backed by government-related } \\
\text { PE-investors, (3) there is no } \\
\text { systematic variation in } \\
\text { earnings quality across } \\
\text { different levels of PE } \\
\text { ownership. }\end{array}$ \\
\hline
\end{tabular}




\begin{tabular}{|c|c|c|c|c|c|}
\hline $\begin{array}{l}\text { Jaggi, Leung } \\
\text { and Gul } \\
(2009)\end{array}$ & $\begin{array}{l}\text { To examine whether the } \\
\text { monitoring effectiveness of } \\
\text { independent corporate } \\
\text { boards is affected by the } \\
\text { family ownership control or } \\
\text { the appointment of family } \\
\text { members on corporate } \\
\text { boards. }\end{array}$ & $\begin{array}{l}309 \text { Hong } \\
\text { Kong firms } \\
\text { over } 1998- \\
2000 .\end{array}$ & Accrual quality. & $\begin{array}{l}\text { Family-owned firms are } \\
\text { identified using share ownership } \\
\text { (of more than } 20 \% \text { ) and the } \\
\text { presence of } 2 \text { or more family on } \\
\text { the board. }\end{array}$ & $\begin{array}{l}\text { Monitoring effectiveness of } \\
\text { independent directors are } \\
\text { reduced in family-controlled } \\
\text { firms. }\end{array}$ \\
\hline $\begin{array}{l}\text { Jiraporn and } \\
\text { DaDalt (2009) }\end{array}$ & $\begin{array}{l}\text { To examine the relationship } \\
\text { between founding family } \\
\text { control and earnings } \\
\text { management. }\end{array}$ & $\begin{array}{l}805 \text { firm-year } \\
\text { observations } \\
\text { of S\&P } 500 \\
\text { over } 1994- \\
1999 .\end{array}$ & $\begin{array}{l}\text { Earnings } \\
\text { management is } \\
\text { calculated using the } \\
\text { modified Jones } \\
\text { (1991) model. }\end{array}$ & $\begin{array}{l}\text { Family-owned firms are } \\
\text { identified based on the } \\
\text { fractional equity ownership of } \\
\text { the founding family and/or the } \\
\text { presence of family members. A } \\
\text { binary variable is used to } \\
\text { designate family control. }\end{array}$ & $\begin{array}{l}\text { Family firms are less likely to } \\
\text { manage earnings. }\end{array}$ \\
\hline Katz (2009) & $\begin{array}{l}\text { To study how firms' } \\
\text { ownership structures (private } \\
\text { equity sponsorship), affect } \\
\text { firms' earnings quality and } \\
\text { long-term performance. }\end{array}$ & $\begin{array}{l}147 \text { IPOs } \\
(1,070 \text { firm- } \\
\text { year } \\
\text { observations }) \\
\text { over } 1980- \\
2005 .\end{array}$ & $\begin{array}{l}\text { Earnings } \\
\text { management } \\
\text { (modified Jones } \\
\text { model) and timely } \\
\text { loss recognition (Ball } \\
\text { and Shivakumar } \\
\text { model). }\end{array}$ & $\begin{array}{l}\text { Ownership structure examined } \\
\text { in this study is private equity } \\
\text { with majority holdings, private } \\
\text { equity with minority holdings, } \\
\text { and management ownership. }\end{array}$ & $\begin{array}{l}\text { Private equity backed firms } \\
\text { have higher earnings quality, } \\
\text { engage less in earnings } \\
\text { management, and report more } \\
\text { conservatively both before and } \\
\text { after the IPO. }\end{array}$ \\
\hline $\begin{array}{l}\text { Korczak and } \\
\text { Korczak } \\
(2009)\end{array}$ & $\begin{array}{l}\text { To test the association } \\
\text { between ownership structure } \\
\text { and the quality of accounting } \\
\text { information. }\end{array}$ & $\begin{array}{l}528 \text { frim-year } \\
\text { observation of } \\
172 \text { companies } \\
\text { over } 1999- \\
2002 \text { period. }\end{array}$ & $\begin{array}{l}\text { Informativeness of } \\
\text { earnings measured } \\
\text { based on returns- } \\
\text { earnings relationship. }\end{array}$ & $\begin{array}{l}\text { Managerial ownership is } \\
\text { measured as the percentage of } \\
\text { shares held by managers and } \\
\text { their family members. Unrelated } \\
\text { block ownership is the sum of } \\
\text { all shares more than 5\% other } \\
\text { than managerial ownership. } \\
\text { Unrelated block ownership is } \\
\text { then categorized as government, } \\
\text { foreign investors, institutions, } \\
\text { National Investment Funds or } \\
\text { unrelated individuals. }\end{array}$ & $\begin{array}{l}\text { Earnings informativeness } \\
\text { increases when few block } \\
\text { holders jointly hold between } \\
25-50 \% \text { of shares. Managerial } \\
\text { holdings have positive } \\
\text { association with the } \\
\text { information content of } \\
\text { earnings. }\end{array}$ \\
\hline
\end{tabular}




\begin{tabular}{|c|c|c|c|c|c|}
\hline Kwak (2009) & $\begin{array}{l}\text { To investigate the } \\
\text { association between } \\
\text { institutional ownership } \\
\text { structures and the quality of } \\
\text { earnings information }\end{array}$ & $\begin{array}{l}\text { Japanese firms } \\
\text { during 1990- } \\
1998 .\end{array}$ & $\begin{array}{l}\text { Earnings response } \\
\text { coefficients. }\end{array}$ & Institutional ownership. & $\begin{array}{l}\text { The greater the percentage of } \\
\text { institutional shareholders in } \\
\text { Japan, the better the quality of } \\
\text { earnings information and the } \\
\text { higher the foreign ownership. }\end{array}$ \\
\hline $\begin{array}{l}\text { Machuga and } \\
\text { Teitel (2009) }\end{array}$ & $\begin{array}{l}\text { To examine the association } \\
\text { between board } \\
\text { characteristics (board } \\
\text { composition disclosure, } \\
\text { family concentrated } \\
\text { ownership and shared- } \\
\text { directors) and earnings } \\
\text { quality. }\end{array}$ & $\begin{array}{l}62 \text { firms listed } \\
\text { on the } \\
\text { Mexican Stock } \\
\text { Exchange } \\
\text { (Bolsa) over } \\
\text { the period } \\
\text { 1998-2002. }\end{array}$ & $\begin{array}{l}\text { Income smoothing, } \\
\text { timely loss } \\
\text { recognition and } \\
\text { conditional accruals. }\end{array}$ & $\begin{array}{l}\text { Family concentrated ownership } \\
\text { is based on the ratio of the } \\
\text { independent non-related board } \\
\text { members to the total board. }\end{array}$ & $\begin{array}{l}\text { Firms that do not have } \\
\text { concentrated family ownership } \\
\text { or share directors are more } \\
\text { likely to have greater increases } \\
\text { in earnings quality. }\end{array}$ \\
\hline $\begin{array}{l}\text { Pergola, } \\
\text { Joseph and } \\
\text { Jenzarli (2009) }\end{array}$ & $\begin{array}{l}\text { To study the association } \\
\text { between board members } \\
\text { ownership and earnings } \\
\text { quality. }\end{array}$ & $\begin{array}{l}499 \text { publicly } \\
\text { traded firms } \\
\text { from the } S \& P \\
500 \text { (large } \\
\text { cap), S\&P } 400 \\
\text { (mid cap), and } \\
\text { S\&P } 600 \\
\text { (small cap) } \\
\text { indices, in } \\
2002 \text {. }\end{array}$ & $\begin{array}{l}\text { Earnings quality is } \\
\text { measured using } \\
\text { Dechow and Dichev } \\
\text { (2002) accrual } \\
\text { quality model. }\end{array}$ & $\begin{array}{l}\text { Board insiders ownership is the } \\
\text { percentage of shares owned by } \\
\text { insiders (executive directors) to } \\
\text { total board shares. }\end{array}$ & $\begin{array}{l}\text { Earnings quality is negatively } \\
\text { associated with insider } \\
\text { ownership and the association } \\
\text { is moderated by governance } \\
\text { structures. }\end{array}$ \\
\hline $\begin{array}{l}\text { Prencipe, } \\
\text { Markarian and } \\
\text { Pozza (2008) }\end{array}$ & $\begin{array}{l}\text { To study the motivations of } \\
\text { earnings management in } \\
\text { family and non-family firms. }\end{array}$ & $\begin{array}{l}182 \text { firms } \\
\text { listed on Milan } \\
\text { Stock } \\
\text { Exchange in } \\
\text { the year } 2003 .\end{array}$ & $\begin{array}{l}\text { Earnings } \\
\text { management is based } \\
\text { on the capitalization } \\
\text { of } R \& D \text { cost. }\end{array}$ & $\begin{array}{l}\text { Family firms are firms where } \\
\text { the dominant family owns } \\
\text { directly or indirectly more than } \\
50 \% \text { of equity, or the dominant } \\
\text { family controls the firm's } \\
\text { strategic decisions. }\end{array}$ & $\begin{array}{l}\text { Family firms are less likely to } \\
\text { manage earnings for income- } \\
\text { smoothing purposes, } \\
\text { compared to nonfamily firms. } \\
\text { However, both family and } \\
\text { nonfamily firms are similarly } \\
\text { motivated to manage earnings } \\
\text { to avoid debt-covenant } \\
\text { violations. }\end{array}$ \\
\hline $\begin{array}{l}\text { Siregar and } \\
\text { Utama (2008) }\end{array}$ & $\begin{array}{l}\text { To investigate whether } \\
\text { companies listed on the } \\
\text { Jakarta Stock Exchange }\end{array}$ & $\begin{array}{l}144 \text { firms } \\
\text { listed on the } \\
\text { Jakarta Stock }\end{array}$ & $\begin{array}{l}\text { Earnings } \\
\text { management is } \\
\text { measured as }\end{array}$ & $\begin{array}{l}\text { Family own firms are firms } \\
\text { whose listed ownership } \\
\text { excluding the state, financial }\end{array}$ & $\begin{array}{l}\text { Firms with higher proportion } \\
\text { of family ownership and non- } \\
\text { business groups are }\end{array}$ \\
\hline
\end{tabular}




\begin{tabular}{|c|c|c|c|c|c|}
\hline & $\begin{array}{l}\text { conduct efficient or } \\
\text { opportunistic earnings } \\
\text { management and to examine } \\
\text { the effect of ownership } \\
\text { structure, firm size, and } \\
\text { corporate-governance } \\
\text { practices on earnings } \\
\text { management. }\end{array}$ & $\begin{array}{l}\text { Exchange for } \\
\text { the years of } \\
1995 \text { to } 1996 \\
\text { and } 1999 \text { to } \\
2002 \text {. }\end{array}$ & $\begin{array}{l}\text { discretionary accrual } \\
\text { using Jones (1991), } \\
\text { Dechow, Sloan and } \\
\text { Sweeney (1995), } \\
\text { Kasznik(1999) and } \\
\text { Dechow Richardson } \\
\text { and Tuna (2002) } \\
\text { models. }\end{array}$ & $\begin{array}{l}\text { institutions, or the public is } \\
\text { more than } 5 \% \text {. Sample is then } \\
\text { divided into high and low } \\
\text { family ownership, based on } \\
50 \% \text { cut-off point. }\end{array}$ & $\begin{array}{l}\text { significantly more likely to } \\
\text { choose efficient earnings } \\
\text { management relative to other } \\
\text { firms. }\end{array}$ \\
\hline $\begin{array}{l}\text { Teshima and } \\
\text { Shuto (2008) }\end{array}$ & $\begin{array}{l}\text { To examine the relationship } \\
\text { between managerial } \\
\text { ownership and earnings } \\
\text { management. }\end{array}$ & $\begin{array}{l}18,163 \text { firm- } \\
\text { year } \\
\text { observations } \\
\text { of Japanese } \\
\text { firms over } \\
1991-2000 .\end{array}$ & $\begin{array}{l}\text { Earnings } \\
\text { management } \\
\text { measured based on } \\
\text { Jones (1991) } \\
\text { discretionary accrual } \\
\text { model as modified by } \\
\text { Kasnik (1999). } \\
\end{array}$ & $\begin{array}{l}\text { Managerial ownership is based } \\
\text { on the fraction of shares held by } \\
\text { all directors. }\end{array}$ & $\begin{array}{l}\text { The study found a significant } \\
\text { non-monotonic relationship } \\
\text { between managerial } \\
\text { ownership and discretionary } \\
\text { accruals in Japanese firms. }\end{array}$ \\
\hline $\begin{array}{l}\text { Ali, Chen and } \\
\text { Radhakrishnan } \\
\text { (Ali et al., } \\
\text { 2007) }\end{array}$ & $\begin{array}{l}\text { To examine the influence of } \\
\text { family firms on corporate } \\
\text { disclosure; in terms of } \\
\text { earnings quality, voluntary } \\
\text { disclosure of bad news } \\
\text { through management } \\
\text { earnings forecasts, and } \\
\text { voluntary disclosure of } \\
\text { corporate governance } \\
\text { practices. }\end{array}$ & $\begin{array}{l}\text { S\&P } 500 \text { firms } \\
\text { over } 1998- \\
2002 \text { period. }\end{array}$ & $\begin{array}{l}\text { Earnings quality is } \\
\text { based on the level of } \\
\text { discretionary accruals } \\
\text { in earnings, the } \\
\text { ability of earnings } \\
\text { components to } \\
\text { predict future cash } \\
\text { flows, the persistence } \\
\text { of earnings, and the } \\
\text { association of } \\
\text { earnings with } \\
\text { contemporaneous } \\
\text { stock returns. }\end{array}$ & $\begin{array}{l}\text { Family firms are firms that have } \\
\text { the founder and/or their } \\
\text { descendents holding the top } \\
\text { positions in managements or are } \\
\text { among companies' largest } \\
\text { shareholders (based on Business } \\
\text { Week classification of family } \\
\text { firms). }\end{array}$ & $\begin{array}{l}\text { Family firms are associated } \\
\text { with higher earnings quality } \\
\text { and have greater tendency to } \\
\text { warn for a given magnitude of } \\
\text { bad news. However, } \\
\text { disclosures relating to } \\
\text { corporate governance are } \\
\text { lower in those firms. }\end{array}$ \\
\hline $\begin{array}{l}\text { Ding, Zhang } \\
\text { and Zhang } \\
(2007)\end{array}$ & $\begin{array}{l}\text { To investigate the role } \\
\text { played by a firm's } \\
\text { ownership structure in } \\
\text { earnings management. }\end{array}$ & $\begin{array}{l}273 \text { privately- } \\
\text { owned and } \\
\text { state-owned } \\
\text { companies } \\
\text { listed in China } \\
\text { in } 2002 .\end{array}$ & $\begin{array}{l}\text { Earnings } \\
\text { management is } \\
\text { measured using } \\
\text { discretionary } \\
\text { accruals. }\end{array}$ & $\begin{array}{l}\text { Ownership concentration is } \\
\text { measured as the percentage of } \\
\text { shares held by the largest } \\
\text { shareholder over the total } \\
\text { shares. }\end{array}$ & $\begin{array}{l}\text { The relationship between } \\
\text { ownership concentration and } \\
\text { earnings management exhibits } \\
\text { an inverted U-shape pattern. } \\
\text { At low level, increased } \\
\text { ownership concentration is }\end{array}$ \\
\hline
\end{tabular}




\begin{tabular}{|c|c|c|c|c|c|}
\hline & & & & & $\begin{array}{l}\text { positively related to upward } \\
\text { earnings management, but at } \\
\text { higher level }(>55 \%) \text {, } \\
\text { ownership concentration is } \\
\text { associated with downward } \\
\text { earnings management. }\end{array}$ \\
\hline $\begin{array}{l}\text { Firth, Fung } \\
\text { and Rui (2007) }\end{array}$ & $\begin{array}{l}\text { To examine how ownership, } \\
\text { two-tier board structure, and } \\
\text { auditor affect firms' } \\
\text { earnings informativeness. }\end{array}$ & $\begin{array}{l}5189 \text { firm-year } \\
\text { observations } \\
\text { of } \\
\text { Chinese listed } \\
\text { companies, } \\
\text { over } 1998- \\
2003 \text {. }\end{array}$ & $\begin{array}{l}\text { Earnings } \\
\text { informativeness is } \\
\text { measured by earnings } \\
\text { response coefficients } \\
\text { and discretionary } \\
\text { accruals. }\end{array}$ & $\begin{array}{l}\text { The measure of ownership } \\
\text { concentration is based on the } \\
\text { percentage of shares owned by } \\
\text { the largest owner. }\end{array}$ & $\begin{array}{l}\text { The study shows that firms } \\
\text { with higher ownership } \\
\text { concentration have lower } \\
\text { earnings informativeness. This } \\
\text { result supports the } \\
\text { entrenchment effect that } \\
\text { concentrated ownership has on } \\
\text { earnings quality. }\end{array}$ \\
\hline $\begin{array}{l}\text { Hutchinson } \\
\text { and Leung } \\
(2007)\end{array}$ & $\begin{array}{l}\text { To examine the relationship } \\
\text { between top management } \\
\text { ownership and earnings } \\
\text { management. }\end{array}$ & $\begin{array}{l}15,945 \text { firm- } \\
\text { year } \\
\text { observations } \\
\text { of US firms } \\
\text { over 1996- } \\
2001 .\end{array}$ & $\begin{array}{l}\text { Earnings } \\
\text { management is } \\
\text { measured using } \\
\text { Kothari et.al (2005) } \\
\text { performance-adjusted } \\
\text { current discretionary } \\
\text { accruals. }\end{array}$ & $\begin{array}{l}\text { Top management ownership is } \\
\text { measures as the total stocks held } \\
\text { by directors and officers over } \\
\text { the total current outstanding } \\
\text { stocks. }\end{array}$ & $\begin{array}{l}\text { Top management ownership } \\
\text { is non-monotonically } \\
\text { associated with managers' } \\
\text { propensity to manage } \\
\text { earnings. }\end{array}$ \\
\hline $\begin{array}{l}\text { Jaggi and } \\
\text { Leung (2007) }\end{array}$ & $\begin{array}{l}\text { To examines whether the } \\
\text { establishment of audit } \\
\text { committees by Hong Kong } \\
\text { firms would constrain } \\
\text { earnings management, } \\
\text { especially in firms with } \\
\text { family-dominated corporate } \\
\text { boards. }\end{array}$ & $\begin{array}{l}523 \\
\text { observations } \\
\text { of Hong Kong } \\
\text { firms over the } \\
\text { period 1999- } \\
2000 .\end{array}$ & $\begin{array}{l}\text { Earnings } \\
\text { management } \\
\text { measured by } \\
\text { discretionary } \\
\text { accruals. }\end{array}$ & $\begin{array}{l}\text { Family firms are measured } \\
\text { using the proportion of directors } \\
\text { from the same family on the } \\
\text { board of directors. }\end{array}$ & $\begin{array}{l}\text { The effectiveness of audit } \\
\text { committees is, however, } \\
\text { significantly reduced when } \\
\text { family members are present on } \\
\text { corporate boards. }\end{array}$ \\
\hline $\begin{array}{l}\text { Sánchez, } \\
\text { Alemán and } \\
\text { Martín (2007) }\end{array}$ & $\begin{array}{l}\text { To analyze the relationship } \\
\text { between family control and } \\
\text { earnings quality in a context }\end{array}$ & $\begin{array}{l}102 \text { non } \\
\text { financial firms } \\
\text { listed on the }\end{array}$ & $\begin{array}{l}\text { Earnings } \\
\text { management } \\
\text { (absolute value of }\end{array}$ & $\begin{array}{l}\text { Family firms (FAMVAR) are } \\
\text { firms that have family shares of } \\
\text { more than } 10 \% \text { with at least a }\end{array}$ & $\begin{array}{l}\text { Family firms are more likely } \\
\text { to have higher quality of } \\
\text { earnings relative to non-family }\end{array}$ \\
\hline
\end{tabular}




\begin{tabular}{|c|c|c|c|c|c|}
\hline & $\begin{array}{l}\text { where there is a divergence } \\
\text { of interest between } \\
\text { controlling and minority } \\
\text { shareholders. }\end{array}$ & $\begin{array}{l}\text { Spanish stock } \\
\text { market } \\
\text { at the end of } \\
2003 \text {. }\end{array}$ & $\begin{array}{l}\text { discretionary } \\
\text { accruals) based on } \\
\text { Jones model } \\
\text { modified by Kothari } \\
\text { et al. (2005) and } \\
\text { predictability of cash } \\
\text { flows. }\end{array}$ & $\begin{array}{l}\text { family representative on board. } \\
\text { Family ownership (FAMOWN) } \\
\text { is measured as percentage of } \\
\text { voting rights held by the family } \\
\text { owners. Divergence between the } \\
\text { voting and cash flows rights of } \\
\text { family firms (FAMDIV) is } \\
\text { measured by the ratio of voting } \\
\text { rights over cash flow rights. }\end{array}$ & $\begin{array}{l}\text { firms. The study also found } \\
\text { that lower divergence between } \\
\text { voting and cash flows rights of } \\
\text { controlling family leads to } \\
\text { higher quality of earnings. }\end{array}$ \\
\hline $\begin{array}{l}\text { Kim and Yi } \\
(2006)\end{array}$ & $\begin{array}{l}\text { To investigate whether, and } \\
\text { how, the deviation of } \\
\text { controlling shareholders' } \\
\text { control from ownership, } \\
\text { business group affiliation, } \\
\text { and listing status } \\
\text { differentially affect the } \\
\text { extent of earnings } \\
\text { management. }\end{array}$ & $\begin{array}{l}15,159 \text { firm- } \\
\text { year } \\
\text { observations } \\
\text { of public and } \\
\text { private Korean } \\
\text { firms over the } \\
\text { period 1992- } \\
2000 \text {. }\end{array}$ & $\begin{array}{l}\text { Earnings } \\
\text { management is } \\
\text { measured by absolute } \\
\text { discretionary accruals } \\
\text { estimated from the } \\
\text { modified Jones } \\
\text { (1991) model. }\end{array}$ & $\begin{array}{l}\text { This study use a measure called } \\
\text { ownership wedge, which is a } \\
\text { continuous variable measuring } \\
\text { the difference between control } \\
\text { rights and cash flow rights held } \\
\text { by the controlling shareholder. }\end{array}$ & $\begin{array}{l}\text { The study found that as the } \\
\text { difference between control } \\
\text { (voting rights) and ownership } \\
\text { (cash now rights) of the } \\
\text { controlling shareholders } \\
\text { becomes larger, firms tend to } \\
\text { have a more aggressive } \\
\text { earnings management. }\end{array}$ \\
\hline $\begin{array}{l}\text { Velury and } \\
\text { Jenkins (2006) }\end{array}$ & $\begin{array}{l}\text { To investigate whether the } \\
\text { quality of reported earnings } \\
\text { is associated with the level } \\
\text { of institutional ownership } \\
\text { and ownership } \\
\text { concentration. }\end{array}$ & $\begin{array}{l}4238 \text { firm-year } \\
\text { observations } \\
\text { from CSRP } \\
\text { over 1992- } \\
1999 .\end{array}$ & $\begin{array}{l}\text { Predictive value or } \\
\text { feedback value, } \\
\text { neutrality, timeliness } \\
\text { and representational } \\
\text { faithfulness. }\end{array}$ & $\begin{array}{l}\text { Institutional ownership is } \\
\text { measured as the percentage of } \\
\text { common shares held by } \\
\text { institutions. Ownership } \\
\text { concentration is based on } \\
\text { percentage of company's stock } \\
\text { held by the five largest } \\
\text { institutional owners of the firm. }\end{array}$ & $\begin{array}{l}\text { Earnings quality is positively } \\
\text { associated with institutional } \\
\text { ownership, but negatively } \\
\text { associated with concentrated } \\
\text { institutional ownership. }\end{array}$ \\
\hline Wang (2006) & $\begin{array}{l}\text { To investigate the relation } \\
\text { between founding family } \\
\text { ownership and earnings } \\
\text { quality. }\end{array}$ & $\begin{array}{l}4195 \\
\text { observations } \\
\text { from S\&P } 500 \\
\text { companies for } \\
\text { the period } \\
1994-2002 .\end{array}$ & $\begin{array}{l}\text { Abnormal accruals, } \\
\text { earnings } \\
\text { informativeness, and } \\
\text { persistence of } \\
\text { transitory loss } \\
\text { components in } \\
\text { earnings. }\end{array}$ & $\begin{array}{l}\text { This study uses a dummy } \\
\text { variable for family founding } \\
\text { ownership. Firms that have the } \\
\text { founder owning some shares are } \\
\text { considered as having founding } \\
\text { family ownership. }\end{array}$ & $\begin{array}{l}\text { Founding family ownership is } \\
\text { associated with lower } \\
\text { abnormal accruals, greater } \\
\text { earnings informativeness, and } \\
\text { less persistence of transitory } \\
\text { loss components in earnings. }\end{array}$ \\
\hline
\end{tabular}




\begin{tabular}{|c|c|c|c|c|c|}
\hline Koh (2003) & $\begin{array}{l}\text { To examine the association } \\
\text { between institutional } \\
\text { ownership and aggressive } \\
\text { earnings management (EM) } \\
\text { strategies in Australia. }\end{array}$ & $\begin{array}{l}107 \text { firm-year } \\
\text { observations } \\
\text { of Australian } \\
\text { firms listed on } \\
\text { the ASX over } \\
\text { 1993-1997. }\end{array}$ & $\begin{array}{l}\text { Earnings } \\
\text { management is } \\
\text { measured by } \\
\text { discretionary accruals } \\
\text { from cross-sectional } \\
\text { variations of Jones } \\
\text { (1991) model. }\end{array}$ & $\begin{array}{l}\text { Institutional ownership is total } \\
\text { shares held by institutional } \\
\text { investors divided by firm's total } \\
\text { shares outstanding. }\end{array}$ & $\begin{array}{l}\text { Relationship between } \\
\text { institutional ownership and } \\
\text { EM is non-linear. } \\
\text { At lower level, higher portion } \\
\text { of institutional ownership is } \\
\text { related to higher EM. At } \\
\text { higher level, higher portion of } \\
\text { institutional ownership is } \\
\text { related to less EM. }\end{array}$ \\
\hline $\begin{array}{l}\text { Vander } \\
\text { Bauwhede, } \\
\text { Willekens \& } \\
\text { Gaeremynck } \\
(2003)\end{array}$ & $\begin{array}{l}\text { To investigate the impact of } \\
\text { income smoothing, auditor } \\
\text { size, and public ownership } \\
\text { on earnings management. }\end{array}$ & $\begin{array}{l}136 \text { firm-year } \\
\text { observations } \\
\text { of Belgian } \\
\text { matched- } \\
\text { sample } \\
\text { companies } \\
\text { over a 3-year } \\
\text { period. }\end{array}$ & $\begin{array}{l}\text { Earnings } \\
\text { management is } \\
\text { measured using } \\
\text { discretionary } \\
\text { accruals. }\end{array}$ & $\begin{array}{l}\text { Firms with public ownership are } \\
\text { those that are publicly listed. }\end{array}$ & $\begin{array}{l}\text { Both private and public firms } \\
\text { manage earnings to meet the } \\
\text { benchmark target of prior-year } \\
\text { earnings. Public companies } \\
\text { are more likely to manage } \\
\text { earnings only in above target } \\
\text { companies. }\end{array}$ \\
\hline $\begin{array}{l}\text { Fan and Wong } \\
(2002)\end{array}$ & $\begin{array}{l}\text { To examine the association } \\
\text { between earnings } \\
\text { informativeness and } \\
\text { ownership structure. }\end{array}$ & $\begin{array}{l}977 \text { firms from } \\
\text { Hong Kong, } \\
\text { Indonesia, } \\
\text { Malaysia, } \\
\text { Singapore, } \\
\text { South Korea, } \\
\text { Taiwan, and } \\
\text { Thailand. }\end{array}$ & $\begin{array}{l}\text { Earnings } \\
\text { informativeness is } \\
\text { based on returns- } \\
\text { earnings relationship. }\end{array}$ & $\begin{array}{l}\text { Ownership concentration is } \\
\text { measured based on the degree of } \\
\text { divergence between the } \\
\text { controlling owner's cash flow } \\
\text { rights and voting rights. }\end{array}$ & $\begin{array}{l}\text { Concentrated ownership is } \\
\text { associated with low } \\
\text { informativeness of earnings. }\end{array}$ \\
\hline $\begin{array}{l}\text { Gabrielsen, } \\
\text { Gramlich and } \\
\text { Plenborg } \\
(2002)\end{array}$ & $\begin{array}{l}\text { To examine the impact of } \\
\text { managerial ownership on the } \\
\text { information content of } \\
\text { earnings in Danish } \\
\text { companies. }\end{array}$ & $\begin{array}{l}76 \text { Danish } \\
\text { firms over } \\
1991-1995 .\end{array}$ & $\begin{array}{l}\text { Information content } \\
\text { of earnings is } \\
\text { measured based on } \\
\text { earnings response } \\
\text { coefficient and } \\
\text { discretionary } \\
\text { accruals. }\end{array}$ & $\begin{array}{l}\text { Managerial ownership is based } \\
\text { on the percentage of equity held } \\
\text { by individuals (officers, } \\
\text { directors and principal owners) } \\
\text { who can exercise significant } \\
\text { influence over corporate } \\
\text { matters. }\end{array}$ & $\begin{array}{l}\text { Managerial ownership is } \\
\text { negatively related to the } \\
\text { information content of } \\
\text { earnings. }\end{array}$ \\
\hline $\begin{array}{l}\text { Jung and } \\
\text { Kwon (2002) }\end{array}$ & $\begin{array}{l}\text { To examine the relationship } \\
\text { between corporate } \\
\text { ownership structure and }\end{array}$ & $\begin{array}{l}2820 \\
\text { observations } \\
\text { of firms listed }\end{array}$ & $\begin{array}{l}\text { Earnings } \\
\text { informativeness is } \\
\text { measured based on }\end{array}$ & $\begin{array}{l}\text { Ownership of largest } \\
\text { shareholders is measured using } \\
\text { a dichotomous variable, } 1 \text { if the }\end{array}$ & $\begin{array}{l}\text { The results support the } \\
\text { convergence of interest } \\
\text { hypothesis. The results show }\end{array}$ \\
\hline
\end{tabular}




\begin{tabular}{|c|c|c|c|c|c|}
\hline & earnings informativeness. & $\begin{array}{l}\text { on the Korean } \\
\text { Stock } \\
\text { Exchange over } \\
1993-1998 .\end{array}$ & $\begin{array}{l}\text { earnings-returns } \\
\text { relationship. }\end{array}$ & $\begin{array}{l}\text { largest shareholder's ownership } \\
\text { is higher than the median, } 0 \\
\text { otherwise. Similar method is } \\
\text { used for the measurement of } \\
\text { institutional shareholders. }\end{array}$ & $\begin{array}{l}\text { positive relationship between } \\
\text { earnings informativeness and } \\
\text { both, the owner-largest } \\
\text { shareholders and institutional } \\
\text { owners/ blockholders. }\end{array}$ \\
\hline $\begin{array}{l}\text { Ho and Wong } \\
(2001)\end{array}$ & $\begin{array}{l}\text { To study the relation of } \\
\text { independent directors, } \\
\text { voluntary audit committee, } \\
\text { dominant personalities } \\
\text { (CEO/Chairman duality), the } \\
\text { percentage of family } \\
\text { members on the board with } \\
\text { the extent of voluntary } \\
\text { disclosure. }\end{array}$ & $\begin{array}{l}98 \text { Hong Kong } \\
\text { companies } \\
\text { over } 1994- \\
1997 .\end{array}$ & $\begin{array}{l}\text { The quality of } \\
\text { accounting } \\
\text { information is } \\
\text { represented by } \\
\text { voluntary disclosure. }\end{array}$ & $\begin{array}{l}\text { Family ownership is based on } \\
\text { the percentage of family } \\
\text { members on board. }\end{array}$ & $\begin{array}{l}\text { The extent of voluntary } \\
\text { disclosure is positively related } \\
\text { to the presence of an audit } \\
\text { committee, and negatively } \\
\text { related to the percentage of } \\
\text { family members on the board. }\end{array}$ \\
\hline $\begin{array}{l}\text { Carlson and } \\
\text { Bathala (1997) }\end{array}$ & $\begin{array}{l}\text { To examine the association } \\
\text { between different ownership } \\
\text { structure and income } \\
\text { smoothing. }\end{array}$ & $\begin{array}{l}265 \text { firms from } \\
\text { Forbes. }\end{array}$ & $\begin{array}{l}\text { Income smoothing } \\
\text { based on variability } \\
\text { of income. }\end{array}$ & $\begin{array}{l}\text { Managerial ownership is based } \\
\text { on the proportion of stock } \\
\text { ownership held by insiders } \\
\text { (officers and directors). } \\
\text { Institutional ownership is } \\
\text { measured as the percentage of } \\
\text { outstanding common shares } \\
\text { held by institutional investors } \\
\text { and the number of institutional } \\
\text { investors holding the firm's } \\
\text { common stock. }\end{array}$ & $\begin{array}{l}\text { The study found that firms } \\
\text { that smooth income (1) have } \\
\text { lower proportion of inside } \\
\text { ownership (2) higher } \\
\text { proportions of institutional } \\
\text { ownership (3) wider the } \\
\text { dispersion of stock ownership. }\end{array}$ \\
\hline $\begin{array}{l}\text { Warfield, Wild } \\
\text { \& Wild (1995) }\end{array}$ & $\begin{array}{l}\text { To study how the separation } \\
\text { of corporate ownership and } \\
\text { control affects both the } \\
\text { informativeness of earnings } \\
\text { and the managers' } \\
\text { accounting choices. }\end{array}$ & $\begin{array}{l}4,778 \text { firm- } \\
\text { year } \\
\text { observations }\end{array}$ & $\begin{array}{l}\text { Informativeness of } \\
\text { earnings is based on } \\
\text { earnings-returns } \\
\text { relationship and } \\
\text { managers accounting } \\
\text { choices is based on } \\
\text { discretionary } \\
\text { accruals. }\end{array}$ & $\begin{array}{l}\text { Percentage of managerial } \\
\text { ownership. }\end{array}$ & $\begin{array}{l}\text { Managerial ownership is } \\
\text { positively associated with } \\
\text { earnings explanatory power } \\
\text { for returns and negatively } \\
\text { related to the magnitude of } \\
\text { accrual adjustments. }\end{array}$ \\
\hline
\end{tabular}




\begin{tabular}{|c|c|c|c|c|c|}
\hline $\begin{array}{l}\text { Dempsey, } \\
\text { Hunt III and } \\
\text { Shcroeder } \\
\text { (1993) }\end{array}$ & $\begin{array}{l}\text { To examine the relation } \\
\text { between ownership structure } \\
\text { and earnings management } \\
\text { through the use of } \\
\text { extraordinary item (EI) } \\
\text { reporting. }\end{array}$ & $\begin{array}{l}248 \text { firms from } \\
\text { COMPUSTAT } \\
\text { that reported at } \\
\text { least one EI } \\
\text { during 1960- } \\
1966 .\end{array}$ & $\begin{array}{l}\text { Earnings } \\
\text { management is based } \\
\text { on the tendency to } \\
\text { report extraordinary } \\
\text { gains in income } \\
\text { statement and } \\
\text { extraordinary losses } \\
\text { in retained earnings } \\
\text { statement. }\end{array}$ & $\begin{array}{l}\text { Firms are divided into (1) } \\
\text { owner-managed (firms with a } \\
\text { CEO who owns five percent or } \\
\text { more of voting shares),(2) } \\
\text { externally-controlled (firms } \\
\text { with a dominant stockholder } \\
\text { with interest of } 10 \text { percent or } \\
\text { more and not part of top } \\
\text { management), and manager- } \\
\text { controlled (firms which do not } \\
\text { meet the definition of OM or } \\
\text { EC firms). }\end{array}$ & $\begin{array}{l}\text { Non-owner managers select } \\
\text { income-increasing reporting } \\
\text { alternatives for EIs more often } \\
\text { than owner-managers. }\end{array}$ \\
\hline
\end{tabular}




\section{Appendix 4: Empirical Studies of the Corporate Governance and Earnings Quality Relation ${ }^{28}$}

\begin{tabular}{|c|c|c|c|c|c|}
\hline Author(s) & Research objective & Sample & $\begin{array}{l}\text { Measures for Earnings } \\
\text { Quality }\end{array}$ & $\begin{array}{l}\text { Corporate Governance } \\
\text { Variables }\end{array}$ & Results \\
\hline $\begin{array}{l}\text { Labelle, } \\
\text { Gargouri and } \\
\text { Francoeur } \\
(2010)\end{array}$ & $\begin{array}{l}\text { To study the relation } \\
\text { between corporate } \\
\text { governance, business ethics } \\
\text { and financial reporting } \\
\text { quality. }\end{array}$ & $\begin{array}{l}156 \\
\text { observations of } \\
78 \text { companies } \\
\text { over } 2 \text { years } \\
(2005-2006) .\end{array}$ & $\begin{array}{l}\text { Earnings management is } \\
\text { used as a proxy for } \\
\text { earnings quality. A } \\
\text { dummy is use to indicate } \\
\text { earnings management. } \\
\text { Firms with absolute } \\
\text { value of discretionary } \\
\text { that falls above the } \\
\text { median is categorized as } \\
\text { having higher earnings } \\
\text { management, vice versa. }\end{array}$ & $\begin{array}{l}\text { Governance quality is } \\
\text { measured using the ratings } \\
\text { of Jantzi Research (JR), a } \\
\text { leading provider of social } \\
\text { and governance research } \\
\text { for institutional investors. }\end{array}$ & $\begin{array}{l}\text { There is a significant negative } \\
\text { relation between business } \\
\text { ethics and the magnitude of } \\
\text { earnings management, while } \\
\text { controlling for corporate } \\
\text { governance and other factors. }\end{array}$ \\
\hline $\begin{array}{l}\text { Teitel and } \\
\text { Machiga } \\
(2010)\end{array}$ & $\begin{array}{l}\text { To examine the interaction } \\
\text { effect of auditor quality on } \\
\text { the association between } \\
\text { earnings quality and the } \\
\text { implementation of the } \\
\text { Mexican code of best } \\
\text { corporate practices. }\end{array}$ & $\begin{array}{l}44 \text { firms listed } \\
\text { on the Mexican } \\
\text { Stock } \\
\text { Exchange } \\
\text { (Bolsa), 1998- } \\
2002 \text {. }\end{array}$ & $\begin{array}{l}\text { Income smoothing, } \\
\text { measured by the ratio of } \\
\text { the variability of the } \\
\text { absolute value of the } \\
\text { changes in NI to CFO, } \\
\text { and the spearman } \\
\text { correlation of total } \\
\text { accruals with CFO; and } \\
\text { conditional accrual. }\end{array}$ & $\begin{array}{l}\text { Auditor quality (Big5/non- } \\
\text { Big5) }\end{array}$ & $\begin{array}{l}\text { Firms that hire high quality } \\
\text { auditors are more likely to } \\
\text { have greater earnings quality } \\
\text { after the implementation of the } \\
\text { Mexican code of best } \\
\text { corporate practices. }\end{array}$ \\
\hline $\begin{array}{l}\text { Baxter and } \\
\text { Cotter (2009) }\end{array}$ & $\begin{array}{l}\text { To examine the association } \\
\text { between audit committees } \\
\text { and earnings in Australia. }\end{array}$ & $\begin{array}{l}309 \text { companies } \\
\text { from the Top } \\
500 \text { ASX listed } \\
\text { companies in } \\
2001 .\end{array}$ & $\begin{array}{l}\text { Earnings management } \\
\text { (Jones model) and } \\
\text { accrual estimation error } \\
\text { (Dechow and Dichev } \\
\text { model) }\end{array}$ & $\begin{array}{l}\text { Audit committee formation, } \\
\text { audit committees } \\
\text { independence, audit } \\
\text { committee expertise, audit } \\
\text { committee activity, audit } \\
\text { committee size. }\end{array}$ & $\begin{array}{l}\text { Audit committees are effective } \\
\text { in reducing intentional } \\
\text { earnings manipulations, but } \\
\text { not accrual estimation errors. }\end{array}$ \\
\hline
\end{tabular}

\footnotetext{
${ }^{28}$ While there are other studies examining earnings management and corporate governance, I include only studies that refer earnings management as a proxy for earnings quality.
The studies are presented in chronological and alphabetical order.
} 


\begin{tabular}{|c|c|c|c|c|c|}
\hline Author(s) & Research objective & Sample & $\begin{array}{l}\text { Measures for Earnings } \\
\text { Quality }\end{array}$ & $\begin{array}{l}\text { Corporate Governance } \\
\text { Variables }\end{array}$ & Results \\
\hline $\begin{array}{l}\text { Chang and } \\
\text { Sun (2009) }\end{array}$ & $\begin{array}{l}\text { To examine whether the } \\
\text { provisions of SOX improve } \\
\text { the effectiveness of an } \\
\text { independent audit committee } \\
\text { and other corporate- } \\
\text { governance functions in } \\
\text { monitoring the earnings } \\
\text { quality of cross-listed } \\
\text { foreign firms. }\end{array}$ & $\begin{array}{l}96 \text { foreign } \\
\text { firms in the } \\
\text { pre-SOX } \\
\text { sample and } 106 \\
\text { foreign firms in } \\
\text { the post-SOX } \\
\text { sample, over } \\
\text { the } 2001-2003 \\
\text { period. }\end{array}$ & $\begin{array}{l}\text { Earnings informativeness } \\
\text { and earnings } \\
\text { management. }\end{array}$ & $\begin{array}{l}\text { Audit committee } \\
\text { independence, board } \\
\text { independence, audit } \\
\text { committee financial expert, } \\
\text { CEO duality and an } \\
\text { aggregate corporate } \\
\text { governance score. }\end{array}$ & $\begin{array}{l}\text { After the SOX period, } \\
\text { earnings informativeness is } \\
\text { positively associated with } \\
\text { audit-committee } \\
\text { independence, board } \\
\text { independence and negatively } \\
\text { associated with CEO duality; } \\
\text { and earnings management is } \\
\text { negatively associated audit- } \\
\text { committee independence,. } \\
\text { However, no significant } \\
\text { associations were found in } \\
\text { pre-SOX period. The results } \\
\text { suggest that the SOX } \\
\text { provisions improve the } \\
\text { effectiveness corporate- } \\
\text { governance monitoring the } \\
\text { quality of earnings. }\end{array}$ \\
\hline $\begin{array}{l}\text { Gul, Fung and } \\
\text { Jaggi (2009) }\end{array}$ & $\begin{array}{l}\text { To examine whether } \\
\text { industry specialization of } \\
\text { auditors and low balling } \\
\text { affect the association } \\
\text { between auditor tenure and } \\
\text { earnings quality. }\end{array}$ & $\begin{array}{l}32,777 \text { firm- } \\
\text { year } \\
\text { observations of } \\
\text { over 1993-2004 } \\
\text { from the } \\
\text { Compustat. }\end{array}$ & Discretionary accruals. & $\begin{array}{l}\text { Auditor tenure and auditor } \\
\text { specialization. }\end{array}$ & $\begin{array}{l}\text { The association between } \\
\text { shorter auditor tenure and } \\
\text { lower earnings quality is } \\
\text { weaker for firms audited by } \\
\text { industry specialists compared } \\
\text { to non-specialists }\end{array}$ \\
\hline $\begin{array}{l}\text { Hashim and } \\
\text { Devi (2009) }\end{array}$ & $\begin{array}{l}\text { To examine the relationship } \\
\text { between board } \\
\text { characteristics and } \\
\text { ownership structure with } \\
\text { earnings quality. }\end{array}$ & $\begin{array}{l}280 \text { non- } \\
\text { financial } \\
\text { companies } \\
\text { listed on Bursa } \\
\text { Malaysia's } \\
\text { Main Board in } \\
2004 \text {. }\end{array}$ & Accrual quality. & $\begin{array}{l}\text { Board independence, CEO } \\
\text { duality, board size, board } \\
\text { meeting and board tenure }\end{array}$ & $\begin{array}{l}\text { Board tenure, outside board } \\
\text { ownership and family } \\
\text { ownership is positively } \\
\text { associated with earnings } \\
\text { quality. }\end{array}$ \\
\hline
\end{tabular}




\begin{tabular}{|c|c|c|c|c|c|}
\hline $\begin{array}{l}\text { Machuga and } \\
\text { Teitel (2009) }\end{array}$ & $\begin{array}{l}\text { To investigate whether } \\
\text { board characteristics (board } \\
\text { composition disclosure, } \\
\text { family concentrated } \\
\text { ownership and shared- } \\
\text { directors) are associated } \\
\text { with the improvement in } \\
\text { earnings quality. }\end{array}$ & $\begin{array}{l}32 \text { companies } \\
\text { registered on } \\
\text { Mexican Stock } \\
\text { Exchange } \\
\text { (Mexican } \\
\text { Bolsa) over the } \\
\text { period 1998- } \\
2002 \text {. }\end{array}$ & $\begin{array}{l}\text { Income smoothing, } \\
\text { timely loss recognition } \\
\text { and conditional accruals. }\end{array}$ & $\begin{array}{l}\text { Board composition } \\
\text { disclosure, family } \\
\text { concentrated ownership } \\
\text { and shared-directors. }\end{array}$ & $\begin{array}{l}\text { Firms that do not have } \\
\text { concentrated family ownership } \\
\text { or share directors have greater } \\
\text { increases in earnings quality } \\
\text { than firms that have } \\
\text { concentrated family ownership } \\
\text { or share directors. }\end{array}$ \\
\hline $\begin{array}{l}\text { Pergola, } \\
\text { Joseph and } \\
\text { Jenzarli (2009) }\end{array}$ & $\begin{array}{l}\text { To study the association } \\
\text { between board members } \\
\text { ownership and earnings } \\
\text { quality. }\end{array}$ & $\begin{array}{l}499 \text { publicly } \\
\text { traded firms } \\
\text { from the S\&P } \\
500 \text { (large cap), } \\
\text { S\&P } 400 \text { (mid } \\
\text { cap), and S\&P } \\
600 \text { (small cap) } \\
\text { indices, in } \\
2002 .\end{array}$ & $\begin{array}{l}\text { Dechow and Dichev } \\
\text { (2002) accrual quality } \\
\text { model. }\end{array}$ & Board insider ownership, & $\begin{array}{l}\text { Earnings quality is negatively } \\
\text { associated with insider } \\
\text { ownership and the association } \\
\text { is moderated by governance } \\
\text { structures. }\end{array}$ \\
\hline $\begin{array}{l}\text { Rainsbury, } \\
\text { Bradbury and } \\
\text { Cahan (2009) }\end{array}$ & $\begin{array}{l}\text { To examine the association } \\
\text { between the quality of audit } \\
\text { committees on financial } \\
\text { reporting quality and } \\
\text { external audit fees in an } \\
\text { environment where the } \\
\text { formation of audit } \\
\text { committees was unregulated. }\end{array}$ & $\begin{array}{l}87 \text { New } \\
\text { Zealand firms } \\
\text { in } 2001 .\end{array}$ & $\begin{array}{l}\text { Financial reporting } \\
\text { quality score based on } \\
\text { firm's individual } \\
\text { accounting choice scores. }\end{array}$ & $\begin{array}{l}\text { Best practice of audit } \\
\text { committee, audit committee } \\
\text { independence, audit } \\
\text { committee expertise. }\end{array}$ & $\begin{array}{l}\text { There is no significant } \\
\text { association between the } \\
\text { quality of an audit committee } \\
\text { and the quality of financial } \\
\text { reporting. }\end{array}$ \\
\hline Flynn (2008) & $\begin{array}{l}\text { To examine the impact of } \\
\text { audit committee } \\
\text { compensation type on } \\
\text { nonprofessional investors' } \\
\text { perceptions of earnings } \\
\text { quality. }\end{array}$ & $\begin{array}{l}48 \\
\text { nonprofessional } \\
\text { investors. }\end{array}$ & $\begin{array}{l}\text { Earnings quality is based } \\
\text { on investors' perception, } \\
\text { gathered from an } \\
\text { experimental setting. }\end{array}$ & $\begin{array}{l}\text { Audit committee } \\
\text { compensation. }\end{array}$ & $\begin{array}{l}\text { Firms that compensate audit } \\
\text { committee based on stock } \\
\text { performance are more likely to } \\
\text { have lower perceived earnings } \\
\text { quality. }\end{array}$ \\
\hline
\end{tabular}




\begin{tabular}{|c|c|c|c|c|c|}
\hline $\begin{array}{l}\text { Francis, } \\
\text { Huang, } \\
\text { Rajopal and } \\
\text { Zhang (2008) }\end{array}$ & $\begin{array}{l}\text { To provide evidence on } \\
\text { whether reputed CEOs are } \\
\text { associated with higher or } \\
\text { lower quality of earnings }\end{array}$ & $\begin{array}{l}2000 \text { firm-year } \\
\text { observations } \\
\text { for S\&P } 500 \\
\text { firms over } \\
1992-2001 .\end{array}$ & Accrual quality. & CEO reputation. & $\begin{array}{l}\text { CEO with higher reputation is } \\
\text { associated with poorer } \\
\text { earnings quality. }\end{array}$ \\
\hline $\begin{array}{l}\text { Francis and } \\
\text { Wang (2008) }\end{array}$ & $\begin{array}{l}\text { To examine whether } \\
\text { earnings quality is jointly } \\
\text { affected by the investor } \\
\text { protection environment } \\
\text { where a firm is located and } \\
\text { the firm's choice of a Big } 4 \\
\text { versus non-Big } 4 \text { auditor. }\end{array}$ & $\begin{array}{l}57996 \text { obs. for } \\
\text { abnormal } \\
\text { accrual } \\
\text { analysis, } 85193 \\
\text { obs. for loss } \\
\text { avoidance, and } \\
68167 \text { obs. for } \\
\text { earnings } \\
\text { conservatism } \\
\text { from } 42 \\
\text { countries, } \\
\text { 1994-2004. }\end{array}$ & $\begin{array}{l}\text { Magnitude of signed } \\
\text { abnormal accruals } \\
\text { (Frankel, Johnson and } \\
\text { Nelson 2002), likelihood } \\
\text { of reporting a loss } \\
\text { (Burgstahler and Dichev } \\
\text { 1997) and earnings } \\
\text { conservatism (Basu } 1997 \\
\text { and Ball, Kothari, and } \\
\text { Robin 2000). }\end{array}$ & $\begin{array}{l}\text { Audit quality (Big4/Non- } \\
\text { Big4) }\end{array}$ & $\begin{array}{l}\text { Earnings quality is higher as } \\
\text { the country's investor } \\
\text { protection regime becomes } \\
\text { stronger, but only for firms } \\
\text { with Big } 4 \text { auditors. }\end{array}$ \\
\hline $\begin{array}{l}\text { Haber and } \\
\text { Braunstein } \\
(2008)\end{array}$ & $\begin{array}{l}\text { To see whether earnings } \\
\text { quality ratings correlate to } \\
\text { governance ratings. }\end{array}$ & $\begin{array}{l}50 \text { companies } \\
\text { listed on the } \\
\text { NYSE or } \\
\text { American } \\
\text { Exchange. }\end{array}$ & $\begin{array}{l}\text { Earnings quality ratings } \\
\text { are provided by 3D } \\
\text { Ratings according to } \\
\text { accounting principle } \\
\text { based models. }\end{array}$ & $\begin{array}{l}\text { GMI corporate governance } \\
\text { ratings. }\end{array}$ & $\begin{array}{l}\text { There is no significant } \\
\text { relationship between the } \\
\text { governance ratings of GMI } \\
\text { and earnings quality ratings of } \\
\text { 3D Ratings. }\end{array}$ \\
\hline $\begin{array}{l}\text { Jiang, Lee and } \\
\text { Anandarajan } \\
(2008)\end{array}$ & $\begin{array}{l}\text { To reexamines the relation } \\
\text { between corporate } \\
\text { governance and quality of } \\
\text { earnings using a summary } \\
\text { governance measure. }\end{array}$ & $\begin{array}{l}4,311 \\
\text { observations } \\
\text { over 2002- } \\
2004 .\end{array}$ & $\begin{array}{l}\text { Absolute discretionary } \\
\text { accruals and earnings } \\
\text { benchmark/ earnings } \\
\text { surprise. }\end{array}$ & $\begin{array}{l}\text { Gov-Score developed by } \\
\text { Brown and Caylor (2006). }\end{array}$ & $\begin{array}{l}\text { Higher levels of corporate } \\
\text { governance are associated } \\
\text { with lower absolute } \\
\text { discretionary accruals. } \\
\text { Corporate governance is also } \\
\text { negatively associated with } \\
\text { small earnings surprises. }\end{array}$ \\
\hline $\begin{array}{l}\text { Jaggi and } \\
\text { Leung (2007) }\end{array}$ & $\begin{array}{l}\text { To examines whether the } \\
\text { establishment of audit } \\
\text { committees by Hong Kong } \\
\text { firms would constrain } \\
\text { earnings management, } \\
\text { especially in firms with }\end{array}$ & $\begin{array}{l}523 \\
\text { observations of } \\
\text { Hong Kong } \\
\text { firms for the } \\
\text { period of 1999- } \\
2000 \text {. }\end{array}$ & $\begin{array}{l}\text { Earnings management } \\
\text { (magnitude of } \\
\text { discretionary accruals) }\end{array}$ & Audit committee. & $\begin{array}{l}\text { Audit committees play a } \\
\text { significant role in constraining } \\
\text { earnings management even in } \\
\text { the environment of higher } \\
\text { ownership concentration. But, } \\
\text { the effectiveness of audit }\end{array}$ \\
\hline
\end{tabular}




\begin{tabular}{|c|c|c|c|c|c|}
\hline & $\begin{array}{l}\text { family-dominated corporate } \\
\text { boards. }\end{array}$ & & & & $\begin{array}{l}\text { committees is significantly } \\
\text { reduced when family members } \\
\text { are present on boards. }\end{array}$ \\
\hline $\begin{array}{l}\text { García Lara, } \\
\text { García Osma } \\
\text { and Penalva } \\
(2007)\end{array}$ & $\begin{array}{l}\text { To examine whether firms } \\
\text { with low CEO influence on } \\
\text { board decision making } \\
\text { (indicating strong corporate } \\
\text { governance) are more } \\
\text { conservative than firms } \\
\text { where the CEO has a high } \\
\text { influence on board decision } \\
\text { making (weak governance } \\
\text { structure). }\end{array}$ & $\begin{array}{l}\text { 69 Spanish } \\
\text { listed firms for } \\
\text { the period } \\
1997-2002 \text {. }\end{array}$ & $\begin{array}{l}\text { Earnings conservatism } \\
\text { based on asymmetric } \\
\text { recognition speed of } \\
\text { good and bad news in } \\
\text { earnings, using Basu } \\
\text { (1997) and Ball and } \\
\text { Shivakumar (2005). }\end{array}$ & $\begin{array}{l}\text { Aggregate measures (Ind6 } \\
\text { and Ind8) of corporate } \\
\text { governance based on board } \\
\text { size, proportion of non- } \\
\text { executive directors, } \\
\text { proportion of independent } \\
\text { directors, whether the } \\
\text { chairman of the board is an } \\
\text { executive director, the } \\
\text { number of board meetings, } \\
\text { and the existence of an } \\
\text { audit committee, a } \\
\text { nomination/ remuneration } \\
\text { committee and an executive } \\
\text { committee. }\end{array}$ & $\begin{array}{l}\text { Firms with a CEO that has a } \\
\text { low influence over the } \\
\text { functioning of the board of } \\
\text { directors show a greater } \\
\text { degree of accounting } \\
\text { conservatism. }\end{array}$ \\
\hline $\begin{array}{l}\text { Machuga and } \\
\text { Teitel (2007) }\end{array}$ & $\begin{array}{l}\text { To investigate whether there } \\
\text { is an improvement in } \\
\text { earnings quality after the } \\
\text { implementation of the code } \\
\text { of corporate governance in } \\
\text { Mexico. }\end{array}$ & $\begin{array}{l}92 \text { Mexican } \\
\text { firms during } \\
1998-2002 .\end{array}$ & $\begin{array}{l}\text { Income smoothing, } \\
\text { timely loss recognition, } \\
\text { abnormal accruals. }\end{array}$ & $\begin{array}{l}\text { Implementation of the } \\
\text { Mexican code of corporate } \\
\text { governance. }\end{array}$ & $\begin{array}{l}\text { The quality of earnings } \\
\text { increases after the } \\
\text { implementation of the Code. }\end{array}$ \\
\hline Petra (2007) & $\begin{array}{l}\text { To examine whether the } \\
\text { informativeness of earnings } \\
\text { is associated with corporate } \\
\text { governance. }\end{array}$ & $\begin{array}{l}\text { 500 largest US } \\
\text { publicly listed } \\
\text { firms, over } \\
1996-1999 .\end{array}$ & $\begin{array}{l}\text { Earnings response } \\
\text { coefficient }\end{array}$ & $\begin{array}{l}\text { Percentage of outside } \\
\text { independent directors } \\
\text { serving on the board, the } \\
\text { absence of CEO duality, } \\
\text { the presence of independent } \\
\text { audit committee, } \\
\text { compensation committee, } \\
\text { and nominating committee. }\end{array}$ & $\begin{array}{l}\text { The proportion of outside } \\
\text { independent directors serving } \\
\text { on firm's boards is positively } \\
\text { associated with earnings } \\
\text { informativeness. }\end{array}$ \\
\hline
\end{tabular}




\begin{tabular}{|c|c|c|c|c|c|}
\hline $\begin{array}{l}\text { Lin, Li and } \\
\text { Yang (2006) }\end{array}$ & $\begin{array}{l}\text { To investigate the effect of } \\
\text { audit committee } \\
\text { performance on earnings } \\
\text { quality. }\end{array}$ & $\begin{array}{l}212 \text { publicly } \\
\text { listed US } \\
\text { companies that } \\
\text { restated their } \\
\text { earnings in the } \\
\text { year } 2000 .\end{array}$ & Restatement of earnings. & $\begin{array}{l}\text { Size of audit committee, } \\
\text { audit committee } \\
\text { independence, audit } \\
\text { committee financial } \\
\text { expertise, frequency of } \\
\text { audit committee meetings } \\
\text { and audit committee } \\
\text { members ownership }\end{array}$ & $\begin{array}{l}\text { The study found a negative } \\
\text { association between the size of } \\
\text { audit committee and earnings } \\
\text { quality. They found no } \\
\text { evidence on the relationship } \\
\text { between four other audit } \\
\text { committee characteristics } \\
\text { (independence, financial } \\
\text { expertise, frequency of } \\
\text { meetings and ownership) and } \\
\text { earnings restatement. }\end{array}$ \\
\hline Vafeas (2005) & $\begin{array}{l}\text { To study the relationship } \\
\text { between audit committees } \\
\text { and boards of directors with } \\
\text { earnings quality. }\end{array}$ & $\begin{array}{l}252 \text { U.S. firms, } \\
\text { from } 1994 \text { to } \\
2000 .\end{array}$ & $\begin{array}{l}\text { The magnitude of } \\
\text { earnings increases (small } \\
\text { earnings increases } \\
\text { indicates low quality of } \\
\text { earnings) and negative } \\
\text { earnings avoidance. }\end{array}$ & $\begin{array}{l}\text { Percentage of committee } \\
\text { insiders, percentage of } \\
\text { active business executives, } \\
\text { percentage of members } \\
\text { with other audit committee } \\
\text { experience, audit } \\
\text { committee size, audit } \\
\text { committee meetings, stock } \\
\text { ownership of committee } \\
\text { members, mean tenure per } \\
\text { committee member, mean } \\
\text { directorships per committee } \\
\text { member, mean committee } \\
\text { memberships per } \\
\text { committee member, inside } \\
\text { ownership, percentage of } \\
\text { board outsiders, and board } \\
\text { size. }\end{array}$ & $\begin{array}{l}\text { Firms with greater insider in } \\
\text { audit committee, less active } \\
\text { business executive, less } \\
\text { frequency of meeting, higher } \\
\text { equity incentives and greater } \\
\text { length of board tenure are } \\
\text { more likely to have lower } \\
\text { quality of earnings. }\end{array}$ \\
\hline Wild (1996) & $\begin{array}{l}\text { To examine the association } \\
\text { between audit committee } \\
\text { formation and earnings } \\
\text { quality. }\end{array}$ & $\begin{array}{l}260 \text { listed firms } \\
\text { in the U.S., } \\
\text { over 1966- } \\
1980 .\end{array}$ & $\begin{array}{l}\text { Earnings Response } \\
\text { Coefficient (ERC). }\end{array}$ & Audit committee formation & $\begin{array}{l}\text { The result shows a significant } \\
\text { increase in the market's } \\
\text { reaction to earnings } \\
\text { subsequent to the formation of } \\
\text { the audit committee. This } \\
\text { suggests that audit committee }\end{array}$ \\
\hline
\end{tabular}




\begin{tabular}{|l|l|l|l|l|l|}
\hline & & & & $\begin{array}{l}\text { improve earnings quality } \\
\text { through their effective } \\
\text { monitoring of the financial } \\
\text { reporting and auditing } \\
\text { process. }\end{array}$ \\
\hline
\end{tabular}




\section{Appendix 5: Ticker Code Used to Extract Financial Data from Thompson Financial One Banker Database.}

\begin{tabular}{|c|c|c|c|}
\hline Variables & Description & Worldscope Item Name and Ticker Code & Thompson Financial Definition of Variables \\
\hline TCA & $\begin{array}{l}\text { Total current accrual is measured as } \\
\text { changes in working capital. }\end{array}$ & $\begin{array}{l}\text { Increase/Decrease In Working Capital } \\
\text { Ws.WorkingCapitalIncDecCFStmt }\end{array}$ & $\begin{array}{l}\text { The change in working capital from one year to } \\
\text { the next year }\end{array}$ \\
\hline TASSETS & Total Assets & $\begin{array}{l}\text { Total Assets } \\
\text { Ws.TotalAssets }\end{array}$ & $\begin{array}{l}\text { The sum of total current assets, long term } \\
\text { receivables, investment in unconsolidated } \\
\text { subsidiaries, other investments, net property } \\
\text { plant and equipment and other assets. }\end{array}$ \\
\hline $\mathrm{CFO}$ & Cash flow from operations & $\begin{array}{l}\text { Net Cash Flow - Operating Activities } \\
\text { Ws.NetCashFlowOperatingCFStmt }\end{array}$ & $\begin{array}{l}\text { The net cash receipts and disbursements } \\
\text { resulting from the operations of the company. It } \\
\text { is the sum of Funds from Operations, Funds } \\
\text { From/Used for Other Operating Activities and } \\
\text { Extraordinary Items. }\end{array}$ \\
\hline PPE & Gross plant, property and equipment & $\begin{array}{l}\text { Property, Plant and Equipment- Gross } \\
\text { Ws.TotalPropPlantEquipGross }\end{array}$ & $\begin{array}{l}\text { Tangible assets with an expected useful life of } \\
\text { over one year which are expected to be used to } \\
\text { produce goods for sale or for distribution of } \\
\text { services. }\end{array}$ \\
\hline REV & Revenues / Sales & $\begin{array}{l}\text { Net Sales or Revenues } \\
\text { Ws.Sales }\end{array}$ & $\begin{array}{l}\text { Gross sales and other operating revenue less } \\
\text { discounts, returns and allowances. }\end{array}$ \\
\hline NI & Net Income & $\begin{array}{l}\text { Net Income Used To Calculate Earnings Per } \\
\text { Share (Formerly Net Income Available To } \\
\text { Common) } \\
\text { Ws.NetIncome }\end{array}$ & $\begin{array}{l}\text { The net income the company uses to calculate } \\
\text { its earnings per share. It is before extraordinary } \\
\text { items. }\end{array}$ \\
\hline WCAPITAL & Working Capital & $\begin{array}{l}\text { Working Capital } \\
\text { Ws.WorkingCapBalSht }\end{array}$ & $\begin{array}{l}\text { The difference between current assets and } \\
\text { current liabilities. }\end{array}$ \\
\hline
\end{tabular}




\begin{tabular}{|c|c|c|c|}
\hline RETEARN & Retained Earnings & $\begin{array}{l}\text { Retained Earnings } \\
\text { Ws.RetainedEarnings }\end{array}$ & $\begin{array}{l}\text { The accumulated after tax earnings of the } \\
\text { company which have not been distributed as } \\
\text { dividends to shareholders or allocated to a } \\
\text { reserve account. }\end{array}$ \\
\hline EBIT & Earnings Before Interest and Taxes & $\begin{array}{l}\text { Earnings Before Interest And Taxes (EBIT) } \\
\text { Ws.EarningsBeforeInterestAndTaxes }\end{array}$ & $\begin{array}{l}\text { The earnings of a company before interest } \\
\text { expense and income taxes. It is calculated by } \\
\text { taking the pretax income and adding back } \\
\text { interest expense on debt and subtracting interest } \\
\text { capitalized. }\end{array}$ \\
\hline MKTCAP & Market Capitalisation & $\begin{array}{l}\text { Market Capitalisation } \\
\text { Ws.YrEndMarketCap }\end{array}$ & $\begin{array}{l}\text { Market Price-Year End } * \text { Common Shares } \\
\text { Outstanding }\end{array}$ \\
\hline GROWTH & Price to Book Ratio & $\begin{array}{l}\text { Price/Book Value Ratio - Close } \\
\text { Ws.PriceToBookRatioClose }\end{array}$ & $\begin{array}{l}\text { Market Price at financial year end divide by } \\
\text { Book Value Per Share }\end{array}$ \\
\hline LEVERAGE & $\begin{array}{l}\text { Percentage of Total Debt over Total } \\
\text { Assets }\end{array}$ & $\begin{array}{l}\text { Total Debt \% Total Assets } \\
\text { Ws.TotalDebtPctTotalAssets }\end{array}$ & $\begin{array}{l}\text { (Short Term Debt \& Current Portion of Long } \\
\text { Term Debt }+ \text { Long Term Debt) / Total Assets * } \\
100\end{array}$ \\
\hline PPENET & Net Plant, Property and Equipment & $\begin{array}{l}\text { Property, plant and equipment- Net } \\
\text { Ws.TotalPropPlantEquipNet }\end{array}$ & $\begin{array}{l}\text { Gross Property, Plant and Equipment less } \\
\text { accumulated reserves for depreciation, depletion } \\
\text { and amortization. }\end{array}$ \\
\hline OCYCLE & Operating Cycle & $\begin{array}{l}\text { Operating Cycle } \\
\text { Ws.OperatingCycle }\end{array}$ & InventoriesDaysHeld+AccountsReceivableDays \\
\hline RNDSALES & $\begin{array}{l}\text { Ratio of research and development } \\
\text { to sales }\end{array}$ & $\begin{array}{l}\text { Research and Development/Sales } \\
\text { Ws.ResearchAndDevelopmentToSales }\end{array}$ & $\begin{array}{l}\text { Research and Development Expense / Net Sales } \\
\text { or Revenues * } 100\end{array}$ \\
\hline
\end{tabular}

